Prepared in cooperation with the North Plains Groundwater Conservation District

\title{
Water Quality of the Ogallala Formation, Central High Plains Aquifer Within the North Plains Groundwater Conservation District, Texas Panhandle, 2012-13
}

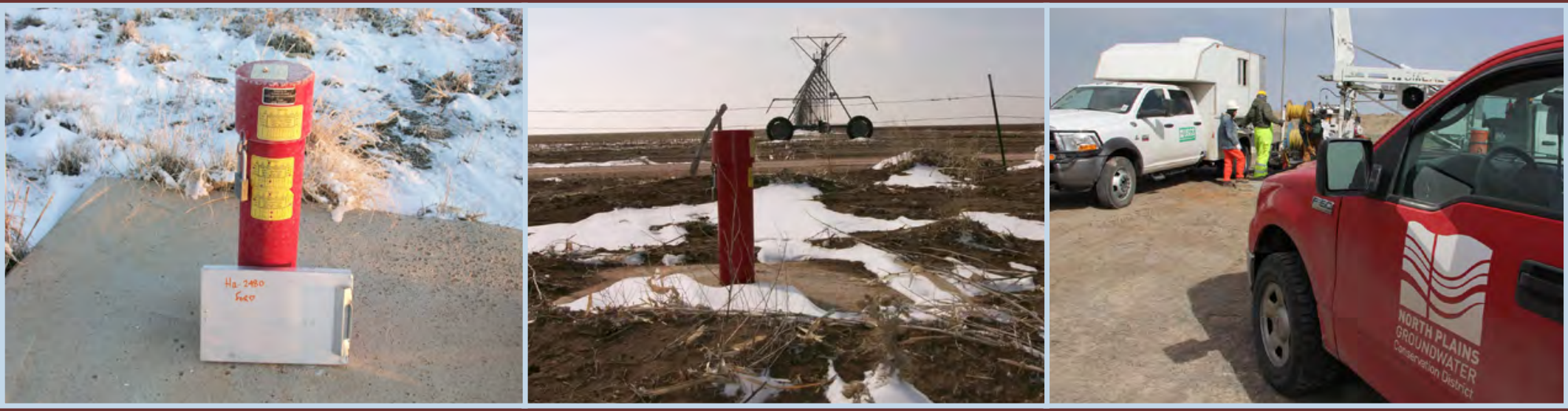

Scientific Investigations Report 2014-5188 


\section{Cover.}

Left, Sampling well Ha-2480 in Hartley County, Texas; photograph taken January 7, 2012, by Michael B. Nyman, U.S. Geological Survey, during reconnaissance survey.

Center, Sampling well Sh-2369 in Sherman County, Texas; photograph taken February 8, 2012, by Michael B. Nyman, U.S. Geological Survey, during reconnaissance survey.

Right, Sampling well Hn-3686 in Hansford County, Texas, with (left to right) Monti M. Haynie, Michael L. Willis, and Michael B. Nyman, U.S. Geological Survey, preparing to collect a sample; photograph taken March 8, 2012, by Michael S. Pitts, North Plains Groundwater Conservation District (used with permission). 


\section{Water Quality of the Ogallala Formation, Central High Plains Aquifer Within the North Plains Groundwater Conservation District, Texas Panhandle, 2012-13}

By Stanley Baldys III, Monti M. Haynie, and Amy M. Beussink

Prepared in cooperation with the North Plains Groundwater Conservation District

Scientific Investigations Report 2014-5188 


\title{
U.S. Department of the Interior SALLY JEWELL, Secretary
}

\section{U.S. Geological Survey Suzette M. Kimball, Acting Director}

\author{
U.S. Geological Survey, Reston, Virginia: 2014
}

For more information on the USGS — the Federal source for science about the Earth, its natural and living resources, natural hazards, and the environment, visit http://www.usgs.gov or call 1-888-ASK-USGS.

For an overview of USGS information products, including maps, imagery, and publications, visit http://www.usgs.gov/pubprod

To order this and other USGS information products, visit http://store.usgs.gov

Any use of trade, firm, or product names is for descriptive purposes only and does not imply endorsement by the U.S. Government.

Although this information product, for the most part, is in the public domain, it also may contain copyrighted materials as noted in the text. Permission to reproduce copyrighted items must be secured from the copyright owner.

Suggested citation:

Baldys, Stanley III, Haynie, M.M., and Beussink, A.M., 2014, Water quality of the Ogallala Formation, central High Plains aquifer within the North Plains Groundwater Conservation District, Texas Panhandle, 2012-13: U.S. Geological Survey Scientific Investigations Report 2014-5188, 64 p., http://dx.doi.org/10.3133/sir20145188.

ISSN 2328-0328 (online) 


\section{Contents}

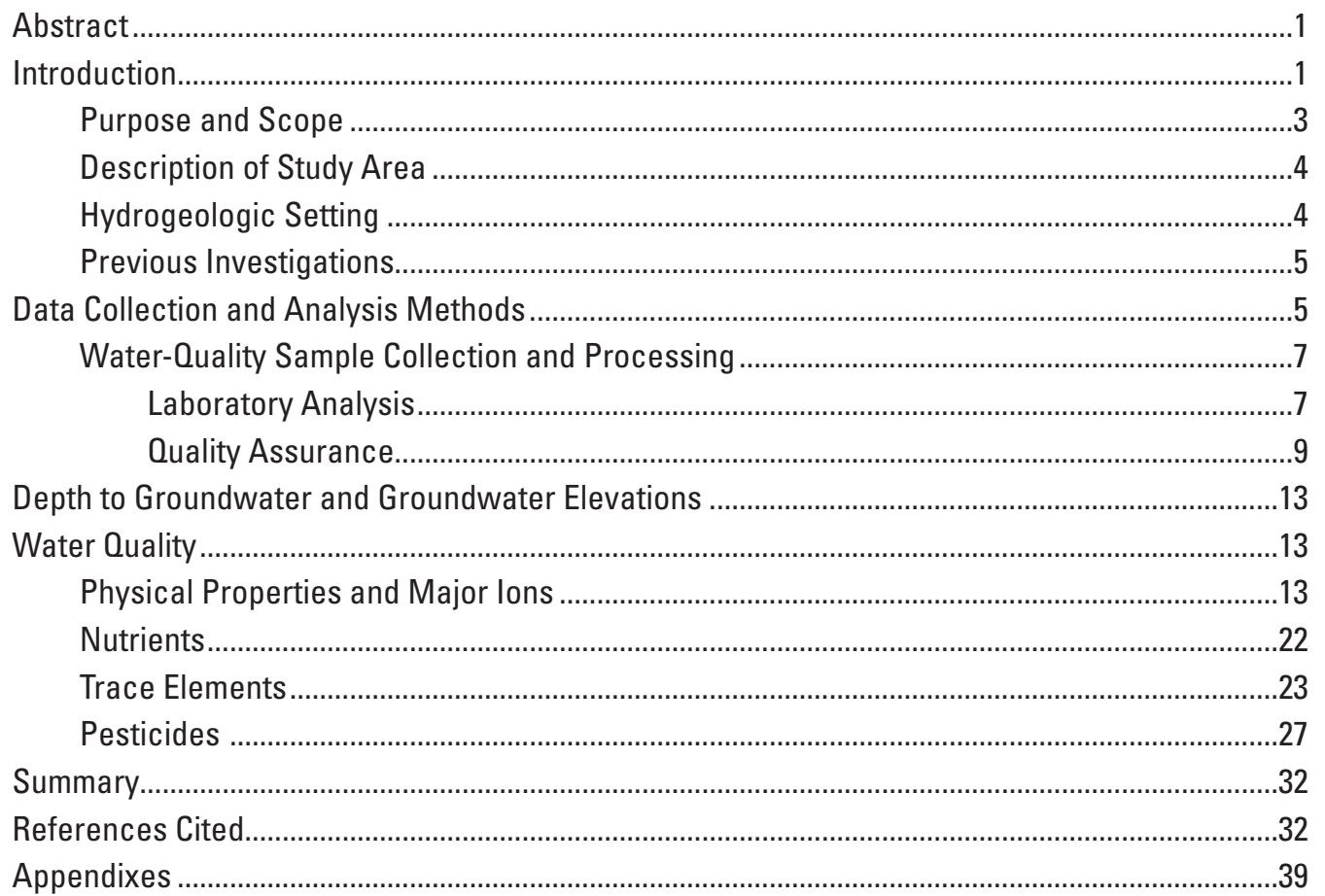

\section{Figures}

1. Map showing study area, the North Plains Groundwater Conservation District management area, and locations of 30 monitor wells completed in the Ogallala Formation of the central High Plains aquifer, Texas Panhandle, 2012-13.

2. Graph showing relation between dissolved-solids concentration and specific conductance measured in filtered and unfiltered samples, respectively, collected from 30 monitor wells in the North Plains Groundwater Conservation District management area in the Texas Panhandle, 2012-13.

3. Map showing dissolved-solids concentrations measured in filtered samples collected from 30 monitor wells in the North Plains Groundwater Conservation District management area, Texas Panhandle, 2012-13.

4. Boxplots showing the distribution of alkalinity and major-ion concentrations measured in filtered samples collected from 30 monitor wells in the North Plains Groundwater Conservation District management area in the Texas Panhandle, 2012-13

5. Piper (trilinear) diagram showing chemical composition of constituents measured in filtered samples collected from 30 monitor wells in the North Plains Groundwater Conservation District, Texas Panhandle, 2012-13. 
6. Map showing nitrate concentrations (nitrite plus nitrate) measured in filtered samples collected from 30 monitor wells and locations of selected wells where samples were collected for pesticide analyses, North

Plains Groundwater Conservation District, Texas Panhandle, 2012-13.

7. Boxplots showing trace-element concentrations measured in filtered samples collected from 30 monitor wells in the North Plains

Groundwater Conservation District, Texas Panhandle, 2012-13 25

8. Map showing arsenic concentrations measured in filtered samples collected from 30 monitor wells in the North Plains Groundwater Conservation District, Texas Panhandle, 2012-13.

\section{Tables}

1. Monitor wells completed in the Ogallala Formation of the central High Plains aquifer that were sampled during 2012-13, North Plains Groundwater Conservation District, Texas Panhandle

2. Laboratory analysis and field preservation methods for physical properties and water-quality constituents measured in groundwater samples collected from monitor wells in the North Plains Groundwater Conservation District, Texas Panhandle, 2012-13.

3. Water-quality constituents detected in quality-assurance samples collected from monitor wells in the North Plains Groundwater Conservation District, Texas Panhandle, 2012-13

4. Summary of blank-water sample results associated with samples collected from monitor wells in the North Plains Groundwater Conservation District, Texas Panhandle, 2012-13

5. Measured concentrations and 95-percent confidence intervals for the recovery of pesticides determined by using spiked and unspiked environmental samples collected from monitor wells in the North Plains Groundwater Conservation District, Texas Panhandle, 2012.

6. Summary statistics for physical properties, dissolved solids, major ions, nutrients, and trace elements measured in samples collected from 30 monitor wells in the North Plains Groundwater Conservation District, Texas Panhandle, 2012-13.

7. Pesticides and associated degradate compounds analyzed in water-quality samples collected from six monitor wells in the North Plains Groundwater Conservation District, Texas Panhandle, 2012

8. Concentrations of detected pesticides and 95-percent confidence intervals for the recovery of these detected pesticides measured in water-quality samples collected from six monitor wells in the North Plains Groundwater Conservation District Texas Panhandle, 2012 


\section{Conversion Factors}

Inch/Pound to SI

\begin{tabular}{lcl}
\hline & Multiply & To obtain \\
\hline inch (in.) & Length & \\
inch (in.) & 2.54 & centimeter $(\mathrm{cm})$ \\
foot (ft) & 25.4 & millimeter $(\mathrm{mm})$ \\
\hline & 0.3048 & meter $(\mathrm{m})$ \\
\hline acre & Area & square meter $\left(\mathrm{m}^{2}\right)$ \\
acre & 4,047 & hectare (ha) \\
acre & 0.4047 & square hectometer $\left(\mathrm{hm}^{2}\right)$ \\
acre & 0.4047 & square kilometer $\left(\mathrm{km}^{2}\right)$ \\
square mile $\left(\mathrm{mi}^{2}\right)$ & 0.004047 & hectare (ha) \\
square mile $\left(\mathrm{mi}^{2}\right)$ & 259.0 & square kilometer $\left(\mathrm{km}^{2}\right)$ \\
\hline & 2.590 & \\
\hline gallon (gal) & Volume & liter (L) \\
acre-foot (acre-ft) & 3.785 & cubic meter $\left(\mathrm{m}^{3}\right)$ \\
acre-foot (acre-ft) & 1,233 & cubic hectometer $\left(\mathrm{hm}^{3}\right)$ \\
\hline
\end{tabular}

Temperature in degrees Celsius $\left({ }^{\circ} \mathrm{C}\right)$ may be converted to degrees Fahrenheit $\left({ }^{\circ} \mathrm{F}\right)$ as follows:

${ }^{\circ} \mathrm{F}=\left(1.8 x^{\circ} \mathrm{C}\right)+32$

Temperature in degrees Fahrenheit $\left({ }^{\circ} \mathrm{F}\right)$ may be converted to degrees Celsius $\left({ }^{\circ} \mathrm{C}\right)$ as follows: ${ }^{\circ} \mathrm{C}=\left({ }^{\circ} \mathrm{F}-32\right) / 1.8$

Vertical coordinate information is referenced to the World Geodetic System of 1984 (WGS 84).

Horizontal coordinate information is referenced to the North American Datum of 1983 (NAD 83).

Elevation, as used in this report, refers to distance above the vertical datum.

Specific conductance is given in microsiemens per centimeter at 25 degrees Celsius $(\mu \mathrm{S} / \mathrm{cm}$ at $\left.25^{\circ} \mathrm{C}\right)$.

Concentrations of chemical constituents in water are given in either milligrams per liter (mg/L) or micrograms per liter $(\mu \mathrm{g} / \mathrm{L})$. 


\section{Abbreviations}

$\begin{array}{ll}\text { AMPA } & \text { aminomethylphosphonic acid } \\ \text { CaCO }_{3} & \text { calcium carbonate } \\ \text { CIAT } & \text { 2-Chloro-4-isopropylamino-6-amino-s-triazine } \\ \text { CICP-MS } & \text { collision/reaction cell inductively coupled plasma-mass spectrometry } \\ \text { DCPA } & \text { Dacthal } \\ \text { DO } & \text { dissolved oxygen } \\ \text { DS } & \text { dissolved solids } \\ \text { EPTC } & \text { S-Ethyl dipropylthiocarbamate } \\ \text { Esri } & \text { Environmental Systems Research Institute } \\ \text { GC/MS } & \text { gas chromatography/mass spectrometry } \\ \text { HBSL } & \text { health-based screening level } \\ \text { HCO } & \text { bicarbonate } \\ \text { HNO } & \text { nitric acid } \\ \text { HPLC/MS } & \text { inductively coupled plasma-mass spectrometry } \\ \text { HT } & \text { herbicide tolerant } \\ \text { ICP-AES } & \text { inductively coupled plasma-atomic emission mass spectrometry } \\ \text { ICP-MS } & \text { inductively coupled plasma-mass spectrometry } \\ \text { LC/MS/MS } & \text { liquid chromatography/tandem mass spectrometry } \\ \text { LRL } & \text { laboratory reporting level } \\ \text { LT-MDL } & \text { long-term method detection level } \\ \text { MCL } & \text { maximum contaminant level } \\ \text { N } & \text { nitrogen } \\ \text { NAWOA } & \text { National Water-Quality Assessment } \\ \text { NPGCD } & \text { North Plains Groundwater Conservation District } \\ \text { NTRU } & \text { nephelometric turbidity ratio units } \\ \text { NWIS } & \text { National Water Information System } \\ \text { NWOL } & \text { National Water Quality Laboratory } \\ \text { OGRL } & \text { Organic Geochemistry Research Laboratory } \\ \text { P } & \text { phosphorus } \\ \mathrm{R}^{2} & \text { coefficient of determination } \\ \text { redox } & \text { oxidation and reduction } \\ \text { RPD } & \text { relative percent difference } \\ \text { SAR } & \text { sodium-adsorption ratio } \\ \text { SiO } & \text { silicon dioxide } \\ \text { SPE } & \text { solid-phase extraction } \\ \text { TCEO } & \text { Texas Commission on Environmental Quality } \\ \text { TRRP } & \text { Texas Risk Reduction Program } \\ \text { EPA } & \text { U.S. Environmental Protection Agency } \\ \text { USGS } & \text { U.S. Geological Survey } \\ \text { WGS } 84 & \text { World Geodetic System of 1984 } \\ & \end{array}$




\title{
Water Quality of the Ogallala Formation, Central High Plains Aquifer Within the North Plains Groundwater Conservation District, Texas Panhandle, 2012-13
}

\author{
By Stanley Baldys III, Monti M. Haynie, and Amy M. Beussink
}

\begin{abstract}
In cooperation with the North Plains Groundwater Conservation District (NPGCD), the U.S. Geological Survey collected and analyzed water-quality samples at 30 groundwater monitor wells in the NPGCD in the Texas Panhandle. All of the wells were completed in the Ogallala Formation of the central High Plains aquifer. Samples from each well were collected during February-March 2012 and in March 2013. Depth to groundwater in feet below land surface was measured at each well before sampling to determine the water-quality sampling depths. Water-quality samples were analyzed for physical properties, major ions, nutrients, and trace metals, and 6 of the 30 samples were analyzed for pesticides. There was a strong relation between specific conductance and dissolved solids as evidenced by a coefficient of determination $\left(R^{2}\right)$ value of 0.98 . The dissolved-solids concentration in water from five wells exceeded the secondary drinking-water standard of 500 milligrams per liter set by the U.S. Environmental Protection Agency. Water from 3 of these 5 wells was near the north central part of the NPGCD. Nitrate values exceeded the U.S. Environmental Protection Agency maximum contaminant level of 10 milligrams per liter in 2 of the 30 wells. A sodium-adsorption ratio of 23.4 was measured in the sample collected from well Da-3589 in Dallam County, with the next largest sodium-adsorption ratio measured in the sample collected from well Da-3588 (12.5), also in Dallum County. The sodium-adsorption ratios measured in all other samples were less than 10 . The groundwater was generally a mixed cation-bicarbonate plus carbonate type. Twentythree trace elements were analyzed, and no concentrations exceeded the secondary drinking-water standard or maximum contaminant level set by the U.S. Environmental Protection Agency for water supplies. In 2012, 6 of the 30 wells were sampled for commonly used pesticides. Atrazine and its degradate 2-Chloro-4-isopropylamino-6-amino-s-triazine were detected in two samples. Tebuthiuron was detected in one sample at a detection level below the reporting level but above the long-term method detection level. There were no detections of the glyphosate, aminomethylphosphonic acid (AMPA), or glufosinate.
\end{abstract}

\section{Introduction}

The High Plains aquifer is a vast, extensively used groundwater system underlying 111.8 million acres in parts of Colorado, Kansas, Nebraska, New Mexico, Oklahoma, South Dakota, Wyoming, and Texas (McGuire, 2012). The High Plains aquifer system consists of (1) the northern High Plains aquifer in Wyoming, South Dakota, Nebraska, and parts of Colorado and Kansas; (2) the central High Plains aquifer in Kansas and parts of Colorado, New Mexico, Oklahoma, and the Texas Panhandle; and (3) the southern High Plains aquifer south of Amarillo, Tex., extending into eastern New Mexico (Becker and others, 2002). The High Plains aquifer system supplies 30 percent of the irrigated groundwater used in the United States and serves as the most important agricultural and, in some cases, public-water supply resource in many areas of the eight States it underlies (Becker and others, 2002). The amount of groundwater in the High Plains aquifer system is rapidly being depleted. Between 2000 and 2010, the amount of groundwater in storage in the North Plains Groundwater Conservation District (NPGCD) decreased from 124,439,507 acre feet (acre-ft) to 113,331,185 acre-ft (North Plains Groundwater Conservation District, 2013). A recent study funded by the National Science Foundation by researchers from Kansas State University indicates that if current (2014) irrigation trends continue, 69 percent of the groundwater stored in the High Plains aquifer of Kansas will be depleted in 50 years (Steward and others, 2013). Describing the deterioration of water quality associated with groundwater depletions, Bartolino and Cunningham (2003, p. 3) note "withdrawal of good-quality water from the upper parts of inland aquifers can allow underlying saline water to move upward and degrade water quality. Additionally, where groundwater is pumped from an aquifer, surface water of poor or differing quality may be drawn into the aquifer. This can degrade the water quality of the aquifer directly or mobilize naturally occurring contaminants in the aquifer."

Counties in the Texas Panhandle (including Dallam, Sherman, Hansford, Ochiltree, Lipscomb, Hartley, Moore, and Hutchinson in the study area) (fig. 1) use the central High Plains aquifer as their primary source of water for agricultural 


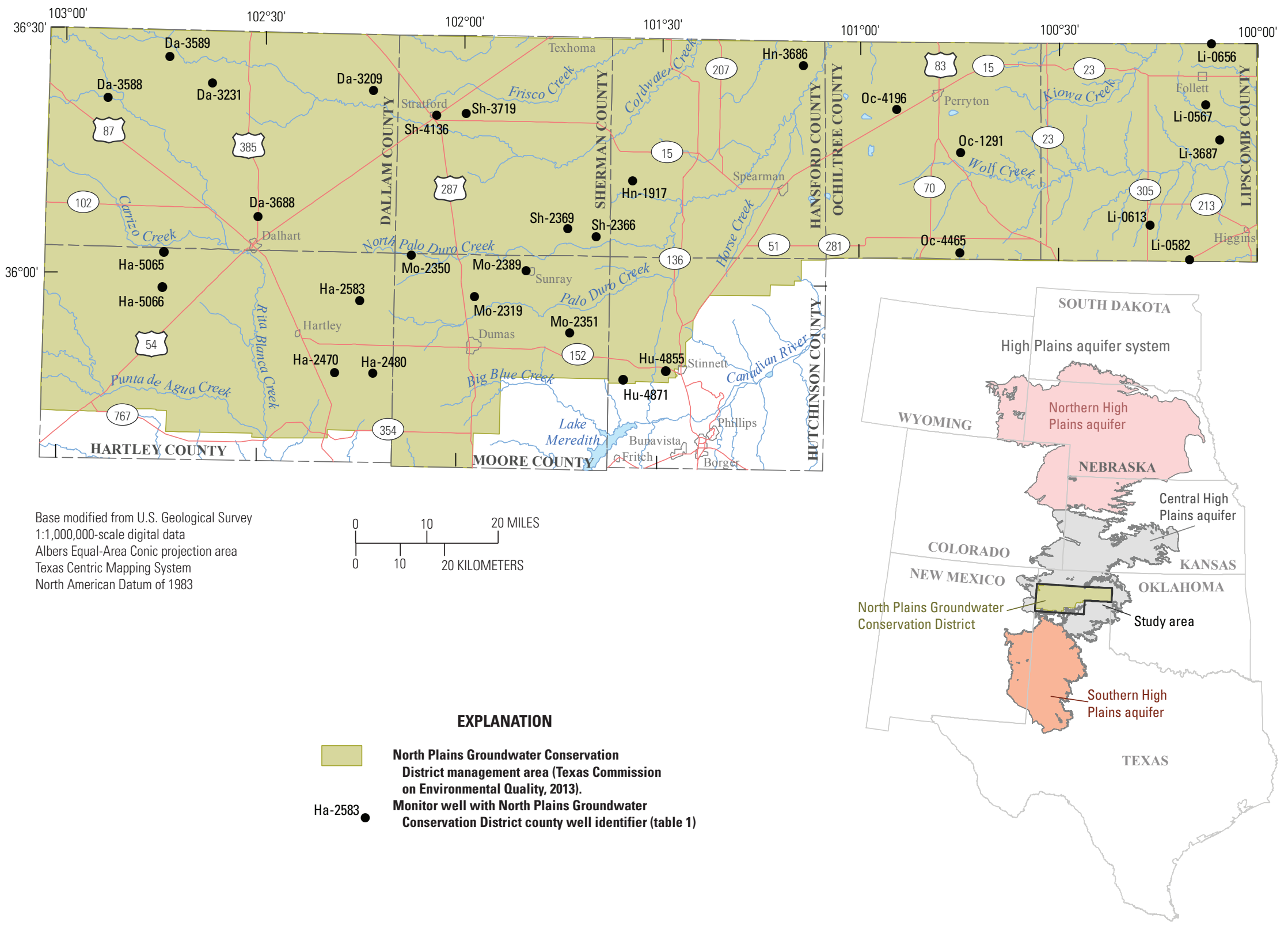

Figure 1. Study area, the North Plains Groundwater Conservation District management area, and locations of 30 monitor wells completed in the 0gallala Formation of the central High Plains aquifer, Texas Panhandle, 2012-13. 
and municipal purposes. Most of the water withdrawn in Texas from the central High Plains aquifer is extracted from the Ogallala Formation primarily of late Tertiary age, with locally unconsolidated deposits of Quaternary age (Gutentag and others, 1984; Ryder, 1996). Because most of the water withdrawn from the central High Plains aquifer in Texas is extracted from the Ogallala Formation, information on the quality of water in the Ogallala Formation is useful for resource characterization. General water-quality characteristics such as dissolved-solids, nutrient, and trace element concentrations help in the understanding of how water in the central High Plains aquifer varies spatially and temporally; this type of information can be used to help make better informed water-management decisions. Knowledge of the concentrations of pesticides and herbicides and their degradates (organic compounds collectively referred to as "pesticides") in the Ogallala Formation of the central High Plains aquifer also is important for groundwater characterization and management purposes. Historically, few pesticide data have been available for groundwater in the Ogallala Formation because analytical methods were not available to determine pesticides at low concentrations at which they might be present.

The use of some pesticides, such as the herbicide glyphosate, has changed with the development of herbicide tolerant crops. The U.S. Department of Agriculture Economic Research Service (2014) documents the widespread planting of herbicide tolerant (HT) soybeans, cotton, and corn and notes "HT soybeans went from 17 percent of U.S. soybean acreage in 1997 to 68 percent in 2001 and 94 percent in 2014. Plantings of HT cotton expanded from about 10 percent of U.S. acreage in 1997 to 56 percent in 2001 and 91 percent in 2014. The adoption of HT corn, which had been slower in previous years, has accelerated, reaching 89 percent of U.S. corn acreage in 2014." Coinciding with the rapid increase in HT crop production in the United States, glyphosate usage increased markedly such that this herbicide has become the most used conventional pesticide in the United States agricultural market sector (U.S. Environmental Protection Agency, 2014). Battaglin and others (2014) report that between 1987 and 2007, nationwide glyphosate use increased about sixteenfold, from less than 5,000 metric tons per year to more than 80,000 metric tons per year. In 2007, an analytical method was developed by the U.S. Geological Survey (USGS) Organic Geochemistry Research Laboratory (OGRL) in Lawrence, Kans., that uses solid-phase extraction (SPE), gas chromatography/mass spectrometry (GC/MS), and liquid chromatography/tandem mass spectrometry (LC/MS/ MS) to detect and measure pesticides, such as the herbicide glyphosate, its degradation product aminomethylphosphonic acid (AMPA), and the herbicide glufosinate at very low concentrations in groundwater throughout the United States (Scribner and others, 2007). The herbicide atrazine is the second most commonly used conventional pesticide in the United States after glyphosate (U.S. Environmental Protection Agency, 2014). Atrazine use from 2001 to 2007 principally remained unchanged at about 33,000 metric tons of the active ingredient 2-Chloro-4-isopropylamino-6-amino-s-triazine (CIAT) (U.S. Environmental Protection Agency, 2011).

The NPGCD has regulatory authority for the central High Plains aquifer in the Texas Panhandle. Groundwater resources north of the Canadian River (fig. 1) are managed by the NPGCD, which was created by Petition to the State Board of Water Engineers in 1954 (North Plains Groundwater Conservation District, 2013). The NPGCD covers 7,324 square miles and is charged by the Texas Water Development Board with managing groundwater in the Ogallala Formation for the conservation, protection, and preservation of this valuable resource that also is restated in the mission statement of the NPGCD, "maintaining our way of life through conservation, protection, and preservation of our groundwater resources" (North Plains Groundwater Conservation District, 2013).

Available information on the water quality in the Ogallala Formation of the central High Plains aquifer in the Texas Panhandle is sparse. The NPGCD collects waterquality samples for selected physical properties, major ions, nutrients, and bacteria at several monitoring wells on a 5-year revolving cycle (North Plains Groundwater Conservation District, 2013). The constituents analyzed include $\mathrm{pH}$, specific conductance, dissolved solids, calcium, magnesium, sodium, chloride, fluoride, sulfate, nitrate, iron, and total hardness. Within the NPGCD, the saturated thickness of some areas of the High Plains aquifer have declined by more than 50 percent from 1950 (before substantial groundwater irrigation development began) to 2011 (McGuire, 2012); these declines might be affecting water quality within the aquifer. Recent recharge to the aquifer from precipitation and surface water is minimal (North Plains Groundwater Conservation District, 2013). Monitoring the quality of water in the Ogallala Formation of the central High Plains aquifer is an important aspect of groundwater management in the Texas Panhandle. Evaluating water-quality characteristics is vital for determining the suitability and availability of this water for various uses and for determining if the quality is changing with time (North Plains Groundwater Conservation District, 2013). Accordingly, the USGS, in cooperation with the NPGCD, completed a reconnaissance-level survey of the water quality in the Ogallala Formation of the High Plains aquifer in the Texas Panhandle. All of the wells used in the study were designated monitor wells (wells used exclusively for monitoring groundwater levels and collecting waterquality samples to characterize groundwater resources) within the NPGCD management area and part of a groundwater monitoring network maintained by NPGCD.

\section{Purpose and Scope}

The purpose of this report is to document the results of a reconnaissance-level survey in cooperation with the NPGCD of the water quality in the Ogallala Formation within the 
NPGCD management area of the central High Plains aquifer in the Texas Panhandle. Depth to groundwater measurements and water-quality samples were collected from 30 monitor wells in the NPGCD management area as part of a synoptic sampling effort during February-March 2012 and in March 2013 (fig.

1). Water-quality samples were collected for analysis of dissolved solids and major ions, nutrients, and trace elements; selected pesticides also were analyzed in a subset of samples collected during 2012. Sample results for selected constituents are compared to drinking-water standards and results from other studies of the High Plains aquifer and (or) nationwide studies. The water-quality data that were collected are assessed in the context of results obtained from quality-control samples collected in conjunction with the environmental samples.

\section{Description of Study Area}

The study area for this report coincides with the area managed by the NPGCD, which consists of the five northernmost counties that form the border between Texas and Oklahoma (Dallam, Sherman, Hansford, Ochiltree, and Lipscomb Counties) and parts of Hartley, Moore, and Hutchinson Counties north of the Canadian River where the Ogallala Formation of the High Plains aquifer is present in the subsurface (fig. 1). The Canadian River separates the central High Plains aquifer from the southern High Plains aquifer in the study area (Trimble, 1980). The study area covers 7,324 square miles of which 25 percent was in agricultural production during 2012 (North Plains Groundwater District, 2013). The study area is in one of the primary agricultural regions in the Nation. Rainfall is sparse, and in parts of the area, farmers and ranchers began extensive use of groundwater for irrigation in the 1930s and 1940s (Beaumont, 1985). Average annual rainfall for the study area ranges from 17.6 inches (in.) at Dalhart, Tex. (Dallam County), in the west to 23.4 in. in Follett, Tex. (Lipscomb County), in the east (U.S. Department of Commerce, National Climatic Data Center, 2014). As of 2010, there also were 81,854 residents in the study area, and most depended on groundwater for their municipal needs (Texas Water Development Board, 2013). The study area is a broad plateau, and despite land-surface elevations decreasing appreciably west to east from 4,750 to 2,900 feet (ft), the study area seems almost flat (Wermund, 1996). Compared to long-term averages, rainfall for the study area was much less during 2012-13. For example, an average of only $6.33 \mathrm{in}$. of rainfall was reported at the Dalhart Municipal Airport (U.S. Department of Commerce, National Climatic Data Center, 2014) during 2012-13. The severe drought in 2012-13 increased demands on groundwater resources.

With rainfall sparse, recharge to the aquifer in the study area is minimal. For the entire High Plains aquifer, Gutentag and others (1984) estimated that mean annual potential groundwater recharge rates ranged from 0.05 to $1.85 \mathrm{in.}$ per year. In the study area, NPGCD estimates that average annual recharge rates are less than one-third of an inch per year (North Plains Groundwater Conservation District, 2013). Most recharge is from precipitation infiltrating the ground surface and reaching the water table (McGuire, 2012). Given the severe drought conditions during 2012-13, it is likely that there was mostly no recharge when sampling was completed for this study.

\section{Hydrogeologic Setting}

The Ogallala Formation is the principal geologic unit of the central High Plains aquifer in Texas and most important water-bearing formation in the study area (Gutentag and others, 1984; Ryder, 1996). Authorities from the NPGCD report that the average thickness of the Ogallala Formation in the study area ranges from $129 \mathrm{ft}$ in Dallam County to $233 \mathrm{ft}$ in Lipscomb County with an estimated study-area-wide average aquifer thickness of $173 \mathrm{ft}$ (North Plains Groundwater Conservation District, 2013). The depth from land surface to the base of the Ogallala Formation of the central High Plains aquifer ranges from 0 (at land surface) to 1,000 ft below land surface; static water levels range from land surface to $500 \mathrm{ft}$ below land surface, reference datum is World Geodetic System of 1984 (WGS 84) (North Plains Groundwater Conservation District, 2013). Annual groundwater withdrawals reported by the NPGCD were 2,048,411 acre-ft in 2011 and 1,869,169 acre-ft in 2012. By comparison, in 2007, the first year that the NPGCD reported annual withdrawal amounts, groundwater withdrawals were considerably less, totaling 1,178,033 acre-ft (North Plains Groundwater Conservation District, 2013).

Ryder (1996, p. E12) provides the following description of the hydrogeologic setting of the High Plains aquifer - a description relevant to the central High Plains aquifer in Texas:

The High Plains aquifer consists predominantly of the Ogallala Formation of late Tertiary age; locally, unconsolidated deposits of Quaternary age are included in the aquifer. In places, the High Plains aquifer is in hydraulic connection with permeable parts of the underlying bedrock, which ranges in age from Permian to Cretaceous. The High Plains aquifer $* * *$ has been called the Ogallala aquifer in many published reports. The age of the Ogallala Formation is considered to be Miocene***. At the close of deposition of the Ogallala Formation several million years ago, the Great Plains was a vast, gently sloping plain***. Regional uplift and erosion stripped away the plain in many places, but a large central area was little affected by eroding streams and is preserved. This preserved remnant of the uplifted Ogallala Formation is known as the High Plains. Although the land surface of the High Plains has been modified little by streams, it has been pitted by carbonate dissolution and deflation, thus forming many playas, or shallow depressions, that collect and store water during periods of precipitation and runoff. The 
Canadian River has cut through much of the Ogallala Formation in the Texas Panhandle. The High Plains south of the Canadian River is referred to locally and regionally as the Southern High Plains.

The Ogallala Formation consists primarily of heterogeneous sequences of coarse-grained sand and gravel. The sediments originate from alluvial fan deposits and fluvial, lacustrine, and eolian deposits (North Plains Groundwater Conservation District, 2013; Ryder, 1996).

\section{Previous Investigations}

In response to concerns about water-level declines, Title III of the Water Resources Research Act of 1984 (U.S. Public Law 98-242, 99-662) directs the USGS to monitor water levels in the High Plains aquifer in cooperation with States where the aquifer system exists and report the findings annually to Congress (Dugan and others, 1990). An example of a recent report published by the USGS under this directive was completed by McGuire (2012). In addition to ongoing studies led by the USGS, the NPGCD annually measures groundwater levels at 430 monitor wells between January and the first part of March each year throughout the area of its jurisdiction and publishes water-level maps depicting groundwater-elevation contours (North Plains Groundwater Conservation District, 2013).

Augmenting the available groundwater-level data for the study area, some previous groundwater-quality data relevant to the central High Plains aquifer in Texas were collected by the NPGCD or by the USGS as part of the National WaterQuality Assessment (NAWQA) program. The NPGCD monitors groundwater quality by analyzing samples collected from selected monitor wells for physical properties, major ions, nutrients, and bacteria. The NPGCD samples monitor wells each year, and a subset of the same 430 monitor wells are sampled every 5 years. These data are compiled and presented in NPGCD's annual reports (North Plains Groundwater Conservation District, 2013). Becker and others (2002) sampled 74 domestic water-supply wells in the central High Plains aquifer for physical properties, major ions, nutrients, organic carbon, trace elements, radon, pesticides, and volatile organic compounds. Of the wells sampled by Becker and others (2002), 17 were within the NPGCD management area. McMahon (2000) presents the results from a reconnaissance-level study describing wells completed in the Ogallala Formation that might have received recent recharge (water recharged during the 50 years prior to when they collected their samples). Results of this study indicated that recent recharge was present in the Ogallala Formation in 4 of 5 sampled wells (McMahon, 2000); the implications of these findings likely only apply to those wells and parts of the Ogallala Formation near these wells. None of the wells sampled during the McMahon (2000) study were within the NPGCD management area. Bruce and others (2003) investigated groundwater quality beneath irrigated land in 30 groundwater wells spread across the area denoted as the central
High Plains aquifer; most of the wells they sampled were in Kansas, and no wells were within the area managed by the NPGCD. Water samples from 70 percent of the wells (21 of 30 sites) sampled by Bruce and others (2003) contained nitrate concentrations larger than expected background concentrations (about 3 milligrams per liter $[\mathrm{mg} / \mathrm{L}]$ as nitrogen) and contained detectable pesticides. As part of the NAWQA High Plains aquifer study, McMahon and others (2006) reported on storage and transit time of chemicals in unsaturated zones, McMahon and Böhlke (2006) described regional patterns in the isotopic composition of nitrate in groundwater, and McMahon and others (2007) reported on water-quality characteristics of the aquifer. Barbash and Resek (1996) and Kolpin and others (1998) provide a nationwide perspective on application rates and types of pesticides applied and their occurrence in groundwater in various parts of the Nation, including the High Plains aquifer. Scribner and others (2007) investigated glyphosate, AMPA, and glufosinate concentrations in a nationwide study of groundwater, surface water, rainfall, and soil samples with one of the areas studied being in the northern High Plains aquifer, even though none of the samples collected as part of this study were from the central High Plains aquifer region administered by the NPGCD. Ayotte and others (2011) summarized trace metal data from samples collected nationally between 1992 and 2003, which included data for selected trace metals from wells within the study area.

\section{Data Collection and Analysis Methods}

The depth to groundwater was measured and groundwater elevation was calculated by USGS personnel for each of the 30 monitor wells (hereinafter referred to as "wells") from which water-quality samples were collected during the study (fig. 1, table 1) The depth to groundwater was measured to ensure that when water-quality sampling began, the sampling hose intake was at a proper depth to provide a representative sample from the well. The depth to groundwater was measured by using a calibrated electric tape in accordance with methods described in Cunningham and Schalk (2011). The electric tape is calibrated before use with a steel reference tape. A reference tape is one that is maintained in the office only to calibrate other tapes. An electric tape commonly is accurate to plus or minus $0.01 \mathrm{ft}$ and is most accurate for water levels less than $200 \mathrm{ft}$ below land surface (Cunningham and Schalk, 2011). The groundwater elevation was computed by subtracting the depth to groundwater from the land surface elevation (WGS 84). The depth to groundwater-level data were entered and archived in the USGS National Water Information System (NWIS) (U.S. Geological Survey, 2014a).

NPGCD county well identifiers assigned to each well are used to identify the wells in this report. The NPGCD county well identifier consists of the first two letters of the county name followed by a sequence of four numbers (Dale Hallmark, NPGCD, written commun., 2014). The county 
Table 1. Monitor wells completed in the Ogallala Formation of the central High Plains aquifer that were sampled during 2012-13, North Plains Groundwater Conservation District, Texas Panhandle.

[USGS, U.S. Geological Survey; NPGCD, North Plains Groundwater Conservation District; ft, feet; \#, number; (S), south; (E), east; (W), west]

\begin{tabular}{|c|c|c|c|c|c|c|c|c|c|c|c|}
\hline $\begin{array}{l}\text { USGS station } \\
\text { number }\end{array}$ & $\begin{array}{l}\text { State well } \\
\text { number }\end{array}$ & County & $\begin{array}{c}\text { NPGCD } \\
\text { county } \\
\text { well } \\
\text { identifier } \\
\text { (figs. 1, 3, } \\
5,6 \text {, and 8) }\end{array}$ & $\begin{array}{l}\text { NPGCD } \\
\text { site name }\end{array}$ & $\begin{array}{c}\text { Land } \\
\text { surface } \\
\text { elevation } \\
\text { (ft) }\end{array}$ & $\begin{array}{c}\text { Total } \\
\text { well } \\
\text { depth } \\
\text { (ft below } \\
\text { land } \\
\text { surface) }\end{array}$ & $\begin{array}{l}\text { Depth to } \\
\text { groundwater } \\
\text { (ft below land } \\
\text { surface) }\end{array}$ & $\begin{array}{c}\text { Sampling } \\
\text { depth } \\
\text { (ft below } \\
\text { land } \\
\text { surface) }\end{array}$ & $\begin{array}{l}\text { Sampling } \\
\text { date }\end{array}$ & $\begin{array}{l}\text { Sampling } \\
\text { time }\end{array}$ & $\begin{array}{c}\text { Groundwater } \\
\text { elevation } \\
\text { (ft) }\end{array}$ \\
\hline 362308102132801 & HP-02-39-703 & Dallam & Da-3209 & Grassland \#11 & 3,827 & 540 & 307.3 & 320 & $3 / 26 / 2013$ & 1740 & 3,520 \\
\hline 362341102375101 & HP-02-35-901 & Dallam & Da-3231 & Grassland \#8 & 4,217 & 600 & 168.1 & 220 & $3 / 4 / 2012$ & 1000 & 4,049 \\
\hline 362648102442201 & HP-02-35-404 & Dallam & Da-3589 & Grassland \#4 & 4,310 & 600 & 177.6 & 260 & $3 / 3 / 2012$ & 1700 & 4,132 \\
\hline 362137102533001 & HP-02-41-305 & Dallam & Da-3588 & Grassland \#2 & 4,418 & 600 & 257.5 & 300 & $3 / 3 / 2012$ & 1230 & 4,160 \\
\hline 360727102303101 & HР-02-60-303 & Dallam & Da-3688 & Warfield Brothers & 4,006 & 560 & 391.1 & 420 & $3 / 22 / 2013$ & 1200 & 3,615 \\
\hline 360546101393301 & XD-03-59-301 & Sherman & Sh-2366 & Cartrite \#1 & 3,383 & 450 & 290.5 & 320 & $3 / 1 / 2012$ & 1500 & 3,092 \\
\hline 360640101434901 & XD-03-59-105 & Sherman & Sh-2369 & Cartrite \#2 & 3,434 & 475 & 308.2 & 340 & $3 / 1 / 2012$ & 1045 & 3,126 \\
\hline 362019102035301 & $\mathrm{XD}-02-48-2 \mathrm{xx}$ & Sherman & Sh-4136 & Spurlock & 3,689 & 465 & 315.3 & 320 & $3 / 26 / 2013$ & 1400 & 3,374 \\
\hline 362035101592801 & XD-03-41-1xx & Sherman & Sh-3719 & Donelson & 3,612 & 470 & 319.7 & 340 & $3 / 26 / 2013$ & 0940 & 3,292 \\
\hline 361242101341001 & LB-03-52-203 & Hansford & Hn-1917 & Jarvis & 3,322 & 510 & 201.7 & 220 & $3 / 2 / 2012$ & 1120 & 3,120 \\
\hline 362700101083801 & LB-03-39-603 & Hansford & Hn-3686 & Stavlo & 2,980 & 580 & 214.7 & 240 & $3 / 8 / 2012$ & 1230 & 2,765 \\
\hline 360416100445001 & UD-04-59-4xx & Ochiltree & Oc-4465 & Cook & 2,881 & 595 & 340.3 & 360 & $3 / 27 / 2013$ & 1620 & 2,541 \\
\hline 361631100444801 & UD-04-43-701 & Ochiltree & Oc-1291 & Pshigoda & 2,905 & 530 & 317.4 & 340 & $3 / 27 / 2013$ & 1125 & 2,588 \\
\hline 362146100542801 & UD-04-41-3xx & Ochiltree & Oc-4196 & Krienke & 2,973 & 515 & 286.6 & 320 & $3 / 8 / 2012$ & 1715 & 2,686 \\
\hline 360332100101401 & SH-04-63-502 & Lipscomb & Li-0582 & Rader \#1 & 2,703 & 590 & 217.6 & 240 & $3 / 5 / 2012$ & 1300 & 2,485 \\
\hline 360743100161001 & SH-04-54-902 & Lipscomb & Li-0613 & Rader \#2 & 2,610 & 530 & 76.60 & 120 & $3 / 6 / 2012$ & 1500 & 2,533 \\
\hline 361813100054301 & SH-04-48-401 & Lipscomb & Li-3687 & Weidner & 2,472 & 360 & 193.4 & 220 & $3 / 6 / 2012$ & 1000 & 2,279 \\
\hline 362234100075201 & SH-04-39-903 & Lipscomb & Li-0567 & Born \#1 & 2,473 & 460 & 114.0 & 140 & $3 / 7 / 2012$ & 1600 & 2,359 \\
\hline 362959100065801 & SH-04-40-103 & Lipscomb & Li-0656 & Born \#2 & 2,570 & 405 & 186.0 & 220 & $3 / 7 / 2012$ & 1100 & 2,384 \\
\hline 355827102443501 & LL-07-03-101 & Hartley & На-5066 & Baumann \#2 & 4,103 & 535 & 201.2 & 220 & $3 / 29 / 2013$ & 0945 & 3,902 \\
\hline 360241102443401 & LL-02-59-403 & Hartley & На-5065 & Baumann \#1 & 4,160 & 555 & 345.9 & 360 & $3 / 23 / 2013$ & 1200 & 3,814 \\
\hline 354832102124701 & LL-07-15-403 & Hartley & На-2480 & Ford & 3,840 & 655 & 451.8 & 480 & $3 / 4 / 2012$ & 1730 & 3,388 \\
\hline 354833102182901 & LL-07-14-502 & Hartley & На-2470 & Cover & 3,905 & 600 & 475.4 & 480 & $3 / 22 / 2013$ & 1745 & 3,430 \\
\hline 355725102145501 & LL-07-07-404 & Hartley & На- 2583 & Schniederjan \#1 (S) & 3,888 & 605 & 480.8 & 500 & $3 / 21 / 2013$ & 1800 & 3,407 \\
\hline 355357101431901 & TT-06-03-710 & Moore & Mo-2351 & Stringer \#1 (E) & 3,438 & 475 & 277.8 & 300 & $2 / 28 / 2012$ & 1300 & 3,160 \\
\hline 355810101574501 & TT-06-01-117 & Moore & Mo-2319 & Gillespie & 3,611 & 625 & 420.1 & 440 & $3 / 20 / 2013$ & 1630 & 3,191 \\
\hline 360128101500001 & TT-03-58-709 & Moore & Mo-2389 & City of Sunray & 3,508 & 515 & 335.0 & 360 & $2 / 29 / 2012$ & 1300 & 3,173 \\
\hline 360307102071801 & TT-02-64-407 & Moore & Mo- 2350 & Stringer \#2 (W) & 3,712 & 635 & 410.3 & 420 & $3 / 21 / 2013$ & 1230 & 3,302 \\
\hline 354810101351501 & PJ-04-12-4xx & Hutchinson & Hu-4871 & Borger L2 & 3,203 & 378 & 174.2 & 200 & $3 / 25 / 2013$ & 1535 & 3,029 \\
\hline 354919101285301 & PJ-06-13-4xx & Hutchinson & $\mathrm{Hu}-4855$ & Borger B2 & 3,200 & 360 & 247.6 & 260 & $3 / 25 / 2013$ & 1200 & 2,952 \\
\hline
\end{tabular}

${ }^{1}$ Land surface elevation is referenced to the World Geodetic System of 1984 (Dale Hallmark, NPGCD, written commun., 2014).

${ }^{2}$ Land surface elevation minus depth to groundwater at time sample was collected. 
well identifiers assigned by NPGCD supplement the 15-digit USGS site numbers used to identify each well in the NWIS database (U.S. Geological Survey, 2014a). The NWIS 15-digit site numbers consist of the latitude and longitude followed by a 2-digit sequence number. Each well also has a State well number (table 1).

Measuring-point elevations and land-surface elevations were determined for each well. Measuring-point elevation, the distance above the land-surface elevation at which the electric tape is read, was determined in the field and used to determine the depth to groundwater for each site. The land-surface elevation was determined by the NPGCD from a contour base map produced by the Environmental Systems Research Institute (Esri) by using World Geodetic System of 1984 (WGS 84) (Dale Hallmark, NPGCD, written commun., 2014).

The wells were developed by an independent contractor or by the NPGCD usually 2-7 days before the USGS sampling personnel arrived at the site. During well development, the well depth is determined and then the column of water is divided into 3 or 4 separate sections that are emptied by use of a small pump operated for 30 minutes positioned in the lower part of each section (Dale Hallmark, NPGCD, oral commun., 2014). NPGCD personnel measured the groundwater elevations before and after well development to ensure that the groundwater elevations had stabilized before sampling. USGS personnel again measured the groundwater elevation before the sampling procedure was started.

\section{Water-Quality Sample Collection and Processing}

Water-quality samples were collected and processed from each of the 30 wells. Quality-control samples were collected to assess bias and precision in sampling and processing procedures and included blanks, replicates, and spike samples. Water-quality samples were collected and processed in a mobile water-quality laboratory by following procedures outlined in the USGS National Field Methods manual (U.S. Geological Survey, variously dated). A Grundfos Redi-Flo3 submersible pump was lowered into each well and was attached to stainless steel pipe sections to pump the water directly from the wells to the Teflon tubing in the mobile water-quality laboratory for sample processing.

Each well was purged to ensure that samples collected for analysis were representative of the water in the aquifer. During the purging process, selected physical properties (dissolved oxygen, $\mathrm{pH}$, specific conductance, water temperature, turbidity, and alkalinity) were measured and recorded as the unfiltered water was purged from the well. The standard procedure of the USGS is to monitor these physical properties by using a multisensory probe installed in an airtight chamber (U.S. Geological Survey, variously dated) until readings for the physical properties stabilize. Because of equipment problems with the airtight chamber, an alternate method was used. Physical properties were measured in a 14-in. tall pump discharge container, which likely minimized errors in water temperature and dissolved-oxygen readings; because the airtight chamber could not be used, the dissolved-oxygen concentrations were flagged as estimated (E). Each well was purged of at least three well casing volumes of water or until all of the physical properties had stabilized (U.S. Geological Survey, variously dated).

Once the physical properties had stabilized, the well discharge was redirected to an enclosed processing chamber in the mobile water-quality laboratory where water samples were processed for analysis. Sample collection and preservation was completed in the processing chamber to prevent the introduction of airborne contaminants. The tubing and fittings used for collection and processing consisted of stainless steel or Teflon. The sample bottles used in the collection were composed of glass or prerinsed plastic. Sampling equipment was thoroughly cleaned after each well was sampled following standard USGS procedures (U.S. Geological Survey, variously dated). The stainless steel pipe sections used to lower the submersible pump into the well were washed between sites with a pressurized water spray and then rinsed with deionized water (a high-volume rinse). Pipe sections were capped at each end during transport to prevent airborne contamination when traveling. Samples for the analysis of major ions, trace elements, and nutrients were filtered through a 0.45 -micron $(\mu)$ capsule filter. Pesticide samples analyzed for pesticide and herbicide compounds were collected from 6 of the 30 wells during 2012; pesticide and herbicide compounds frequently detected in previous nationwide studies were targeted for sampling, as described in the "Previous Investigations" section of this report. All of the pesticide samples were filtered through a 142-millimeter $(\mathrm{mm})$ diameter glass fiber filter with a pore size of $0.70 \mu$. Samples that required refrigeration (nutrients and pesticides) were kept chilled at 4 degrees Celsius $\left({ }^{\circ} \mathrm{C}\right)$ and shipped chilled as soon as possible to the appropriate laboratory for analysis (table 2).

\section{Laboratory Analysis}

Water-quality samples were analyzed for major ions, nutrients, and trace elements at the National Water Quality Laboratory (NWQL), in Lakewood, Colo., and for selected pesticides at the NWQL, OGRL, or at both laboratories. Analytical methods are described in table 2 and results compiled in appendix 1. Pesticide samples were submitted to the NWQL for the analyses of 81 common pesticides and to the OGRL for analysis of 35 common pesticides. Glyphosate, AMPA, glufosinate, six acetamide parent compounds (acetochlor, alachlor, dimethenamid, flufenacet, metolachlor, and propachlor) and their associated degradation products were among the pesticides analyzed (app. 1). Parent pesticide compounds are those chemicals originally applied to crops. Acetochlor, alachlor, and metolachlor were analyzed by NWQL and OGRL.

Concentrations of major ions, nutrients, and trace elements were reported by the NWQL and reviewed by 
Table 2. Laboratory analysis and field preservation methods for physical properties and water-quality constituents measured in groundwater samples collected from monitor wells in the North Plains Groundwater Conservation District, Texas Panhandle, 2012-13.

[USGS, U.S. Geological Survey; NWQL, National Water Quality Laboratory; ICP-AES, inductively coupled plasma-atomic emission mass spectrometry; $\mu$ m, micrometer; <, less than; HNO, nitric acid; ICP-MS, inductively coupled plasma-mass spectrometry; cICP-MS, collision/reaction cell inductively coupled plasma-mass spectrometry; ${ }^{\circ} \mathrm{C}$, degrees Celsius; C-18, octadecyl; GC/MS, gas chromatography/ mass spectrometry; HPLC/MS, high-performance liquid chromatography/mass spectrometry; HPLC, high-performance liquid chromatography; OGRL, U.S. Geological Survey Organic Geochemistry Research Laboratory; mm, millimeter]

\begin{tabular}{|c|c|c|c|c|}
\hline $\begin{array}{l}\text { Constituent or } \\
\text { constituent group }\end{array}$ & $\begin{array}{l}\text { Analyzing } \\
\text { laboratory }\end{array}$ & $\begin{array}{l}\text { Analytical } \\
\text { method(s) }\end{array}$ & References & $\begin{array}{l}\text { Field preservation } \\
\text { procedure(s) }\end{array}$ \\
\hline Physical properties & Analyzed in the field & $\begin{array}{l}\text { USGS National field manual for the collec- } \\
\text { tion of water-quality data }\end{array}$ & $\begin{array}{l}\text { U.S. Geological Survey, variously } \\
\text { dated }\end{array}$ & None. \\
\hline Major ions & USGS NWQL & ICP-AES Ion chromatography & $\begin{array}{l}\text { American Public Health Association, } \\
\text { 1998; Fishman, 1993; Fishman and } \\
\text { Friedman, } 1989\end{array}$ & $\begin{array}{l}\text { Anions, filter through } 0.45-\mu \mathrm{m} \text { filter: } \\
\text { Cations, filter through } 0.45-\mu \mathrm{m} \text { filter, } \\
\text { acidify sample to } \mathrm{pH}<2 \text { with } \mathrm{HNO}_{3} \text {. }\end{array}$ \\
\hline Trace elements & USGS NWQL & ICP-AES, ICP-MS cICP-MS & $\begin{array}{l}\text { Fishman and Friedman, 1989; Garba- } \\
\text { rino, 1999; Garbarino and others, } \\
2006\end{array}$ & $\begin{array}{l}\text { Filter through } 0.45-\mu \mathrm{m} \text { filter, acidify } \\
\text { sample to } \mathrm{pH}<2 \text { with } \mathrm{HNO}_{3} \text {. }\end{array}$ \\
\hline Nutrients & USGS NWQL & Various methods & $\begin{array}{l}\text { Fishman, 1993; Patton and Kryskalla, } \\
\text { 2003; Patton and Kryskalla, } 2011\end{array}$ & $\begin{array}{l}\text { Filter through } 0.45-\mu \mathrm{m} \text { filter, chill and } \\
\text { maintain at } 4{ }^{\circ} \mathrm{C} \text {. }\end{array}$ \\
\hline $\begin{array}{l}\text { Pesticides and pesticide } \\
\text { degradates }\end{array}$ & USGS NWQL & $\begin{array}{l}\text { C-18 solid-phase extraction and capillary- } \\
\text { column GC/MS and HPLC/MS }\end{array}$ & $\begin{array}{l}\text { Zaugg and others, 1995; Lindley and } \\
\text { others, 1996; Madsen and others, } \\
\text { 2003; Sandstrom and others, } 2001\end{array}$ & $\begin{array}{l}\text { Filter through } 142-\mathrm{mm} \text { baked glass fiber } \\
\text { filter, chill sample and maintain at } 4{ }^{\circ} \mathrm{C} \text {. }\end{array}$ \\
\hline $\begin{array}{l}\text { Glyphosate herbicides } \\
\text { and degradates, and } \\
\text { Glufosinate herbicides }\end{array}$ & USGS OGRL & $\begin{array}{l}\text { Isotope dilution and online solid-phase } \\
\text { extraction and liquid chromatography/tan- } \\
\text { dem mass spectrometry }\end{array}$ & Meyer and others, 2009 & $\begin{array}{l}\text { Filter through } 142-\mathrm{mm} \text { baked glass fiber } \\
\quad \text { filter, chill sample and maintain at } 4{ }^{\circ} \mathrm{C} \text {. }\end{array}$ \\
\hline $\begin{array}{l}\text { Acetamide herbicides and } \\
\text { degradates }\end{array}$ & USGS OGRL & Online solid-phase extraction and HPLC & Lee and Strahan, 2003 & $\begin{array}{l}\text { Filter through } 142-\mathrm{mm} \text { baked glass fiber } \\
\text { filter, chill sample and maintain at } 4^{\circ} \mathrm{C} \text {. }\end{array}$ \\
\hline
\end{tabular}


project personnel for completeness and accuracy. The analytical quantification procedure used by the NWQL for reporting results is based on the long-term method detection level (LT-MDL) and laboratory reporting level (LRL). The LT-MDL concentrations are defined as a censoring limit for most analytical methods at the NWQL, and its purpose is to limit the false positive rate to less than or equal to 1 percent (Childress and others, 1999). An LT-MDL is a modification of the U.S. Environmental Protection Agency (EPA) definition of the method detection limit (MDL) (U.S. Environmental Protection Agency, 1992). The LRL is defined as twice the LT-MDL and is established to limit the occurrence of false negative detections to less than or equal to 1 percent (Childress and others, 1999). A constituent concentration is considered estimated by the laboratory when results are greater than the LT-MDL and less than the LRL; that is, detection is considered likely, but quantitation is considered questionable. The remark code of "E" (estimated) is assigned by the laboratory for these results. When the measured values were greater than the calibration range of the instrument or when the field measurement stabilization criteria were not met, the data are reported with an "E" remark code (Childress and others, 1999). In rare instances, a value lower than the LT-MDL might be reported by the analyst. In contrast to the LT-MDL and LRL reporting convention used by the NWQL, the OGRL uses one reporting limit for each constituent that is set equal to or greater than the limit of quantitation (Michael Meyer, Organic Chemistry Research Laboratory, oral commun., 2014).

\section{Quality Assurance}

Quality-control samples were collected to assess for possible bias and variability introduced during sample collection, processing, and analysis. The quality-control samples consisted of blank samples ( 3 field blanks, 1 equipment blank, 3 high-volume rinse-water solution blanks [rinse-water blanks], and 1 ambient blank) (tables 3 and 4), 3 replicate samples (app. 2, back of this report), and 1 matrixspike sample (table 5). Blank samples are used to determine the magnitude of contaminant concentration (for analytes of specific interest) that might have been introduced into the sample as a result of sampling-related activities (U.S. Geological Survey, variously dated). Field blanks are blankwater samples subjected to all aspects of sample collection, field-processing preservation, transportation, and laboratory handling as an environmental sample. Equipment blanks are blank-water samples processed through some or all equipment used for collecting and processing as an environmental sample. Equipment blanks are similar to field blanks but processed under controlled office conditions to identify only contamination that might be introduced from the sampling equipment. Ambient blanks are blank-water samples that are poured into the same types of bottles used to collect the environmental samples; they are kept with the set of sample bottles before sample collection and opened at the sampling site and exposed to the ambient conditions (Wilde and others, 2010). In addition to the quality-control samples collected in the field, the NWQL and the OGRL analyze additional qualitycontrol samples during laboratory analysis, including sets of blank, duplicate, and spike samples (not presented in this report). The NWQL adds two surrogates, diazinon-d10 and alpha-HCH-6, to each environmental sample before sample processing to monitor method reliability for each sample. Each surrogate is an analyte not expected to be present in any environmental sample. The percent recoveries for diazinon d10 ranged from 84.7 to 109.7 percent and for alpha-HCH-6 from 82.0 to 96.8 percent and were considered to be acceptable percent recoveries.

Three of the blank-water sample types (field blanks, equipment blanks, and the ambient blanks) were prepared by using quality-assured blank water-water with extremely low concentrations of constituents prepared and tested by the NWQL (Wilde, 2004). Inorganic-grade blank water was used for blanks that were analyzed for major ions, trace elements, and nutrients. Pesticide-grade blank water was used for blanks that were analyzed for pesticide compounds. The tubing inserted into the well and into the sample chamber for sample collection required large volumes of water as a final step in the cleaning process, which was completed between sites to prevent cross-sample contamination. Rinse water for this step of the sample processing was brought from the USGS Field Office in Wichita Falls, Tex., or obtained locally from a private source. Two rinse-water blanks were processed with the equipment rinse water obtained from the local water source in Amarillo, Tex., and one rinse-water blank was processed with water produced with the water purifying system at the USGS Field Office in Wichita Falls. A summary of the constituents detected in field blanks, equipment blanks, and rinse-water blanks is provided in tables 3 and 4 .

During the first year of sampling in 2012, two field blanks were collected. Major ions, nutrients, trace elements, and pesticides were analyzed for with first field blank collected on March 4, 2012. Detected constituents (constituents measured in filtered water samples) were ammonia $(0.012 \mathrm{mg} / \mathrm{L})$, cobalt $(0.077$ micrograms per liter $[\mu \mathrm{g} / \mathrm{L}])$, manganese $(0.15 \mu \mathrm{g} / \mathrm{L})$, and one pesticide, tefluthrin $(0.005 \mu \mathrm{g} / \mathrm{L})$; tefluthrin was reported as an estimated concentration less than the LT-MDL of $0.014 \mu \mathrm{g} / \mathrm{L}$. The second equipment blank, which was collected on March 6, 2012, was not analyzed for pesticides. The following dissolved constituents were detected in the March 6, 2012, field blank: calcium $(0.090 \mathrm{mg} / \mathrm{L})$, magnesium $(0.011$ $\mathrm{mg} / \mathrm{L})$, manganese $(0.39 \mu \mathrm{g} / \mathrm{L})$, molybdenum $(0.017 \mu \mathrm{g} / \mathrm{L})$, nickel $(0.11 \mu \mathrm{g} / \mathrm{L})$, strontium $(0.62 \mu \mathrm{g} / \mathrm{L})$, and vanadium $(0.09$ $\mu \mathrm{g} / \mathrm{L})$. In the third field blank, collected on March 27, 2013, low concentrations were detected of calcium $(0.077 \mathrm{mg} / \mathrm{L})$, magnesium $(0.016 \mathrm{mg} / \mathrm{L})$, estimated fluoride $(0.08 \mathrm{mg} / \mathrm{L})$, silica $(0.021 \mathrm{mg} / \mathrm{L})$, barium $(0.18 \mu \mathrm{g} / \mathrm{L})$, cobalt $(0.302 \mu \mathrm{g} / \mathrm{L})$, lead $(0.050 \mu \mathrm{g} / \mathrm{L})$, manganese $(0.54 \mu \mathrm{g} / \mathrm{L})$, strontium $(1.00 \mu \mathrm{g} / \mathrm{L})$, vanadium $(0.08 \mu \mathrm{g} / \mathrm{L})$, and zinc $(1.8 \mu \mathrm{g} / \mathrm{L})$.

An equipment blank was collected and processed in the USGS South Texas Program office located in San Antonio, 
Table 3. Water-quality constituents detected in quality-assurance samples collected from monitor wells in the North Plains Groundwater Conservation District, Texas Panhandle, 2012-13.

[Shading indicates National Water Quality Laboratory reporting level for LT-MDL and LRL changed September 30, 2012. NWQL, National Water Quality Laboratory; mg/L, milligrams per liter; <, less than; $\mu \mathrm{g} / \mathrm{L}$, micrograms per liter; E, estimated]

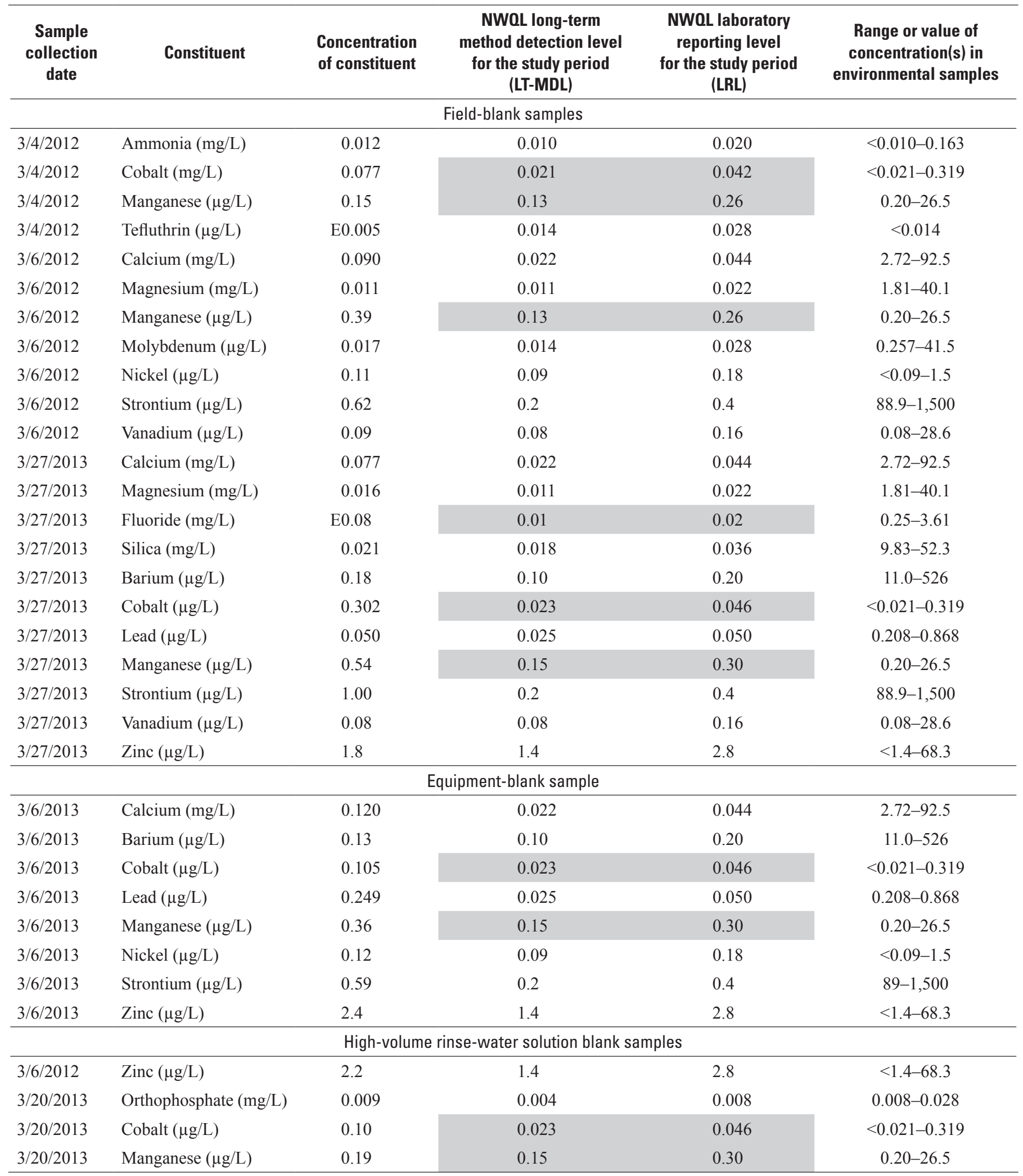


Table 4. Summary of blank-water sample results associated with samples collected from monitor wells in the North Plains Groundwater Conservation District, Texas Panhandle, 2012-13.

[Shading indicates National Water Quality Laboratory reporting level for LT-MDL and LRL changed September 30, 2012. NWQL, National Water Quality Laboratory; mg/L, milligrams per liter; NA, not available; $\mu \mathrm{g} / \mathrm{L}$, micrograms per liter; E, estimated; <, less than]

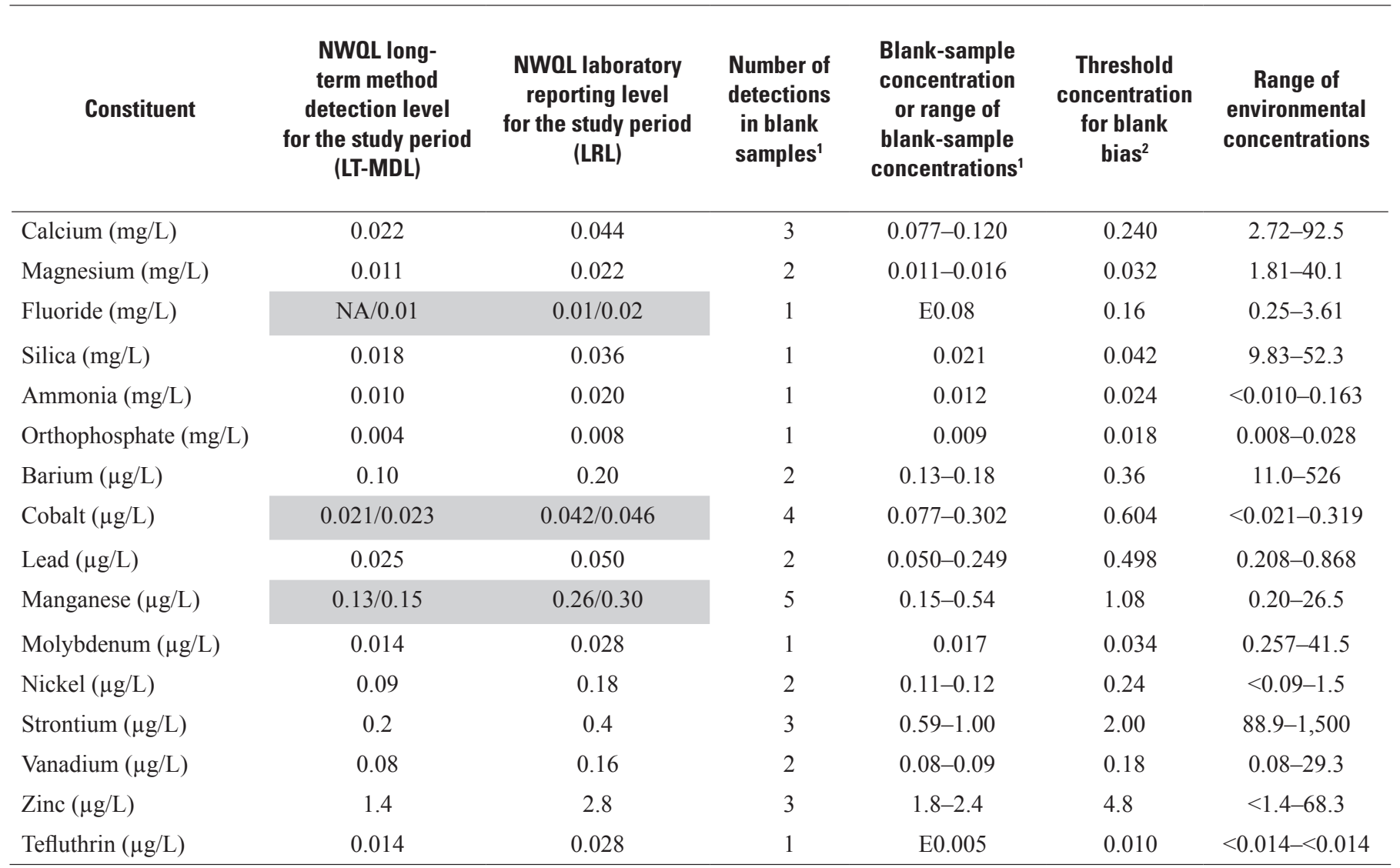

${ }^{1}$ Field-blank samples, equipment-blank samples, and high-volume rinse-water solution blank samples.

${ }^{2}$ Calculated as two times the largest blank-sample concentration.

Tex., where the field sampling equipment is stored to determine if the equipment used for sample collection would introduce any bias or variability to the data. The sample was collected before the 2013 field sampling. Inorganic blank water was processed through the sampling equipment and analyzed for major ions, nutrients, and trace metals. The following constituents were detected: calcium $(0.120 \mathrm{mg} / \mathrm{L})$, barium $(0.13 \mu \mathrm{g} / \mathrm{L})$, cobalt $(0.105 \mu \mathrm{g} / \mathrm{L})$, lead $(0.249 \mu \mathrm{g} / \mathrm{L})$, manganese $(0.36 \mu \mathrm{g} / \mathrm{L}), \operatorname{nickel}(0.12 \mu \mathrm{g} / \mathrm{L})$, strontium $(0.59 \mu \mathrm{g} / \mathrm{L})$, and zinc $(2.4 \mu \mathrm{g} / \mathrm{L})$. Although the concentrations of these eight constituents are low, environmental sample concentrations at low levels could be affected by the small amounts of these constituents introduced while the environmental sample is in contact with the sampling equipment.

Environmental concentrations were compared to blank concentrations for constituents detected in any type of blank sample (table 4). The number of blank samples with detections and the range of concentrations measured in the blank samples were then compared to an arbitrary threshold concentration set for each constituent. This threshold was set as two times the largest concentration measured in a blank sample. When a concentration for a given constituent in an environmental sample was smaller than the threshold concentration, it was determined that sample collection and processing might have contributed appreciably to that concentration thus biasing the environmental sample result. Environmental sample concentrations for ammonia, orthophosphate, cobalt, lead, manganese, nickel, vanadium, and zinc were detected that were less than the threshold concentrations listed (table 4), and therefore, might have been biased by small amounts of contamination introduced during sample collection and processing. Tefluthrin (a synthetic pyrethroid pesticide 
that was first introduced in 1986 and is synthesized from the flower heads of Chrysanthemum cinerariifolium [Gilbert, 2013; U.S. Department of Health and Human Services, 2003]) was the only pesticide detected in a pesticide-grade blankwater sample. The detected tefluthrin concentration (only one blank sample was submitted for analysis) was less than the LT-MDL of $0.014 \mu \mathrm{g} / \mathrm{L}$ (estimated value of $0.005 \mu \mathrm{g} / \mathrm{L}$ ) (table 4). Tefluthrin was not detected in any of the environmental samples. On an overall basis, data from the blank samples indicate that sample collection and processing activities caused minimal contamination of samples and only when the environmental sample constituent concentration was close to the LT-MDL.

Rinse-water blanks were used to document the purity of the rinse water used to clean the sampling equipment. Because of the large amounts of water necessary to clean (pretreat) the well pipe sections, the use of inorganic-blank water and pesticide-blank water would have been cost prohibitive, and deionized water was used instead. A rinse-water blank prepared on October 17, 2012, by using deionized water from the USGS Field Office in Wichita Falls was analyzed for major ions and trace metals; this rinse-water blank had no detections greater than the applicable LT-MDLs set by the NWQL. The rinse-water blanks prepared by using deionized water obtained from a local water source in Amarillo, Tex., were analyzed for major ions, nutrients, and trace metals analyses. One of these rinse-water blanks was collected on March 6, 2012, and the second was collected on March 20, 2013. For the rinse-water blank collected on March 6, 2012, only zinc $(2.2 \mu \mathrm{g} / \mathrm{L})$ was detected at a concentration greater than the LT-MDL of $1.4 \mu \mathrm{g} / \mathrm{L}$. Orthophosphate $(0.009 \mathrm{mg} / \mathrm{L})$, cobalt $(0.10 \mu \mathrm{g} / \mathrm{L})$, and manganese $(0.19 \mu \mathrm{g} / \mathrm{L})$ were detected at concentrations greater than the LT-MDL (table 3 ) in the rinse-water blank collected on March 20, 2013.

Ambient blanks were collected to determine if the sample was affected by exposure to atmospheric conditions such as dust when a sample is collected. On March 28, 2013, an ambient blank was collected by filling a bottle with pesticide-blank water in the same type of bottle used for an environmental sample, opened in the processing chamber when the environmental samples were processed, and exposed to the ambient conditions in the mobile laboratory. The ambient blank sample was analyzed for glyphosate, AMPA, and glufosinate, and none of these constituents were detected (because there were no detections, results from ambient blanks are not shown in table 3).

Replicate samples were collected to identify any variability in the analytical results that might have been introduced during sampling and analysis. For this study, sequential replicate samples were collected; samples were collected consecutively with the environmental sample collected first, followed by the replicate sample. Precision is calculated from two replicate samples, expressed as relative percent difference $(R P D)$ :

$$
\left.R P D=\left|C_{1}-C_{2}\right| /\left(\left(C_{1}+C_{2}\right) / 2\right)\right) \times 100
$$

where

$R P D \quad$ is relative percent difference, in percent;

$C_{1} \quad$ is the detected concentration in the environmental sample, in milligrams per liter or micrograms per liter; and

$C_{2} \quad$ is the detected concentration in the replicate sample, in milligrams per liter or micrograms per liter.

When there is no difference between the paired analyses, the RPD is zero percent. All RPDs were rounded to one-tenth of 1 percent. The RPD was not calculated if one or both of the paired replicate concentrations were less than the LRL or identified as an estimated value by the laboratory (app. 2). RPDs less than or equal to 10 percent were used to indicate good agreement between the environmental and replicate sample results when concentrations were sufficiently large when compared to the LRL. A threshold concentration of two times the largest blank concentration was used to define concentrations sufficiently large when compared to the LRL to warrant possible concerns about sample contamination and additional scrutiny of environmental sample.

Three replicate samples were collected for this study. Two replicates were collected in 2012 and one in 2013. The replicate samples were analyzed for major ions, nutrients, trace elements, and pesticides. The first replicate sample was collected on February 28, 2012, at well Mo-2351 in Moore County (fig. 1). In all environmental and replicate samples, concentrations of pesticides and pesticide degradates were less than the LRL (app. 2). The constituents with a RPD greater than 10 percent in the February 28, 2012, replicate analyses were lead (44.7 percent), manganese (15.7 percent), and zinc (25.8 percent). The second replicate was collected March 5, 2012, at well Li-0582 in Lipscomb County; the only constituents in the March 2012 replicate analyses with an RPD greater than 10 percent were lead ( 56.9 percent) and antimony (11.5 percent). The third replicate was collected March 20, 2013, at well Mo-2319 in Moore County. The constituents with a RPD greater than 10 percent were cobalt ( 81.0 percent), lithium (15.7 percent), manganese (50.0 percent), and nickel (40.0 percent). The large RPDs for cobalt, manganese, and nickel were an artifact of the small concentrations of these metals that were measured-cobalt (environmental sample $0.059 \mu \mathrm{g} / \mathrm{L}$; replicate sample $0.025 \mu \mathrm{g} / \mathrm{L})$, nickel (environmental sample $0.33 \mu \mathrm{g} / \mathrm{L}$; replicate sample 0.22 $\mu \mathrm{g} / \mathrm{L}$ ), and manganese (environmental sample $0.35 \mu \mathrm{g} / \mathrm{L}$; replicate sample $0.21 \mu \mathrm{g} / \mathrm{L})$. The concentrations of cobalt, manganese, and nickel in the environmental and replicate samples were only slightly greater than the LRLs. In general, RPD values for the constituents indicated that the amount of variability between the environmental and replicate samples were less than 10 percent, indicating good agreement between the environmental and replicate sample results. 
Becker and others (2002) investigated the quality of groundwater in the central High Plains aquifer and found that atrazine and metolachlor were the two most frequently detected pesticides. Table 5 lists the most frequently detected analytes by Becker and others (2002) and the associated recovery rates from the matrix sample submitted for this study.

Between January 1, 2012, and March 31, 2013, the NWQL analyzed 290 pesticide-grade blank-water samples spiked with known surrogate concentrations to determine percent recoveries of these constituents; the results from the analyses of the spiked samples are summarized in table 5 . Between January 1, 2012, and March 31, 2012, the OGRL also analyzed 18 high-quality pesticide-grade blank-water samples spiked with known surrogate concentrations to determine percent recoveries of these constituents; those results also are summarized in table 5. Analytical recoveries of the spiked compounds are expressed in percent of the expected concentrations. The 95-percent confidence interval (lower and upper values) for the recovery of constituents that occurred frequently in the study by Becker and others (2002) are listed in table 5. For example, the 95-percent confidence interval for atrazine recovery was 90.5 to 98.2 percent, which means that 95 times out of 100 the laboratory will recover between 90.5 and 98.2 percent of the added atrazine. The 95-percent confidence interval for tebuthiuron recovery in blank samples was 126 to 153 percent and 118 to 124 percent for CIAT recovery (table 5).

Environmental-matrix spikes are environmental samples collected and spiked in the field with a known quantity of analytes to indicate the effect that the sample matrix might have on the concentration measurement of a constituent present in the sample (Mueller and others, 1997). One environmental-matrix sample was collected on March 7, 2012, at well Li-0656 in Lipscomb County and spiked with pesticide compounds to evaluate analytical recoveries and matrix interference.

The spiked concentrations of selected pesticide compounds in the environmental sample and the corresponding concentrations in the unspiked sample are reported, as well as the percent recoveries for the spiked compounds. Because there were no detections of these pesticide compounds in the unspiked environmental sample, it was important to rule out the possibility of matrix interference. The percent recoveries for the pesticide compounds in the spiked environmental sample indicate matrix interference was unlikely (table 5).

\section{Depth to Groundwater and Groundwater Elevations}

The depth to groundwater and groundwater elevation data provide useful information for characterizing the water quality in the study area. The highest land-surface elevation at a sampling site was recorded in the western part of the study area in Dallam County at well Da-3588 (4,418 ft, WGS 84 ), and the lowest land-surface elevations were recorded in the eastern part of the study area in Lipscomb County at wells Li-3687 (2,472 ft) and Li-0567 (2,473 ft, WGS 84). Depth to groundwater ranged from $76.60 \mathrm{ft}$ at well Li-0613 in Lipscomb County to $480.8 \mathrm{ft}$ at well Ha-2583 in Hartley County. Sampling depths from land surface ranged from $120 \mathrm{ft}$, measured at well Li-0613, to $500 \mathrm{ft}$, measured at well Ha-2583. Groundwater elevations in the Ogallala Formation ranged from 2,279 ft in well Li-3687 to 4,160 ft in well Da-3588 (table 1).

\section{Water Quality}

After measuring groundwater-level elevations, selected physical properties were measured in the field, and waterquality samples were collected and processed at each of the 30 wells that were part of the study. Physical properties measured onsite were dissolved oxygen, $\mathrm{pH}$, specific conductance, water temperature, turbidity, and alkalinity. Water-quality samples were collected for analysis of dissolved solids, major ions, nutrients and trace elements at the NWQL (table 6, app. 1). Water-quality samples also were collected for analysis of selected pesticides at the NWQL or OGRL (tables 7-8, app. 1). Data for physical properties, dissolved solids, major ions, nutrients, and trace elements are summarized in table 6 and listed in appendix 1. Data for pesticides are summarized in table 8 and listed in appendix 1 . Results from the waterquality analyses were compared to the available National Primary Drinking Water Regulations established by the EPA (hereinafter referred to as the "maximum contaminant levels" or "MCLs"). Results from water-quality analyses were also compared to National Secondary Drinking Water Regulations (secondary drinking-water standards), which are non-enforceable guidelines, to Texas Risk Reduction Program (TRRP) protective concentration levels established for residential groundwater in Texas, or both (U.S. Environmental Protection Agency, 2013; Texas Commission on Environmental Quality, 2012).

\section{Physical Properties and Major lons}

The median dissolved-oxygen concentration was $7.6 \mathrm{mg} / \mathrm{L}$ (table 6), which was greater than the median dissolved-oxygen concentration of $6.2 \mathrm{mg} / \mathrm{L}$ reported by Becker and others (2002) or the median dissolved-oxygen concentration of $6.7 \mathrm{mg} / \mathrm{L}$ reported by Bruce and others (2003). Low dissolved-oxygen concentrations were measured in two wells in Dallum County, Da-3589 $(0.1 \mathrm{mg} / \mathrm{L})$ and Da-3588 (1.2 mg/L) (app. 1). Bruce and others (2003) state that suboxic (less than $1.0 \mathrm{mg} / \mathrm{L}$ ) concentrations of dissolved oxygen can affect the concentration of other dissolved 
Table 5. Measured concentrations and 95-percent confidence intervals for the recovery of pesticides determined by using spiked and unspiked environmental samples collected from monitor wells in the North Plains Groundwater Conservation District, Texas Panhandle, 2012.

[NWQL, National Water Quality Laboratory; $\mu \mathrm{g} / \mathrm{L}$, micrograms per liter; E, estimated; CIAT, 2-Chloro-4-isopropylamino-6-amino-s-triazine; OGRL, U.S. Geological Survey Organic Geochemistry Research Laboratory; NA, not available; AMPA, Aminomethylphosphonic Acid]

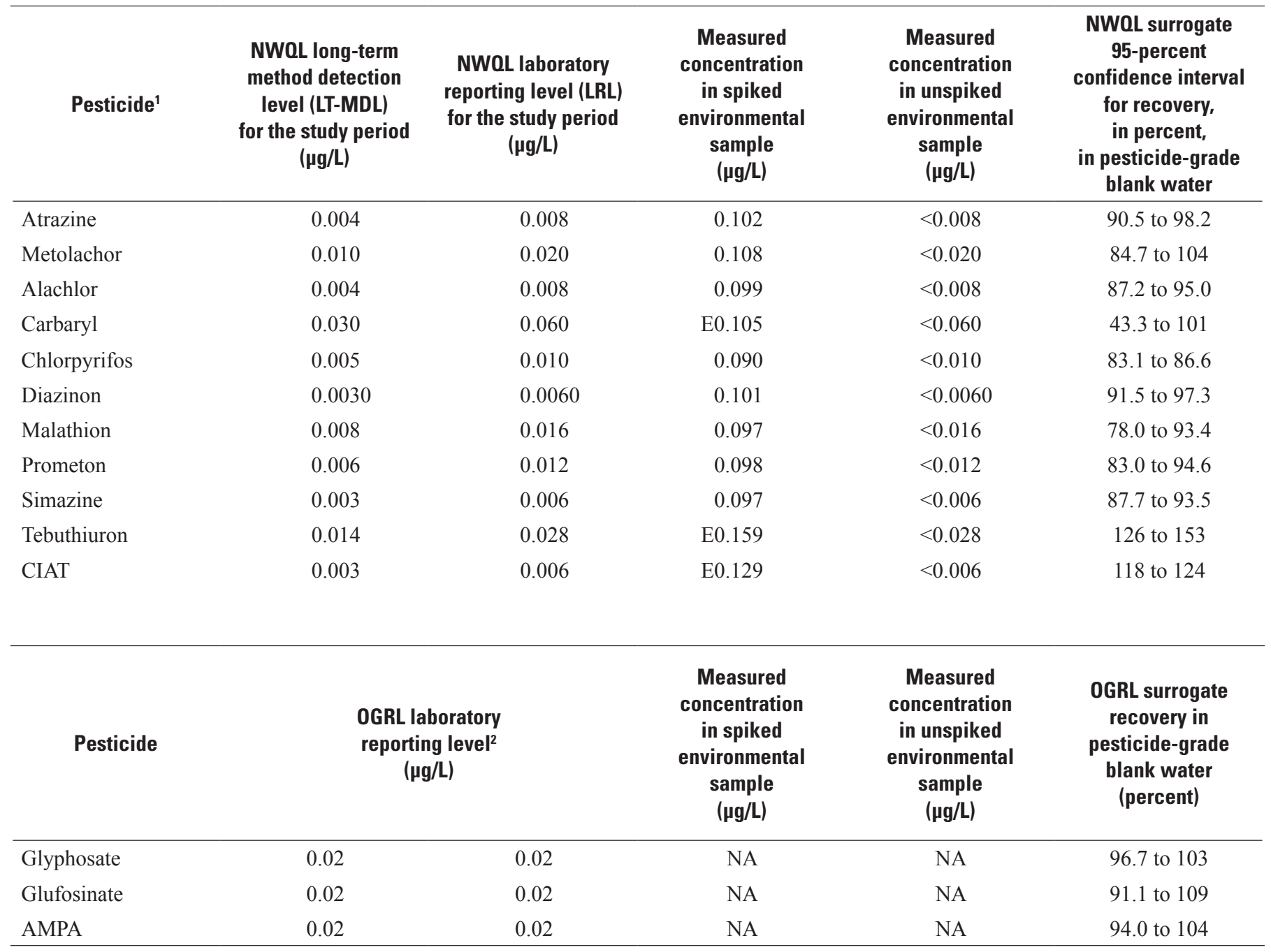

${ }^{1}$ Listed from most frequently detected to least frequently detected as reported by Becker and others (2002), for groundwater-quality samples collected from the central High Plains aquifer.

${ }^{2}$ OGRL uses one reporting level that is equal to or greater than the limit of quantitation (Michael Meyer, OGRL, oral commun., 2014). 
Table 6. Summary statistics for physical properties, dissolved solids, major ions, nutrients, and trace elements measured in samples collected from 30 monitor wells in the North Plains Groundwater Conservation District, Texas Panhandle, 2012-13.

[Shading indicates National Water Quality Laboratory reporting level for long-term method detection level (LT-MDL) and laboratory reporting level (LRL) changed September 30, 2012. NWQL, National Water Quality Laboratory; mg/L, milligrams per liter; --, no data; E, estimated; MCL, maximum contaminant level; TRRP, Texas Risk Reduction Program; pcl, protective concentration level; ${ }^{\circ} \mathrm{C}$, degrees Celsius; $\mu \mathrm{S} / \mathrm{cm}$, microsiemens per centimeter; NTRU nephelometric turbidity ratio units; $\mathrm{CaCO}_{3}$, calcium carbonate; NA, not available; <, less than; +, plus; $\mu \mathrm{g} / \mathrm{L}$, micrograms per liter]

\begin{tabular}{|c|c|c|c|c|c|c|c|c|c|c|}
\hline Constituents & $\begin{array}{l}\text { Samples } \\
\text { collected }\end{array}$ & $\begin{array}{l}\text { NWQL long-term } \\
\text { method detection level } \\
\text { for the study period } \\
\text { (LT-MDL) }\end{array}$ & $\begin{array}{l}\text { NWOL reporting } \\
\text { level for the } \\
\text { study period } \\
\text { (LRL) }\end{array}$ & Minimum & $\begin{array}{c}\text { 25th } \\
\text { percentile }^{1}\end{array}$ & Mean & Median & $\begin{array}{c}\text { 75th } \\
\text { percentile }{ }^{2}\end{array}$ & Maximum & $\begin{array}{c}\text { MCL, }^{3} \\
\text { secondary } \\
\text { drinking- } \\
\text { water } \\
\text { standard, or } \\
\text { TRRP pcl }\end{array}$ \\
\hline \multicolumn{11}{|c|}{ Physical properties } \\
\hline Dissolved oxygen (mg/L) & 30 & -- & -- & E0.1 & E6.6 & E7.1 & E7.6 & E8.3 & E9.2 & -- \\
\hline pH (standard units) & 30 & -- & 0.1 & 7.3 & 7.5 & 7.6 & 7.6 & 7.7 & 8.7 & $\neq 6.5-8.5$ \\
\hline $\begin{array}{l}\text { Specific conductance }(\mu \mathrm{S} / \mathrm{cm} \\
\left.\text { at } 25^{\circ} \mathrm{C}\right)\end{array}$ & 30 & -- & 5 & 379 & 452 & 569 & 497 & 654 & 1,230 & -- \\
\hline Water temperature $\left({ }^{\circ} \mathrm{C}\right)$ & 30 & -- & -- & 11.7 & 17.5 & 18 & 18 & 18.7 & 20.4 & -- \\
\hline Turbidity, (NTRU) & 30 & -- & -- & 0.1 & 0.1 & 0.4 & 0.3 & 0.5 & 2.0 & -- \\
\hline Alkalinity as $\mathrm{CaCO}_{3}(\mathrm{mg} / \mathrm{L})$ & 30 & -- & 1 & 110 & 182 & 199 & 195 & 210 & 302 & -- \\
\hline \multicolumn{11}{|c|}{ Dissolved solids and major ions } \\
\hline Dissolved solids (mg/L) & 30 & -- & 20 & 251 & 294 & 359 & 310 & 400 & 741 & $* 500$ \\
\hline Calcium (mg/L) & 30 & 0.022 & 0.044 & 2.72 & 35.7 & 43.4 & 41.8 & 50.0 & 92.5 & -- \\
\hline Magnesium (mg/L) & 30 & 0.011 & 0.022 & 1.81 & 22.1 & 24.1 & 26.3 & 29.2 & 40.1 & -- \\
\hline Potassium (mg/L) & 30 & 0.03 & 0.06 & 2.53 & 3.84 & 4.85 & 4.82 & 5.76 & 7.36 & -- \\
\hline $\begin{array}{l}\text { Sodium-adsorption ratio } \\
\text { (dimensionless) }\end{array}$ & 30 & -- & -- & 0.22 & 0.55 & 0.85 & 0.62 & 1.46 & 23.4 & -- \\
\hline Sodium (mg/L) & 30 & 0.06 & 0.12 & 7.12 & 18.6 & 42.1 & 21.2 & 44.9 & 203 & -- \\
\hline Bromide (mg/L) & 30 & 0.010 & 0.020 & 0.036 & 0.096 & 0.154 & 0.120 & 0.154 & 0.540 & -- \\
\hline Chloride (mg/L) & 30 & 0.06 & 0.12 & 4.15 & 7.33 & 35.4 & 11.6 & 26.0 & 237 & $* 250$ \\
\hline Fluoride (mg/L) & 30 & $\mathrm{NA} / 0.01$ & $0.010 / 0.02$ & 0.25 & 0.89 & 1.23 & 1.14 & 1.50 & 3.61 & 4.0 \\
\hline Silica (mg/L) & 30 & 0.018 & 0.036 & 9.83 & 26.6 & 32.1 & 30.4 & 35.1 & 52.3 & -- \\
\hline Sulfate $(\mathrm{mg} / \mathrm{L})$ & 30 & 0.09 & 0.18 & 5.84 & 24.0 & 40.2 & 37.1 & 50.5 & 138 & $* 250$ \\
\hline \multicolumn{11}{|c|}{ Nutrients } \\
\hline Ammonia (mg/L) & 30 & 0.010 & 0.020 & $<0.010$ & $<0.010$ & $<0.010$ & $<0.010$ & $<0.010$ & 0.163 & -- \\
\hline Nitrite plus nitrate (mg/L) & 30 & 0.040 & 0.080 & $<0.040$ & 1.52 & 2.70 & 2.05 & 2.86 & 11.6 & 10 \\
\hline Nitrite $(\mathrm{mg} / \mathrm{L})$ & 30 & 0.001 & 0.002 & $<0.001$ & $<0.001$ & $<0.001$ & $<0.001$ & $<0.001$ & 0.001 & 1.0 \\
\hline Orthophosphate (mg/L) & 30 & 0.004 & 0.008 & 0.008 & 0.011 & 0.014 & 0.014 & 0.018 & 0.028 & -- \\
\hline $\begin{array}{l}\text { Total nitrogen (nitrite }+ \\
\quad \text { nitrate }+ \text { ammonia }+ \\
\text { organic nitrogen })(\mathrm{mg} / \mathrm{L})\end{array}$ & 30 & 0.05 & 0.10 & 0.14 & 1.59 & 2.76 & 2.14 & 2.88 & 11.1 & -- \\
\hline
\end{tabular}


Table 6. Summary statistics for physical properties, dissolved solids, major ions, nutrients, and trace elements measured in samples collected from 30 monitor wells in the North Plains Groundwater Conservation District, Texas Panhandle, 2012-13.-Continued

[Shading indicates National Water Quality Laboratory reporting level for long-term method detection level (LT-MDL) and laboratory reporting level (LRL) changed September 30, 2012. NWQL, National Water Quality Laboratory; mg/L, milligrams per liter; --, no data; E, estimated; MCL, maximum contaminant level; TRRP, Texas Risk Reduction Program; pcl, protective concentration level; ${ }^{\circ} \mathrm{C}$, degrees Celsius; $\mu \mathrm{S} / \mathrm{cm}$, microsiemens per centimeter; NTRU nephelometric turbidity ratio units; $\mathrm{CaCO}_{3}$, calcium carbonate; NA, not available; $<$, less than; +, plus; $\mu \mathrm{g} / \mathrm{L}$, micrograms per liter]

\begin{tabular}{|c|c|c|c|c|c|c|c|c|c|c|}
\hline Constituents & $\begin{array}{l}\text { Samples } \\
\text { collected }\end{array}$ & $\begin{array}{l}\text { NWQL long-term } \\
\text { method detection level } \\
\text { for the study period } \\
\text { (LT-MDL) }\end{array}$ & $\begin{array}{l}\text { NWOL reporting } \\
\text { level for the } \\
\text { study period } \\
\text { (LRL) }\end{array}$ & Minimum & $\begin{array}{c}\text { 25th } \\
\text { percentile }^{1}\end{array}$ & Mean & Median & $\begin{array}{c}\text { 75th } \\
\text { percentile }\end{array}$ & Maximum & $\begin{array}{c}\text { MCL, }^{3} \\
\text { secondary } \\
\text { drinking- } \\
\text { water } \\
\text { standard, or } \\
\text { TRRP pcl }\end{array}$ \\
\hline \multicolumn{11}{|c|}{ Trace elements } \\
\hline Aluminum $(\mu \mathrm{g} / \mathrm{L})$ & 30 & 2.2 & 4.4 & $<2.2$ & $* * 0.6$ & $* * 2.4$ & $* * 1.3$ & $* * 2.6$ & 24.4 & $* 50-200$ \\
\hline Barium $(\mu \mathrm{g} / \mathrm{L})$ & 30 & 0.10 & 0.20 & 11.0 & 56.6 & 124 & 83.8 & 159 & 526 & 2,000 \\
\hline Beryllium $(\mu \mathrm{g} / \mathrm{L})$ & 30 & 0.006 & 0.012 & $<0.006$ & $* * 0.002$ & $* * 0.005$ & $* * 0.004$ & $* * 0.006$ & 0.021 & 4 \\
\hline Cadmium $(\mu \mathrm{g} / \mathrm{L})$ & 30 & 0.016 & 0.032 & $<0.016$ & $* * 0.005$ & $* * 0.017$ & $* * 0.010$ & $* * 0.019$ & 0.110 & 5 \\
\hline Chromium $(\mu \mathrm{g} / \mathrm{L})$ & 30 & 0.07 & 0.14 & $<0.07$ & $* * 0.8$ & $* * 1.4$ & $* * 1.6$ & $* * 1.9$ & 2.7 & 100 \\
\hline Cobalt $(\mu \mathrm{g} / \mathrm{L})$ & 30 & $0.021 / 0.023$ & $0.042 / 0.046$ & $<0.021$ & $* * 0.029$ & $* * 0.070$ & $* * 0.045$ & $* * 0.076$ & 0.319 & -- \\
\hline Copper $(\mu \mathrm{g} / \mathrm{L})$ & 30 & 0.80 & 1.60 & $<0.80$ & $* * 0.5$ & $* * 0.7$ & $* * 0.6$ & $* * 0.8$ & 1.3 & 1,300 \\
\hline Iron $(\mu \mathrm{g} / \mathrm{L})$ & 30 & $3.2 / 4.0$ & $6.4 / 8.0$ & $<4.0$ & $<4.0$ & $<4.0$ & $<4.0$ & $<4.0$ & 9.4 & *300 \\
\hline Lead $(\mu \mathrm{g} / \mathrm{L})$ & 30 & 0.025 & 0.050 & 0.208 & 0.309 & 0.459 & 0.438 & 0.583 & 0.868 & 15 \\
\hline Lithium $(\mu \mathrm{g} / \mathrm{L})$ & 30 & 0.22 & 0.44 & 20.8 & 34.9 & 49.8 & 45.0 & 61.5 & 105 & $\uparrow 49$ \\
\hline Manganese $(\mu \mathrm{g} / \mathrm{L})$ & 30 & $0.13 / 0.15$ & $0.26 / 0.30$ & 0.20 & 0.34 & 1.83 & 0.48 & 0.70 & 26.5 & $* 50$ \\
\hline Molybdenum ( $\mu \mathrm{g} / \mathrm{L})$ & 30 & 0.014 & 0.028 & 0.257 & 3.55 & 7.08 & 5.86 & 7.12 & 41.5 & $\dagger 120$ \\
\hline Nickel $(\mu \mathrm{g} / \mathrm{L})$ & 30 & 0.09 & 0.18 & $<0.09$ & 0.19 & 0.29 & 0.25 & 0.32 & 1.5 & $\uparrow 490$ \\
\hline Silver $(\mu \mathrm{g} / \mathrm{L})$ & 30 & 0.005 & 0.010 & $<0.005$ & $* * 0.001$ & $* * 0.002$ & $* * 0.002$ & $* * 0.003$ & 0.011 & $* 100$ \\
\hline Strontium $(\mu \mathrm{g} / \mathrm{L})$ & 30 & 0.2 & 0.4 & 88.9 & 915 & 974 & 1,040 & 1,140 & 1,500 & $\uparrow 15,000$ \\
\hline Thallium $(\mu \mathrm{g} / \mathrm{L})$ & 30 & 0.010 & 0.020 & $<0.010$ & $<0.010$ & $<0.010$ & $<0.010$ & $<0.010$ & 0.123 & 2 \\
\hline Vanadium $(\mu \mathrm{g} / \mathrm{L})$ & 30 & 0.08 & 0.16 & 0.08 & 9.3 & 14.2 & 14.0 & 17.4 & 29.3 & $\uparrow 44$ \\
\hline $\operatorname{Zinc}(\mu \mathrm{g} / \mathrm{L})$ & 30 & 1.4 & 2.8 & $<1.4$ & 3.6 & 14 & 5.1 & 19.2 & 68.3 & $* 5,000$ \\
\hline Antimony $(\mu \mathrm{g} / \mathrm{L})$ & 30 & 0.027 & 0.054 & $<0.027$ & $* * 0.027$ & $* * 0.046$ & $* * 0.042$ & $* * 0.067$ & 0.099 & 6 \\
\hline Arsenic $(\mu \mathrm{g} / \mathrm{L})$ & 30 & 0.04 & 0.08 & 0.10 & 1.5 & 2.5 & 2.0 & 3.5 & 6.9 & 10 \\
\hline Boron $(\mu \mathrm{g} / \mathrm{L})$ & 30 & 3 & 6 & 32 & 92 & 154 & 128 & 147 & 781 & $\uparrow 4,900$ \\
\hline Selenium $(\mu \mathrm{g} / \mathrm{L})$ & 30 & 0.03 & 0.06 & $<0.03$ & 1.2 & 2.6 & 2.6 & 3.7 & 5.8 & 50 \\
\hline Uranium $(\mu \mathrm{g} / \mathrm{L})$ & 30 & 0.004 & 0.008 & 0.071 & 4.00 & 7.03 & 6.90 & 8.87 & 19.7 & 30 \\
\hline
\end{tabular}

0.004

0.008

0.071

4.00

data (Helsel and Hirsch, 2002).

${ }^{2}$ The 75th percentile, also called the upper quartile, is a value which exceeds no more than 75 percent of the data and is exceeded by no more than 25 percent of the data (Helsel and Hirsch, 2002).

${ }^{3}$ Maximum contaminant level, regulatory drinking-water standard set by the U.S. Environmental Protection Agency for public water supplies (U.S. Environmental Protection Agency, 2013).

‡Secondary drinking-water standard, non-regulatory drinking-water standard set by the U.S. Environmental Protection Agency for water supplies for pH and aluminum, which is listed as an acceptable range

(U.S. Environmental Protection Agency, 2013).

*Secondary drinking-water standard, non-regulatory drinking-water standard set by the U.S. Environmental Protection Agency for water supplies (U.S. Environmental Protection Agency, 2013).

**Value is estimated by using a log-probability regression to predict values below detection limit (Helsel, 2005).

$\dagger$ Value is recommended Texas Risk Reduction Program (TRRP) protective concentration level (pcl) for residential groundwater (Texas Commission on Environmental Quality, 2012). 
constituents by altering the oxidation and reduction reactions in groundwater. Becker and others (2002) measured a few wells in their study with dissolved-oxygen concentrations less than $2 \mathrm{mg} / \mathrm{L}$.

In the samples from most wells, $\mathrm{pH}$ values typically ranged from 7.3 to 7.8 with a median value of 7.6. Exceptions were the $\mathrm{pH}$ values of 8.4 and 8.7 measured in wells Da-3588 and Da-3589 in Dallam County, respectively (app. 1). The $8.7 \mathrm{pH}$ value exceeds the upper limit of 8.5 used as the MCL for $\mathrm{pH}$ by the EPA; $\mathrm{pH}$ values of 6.5 to 8.5 meet the secondary drinking-water standard for $\mathrm{pH}$ established by the EPA (U.S. Environmental Protection Agency, 2013).

Specific conductance ranged from 379 microsiemens per centimeter at 25 degrees Celsius $\left(\mu \mathrm{S} / \mathrm{cm}\right.$ at $\left.25^{\circ} \mathrm{C}\right)$ at well Oc-1291 to $1,230 \mu \mathrm{S} / \mathrm{cm}$ at $25^{\circ} \mathrm{C}$ at well Oc-4465 (both in Ochiltree County), with the largest dissolved-solids concentration also measured in well Oc-4465 (741 mg/L). The relation between specific conductance and dissolved solids was investigated by linear regression analysis; such a relation might be useful for estimating dissolved-solids concentrations where specific conductance is measured continuously, but dissolved-solids concentrations are only measured periodically (Helsel and Hirsch, 2002). The resulting linear regression equation is used for this estimate:

$$
D S=17.1+(0.601 \times S C)
$$

where
$D S$
is dissolved-solids concentration, in milligrams per liter; and
$S C$ is specific conductance, in microsiemens per centimeter at 25 degrees Celsius.

The linear regression between specific conductance and dissolved-solids concentration yielded a coefficient of determination or $R^{2}$ value (Helsel and Hirsch, 2002) of 0.98 (fig. 2), indicating a strong relation between specific conductance and dissolved solids.

The EPA (U.S. Environmental Protection Agency, 2013) has published National Secondary Drinking Water Regulations (secondary drinking-water standards) for many contaminants. The EPA describes secondary drinking-water standards as "non-enforceable guidelines regulating contaminants that cause cosmetic effects (such as skin or tooth discoloration) or aesthetic effects (such as taste, odor, or color) in drinking water***" (U.S. Environmental Protection Agency, 2013).

There were five wells where the dissolved-solids concentration exceeded the secondary drinking-water standard of $500 \mathrm{mg} / \mathrm{L}$. Three of the five wells with dissolved-solids concentrations greater than $500 \mathrm{mg} / \mathrm{L}$ were near the north-central part of the NPGCD in Ochiltree County (741 and $515 \mathrm{mg} / \mathrm{L}$, measured in samples from wells Oc-4465 and Oc-4196, respectively) or in Hansford County $(510 \mathrm{mg} / \mathrm{L}$, measured in the sample from well Hn-3686). A dissolved-solids concentration greater than $500 \mathrm{mg} / \mathrm{L}$ was also measured in the sample collected from a well in Dallam County $(569 \mathrm{mg} / \mathrm{L}$, measured in the sample from well Da-3589) (fig. 3, app. 1).
Water temperature can affect chemical reactions and biological processes in groundwater including those for $\mathrm{pH}$ and dissolved oxygen (Hem, 1985; Bruce and others 2003). The median water temperature was 18.0 degrees Celsius $\left({ }^{\circ} \mathrm{C}\right)$ (table 6). The water temperature was $17.8^{\circ} \mathrm{C}$ at Dallam County well Da-3588, where the $\mathrm{pH}$ was 8.4 and dissolved oxygen was $1.2 \mathrm{mg} / \mathrm{L}$. At Dallam County well Da-3589, the water temperature was $16.8^{\circ} \mathrm{C}$, the $\mathrm{pH}$ was 8.7 , and the dissolved oxygen was $0.1 \mathrm{mg} / \mathrm{L}$. The dissolved-oxygen concentrations measured in the groundwater obtained from these two wells were the lowest and the $\mathrm{pH}$ values were the highest among all the samples collected for this study.

Turbidity is an indirect measurement of the amount of suspended particulate matter in water. Turbidity values were consistently less than 3.0 nephelometric turbidity ratio units (NTRUs) indicating there were low concentrations of suspended particles; this finding is typical for groundwater analyses (Hem, 1985).

Alkalinity of a solution is the capacity for the solutes it contains to neutralize an acid (Hem, 1985) and is expressed in milligrams per liter as calcium carbonate (app. 1). Alkalinity has been used to describe the hardness of water with a range of 121 to $180 \mathrm{mg} / \mathrm{L}$ considered hard and alkalinity greater than $180 \mathrm{mg} / \mathrm{L}$ considered very hard (Hem, 1985). Most alkalinity concentrations ( 80 percent) were greater than $180 \mathrm{mg} / \mathrm{L}$ (fig. 4); the two highest values measured in the study area were measured in samples collected in Dallam County, where alkalinity values of $302 \mathrm{mg} / \mathrm{L}$ (well Da-3589) and 299 mg/L (well Da-3588) were measured. The next highest alkalinity value $(238 \mathrm{mg} / \mathrm{L})$ was measured in the sample collected from well Hn-1917 in Hansford County (app. 1). Of the 20 percent of the samples collected from wells with alkalinities less than $180 \mathrm{mg} / \mathrm{L}$, five wells were considered to contain hard water (157-176 mg/L), and an alkalinity value of $110 \mathrm{mg} / \mathrm{L}$ (moderately hard) was measured in the sample collected from one well in Hutchinson County, well Hu-4855. The median alkalinity reported by the Bruce and others (2003) was $193 \mathrm{mg} / \mathrm{L}$, whereas Becker and others (2002) reported a median alkalinity of $180 \mathrm{mg} / \mathrm{L}$. The median alkalinity for the 30 wells sampled in this study was $195 \mathrm{mg} / \mathrm{L}$ (table 6).

Boxplots depict the distribution of alkalinity, calcium, magnesium, potassium, sodium, bromide, chloride, fluoride, silica, and sulfate concentrations for each of the 30 wells characterized during this study (fig. 4). For the two major ions and dissolved solids with secondary drinking-water standards (dissolved solids, chloride, or sulfate; table 6), only the standard for dissolved solids was exceeded in a few samples.

Trilinear (Piper) diagrams (Piper, 1944) indicate most of the groundwater samples were similar in their major-ion chemical characteristics (fig. 5). Samples collected from 6 wells, 2 in Dallam County, 2 in Ochiltree County, and 1 each in Hutchinson and Hansford Counties, do not plot in the same general area of the Piper diagram as the remaining 24 samples, reflecting differences in chemical characteristics. On an overall basis, the dominant anions were carbonate and bicarbonate and chloride (fig. 5). The dominant cations 


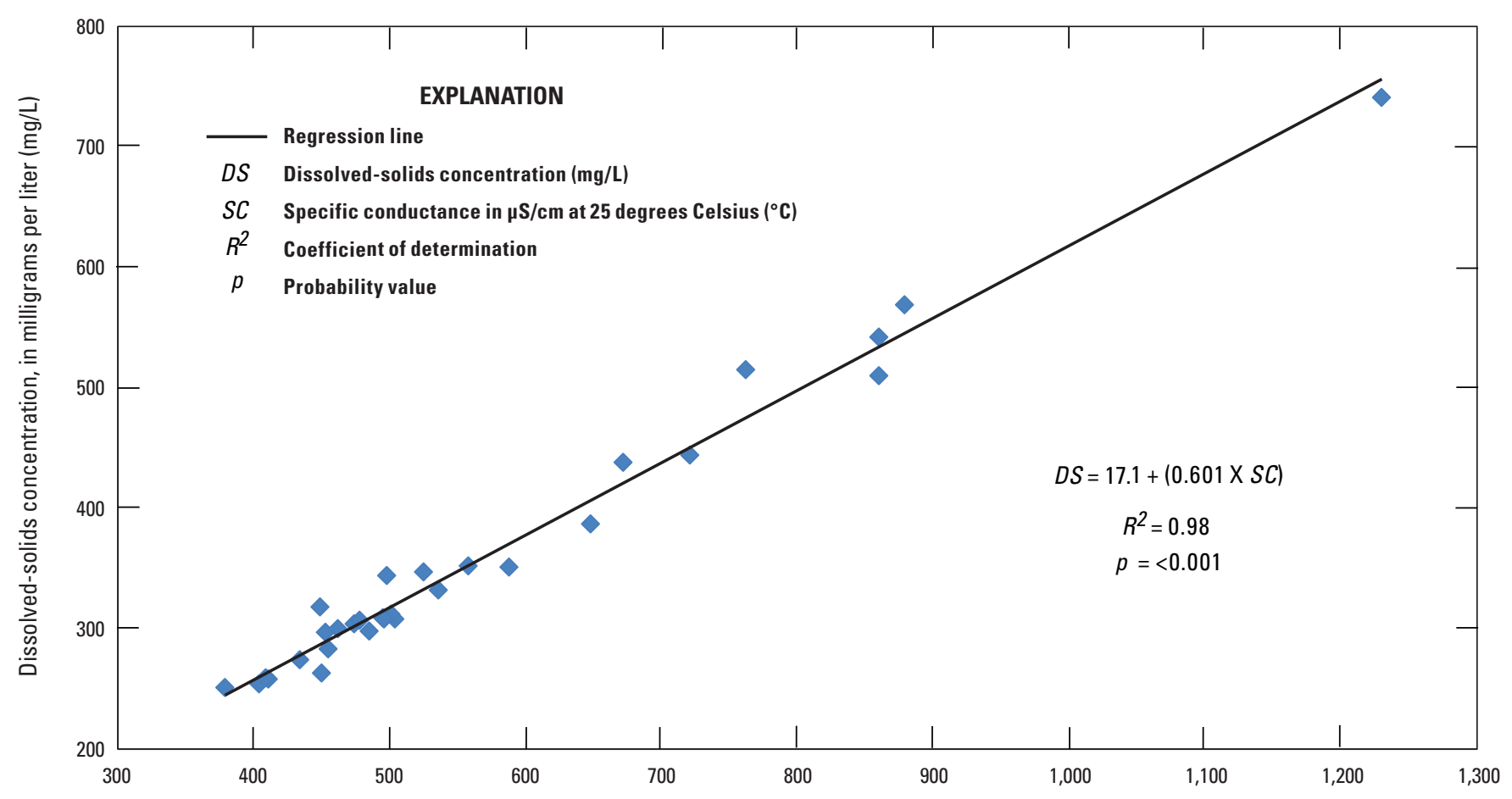

Specific conductance, in microsiemens per centimeter $(\mu \mathrm{S} / \mathrm{cm})$ at 25 degrees Celsius $\left({ }^{\circ} \mathrm{C}\right)$

Figure 2. Relation between dissolved-solids concentration and specific conductance measured in filtered and unfiltered samples, respectively, collected from 30 monitor wells in the North Plains Groundwater Conservation District management area in the Texas Panhandle, 2012-13.

were calcium, magnesium, and sodium, and the water type is generally a mixed cation-bicarbonate plus carbonate (fig. 5). Calcium concentrations ranged from 2.72 to $92.5 \mathrm{mg} / \mathrm{L}$ (table 6 , app. 1); the interquartile range (25th to 75 th percentile) representing the central 50 percent of the data (Helsel and Hirsch, 2002) was 35.7 to $50.0 \mathrm{mg} / \mathrm{L}$. Major sources of calcium include dissolution of carbonate minerals such as calcite, dolomite, and gypsum (Becker and others, 2002). Compared to the concentrations measured in samples collected from the other wells, which ranged from 26.5 to $92.5 \mathrm{mg} / \mathrm{L}$, two appreciably lower calcium concentrations were measured in the environmental samples collected from two wells in Dallum County, Da-3589 (2.72 mg/L) and Da-3588 $(5.04 \mathrm{mg} / \mathrm{L})$. Hem (1985) states that groundwater that has exchanged calcium for sodium is a common phenomenon, and the sodium concentrations for Da-3589 (203 mg/L) and Da-3588 (149 mg/L) were higher than the 75th percentile $(44.9 \mathrm{mg} / \mathrm{L})$ for sodium values in the study area. The low calcium concentrations of 2.72 and $5.04 \mathrm{mg} / \mathrm{L}$ were small enough that they might have been affected slightly by the small amount of bias and variability introduced from field processing and sampling equipment; calcium was detected in field blanks at concentrations of 0.077 and $0.090 \mathrm{mg} / \mathrm{L}$ and in an equipment blank $(0.12 \mathrm{mg} / \mathrm{L})$ (table 3$)$. The remaining 28 calcium concentrations measured in environmental samples were sufficiently large such that any bias and variability introduced from field processing and sampling equipment had a negligible effect. The low concentrations of magnesium $(0.016 \mathrm{mg} / \mathrm{L}$ or less) detected in two field blanks indicate that field processing and equipment had negligible effects on the reported concentrations of magnesium measured in the environmental samples.

Sodium concentrations ranged from 7.12 to $203 \mathrm{mg} / \mathrm{L}$ (fig. 4, table 6). Sodium plus potassium concentrations measured in samples collected from wells Da-3589 and Da-3588 in Dallum County and from well Oc-4465 in Ochiltree County plot in the far right section of the cation triangle on figure 5 , indicating that water from these three wells may be different compared to the water from other wells in the study area. The maximum sulfate concentration of $138 \mathrm{mg} / \mathrm{L}$ also was measured at the Da-3589 well (table 6). Excessive concentrations of sodium can be harmful to plants when used for irrigation (Becker and others, 2002). Clark and Mason (2006, p. 2) describe the effects of sodium on soil and describe the sodium-adsorption ratio (SAR) used to assess the sodium hazard for irrigation waters: 


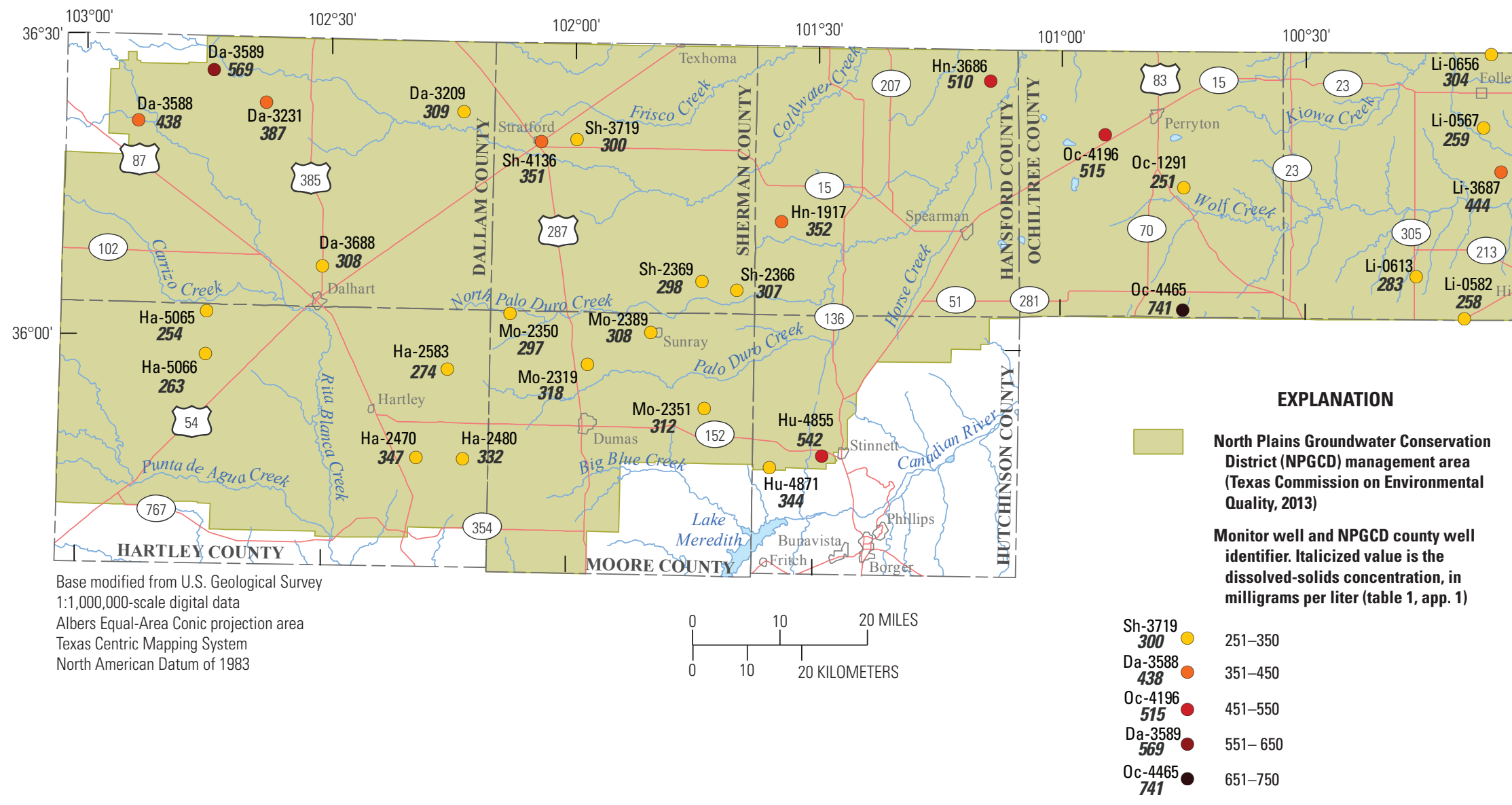

Figure 3. Dissolved-solids concentrations measured in filtered samples collected from 30 monitor wells in the North Plains Groundwater Conservation District management area, Texas Panhandle, 2012-13. 


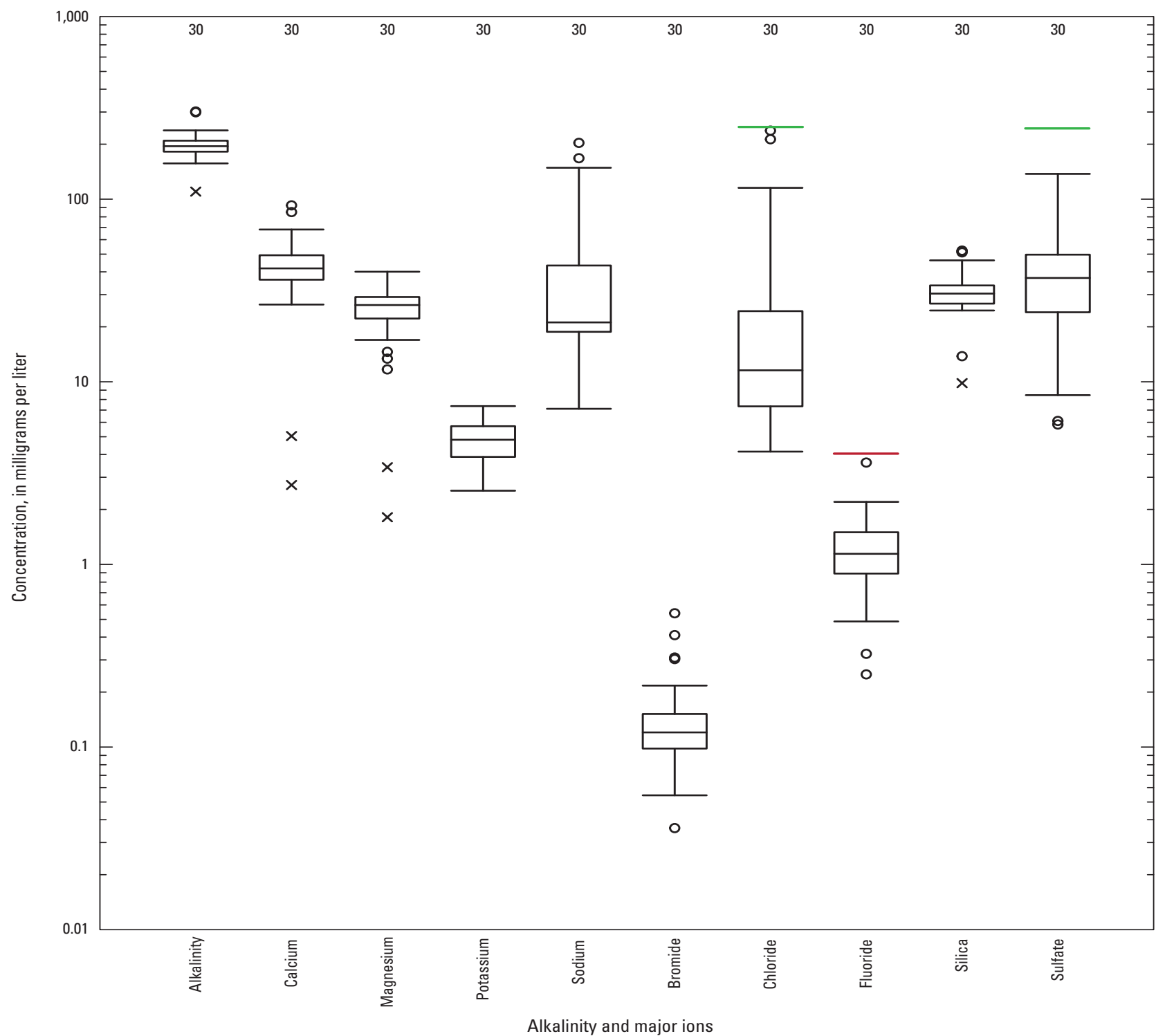

EXPLANATION

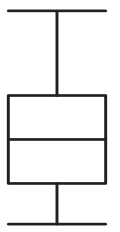

argest value within 1.5 times interquartile range above 75th percentile

5 th percentile

50th percentile (median)

IQR

25th percentile

mallest value within 1.5 times interquartile range below 25th percentile

IQR Interquartile range

- Outside value-Value is more than and less than 3 time the from either end of the box

$\times \quad$ Far-out value - Value is 3 times or more the IQR from either end of the box

Maximum contaminant level (U.S. Environmental Protection Agency, 2013)

Secondary drinking-water standard U.S. Environmental Protection Agency, 2013)

Figure 4. Distribution of alkalinity and major-ion concentrations measured in filtered samples collected from 30 monitor wells in the North Plains Groundwater Conservation District management area in the Texas Panhandle, 2012-13. 


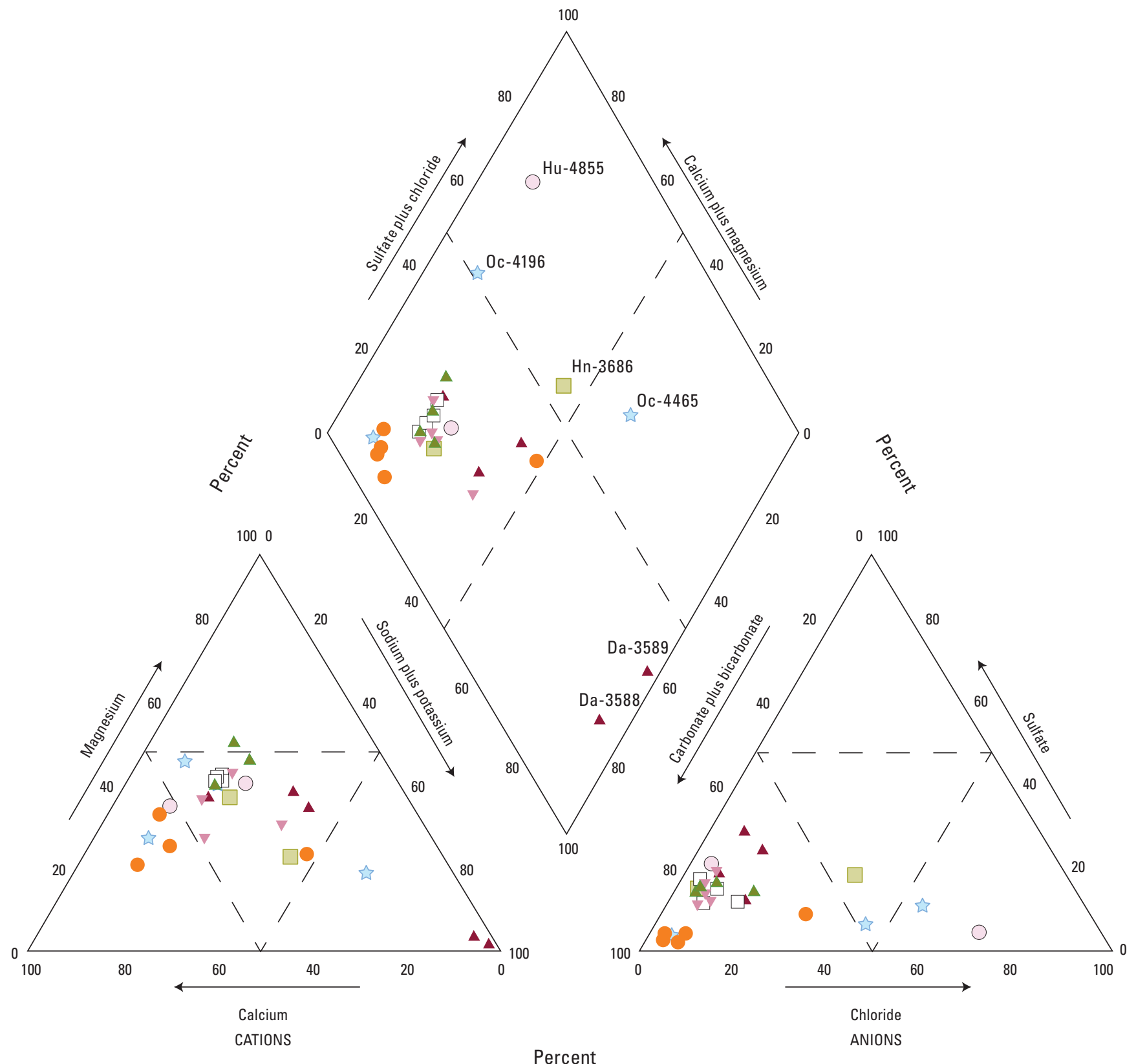

\section{EXPLANATION}

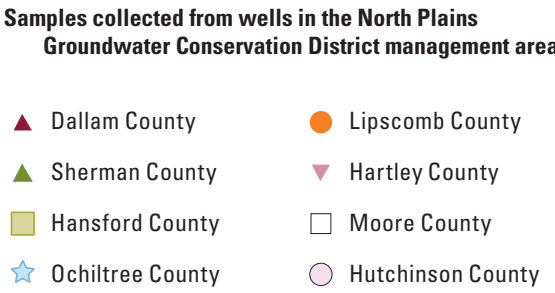

Figure 5. Chemical composition of constituents measured in filtered samples collected from 30 monitor wells in the North Plains Groundwater Conservation District, Texas Panhandle, 2012-13. 
***large concentrations of sodium can have a negative effect on soils by causing dispersion and swelling. Soil dispersion can harden the soil and decrease infiltration rates at the surface and reduce the hydraulic conductivity of the soil (Hanson and others, 1993). The ratio of sodium ions to calcium and magnesium ions can be used to predict the degree to which irrigation water tends to enter into the cation-exchange reactions in soil (U.S. Salinity Laboratory Staff, 1954). This ratio, called the sodium-adsorption ratio (SAR), is used to determine the sodium hazard for irrigation waters. As the SAR increases, the sodium hazard increases; therefore, the suitability of water for irrigation decreases.

The SAR value was calculated from the analytical results of calcium, magnesium, and sodium determined from each discrete sample by using the following equation:

$$
S A R=\frac{N a^{+}}{\sqrt{\frac{C a^{2+}+M g^{2+}}{2}}}
$$

where

$\begin{array}{ll}\mathrm{SAR} & \text { is the sodium-adsorption ratio, } \\ & \text { dimensionless; and } \\ & \text { represent concentrations of sodium, } \\ & \text { calcium, and magnesium ions } \\ & \text { expressed in milliequivalents per } \\ & \text { liter. }\end{array}$

SAR values ranging from 0 to 10,10 to 18 , and 18 to 26 , represent low, medium, and high sodium hazards, respectively (U.S. Salinity Laboratory Staff, 1954). The sample collected at Da-3589 had a SAR of 23.4, and the SAR for the sample collected from well Da-3588 was 12.5. The SARs measured in all other samples were less than 10 .

Chloride concentrations ranged from 4.15 to $237 \mathrm{mg} / \mathrm{L}$; the 25 th to 75 th percentile range representing central 50 percent of the data (Helsel and Hirsch, 2002) was 7.33 to $26.0 \mathrm{mg} / \mathrm{L}$ (table 6). Chloride concentrations of 237 and 213 $\mathrm{mg} / \mathrm{L}$ were measured in the samples collected from wells Oc-4465 in Ochiltree County and Hu-4855 in Hutchinson County, respectively. The chloride values for these two wells plot the farthest right of all samples in the anion triangle of the Piper diagram (fig. 5). Becker and others (2002) describe the possible sources of chloride as including dissolution of chloride-bearing minerals, seepage of brackish waters from underlying aquifers, contamination by brines from oil and gas production, or contamination by sewage or animal wastes. The EPA secondary drinking-water standard for chloride is 250 mg/L (table 6; U.S. Environmental Protection Agency, 2013).

Sulfate concentrations represented only a small part of the dissolved-solid concentrations. The median sulfate concentration was $37.1 \mathrm{mg} / \mathrm{L}$ (fig. 4, table 6). Bruce and others
(2003) reported that the sulfate concentrations in several samples in their study exceeded the 250-mg/L EPA secondary drinking-water standard. Becker and others (2002) also reported sulfate concentrations in a few samples that exceeded $250 \mathrm{mg} / \mathrm{L}$. In this study, there was one sulfate concentration of $138 \mathrm{mg} / \mathrm{L}$ measured in the sample collected from well Da-3589 that was appreciably larger than the rest of the sulfate concentrations (the next largest concentration was $80.2 \mathrm{mg} / \mathrm{L}$ ), but it was still much smaller than the EPA secondary drinkingwater standard of $250 \mathrm{mg} / \mathrm{L}$.

\section{Nutrients}

A nutrient is an element or compound essential for animal or plant growth. Common nutrients in fertilizer include nitrogen, phosphorus, and potassium (U.S. Geological Survey, 2007; Mueller and Helsel, 1996). Water quality of an aquifer can be adversely affected if nutrient-laden recharge water originating from the land surface percolates through the substrate to water-bearing layers of the aquifer. Water with nitrate concentrations of more than $10 \mathrm{mg} / \mathrm{L}$ can cause methemoglobinemia (also known as blue-baby syndrome) in infants less than 6 months of age and is considered a major contaminant and threat to groundwater quality in Texas (Chaudhuri and others, 2012). Mueller and Helsel (1996) state that nitrate can be produced by the natural decomposition of organic material in the soil and, under oxygenated conditions, is likely to be present in most natural waters with a national average background-nitrate concentration for water unaffected by human sources of less than $2.0 \mathrm{mg} / \mathrm{L}$. Becker and others (2002) measured a median nitrate concentration of $2.04 \mathrm{mg} / \mathrm{L}$ for wells not thought to have been affected by recent recharge.

Samples were collected for the determination of 4 species of nitrogen (ammonia, nitrite plus nitrate, nitrite, and total nitrogen) and 1 species of phosphorus (orthophosphate). Ammonia concentrations were less than or equal to the LT-MDL of $0.010 \mathrm{mg} / \mathrm{L}$ for 28 of the 30 wells that were sampled (app. 1). The wells with ammonia concentrations greater than $0.010 \mathrm{mg} / \mathrm{L}$ were Da-3588 $(0.105 \mathrm{mg} / \mathrm{L}$ measured on March 3, 2012) and Da-3589 $(0.163 \mathrm{mg} / \mathrm{L}$ also measured on March 3, 2012). These two ammonia concentrations might reflect a slight positive bias given that an ammonia concentration of $0.012 \mathrm{mg} / \mathrm{L}$ was measured in the field blank collected March 4, 2012, 1 day after the environmental samples were collected. The threshold concentration to identify bias in the field blank was $0.024 \mathrm{mg} / \mathrm{L}$; that concentration would have resulted in the environmental sample results being rejected; table 4). There were no detections of ammonia in any of the subsequent field blanks, equipment blanks, or rinse-water blanks.

Nitrite concentrations (app. 1) were less than the LRL $(0.001 \mathrm{mg} / \mathrm{L})$ except for a detection of $0.001 \mathrm{mg} / \mathrm{L}$ at the Dallam County well Da-3209. The nitrate species dominate the concentration determined in the nitrite plus nitrate analysis. Because mostly no nitrate was detected, results for 
the nitrite plus nitrate analysis are hereinafter referred to as "nitrate concentrations." The median nitrate concentration for the study was $2.05 \mathrm{mg} / \mathrm{L}$ (table 6), which is the same as the national nitrate median concentration determined by Mueller and Helsel (1996). However, nitrate concentrations at two wells, Sh-4136 in Sherman County $(11.6 \mathrm{mg} / \mathrm{L})$ and Da-3688 in Dallam County $(10.5 \mathrm{mg} / \mathrm{L})$, exceeded the $10-\mathrm{mg} / \mathrm{L} \mathrm{MCL}$ set by the EPA (U.S. Environmental Protection Agency, 2013) for drinking-water supplies. Water from these two wells did not have large dissolved-solids concentrations. Three of the four wells with nitrate concentrations in the 3.01 to $5.00 \mathrm{mg} / \mathrm{L}$ range are in Ochiltree or Lipscomb County (fig. 6). Total nitrogen concentrations were similar to the nitrate concentrations indicating that nitrate concentrations compose most of the nitrogen concentrations. Total nitrogen is defined as nitrite plus nitrate plus ammonia plus organic nitrogen.

Phosphorus is important in agricultural systems for development of high-yielding crops, especially corn, soybeans, and wheat (Domagalski and Johnson, 2012). A total of 4,247,000 tons of phosphorus fertilizer was applied to crops in the United States in 2008, an increase of 25 percent when compared to the total applied in 1964 (Domagalski and Johnson, 2012). Long-term over-application of manure and chemical fertilizers that contain phosphorus can result with phosphorus movement into the groundwater system resulting in potential contamination of the groundwater resource (Domagalski and Johnson, 2012). Because the median orthophosphate concentration was only $0.014 \mathrm{mg} / \mathrm{L}$ for the 30 wells that were sampled (table 6), it is unlikely phosphorus contamination of groundwater from agricultural practices is currently (2014) present in the study area.

\section{Trace Elements}

Environmental samples from each well were analyzed to determine the concentrations of 23 trace elements (table 6). Trace elements are substances that typically are present in concentrations of less than $1.0 \mathrm{mg} / \mathrm{L}$ (Hem, 1985). A total of 10 trace elements (aluminum, beryllium, cadmium, chromium, cobalt, copper, iron, silver, thallium, and antimony) generally were not detected at concentrations greater than or equal to the applicable LRLs. Median concentrations for these 10 trace elements were determined by using a logarithmic-probability regression (Helsel, 2005) to predict values less than the LRL. The summary statistics for the 10 trace elements that were rarely detected at concentrations equal to or greater than the LRL are documented in table 6, and the results of individual analyses are shown in appendix 1 . The remaining 13 trace elements (barium, lead, lithium, manganese, molybdenum, nickel, strontium, vanadium, zinc, arsenic, boron, selenium, and uranium) generally were detected at concentrations greater than or equal to the applicable LRLs.

Barium can affect human health by stimulating the smooth, striated, and cardiac muscles, which elevates blood pressure and initiates the release catecholamines, such as epinephrine (adrenaline) (Kojola and others, 1979). Health effects from barium are most likely when concentrations in public or private drinking-water supplies exceed the MCL standard of 2,000 $\mu \mathrm{g} / \mathrm{L}$ set by the EPA (U.S. Environmental Protection Agency, 2013). Barium concentrations ranged from $11.0 \mu \mathrm{g} / \mathrm{L}$ at well Da-3589 in Dallam County to $526 \mu \mathrm{g} / \mathrm{L}$ at well Li-0613 in Lipscomb County; the median concentration was $83.8 \mu \mathrm{g} / \mathrm{L}$ (fig. 7, table 6), which is much less than the $2,000 \mu \mathrm{g} / \mathrm{L}$ MCL. Low concentrations of barium, detected in the field-blank samples and the equipment blank, are considered of negligible effect on barium concentrations analyzed in the environmental samples (tables 3 and 4).

Lead is rarely present in source water (U.S.

Environmental Protection Agency, 2013), but lead in drinking water can cause a variety of adverse health effects. In babies and children, exposure to lead in drinking water greater than the MCL of $15 \mu \mathrm{g} / \mathrm{L}$ can result in delays in physical and mental development, along with slight deficits in attention span and learning abilities. Adults who drink water containing more than $15 \mu \mathrm{g} / \mathrm{L}$ of lead over many years could develop kidney problems or high blood pressure (U.S. Environmental Protection Agency, 2013). A supplier of drinking water must take corrective actions and inform the public when the MCL is exceeded (U.S. Environmental Protection Agency, 2013). Lead was detected in low concentrations ranging from a minimum of $0.208 \mu \mathrm{g} / \mathrm{L}$ to a maximum of $0.868 \mu \mathrm{g} / \mathrm{L}$ (fig. 7, table 6). Whereas the low lead concentrations detected do not warrant concerns about lead in water withdrawn from the Ogallala Formation of the central High Plains aquifer in the study area, most lead enters drinking water through plumbing materials (U.S. Environmental Protection Agency, 2013).

Lithium is an alkali metal that has a wide array of uses from batteries to ceramics, lubricating greases, pyrotechnics, and pharmaceuticals (Baldessarini and others, 2006). Lithium concentrations ranged from a minimum of $20.8 \mu \mathrm{g} / \mathrm{L}$ measured in the sample from well Li-0582 in Lipscomb County to a maximum $105 \mu \mathrm{g} / \mathrm{L}$ in the sample from well Da-3231 in Dallam County, with a median concentration of $45.0 \mu \mathrm{g} / \mathrm{L}$ (fig. 7, table 6). The TRRP protective concentration level for lithium in residential groundwater is $49 \mu \mathrm{g} / \mathrm{L}$ (Texas Commission on Environmental Quality, 2012). The EPA has not established an MCL or secondary drinking-water standard for lithium (U.S. Environmental Protection Agency, 2013).

Manganese is naturally occurring, and its solubility in water is governed by oxidation and reduction processes that generally are similar to those for iron (Hem, 1985). Although an essential nutrient at low doses, chronic exposure to high doses may cause neurological damage (U.S. Environmental Protection Agency, 2004). The maximum manganese concentration of $26.5 \mu \mathrm{g} / \mathrm{L}$ was detected in the sample from well Sh-4136 in Sherman County (table 6). Manganese concentrations ranged from 0.15 to $0.54 \mu \mathrm{g} / \mathrm{L}$ in the blank samples with the exception of the rinse-blank sample that was collected March 6, 2013. Given the manganese detections in blank samples, environmental concentrations of less than 1.08 


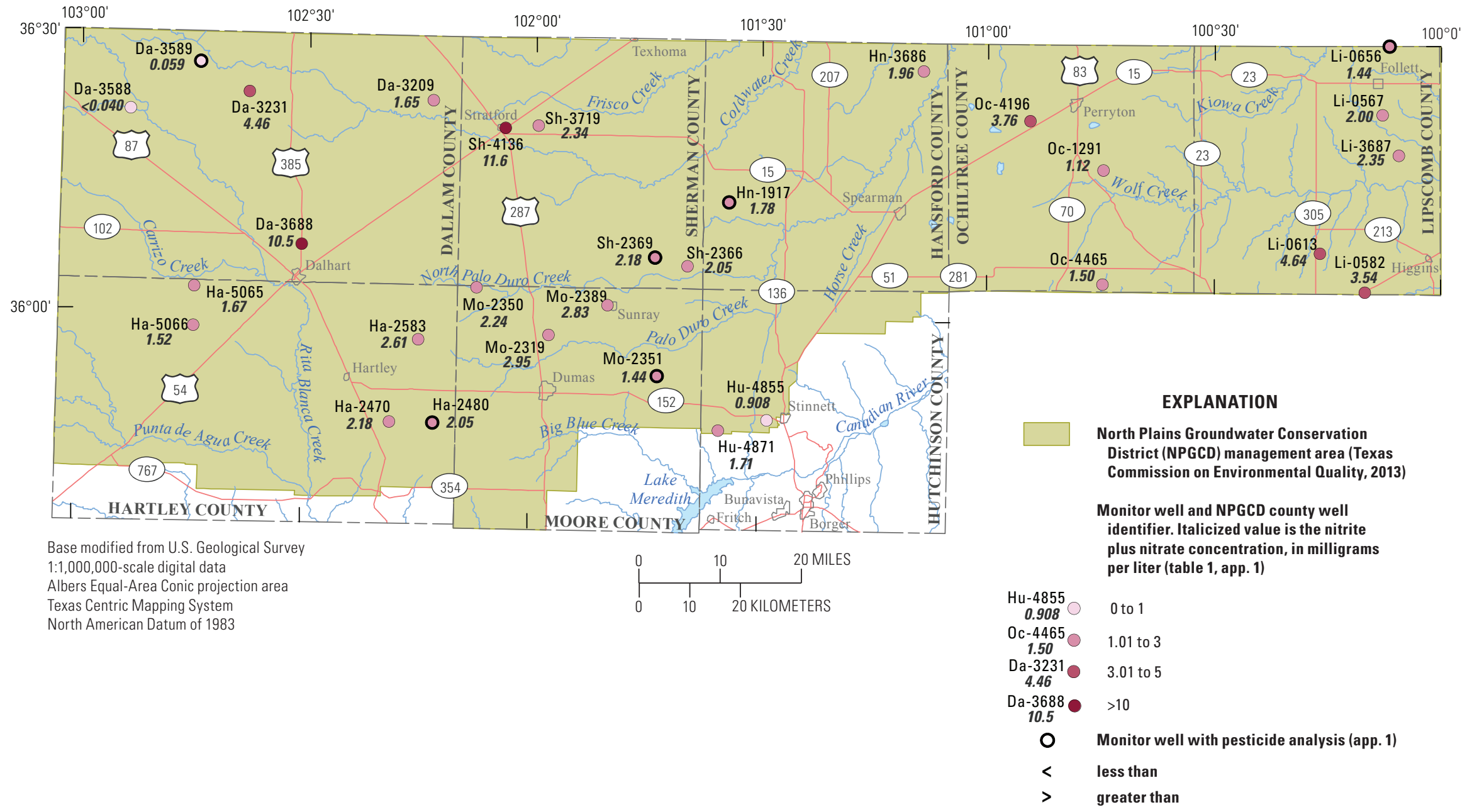

Figure 6. Nitrate concentrations (nitrite plus nitrate) measured in filtered samples collected from 30 monitor wells and locations of selected wells where samples were collected for pesticide analyses, North Plains Groundwater Conservation District, Texas Panhandle, 2012-13. 


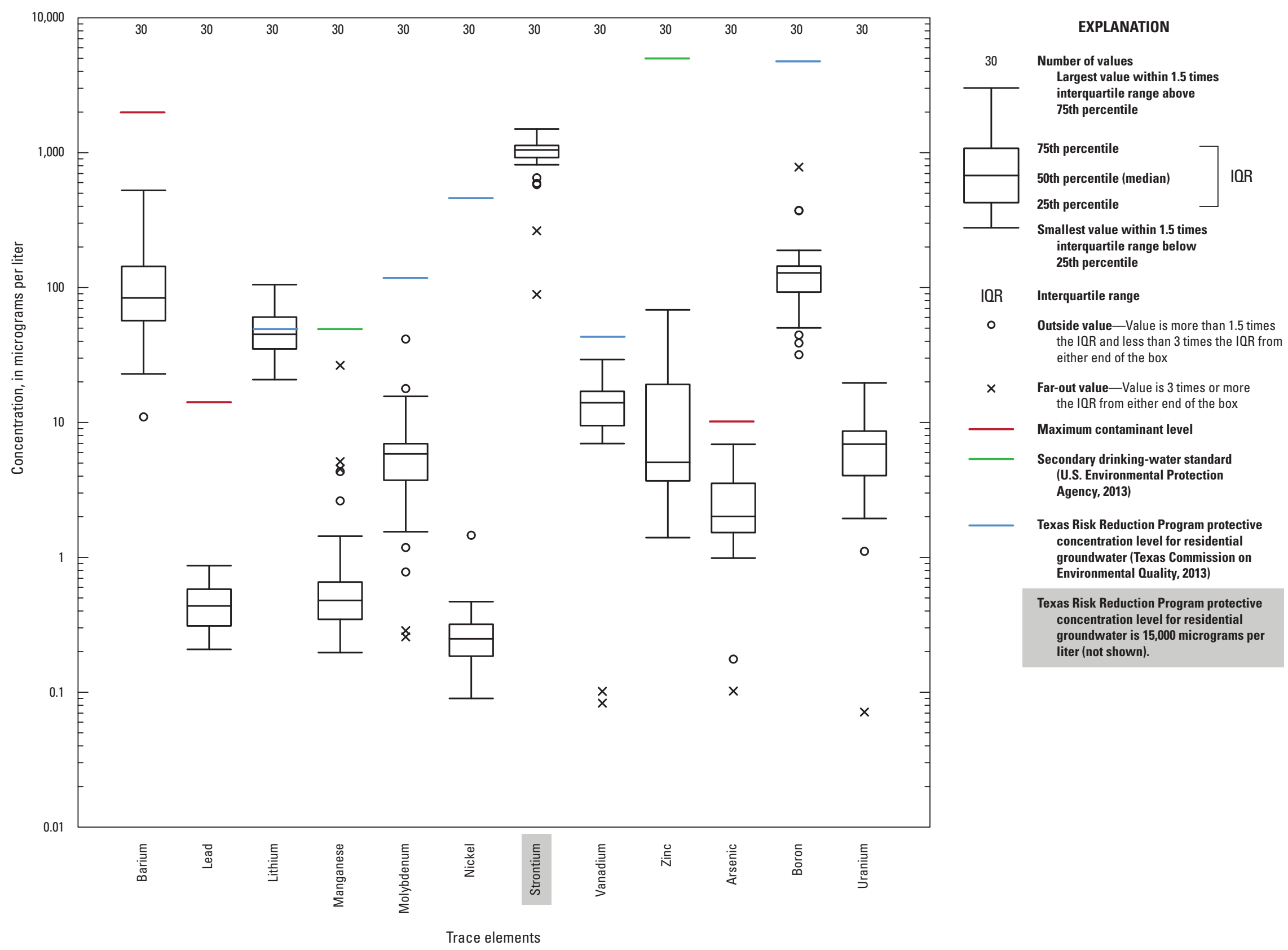

Figure 7. Trace-element concentrations measured in filtered samples collected from 30 monitor wells in the North Plains Groundwater Conservation District, Texas Panhandle, 2012-13. 
$\mu \mathrm{g} / \mathrm{L}$ could be biased high (tables 3 and 4 ). The second highest manganese concentrations were detected in 3 of the 5 Dallam County wells and ranged from 4.32 to $5.13 \mu \mathrm{g} / \mathrm{L}$. The secondary drinking-water standard of $0.05 \mathrm{mg} / \mathrm{L}(50 \mu \mathrm{g} / \mathrm{L})$ for manganese (U.S. Environmental Protection Agency, 2013) was not exceeded.

Molybdenum is a metallic element that is naturally present, usually at low concentrations, in the earth's crust (Hem, 1985). The World Health Organization (2011a) considers molybdenum to be an essential element for human health with an estimated daily requirement of $0.1-0.3 \mathrm{mg}$ for adults. The results from a cross-sectional study of 400 people in two settlements of a molybdenum-rich province of the former Soviet Union suggested that the high incidence (18-31 percent) of a gout-like disease was associated with high intake of molybdenum (10-15 mg/day) (World Health Organization, 2011b). Naturally occurring levels of molybdenum in groundwater are low; the USGS found a median value of 2.5 $\mu \mathrm{g} / \mathrm{L}$ in 1,159 samples collected nationwide with 25 percent of the samples having concentrations that were $0.95 \mu \mathrm{g} / \mathrm{L}$ or less and 75 percent of the concentrations $5.9 \mu \mathrm{g} / \mathrm{L}$ or less (Ayotte and others, 2011).

Molybdenum is associated with dissolution of molybdenite and is highly soluble under oxidizing conditions (Becker and others, 2002). The median value of molybdenum was $5.86 \mu \mathrm{g} / \mathrm{L}$, which was larger than the 50th percentile value of $2.5 \mu \mathrm{g} / \mathrm{L}$ that Ayotte and others (2011) denoted. The sample collected from Dallam County well Da-3589 had the maximum concentration of molybdenum at $41.5 \mu \mathrm{g} / \mathrm{L}$ (table 6). Molybdenum concentrations ranged from 0.257 to $17.8 \mu \mathrm{g} / \mathrm{L}$ in the other 29 samples collected in the study area (fig. 7, app. 1). The TRRP protective concentration level for molybdenum in residential groundwater of $120 \mu \mathrm{g} / \mathrm{L}$ (Texas Commission on Environmental Quality, 2012) is much larger than the highest concentration measured in the study area. The EPA has not established an MCL or secondary drinking-water standard for molybdenum (U.S. Environmental Protection Agency, 2013).

Nickel is a metal that occurs naturally in soils, groundwater, and surface water; it is often used in electroplating, stainless steel and alloy products, mining, and refining (U.S. Geological Survey, 2014c). According the EPA, chronic long-term exposure to nickel at concentrations above the MCL of $0.1 \mathrm{mg} / \mathrm{L}(100 \mu \mathrm{g} / \mathrm{L})$ has the potential to cause decreased body weight, heart and liver damage, and dermatitis (U.S. Environmental Protection Agency, 2013). Nickel was detected in 29 of the 30 wells that were sampled, and the nickel concentrations were slightly greater than the LRL of $0.18 \mu \mathrm{g} / \mathrm{L}$. The maximum concentration of nickel $(1.5 \mu \mathrm{g} / \mathrm{L})$ was detected in the sample collected from well Sh-4136 in Sherman County. The median concentration of nickel was 0.25 $\mu \mathrm{g} / \mathrm{L}$. The TRRP protective concentration level for nickel in residential groundwater is $490 \mu \mathrm{g} / \mathrm{L}$ (Texas Commission on Environmental Quality, 2012).

Strontium concentrations were detected in the samples collected from all 30 wells, with a median concentration of $1,040 \mu \mathrm{g} / \mathrm{L}$ and a 25 th to 75 th percentile range of 915 to $1,140 \mu \mathrm{g} / \mathrm{L}$ (fig. 7, table 6). The maximum strontium concentration $1,500 \mu \mathrm{g} / \mathrm{L}$ was detected in the sample collected from well Sh-4136 in Sherman County (table 6). The median concentration for strontium of $1,040 \mu \mathrm{g} / \mathrm{L}$ is much higher than the national median strontium concentration of $110 \mu \mathrm{g} / \mathrm{L}$ reported by Hem (1985) for public-water supplies. There is no EPA established MCL for strontium; the TRRP protective concentration level for strontium in residential groundwater is $15,000 \mu \mathrm{g} / \mathrm{L}$.

Vanadium is a naturally occurring and widely distributed element in the earth's crust; natural releases to water and soil are far greater overall than human-made releases to the atmosphere associated with the burning of fossil fuels (Agency for Toxic Substances and Disease Registry, 2012). Vanadium concentrations were detected in all of the 30 wells sampled with a median concentration of $14.0 \mu \mathrm{g} / \mathrm{L}$ and a $25 \mathrm{th}$ to 75 th percentile range of 9.3 to $17.4 \mu \mathrm{g} / \mathrm{L}$ (fig. 7, table 6). The maximum concentration of vanadium $(29.3 \mu \mathrm{g} / \mathrm{L})$ was detected in the sample collected at well Li-3687 in Lipscomb County (table 6). Low concentrations of vanadium (0.08 and $0.09 \mu \mathrm{g} / \mathrm{L}$ ) were detected in two of the blank samples that were collected (tables 3 and 4), indicating that sample collection and processing did not introduce appreciable bias to environmental samples with the exceptions of the environmental samples collected from wells Da-3588 and Da-3589. Wells Da-3588 and Da-3589 had concentrations of 0.10 and $0.08 \mu \mathrm{g} / \mathrm{L}$ respectively - concentrations which were about the same as those measured in the two blank samples. The concentrations of vanadium in all other environmental samples were much larger than the concentrations measured in the blank samples. The EPA has not set an MCL for vanadium; the TRRP protective concentration level for vanadium in residential groundwater is $44 \mu \mathrm{g} / \mathrm{L}$.

Zinc was detected in 29 of the 30 wells sampled (the sample collected from Dallam County well Da-3589 was the only one with a zinc concentration less than the LT-MDL of $1.4 \mu \mathrm{g} / \mathrm{L}$ ). Zinc is a common, naturally occurring metal. Becker and others (2002, p. 24-25) note "zinc occurs in crustal rocks in similar abundance as copper and nickel, but is substantially more soluble in natural waters than those metals. Zinc also is a component of brass and bronze and is used to galvanize steel pipes and sheets. Galvanized metals associated with plumbing or well casing may augment concentrations of zinc in water from wells constructed of such materials." Researchers have documented copper deficiencies in various mammals as a result of excessive zinc consumption (Elinder, 1986; Torrance and Fulton, 1986), and a highzinc diet has been determined to induce hypocalcaemia and bone resorption in rats (Yamaguchi and others, 1983). The maximum concentration of zinc $(68.3 \mu \mathrm{g} / \mathrm{L})$ was detected in the sample collected from the Dallam County well Da-3588 and the concentration was much lower than the secondary drinking-water standard established by the EPA of $5 \mathrm{mg} / \mathrm{L}$ $(5,000 \mu \mathrm{g} / \mathrm{L})$ (U.S. Environmental Protection Agency, 2013). Zinc concentrations ranging from 1.8 to $2.4 \mu \mathrm{g} / \mathrm{L}$ were 
detected in 3 of 5 blank samples, indicating that the detected concentrations of zinc of less than $4.8 \mu \mathrm{g} / \mathrm{L}$ measured in environmental samples might contain varying amounts of zinc contamination (table 4, app. 1).

Arsenic is a semimetallic element. Citing the work of others, Welch and others $(2000$, p. 1) note "arsenic is a naturally occurring element in rocks, soils, and the waters in contact with them. Recognized as a toxic element for centuries, arsenic today also is a human-health concern because it can contribute to skin, bladder, and other cancers (National Research Council, 1999)." Arsenic is odorless and tasteless and enters drinking-water supplies from natural deposits in the earth or from agricultural and industrial practices (U.S. Environmental Protection Agency, 2013). Arsenic has an MCL of $10 \mu \mathrm{g} / \mathrm{L}$ set to protect consumers served by public-water systems from the effects of long-term, chronic exposure to arsenic (U.S. Environmental Protection Agency, 2013). The two highest arsenic concentrations were detected in samples collected from wells in the eastern part of the study area at well Li-3687 $(6.9 \mu \mathrm{g} / \mathrm{L})$ in Lipscomb County and well Oc-1291 (5.5 $\mu \mathrm{g} / \mathrm{L})$ in Ochiltree County (fig. 8). Arsenic concentrations between the 25 th percentile of $1.5 \mu \mathrm{g} / \mathrm{L}$ to the 75th percentile of $3.5 \mu \mathrm{g} / \mathrm{L}$ (fig. 8, table 6) do not exceed drinking-water standards. Wells with measured arsenic values in the 2.0 to $5.0 \mu \mathrm{g} / \mathrm{L}$ range were found in each county except for Moore County (fig. 8).

Boron is a nonmetallic element found in rocks, soil, and water, always in combination with oxygen, such as boric acid, or as borate salts because the element, boron, does not exist naturally (Moore and others, 1997). Present in the human body in trace amounts, the question of whether boron is an essential nutrient remains in debate (University of Michigan Health System, 2014). Boron adversely affects reproductive and developmental health in larger amounts (Fail and others, 1998). Whereas the EPA has not established an MCL or secondary drinking-water standard for boron in drinking water (U.S. Environmental Protection Agency, 2013), the World Health Organization established a guideline value of $2.4 \mathrm{mg} / \mathrm{L}$ $(2,400 \mu \mathrm{g} / \mathrm{L})$ for the safe consumption of elemental boron in drinking water (World Health Organization, 2011a), and the TRRP protective concentration level for boron in residential groundwater is $4.9 \mathrm{mg} / \mathrm{L}(4,900 \mu \mathrm{g} / \mathrm{L})$ (Texas Commission on Environmental Quality, 2012). For the 30 wells sampled, the interquartile range was 92 to $147 \mu \mathrm{g} / \mathrm{L}$, with a median boron concentration of $128 \mu \mathrm{g} / \mathrm{L}$. The maximum boron concentration $(781 \mu \mathrm{g} / \mathrm{L})$ was measured in the sampled collected from Dallam County well Da-3589 (table 6).

Uranium is a naturally occurring metal found at low levels in almost all rock, soil, and water samples. Appreciable concentrations of uranium occur in some substances such as phosphate rock deposits and minerals such as uraninite in uranium-rich ores (U.S. Environmental Protection Agency, 2012b). Phosphate fertilizers can contain uranium, and when they are applied to crops, some of the uranium might migrate to the groundwater (Stanton and Qi, 2006). Exposure to uranium in drinking water might cause kidney damage, and prolonged exposure at concentrations exceeding the MCL for drinking water $(30 \mu \mathrm{g} / \mathrm{L})$ is likely to increase the risk of cancer (U.S. Environmental Protection Agency, 2009). Uranium concentrations were low in all wells ranging from 0.071 to $19.7 \mu \mathrm{g} / \mathrm{L}$. The maximum concentration of uranium $(19.7 \mu \mathrm{g} / \mathrm{L})$ was detected in the sample collected at the Dallam County well Da-3231 (table 6).

\section{Pesticides}

As explained in the introduction of this report, pesticide compounds (and their degradates) include pesticides and herbicides applied to control (kill) undesirable insects and vegetation, respectively. In the study area, pesticides are applied primarily on cropland to enhance crop production or around homes and livestock to control pests and weeds. Pesticides can migrate to groundwater as the original compound or as degradate products formed as the original compounds break down into other compounds in the environment (Stanton and Qi, 2006). The detection of pesticides and their degradate products in groundwater is a concern for those using groundwater as a drinking-water supply (Becker and others, 2002). The effects of chronic exposure to pesticides can cause a range of human-health problems, such as liver and kidney damage to cancer and reproductive failure (U.S. Environmental Protection Agency, 2009). Many factors affect the fate and transport of pesticides from when they are applied on the land surface to when they ultimately reach the water table. Some of the factors affecting the possible migration of pesticide from the land surface to the groundwater in the Ogallala Formation include improper well-head construction; amount of pumping in the area; characteristics and composition of the vadose zone and the saturated zone including porosity, hydraulic conductivity, hydraulic gradient, and layers; oxidation and reduction (redox) conditions; organic matter (U.S. Environmental Protection Agency, 1993); and the chemical properties of the pesticide including transformation products and reaction pathways (Barbesh and Resek, 1996). For this study, six water-quality samples were collected in 2012 and analyzed for 116 pesticides or degradate compounds of pesticides (table 7).

The LT-MDLs and LRLs for the pesticides analyzed for in this study are listed in table 7 . The following wells were sampled for pesticides: well Mo-2351 in Moore County, well Sh-2369 in Sherman County, well Hn-1917 in Hansford County, well Da-3589 in Dallam County, well Ha-2480 in Hartley County, and well Li-0656 Lipscomb County. Of the 6 pesticide samples collected, 2 had pesticide detections for atrazine and CIAT, an atrazine degradate (table 8). Atrazine is a triazine herbicide commonly used to control broadleaf and grassy weeds in a variety of crops such as corn and sorghum and has an MCL of $3.0 \mu \mathrm{g} / \mathrm{L}$ (U.S. Environmental Protection Agency, 2013). Atrazine has been one of the most heavily used herbicides in the United States for decades and is marketed as a stand-alone product or as a mixture with other herbicides, fertilizers, or both. Along with its degradation 


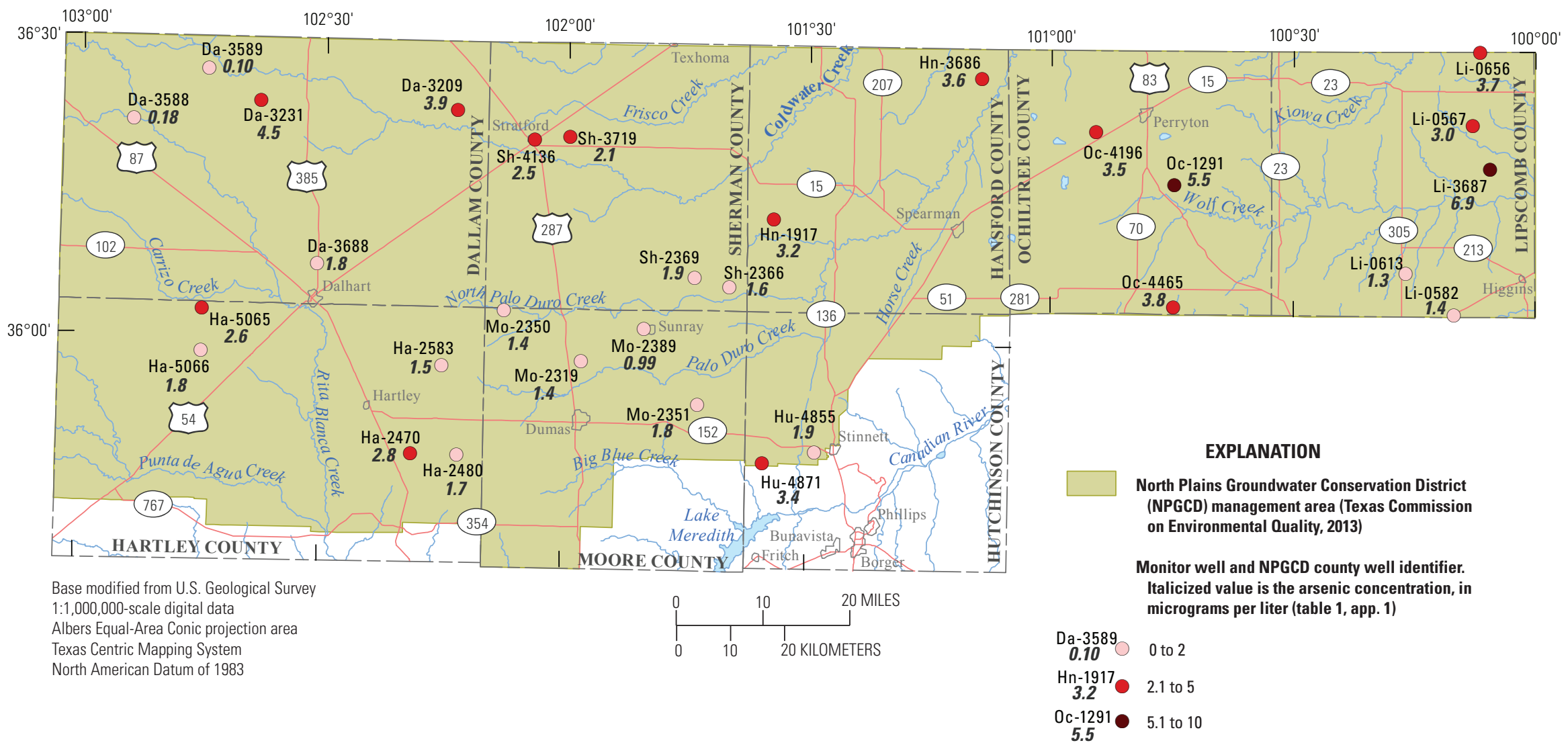

Figure 8. Arsenic concentrations measured in filtered samples collected from 30 monitor wells in the North Plains Groundwater Conservation District, Texas Panhandle, 2012-13. 
Table 7. Pesticides and associated degradate compounds analyzed in water-quality samples collected from six monitor wells in the North Plains Groundwater Conservation District, Texas Panhandle, 2012.

[NWQL, National Water Quality Laboratory; USGS, U.S. Geological Survey; SC, analytical schedule code; OGRL, U.S. Geological Survey Organic Chemistry Research Laboratory; CIAT, 2-Chloro-4-isopropylamino-6-amino-s-triazine; DCPA, Dacthal; EPTC, S-Ethyl dipropylthiocarbamate; LCPD, liquid chromatography/acetamide parents and degradation products; LCGY, liquid chromatography/Glyphosate, Aminomethylphosphonic Acid (AMPA), and Glufosinate]

\begin{tabular}{|c|c|c|c|c|c|}
\hline Pesticide & $\begin{array}{c}\text { NWOL long- } \\
\text { term method } \\
\text { detection level } \\
\text { for the study } \\
\text { period } \\
\text { (LT-MDL) }\end{array}$ & $\begin{array}{c}\text { NWOL } \\
\text { laboratory } \\
\text { reporting level } \\
\text { for the study } \\
\text { period } \\
\text { (LRL) }\end{array}$ & Pesticide & $\begin{array}{c}\text { NWOL long- } \\
\text { term method } \\
\text { detection level } \\
\text { for the study } \\
\text { period } \\
\text { (LT-MDL) }\end{array}$ & $\begin{array}{c}\text { NWQL } \\
\text { laboratory } \\
\text { reporting level } \\
\text { for the study } \\
\text { period } \\
\text { (LRL) }\end{array}$ \\
\hline \multicolumn{6}{|c|}{ Pesticides, USGS SC2033, in micrograms per liter $(\mu \mathrm{g} / \mathrm{L})$} \\
\hline 1-Naphthol & 0.018 & 0.0360 & Fenamiphos & 0.015 & 0.030 \\
\hline 2-Chloro-2',6'-diethylacetanilide & 0.005 & 0.010 & Fipronil sulfone & 0.012 & 0.024 \\
\hline CIAT & 0.003 & 0.006 & Fipronil & 0.009 & 0.018 \\
\hline 2-Ethyl-6-methylaniline & 0.005 & 0.010 & Fonofos & 0.0024 & 0.0048 \\
\hline 3,4-Dichloroaniline & 0.003 & 0.0060 & Hexazinone & 0.006 & 0.012 \\
\hline 3,5-Dichloroaniline & 0.003 & 0.006 & Iprodione & 0.007 & 0.014 \\
\hline Atrazine & 0.004 & 0.008 & Metalaxyl & 0.007 & 0.014 \\
\hline Azinphos-methyl oxygen analog & 0.021 & 0.042 & Methidathion & 0.006 & 0.012 \\
\hline Azinphos-methyl & 0.060 & 0.120 & Methyl paraoxon & 0.007 & 0.014 \\
\hline Benfluralin & 0.007 & 0.014 & Methyl parathion & 0.004 & 0.008 \\
\hline Carbaryl & 0.030 & 0.060 & Metolachlor & 0.010 & 0.020 \\
\hline Carbofuran & 0.030 & 0.060 & Metribuzin & 0.006 & 0.012 \\
\hline Chlorpyrifos oxygen analog & 0.04 & 0.08 & Molinate & 0.0020 & 0.0040 \\
\hline Chlorpyrifos & 0.0018 & 0.0036 & Myclobutanil & 0.005 & 0.010 \\
\hline cis-Permethrin & 0.005 & 0.010 & Oxyfluorfen & 0.005 & 0.010 \\
\hline cis-Propiconazole & 0.004 & 0.008 & Pendimethalin & 0.006 & 0.012 \\
\hline Diazinon & 0.0030 & 0.0060 & Propanil & 0.005 & 0.010 \\
\hline Dichlorvos & 0.02 & 0.04 & Propargite & 0.010 & 0.020 \\
\hline Dicrotophos & 0.04 & 0.08 & Propyzamide & 0.0018 & 0.0036 \\
\hline Dieldrin & 0.004 & 0.008 & Simazine & 0.003 & 0.006 \\
\hline Dimethoate & 0.005 & 0.010 & Tebuthiuron & 0.014 & 0.028 \\
\hline Disulfoton sulfone & 0.007 & 0.014 & Tefluthrin & 0.007 & 0.014 \\
\hline Disulfoton & 0.020 & 0.040 & Terbufos oxygen analog sulfone & 0.022 & 0.045 \\
\hline Endosulfan sulfate & 0.008 & 0.016 & Terbufos & 0.009 & 0.018 \\
\hline ЕРТC & 0.0028 & 0.0056 & Terbuthylazine & 0.004 & 0.008 \\
\hline Ethion monoxon & 0.011 & 0.021 & Thiobencarb & 0.008 & 0.016 \\
\hline Ethion & 0.005 & 0.010 & trans-Propiconazole & 0.009 & 0.018 \\
\hline Ethoprophos & 0.008 & 0.016 & Tribuphos & 0.009 & 0.018 \\
\hline Fenamiphos sulfone & 0.027 & 0.054 & Trifluralin & 0.009 & 0.018 \\
\hline Fenamiphos sulfoxide & 0.04 & 0.08 & & & \\
\hline
\end{tabular}


Table 7. Pesticides and associated degradate compounds analyzed in water-quality samples collected from six monitor wells in the North Plains Groundwater Conservation District, Texas Panhandle, 2012.—Continued

[NWQL, National Water Quality Laboratory; USGS, U.S. Geological Survey; SC, analytical schedule code; OGRL, U.S. Geological Survey Organic Chemistry Research Laboratory; CIAT, 2-Chloro-4-isopropylamino-6-amino-s-triazine; DCPA, Dacthal; EPTC, S-Ethyl dipropylthiocarbamate; LCPD, liquid chromatography/acetamide parents and degradation products; LCGY, liquid chromatography/Glyphosate, Aminomethylphosphonic Acid (AMPA), and Glufosinate]

\begin{tabular}{|c|c|c|c|c|c|}
\hline Pesticide & \multicolumn{2}{|c|}{ OGRL laboratory reporting level' } & Pesticide & \multicolumn{2}{|c|}{ OGRL laboratory reporting level' } \\
\hline \multicolumn{6}{|c|}{ Pesticides and associated degradate compound, USGS SC LCGY, in micrograms per liter $(\mu \mathrm{g} / \mathrm{L})$} \\
\hline Glyphosate & 0.02 & 0.02 & $\begin{array}{l}\text { Aminomethylphosphonic } \\
\text { Acid (AMPA)* }\end{array}$ & 0.02 & 0.02 \\
\hline Glufosinate & 0.02 & 0.02 & & & \\
\hline \multicolumn{6}{|c|}{ Pesticide and associated degradate compounds, USGS SC LCPD, in micrograms per liter ( $\mu \mathrm{g} / \mathrm{L})$} \\
\hline Acetochlor oxanilic acid* & 0.02 & 0.02 & Flufenacet sulfonic acid* & 0.02 & 0.02 \\
\hline Acetochlor sulfonic acid* & 0.02 & 0.02 & Flufenacet & 0.02 & 0.02 \\
\hline Acetochlor sulfinylacetic acid* & 0.02 & 0.02 & Hydroxy-alachlor* & 0.02 & 0.02 \\
\hline Acetochlor & 0.02 & 0.02 & Hydroxy-acetochlor* & 0.02 & 0.02 \\
\hline Alachlor & 0.02 & 0.02 & Metolachlor sulfonic acid* & 0.02 & 0.02 \\
\hline Dechloroacetochlor* & 0.02 & 0.02 & Metolachlor & 0.02 & 0.02 \\
\hline Dechloroalachlor* & 0.02 & 0.02 & Propachlor oxanilic acid* & 0.02 & 0.02 \\
\hline Dechlorodimethenamid & 0.02 & 0.02 & Propachlor sulfonic acid* & 0.05 & 0.05 \\
\hline Dechlorometolachlor* & 0.02 & 0.02 & Propachlor & 0.02 & 0.02 \\
\hline Dimethenamid oxanilic acid* & 0.02 & 0.02 & sec-Alachlor sulfonic acid* & 0.02 & 0.02 \\
\hline Dimethenamid sulfonic acid* & 0.02 & 0.02 & $\begin{array}{l}\text { 2-Chloro-2',6'- } \\
\text { diethylacetanilide* }\end{array}$ & 0.02 & 0.02 \\
\hline Dimethenamid & 0.02 & 0.02 & $\begin{array}{l}\text { 2-Chloro-N-(2-ethyl-6-meth- } \\
\text { ylphenyl)acetamide* }\end{array}$ & 0.02 & 0.02 \\
\hline
\end{tabular}

${ }^{1}$ OGRL uses one reporting level that is equal to or greater than the limit of quantitation (Michael Meyer, OGRL, oral commun., 2014).

*Pesticide degradate compound. 
Table 8. Concentrations of detected pesticides and 95-percent confidence intervals for the recovery of these detected pesticides measured in water-quality samples collected from six monitor wells in the North Plains Groundwater Conservation District, Texas Panhandle, 2012.

[NPGCD, North Plains Groundwater Conservation District; NWQL, National Water Quality Laboratory; $\mu \mathrm{g} / \mathrm{L}$, micrograms per liter; CIAT, 2-Chloro-4isopropylamino-6-amino-s-triazine; E, estimated]

\begin{tabular}{|c|c|c|c|c|c|}
\hline Pesticide & $\begin{array}{c}\text { NPGCD county } \\
\text { well identifier } \\
\text { and map identifier } \\
\text { (fig. 1) }\end{array}$ & $\begin{array}{l}\text { NWOL long-term } \\
\text { method detection } \\
\text { level (LT-MDL) } \\
\text { for the study period } \\
(\mu \mathrm{g} / \mathrm{L})\end{array}$ & $\begin{array}{c}\text { NWQL laboratory } \\
\text { reporting level (LRL) } \\
\text { for the study period } \\
(\mu \mathrm{g} / \mathrm{L})\end{array}$ & $\begin{array}{c}\text { Measured } \\
\text { concentration } \\
(\mu \mathrm{g} / \mathrm{L})\end{array}$ & $\begin{array}{l}\text { NWOL 95-percent } \\
\text { confidence interval } \\
\text { for recovery,' in } \\
\text { percent, in pesticide- } \\
\text { grade blank water }\end{array}$ \\
\hline CIAT & Sh-2369 & 0.003 & 0.006 & E0.018 & 16 to 106 \\
\hline CIAT & Hn-1917 & 0.003 & 0.006 & E0.023 & 16 to 106 \\
\hline Atrazine & Sh-2369 & 0.004 & 0.008 & 0.013 & 70 to 113 \\
\hline Atrazine & Hn-1917 & 0.004 & 0.008 & 0.008 & 70 to 113 \\
\hline Tebuthiuron & На- 2480 & 0.014 & 0.028 & E0.016 & 9 to 240 \\
\hline
\end{tabular}

${ }^{1}$ Recovery is the measured amount of pesticide in the spiked quality control sample expressed as a percentage of the amount spiked.

products, atrazine commonly is detected in surface water and groundwater (International Agency for Research on Cancer, 1999; Thelin and others, 2010; U.S. Environmental Protection Agency, 2012a). Detected atrazine concentrations were slightly greater than or equal to the LRL of $0.008 \mu \mathrm{g} / \mathrm{L}$, and detected CIAT concentrations also were slightly greater than the LRL of $0.006 \mu \mathrm{g} / \mathrm{L}$. Well Sh-2369 in Sherman County had a detected atrazine concentration of $0.013 \mu \mathrm{g} / \mathrm{L}$ and an estimated CIAT concentration of $0.018 \mu \mathrm{g} / \mathrm{L}$. Well Hn-1917 in Hansford County had a detected atrazine concentration of $0.008 \mu \mathrm{g} / \mathrm{L}$ and an estimated CIAT concentration of $0.023 \mu \mathrm{g} / \mathrm{L}$. The 95 -percent confidence interval for CIAT recovery is 16 to 106 percent using pesticide-grade blank water spiked with this constituent (table 8). The CIAT values determined during this study were estimated values that were greater than the LT-MDL and less than the LRL. The herbicide tebuthiuron was detected in the sample collected from one well. Tebuthiuron primarily is used to control broadleaf and woody weeds, including grasses and brush on rangeland and pastures; it also is commonly used along railroads and at industrial facilities (U.S. Environmental Protection Agency, 1994). A small amount $(0.016 \mu \mathrm{g} / \mathrm{L})$ of tebuthiuron was detected in a sample collected from a well in Hartley County (Ha-2480) (table 8). The tebuthiuron detection exceeded the LT-MDL of $0.014 \mu \mathrm{g} / \mathrm{L}$ but was less than the LRL of $0.028 \mu \mathrm{g} / \mathrm{L}$ (table 8). Because the upper limits of the 95-percent confidence intervals for CIAT and tebuthiuron recovery in spiked samples were more than 100 percent (table 5), it is possible that although tebuthiuron and CIAT were sometimes detected in environmental samples at concentrations greater than or equal to the LT-MDL (a positive bias), the actual concentrations in the environmental samples might have been smaller that the LT-MDL.

There were no detections for glyphosate, AMPA, and glufosinate in the wells sampled, although the use of these herbicides is growing rapidly in the United States (Scribner and others, 2007). There also were no detections for some of the common pesticides used for agricultural purposes, such as herbicides (metolachlor, cyanazine, alachlor, and acetochlor) and insecticides (diazinon, carbofuran, carbaryl, and malathion). Nitrate concentrations of less than $2.2 \mathrm{mg} / \mathrm{L}$ were measured in the six wells sampled for pesticides (fig. 6 ), indicating that groundwater in areas where these wells are located may not currently (2014) be affected by agricultural recharge (return flows from water not utilized by crop plants). Wells Da-3688 and Sh-4136 were not sampled for pesticides during this study but exceeded the MCL for nitrate of $10 \mathrm{mg} / \mathrm{L}$ and would be logical candidates for sampling for pesticides in future studies. Given that the sample size (30 total samples and 6 pesticide samples) was small and the data were collected during 2 years, the water-quality results of this study do not provide evidence of deteriorating water quality associated with the groundwater depletions in the study area. 


\section{Summary}

The High Plains aquifer is a vast, extensively used groundwater system underlying 111.8 million acres in parts of Colorado, Kansas, Nebraska, New Mexico, Oklahoma, South Dakota, Wyoming, and Texas. The Ogallala Formation is the primary water-bearing unit of the High Plains aquifer, including the central High Plains aquifer underlying the North Plains Groundwater Conservation District (NPGCD) in the Texas Panhandle. The study area coincides with the NPGCD management area, which includes the entire northern five counties that form the border between Texas and Oklahoma: Dallam, Sherman, Hansford, Ochiltree, and Lipscomb Counties and parts of the three counties south of the aforementioned counties, Hartley, Moore, and Hutchinson. The NPGCD covers a total of 7,324 square miles of which 25 percent was in agriculture production during 2012 and had 81,854 residents as of 2010. The U.S. Geological Survey (USGS) documented the results of a reconnaissance-level survey in cooperation with the NPGCD of the water quality in the Ogallala Formation within the NPGCD management area of the central High Plains aquifer in the Texas Panhandle.

The USGS measured depth to groundwater levels and collected water-quality samples at 30 monitor wells in the NPGCD management area. Each monitor well was completed in the Ogallala Formation of the central High Plains aquifer. The wells were measured and sampled once during FebruaryMarch 2012 and March 2013. The depth to groundwater was measured before sampling to help ensure the sampling hose intake was at a proper depth to provide a representative sample from the well. Six of the 30 wells were sampled in 2012 for commonly used pesticides and herbicides, focusing on those that had been detected in previous studies nationwide. The shallowest water level (76.60 feet [ft]) was measured in well Li-0613 in Lipscomb County, and the deepest water level (480.8 ft) was measured in well Ha-2583 in Hartley County. Sampling depths from land surface ranged from $120 \mathrm{ft}$, measured at well Li-0613, to $500 \mathrm{ft}$, measured at well Ha-2583. Groundwater-level elevations ranged from 2,279 ft at well Li-3687 in Lipscomb County to 4,160 ft at well Da-3588 in Dallam County.

Samples were collected from five wells where the dissolved-solids concentration exceeded the 500 milligrams per liter $(\mathrm{mg} / \mathrm{L})$ secondary drinking-water standard set by the U.S. Environmental Protection Agency (EPA) for drinking-water supply wells. A regression analysis of specific conductance and dissolved solids found specific conductance to be a good surrogate for dissolved solids with a coefficient of determination $\left(R^{2}\right)$ value of 0.98 . The sample collected from well Da-3589 had a sodium-adsorption ratio (SAR) (ratio of sodium ions to calcium and magnesium ions) of 23.4, and the SAR for the sample collected from well Da-3588 was 12.5; no other samples were collected with a SAR greater than 10 . Median nitrate concentrations for the study were $2.05 \mathrm{mg} / \mathrm{L}$, which is the same as the median nitrate concentration determined by previous investigators in a national study. Nitrate concentrations at two wells, Sh-4136 in Sherman County $(11.6 \mathrm{mg} / \mathrm{L})$ and Da-3688 in Dallam County (10.5 $\mathrm{mg} / \mathrm{L}$ ), exceeded the $10-\mathrm{mg} / \mathrm{L}$ maximum contaminant level (MCL) set by the EPA for drinking-water supplies. Samples from each well were analyzed to determine the concentrations of 23 trace elements. In the samples collected, 13 trace elements (barium, lead, lithium, manganese, molybdenum, nickel, strontium, vanadium, zinc, arsenic, boron, selenium, and uranium) generally were detected at concentrations greater than or equal to the applicable laboratory reporting levels (LRLs), whereas the remaining 10 trace elements generally were not detected at concentrations greater than or equal to the applicable LRLs. None of the 23 trace elements were measured at concentrations exceeding the secondary drinkingwater standard or MCL set by the U.S. Environmental Protection Agency for water supplies. Of the six pesticide samples collected, two wells, Hn-1917 in Hansford County and Sh-2369 in Sherman County, had pesticide detections for atrazine and its degradate, 2-Chloro-4-isopropylamino6-amino-s-triazine (CIAT). Detected atrazine concentrations were slightly greater than or equal to the LRL of 0.008 micrograms per liter $(\mu \mathrm{g} / \mathrm{L})$, and detected CIAT concentrations also were slightly greater than the laboratory reporting level of $0.006 \mu \mathrm{g} / \mathrm{L}$. The sample collected at well Ha-2480 in Hartley County had a detected tebuthiuron concentration of $0.016 \mu \mathrm{g} / \mathrm{L}$, which is above the long-term method detection level but below the LRL. Although the use of these herbicides is growing rapidly and glyphosate has become the most commonly used conventional pesticide in the United States agricultural market sector, there were no detections for glyphosate, its degradation product aminomethylphosphonic acid (AMPA), or glufosinate in the six wells sampled for pesticide compounds for this study. Given that the sample size was small (30 total samples and 6 pesticide samples) and the data were collected during 2 years, the water-quality results of this study do not provide evidence of deteriorating water quality associated with the groundwater depletions in the study area. The data from this study serve as a baseline for future water-quality monitoring in the study area.

\section{References Cited}

Agency for Toxic Substances and Disease Registry, 2012, Public health statement-Vanadium: U.S. Division of Toxicology and Human Health Sciences, Public Health Service, accessed September 21, 2014, at http://www.atsdr. cdc.gov/substances/toxsubstance. asp?toxid $=50$. 
American Public Health Association, 1998, Standard methods for the examination of water and wastewater (20th ed.): Washington, D.C., American Public Health Association, American Water Works Association, and Water Environment Federation, p. 3-37-3-43.

Ayotte, J.D., Gronberg, J.M., and Apodaca, L.E., 2011, Trace elements and radon in groundwater across the United States: U.S. Geological Survey Scientific Investigations Report 2011-5059, 115 p., accessed September 5, 2014, at http:// pubs.er.usgs.gov/publication/sir20115059.

Baldessarini, R.J., Tondo, Leonardo, Davis, Paula, Pompili, Maurizio, Goodwin, F.K., and Hennen, John, 2006, Decreased risk of suicides and attempts during longterm lithium treatment-A meta-analytic review: Bipolar Disorders, v. 8, no. 5, p. 625-639.

Barbash, J.E., and Resek, E.A., 1996, Pesticides in ground water-Distribution, trends, and governing factors, v. 2 of Pesticides in the hydrologic system: Chelsea, Mich., Ann Arbor Press, 590 p.

Bartolino, J.R., and Cunningham, W.L., 2003, Ground-water depletion across the Nation: U.S. Geological Survey Fact Sheet 103-03, 4 p., accessed September 5, 2014, at http:// pubs.er.usgs.gov/publication/fs 10303.

Battaglin, W.A., Meyer, M.T., Kuivila, K.M., and Dietze, J.E., 2014, Glyphosate and its degradation product AMPA occur frequently and widely in U.S. soils, surface water, groundwater, and precipitation: Journal of the American Water Resources Association (JAWRA), v. 50, no. 2, p. 275-290. [Available at 10.1111/jawr.12159.]

Beaumont, Peter, 1985, Irrigated agriculture and groundwater mining on the High Plains of Texas, USA: Environmental Conservation, v. 12, no. 2, p. 119-130, accessed June 10, 2014, at http://journals.cambridge.org/action/dis playAbstract?fromPage $=$ online\&aid $=5928464 \&$ fileI $\mathrm{d}=\mathrm{S} 0376892900015538$.

Becker, M.F., Bruce, B.W., Pope, L.M., and Andrews, W.J., 2002, Ground-water quality in the central High Plains aquifer, Colorado, Kansas, New Mexico, Oklahoma, and Texas, 1999: U.S. Geological Survey Water-Resources Investigations Report 02-4112, 64 p., accessed September 5, 2014, at http:// pubs.er.usgs.gov/publication/wri20024112.

Bruce, B.W., Becker, M.F., Pope, L.M., and Gurdak, J.J., 2003, Ground-water quality beneath irrigated agriculture in the central High Plains aquifer, 1999-2000: U.S. Geological Survey Water-Resources Investigations Report 2003-4219, 39 p., accessed September 5, 2014, at http://pubs.er.usgs.gov/ publication/wri034219.
Chaudhuri, Sriroop, Ale, Srinvasulu, DeLaune, Paul, and Rajan, Nithya, 2012, Spatio-temporal variability of groundwater nitrate concentration in Texas-1960 to 2010: Journal of Environmental Quality, v. 41, no. 6, p. 18061817.

Childress, C.J.O., Foreman, W.T., Connor, B.F., and Maloney, T.J., 1999, New reporting procedures based on long-term method detection levels and some considerations for interpretations of water-quality data provided by the U.S. Geological Survey National Water Quality Laboratory: U.S. Geological Survey Open-File Report 99-193, 19 p., accessed September 5, 2014, at http://pubs.er.usgs.gov/ publication/ofr99193.

Clark, M.L., and Mason, J.P., 2006, Water-quality characteristics, including sodium-adsorption ratios, for four sites in the Powder River drainage basin, Wyoming and Montana, water years 2001-2004: U.S. Geological Survey Scientific Investigations Report 2006-5113, 22 p., accessed September 5, 2014, at http://pubs.er.usgs.gov/publication/ sir20065113.

Cunningham, W.L., and Schalk, C.W., comps., 2011, Groundwater technical procedures of the U.S. Geological Survey: U.S. Geological Survey Techniques and Methods 1-A1, 151 p., accessed September 5, 2014, at http://pubs. er.usgs.gov/publication/tm1A1.

Domagalski, J.L., and Johnson, Henry, 2012, Phosphorus and groundwater-Establishing links between agricultural use and transport to streams: U.S. Geological Survey Fact Sheet 2012-3004, 4 p., accessed September 4, 2014, at http:// pubs.usgs.gov/fs/2012/3004/.

Dugan, J.T., Schild, D.E., and Kastner, W.M., 1990, Waterlevel changes in the High Plains aquifer underlying parts of South Dakota, Wyoming, Nebraska, Colorado, Kansas, New Mexico, Oklahoma, and Texas-Predevelopment through nonirrigation season 1988-89: U.S. Geological Survey Water-Resources Investigations Report 90-4153, 27 p., accessed July 15, 2014, at http://pubs.usgs.gov/ wri/1990/4153/report.pdf.

Elinder, C.G., 1986, Zinc, in Friberg, L., Nordberg, G.F., Vouk, V.B., eds., Handbook on the toxicology of metals (2d ed): Amsterdam, Elsevier Science Publishers, p. 664-679.

Fail, P.A., Chapin, R.E., Price, C.J., and Heindel, Jerrold, 1998, General, reproductive, developmental, and endocrine toxicity of boronated compounds: Reproductive Toxicology, v. 12 , no. 1, p. $1-18$. 
Fishman, M.J., ed., 1993, Methods of analysis by the U.S. Geological Survey National Water Quality LaboratoryDetermination of inorganic and organic constituents in water and fluvial sediments: U.S. Geological Survey OpenFile Report 93-125, p. 27-45, accessed September 5, 2014, at http://pubs.er.usgs.gov/publication/ofr93125.

Fishman, M.J., and Friedman, L.C., 1989, Methods for determination of inorganic substances in water and fluvial sediments: U.S. Geological Survey Techniques of WaterResources Investigations, book 5, chap. A1, 545 p., accessed September 5, 2014, at http://pubs.er.usgs.gov/ publication/twri05A1.

Garbarino, J.R., 1999, Methods of analysis by the U.S. Geological Survey National Water Quality LaboratoryDetermination of dissolved arsenic, boron, lithium, selenium, strontium, thallium, and vanadium using inductively coupled plasma-mass spectrometry: U.S. Geological Survey Open-File Report 99-093, 31 p., accessed September 5, 2014, at http://pubs.er.usgs.gov/ publication/ofr9993.

Garbarino, J.R., Kanagy, L.K., and Cree, M.E., 2006, Determination of elements in natural-water, biota, sediment and soil samples using collision/reaction cell inductively coupled plasma-mass spectrometry: U.S. Geological Survey Techniques and Methods, book 5, sec. B, chap.1, 88 p., accessed September 5, 2014, at http://pubs.er.usgs.gov/ publication/tm5B1.

Gilbert, S.G., 2013, A small dose of toxicology - The health effects of common household chemicals ( $2 \mathrm{~d}$ ed.): Seattle, Wash., Healthy World Press, 280 p., accessed June 10, 2014, at http://www.toxipedia.org/display/hwt/A+Small+Do $\mathrm{se}+\mathrm{of}+$ Toxicology $\% 2 \mathrm{C}+2 \mathrm{nd}+$ Edition.

Gutentag, E.D., Heimes, F.J., Krothe, N.C., Luckey, R.R., and Weeks, J.B., 1984, Geohydrology of the High Plains aquifer in parts of Colorado, Kansas, Nebraska, New Mexico, Oklahoma, South Dakota, Texas, and Wyoming: U.S. Geological Survey Professional Paper 1400-B, 63 p., accessed September 5, 2014, at http://pubs.er.usgs.gov/ publication/pp1400B.

Hanson, B.R., Grattan, S.R., and Fulton, A., 1993, Agricultural salinity and drainage: Davis, California, University of California Irrigation Program, Water Management Handbook Series, Publication 93-01, 141 p.

Helsel, D.R., 2005, Nondetects and data analysis, statistics for censored environmental data: Hoboken, New Jersey, John Wiley and Sons, Inc., 251 p.
Helsel, D.R., and Hirsch, R.M., 2002, Statistical methods in water resources: U.S. Geological Survey Techniques of Water Resources Investigations, book 4, chap. A3, 522 p., accessed June 3, 2014, at http://pubs.usgs.gov/twri/twri4a3/ pdf/twri4a3-new.pdf.

Hem, J.D., 1985, Study and interpretation of the chemical characteristics of natural water (3d ed): U.S. Geological Survey Water-Supply Paper 2254, 263 p., accessed September 5, 2014, at http://pubs.er.usgs.gov/publication/ wsp2254.

International Agency for Research on Cancer (IARC), 1999, Some chemicals that cause tumours of the kidney or urinary bladder in rodents and some other substances-Atrazine: IARC Monographs, v. 73, p. 59, accessed July 16, 2014, at http://monographs.iarc.fr/ENG/Monographs/vol73/ volume73.pdf.

Kojola, W.H., Brenniman, G.R., and Carnow, B.W., 1979, A review of environmental characteristics and health effects of barium in public water supplies: Reviews on Environmental Health, v. 3, no. 1, p. 79-95.

Kolpin, D.W., Barbash, J.E., and Gilliom, R.J., 1998, Occurrence of pesticides in shallow groundwater of the United States-Initial results from the National WaterQuality Assessment Program: Environmental Science and Technology, 1998, v. 32, p. 558-566.

Lee, E.A., and Strahan, A.P., 2003, Methods of analysis by the U.S. Geological Survey Organic Geochemistry Research Group-Determination of acetamide herbicides and their degradation products in water using online solid-phase extraction and high-performance liquid chromatography/ mass spectrometry: U.S. Geological Survey Open-File Report 03-173, $17 \mathrm{p}$.

Lindley, C.E., Stewart, J.T., and Sandstrom, M.W., 1996, Determination of low concentrations of acetochlor in water by automated solid-phase extraction and gas chromatography with mass selective detection: Journal of AOAC International, v. 79, no. 4, p. 962-966.

Madsen, J.E., Sandstrom, M.W., and Zaugg, S.D., 2003, Methods of analysis by the U.S. Geological Survey National Water Quality Laboratory-A method supplement for the determination of Fipronil and degradates in water by gas chromatography/mass spectrometry: U.S. Geological Survey Open-File Report 02-462, 11 p., accessed September 5, 2014, at http://pubs.er.usgs.gov/publication/ ofr02462. 
McGuire, V.L., 2012, Water-level and storage changes in the High Plains aquifer, predevelopment to 2011 and 2009-11: U.S. Geological Survey Scientific Investigations Report 2012-5291, 16 p., accessed September 5, 2014, at http:// pubs.er.usgs.gov/publication/sir20125291.

McMahon, P.B., 2000, A reconnaissance study of the effect of irrigated agriculture on water quality in the Ogallala Formation, central High Plains aquifer: U.S. Geological Survey Fact Sheet 009-00, 6 p., accessed September 5, 2014, at http://pubs.er.usgs.gov/publication/fs00900.

McMahon, P.B., and Böhlke, J.K., 2006, Regional patterns in the isotopic composition of natural and anthropogenic nitrate in ground water, High Plains, USA: Environmental Science and Technology, v. 40, p. 2965-2970.

McMahon, P.B., Dennehy, K.F., Bruce, B.W., Böhlke, J.K., Michel, R.L., Gurdak, J.J., and Hurlbut, D.B., 2006, Storage and transit time of chemicals in thick unsaturated zones under rangeland and irrigated cropland, High Plains, United States: Water Resources Research, v. 42, no. 3, 18 p., accessed September 4, 2014, at http://onlinelibrary. wiley.com/doi/10.1029/2005WR004417/abstract.

McMahon, P.B., Dennehy, K.F., Bruce, B.W., Gurdak, J.J., and Qi, S.L., 2007, Water-quality assessment of the High Plains aquifer, 1999-2004: U.S. Geological Survey Professional Paper 1749, 136 p., accessed September 5, 2014, at http://pubs.er.usgs.gov/publication/pp1749.

Meyer, M.T., Loftin, K.A., Lee, E.A., Hinshaw, G.H., Dietze, J.E., and Scribner, E.A., 2009, Determination of glyphosate, its degradation product aminomethylphosphonic acid, and glufosinate, in water by isotope dilution and online solid-phase extraction and liquid chromatography/tandem mass spectrometry: U.S. Geological Survey Techniques and Methods, book 5, chap. A10, 32 p., accessed September 5, 2014, at http://pubs. er.usgs.gov/publication/tm5A10.

Moore, J.A., 1997, An assessment of boric acid and borax using the IEHR evaluative process for assessing human developmental and reproductive toxicity of agents: Reproductive Toxicology, v. 11, no. 1, p. 123-160.

Mueller, D.K., and Helsel, D.R., 1996, Nutrients in the Nation's water-Too much of a good thing?: U.S. Geological Survey Circular 1136, 24 p., accessed September 5, 2014, at http://pubs.er.usgs.gov/publication/ cir1136.
Mueller, D.K., Martin, J.D., and Lopes, T.J., 1997, Qualitycontrol design for surface-water sampling in the National Water-Quality Assessment program: U.S. Geological Survey Open-File Report 97-223, 17 p., accessed September 5, 2014, at http://pubs.er.usgs.gov/publication/ofr97223.

National Research Council, 1999, Arsenic in drinking water: Washington, D.C., National Academy Press, 273 p.

North Plains Groundwater Conservation District, 2013, Hydrology and groundwater resources 2012-2013, 45 p., accessed September 4, 2014, at http://www.northplainsgcd. org/news/latest-news/88-2013-hydrology-and-groundwaterresources.html.

Patton, C.J., and Kryskalla, J.R., 2003, Methods of analysis by the U.S. Geological Survey National Water Quality Laboratory, evaluation of alkaline persulfate digestion as an alternative to Kjeldahl digestion for determination of total and dissolved nitrogen and phosphorus in water: U.S. Geological Survey Water-Resources Investigations Report 03-4174, 33 p., accessed September 5, 2014, at http://pubs.er.usgs.gov/ publication/wri034174.

Patton, C.J., and Kryskalla, J.R., 2011, Colorimetric determination of nitrate plus nitrite in water by enzymatic reduction, automated discrete analyzer methods: U.S. Geological Survey Techniques and Methods, book 5, chap. B8, 34 p., accessed September 5, 2014, at http://pubs.er.usgs. gov/publication/tm5B8.

Piper, A.M., 1944, A graphic procedure in the geochemical interpretation of water analyses: Transactions American Geophysical Union, v. 25, p. 914-923.

Ryder, P.D., 1996, Groundwater atlas of the United StatesSegment 4, Oklahoma, Texas: U.S. Geological Survey Hydrologic Investigations Atlas 730-E, 30 p., accessed September 5, 2014, at http://pubs.er.usgs.gov/publication/ ha730E.

Sandstrom, M.W., Stroppel, M.E., Foreman, W.T., and Schroeder, M.P., 2001, Methods of analysis by the U.S. Geological Survey National Water Quality LaboratoryDetermination of moderate-use pesticides and selected degradates in water by $\mathrm{C}-18$ solid-phase extraction and gas chromatography/mass spectrometry: U.S. Geological Survey Water-Resources Investigations Report 01-4098, 70 p., accessed September 5, 2014, at http://pubs.er.usgs.gov/ publication/wri20014098. 
Scribner, E.A., Battaglin, W.A., Gilliom, R.J., and Meyer, M.T., 2007, Concentrations of glyphosate, its degradation product, aminomethylphosphonic acid, and glufinosate in ground- and surface-water, rainfall, and soil samples collected in the United States, 2001-06: U.S. Geological Survey Scientific Investigations Report 2007-5122, 111 p., accessed September 5, 2014, at http://pubs.er.usgs.gov/ publication/sir20075122.

Stanton, J.S., and Qi, S.L., 2006, Ground-water quality of the northern High Plains aquifer, 1997, 2002-04: U.S. Geological Survey Scientific Investigations Report 20065138, 59 p., accessed September 5, 2014, at http://pubs. er.usgs.gov/publication/sir20065138.

Steward, D.R., Bruss, P.J., Yang, Xiaoying, Staggenborg, S.A., Welch, S.M., and Apley, M.D., 2013, Tapping unsustainable groundwater stores for agricultural production in the High Plains aquifer of Kansas, projections to 2110: Accessed April 3, 2014, at http://www.pnas.org/content/ early/2013/08/14/1220351110.

Texas Commission on Environmental Quality, 2012, Texas risk reduction program: Texas Commission on Environmental Quality, accessed April 15, 2014, at http:// www.tceq.state.tx.us/remediation/trrp.

Texas Commission on Environmental Quality, 2013, Priority groundwater management areas and groundwater conservation districts - Report to the 83rd Texas Legislature: Texas Commission on Environmental Quality, report no. SFR-053/08, 46 p., accessed July 18, 2014, at http://www.tceq.state.tx.us/assets/public/comm_exec/pubs/ sfr/053_08.pdf.

Texas Water Development Board, 2013, North Plains Groundwater Conservation District 2013-2023 management plan: Texas Water Development Board, 236 p., accessed December 15, 2013, at http://www.twdb.state.tx.us/ groundwater/docs/GCD/npgcd/npgcd_mgmt_plan2013.pdf.

Thelin, G.P., and Stone, W.W., 2010, Method for estimating annual atrazine use for counties in the conterminous United States, 1992-2007: U.S. Geological Survey Scientific Investigations Report 2010-5034, 129 p., accessed September 5, 2014, at http://pubs.er.usgs.gov/publication/ sir20105034.

Torrance, A.G., and Fulton, R.B., Jr., 1987, Zinc-induced hemolytic anemia in a dog: Journal of the American Veterinary Medical Association, v. 191, p. 443-444.

Trimble, D.E., 1980, The geologic story of the Great Plains: U.S. Geological Survey Bulletin 1493, 55 p., accessed July 17, 2014, at http://pubs.er.usgs.gov/publication/b1493.

University of Michigan Health System, 2014, Boron: Accessed June 5, 2014, at http://www.uofmhealth.org/ health-library/hn-2813008\#hn-2813008-uses.
U.S. Department of Agriculture Economic Research Service, 2014, Adoption of genetically engineered crops in the U.S.- - Recent trends in GE adoption: Accessed July 15, 2014, at http://www.ers.usda.gov/data-products/adoption-ofgenetically-engineered-crops-in-the-us/recent-trends-in-geadoption.aspx.

U.S. Department of Commerce, National Climatic Data Center, 2014, Climatic data online search tool: Accessed July 17, 2014, at http://www.ncdc.noaa.gov/oa/ncdc.html.

U.S. Department of Health and Human Services, 2003, Toxicological profile for pyrethrins and pyrethrods: Agency for Toxic Substances and Disease Registry, Division of Health Education and Promotion, publication no. ATSDRHE-CS-2003-0001, 40 p.

U.S. Environmental Protection Agency, 1992, Definition and procedure for the determination of the method detection limit-Revision 1.11: Code of Federal Regulations 40, Protection of the Environment, CFR Part 136, appendix B, p. 565-567.

U.S. Environmental Protection Agency, 1993, Wellhead protection-A guide for small communities: EPA/625/R-93/002, p. 155.

U.S. Environmental Protection Agency, 1994, Tebuthiuron: Reregistration Eligibility Decision (RED) fact sheet, accessed February 5, 2014, at http://www.epa.gov/oppsrrd1/ REDs/factsheets/0054fact.pdf.

U.S. Environmental Protection Agency, 2004, Drinking water health advisory for manganese: Washington, D.C., U.S. Environmental Protection Agency Office of Water (4304T) Health and Ecological Criteria Division, EPA822-R-04-003, 55 p., accessed June 11, 2014, at http:// www.epa.gov/safewater/ccl/pdfs/reg_determine1/support_ cc1_magnese_dwreport.pdf.

U.S. Environmental Protection Agency, 2009, Drinking water contaminants: Accessed September, 3, 2014, at http://water. epa.gov/drink/contaminants/index.cfm\#listmcl.

U.S. Environmental Protection Agency, 2011, Pesticide industry sales and usage, 2006 and 2007 market estimates: U.S. Environmental Protection Agency, 33 p., accessed July 1, 2014, at http://www.epa.gov/opp00001/pestsales/market estimates2007.pdf.

U.S. Environmental Protection Agency, 2012a, Atrazine fact sheet: Accessed February 11, 2014, at http://www.epa.gov/ pesticides/factsheets/atrazine_background.html.

U.S. Environmental Protection Agency, 2012b, Uranium Radiation Protection Program: Accessed February 12, 2014, at http://www.epa.gov/radiation/radionuclides/uranium. html. 
U.S. Environmental Protection Agency, 2013, Current drinking-water standards: Accessed 2013 at http://water. epa.gov/drink/contaminants/index.cfm.

U.S. Environmental Protection Agency, 2014, Pesticide industry sales and usage: Accessed July 15, 2014, at http:// www.epa.gov/opp00001/pestsales/.

U.S. Geological Survey, variously dated, National field manual for the collection of water-quality data: U.S. Geological Survey Techniques of Water-Resources Investigations, book 9, chaps. A1-A9. [Available at http:// pubs.water.usgs.gov/twri9A.]

U.S. Geological Survey, 2007, Glossary: U.S. Geological Survey, accessed June 5, 2014, at http://water.usgs.gov/ nawqa/glos.html.

U.S. Geological Survey, 2014a, USGS water data for Texas: National Water Information System-Web Interface, accessed May 24, 2014, at http://waterdata.usgs.gov/tx/ nwis/nwis.

U.S. Geological Survey, 2014b, The USGS water science school - Contaminants found in groundwater: Accessed July 15, 2014, at http://water.usgs.gov/edu/groundwatercontaminants.html.

U.S. Geological Survey, 2014c, Nickel statistics and information: Accessed July 24, 2014, at http://minerals. usgs.gov/minerals/pubs/commodity/nickel/.

U.S. Salinity Laboratory Staff, 1954, Diagnosis and improvement of saline and alkaline soils: U.S. Department of Agriculture Handbook 60, 160 p.

Welch, A.H., Watkins, S.A., Helsel, D.R., and Focazio, M.J., 2000, Arsenic in ground-water resources of the United States: U.S. Geological Survey Fact Sheet 063-00, 4 p., accessed September 5, 2014, at http://pubs.er.usgs.gov/ publication/fs06300.

Wermund, E.G., 1996, Physiographic map of Texas: Bureau of Economic Geology Map SM0005.

Wilde, F.D., ed., 2004, Cleaning of equipment for water sampling (ver. 2.0): U.S. Geological Survey Techniques of Water-Resources Investigations, book 9, chap. A3, accessed July 17, 2014, at http://pubs.water.usgs.gov/twri9A3/.

Wilde, F.D., Skrobialowski, S.C., and Hart, J.S., 2010, Sampling protocol for post-landfall Deepwater Horizon oil release, Gulf of Mexico, 2010: U.S. Geological Survey Open-File Report 2010-1191, 155 p. [Available at http:// pubs.usgs.gov/of/2010/1191/.]

World Health Organization, 2011a, Guidelines for drinkingwater quality (4th ed.): Accessed June 5, 2014, at http:// whqlibdoc.who.int/publications/2011/9789241548151_eng. pdf?ua $=1$.
World Health Organization, 2011b, Molybdenum in drinking water-Background document for development of WHO guidelines for drinking-water quality: WHO/SDE/ WSH/03.04/11/Rev/1, 10 p., accessed July 15, 2014, at http://www.who.int/water_sanitation_health/dwq/chemicals/ molybdenum.pdf.

Yamaguchi Masayoshi, Takahashi Kouzi, and Okada Shoji, 1983, Zinc-induced hypocalcemia and bone resorption in rats: Toxicology and Applied Pharmacology, v. 67, no. 2, p. 224-228.

Zaugg, S.D., Sandstrom, M.W., Smith, S.G., and Fehlberg, K.M., 1995, Methods of analysis by the U.S. Geological Survey National Water Quality Laboratory-Determination of pesticides in water by $\mathrm{C}-18$ solid-phase extraction and capillary-column gas chromatography/mass spectrometry with selected-ion monitoring: U.S. Geological Survey Open-File Report 95-181, 60 p., accessed September 5, 2014, at http://pubs.er.usgs.gov/publication/ofr95181. 

Appendixes 

Appendix 1. Physical properties and water-quality constituent concentrations measured in environmental samples collected from 30 monitor wells completed in the North Plains Groundwater Conservation District, Texas Panhandle, 2012-13.

[USGS, U.S. Geological Survey; NPGCD, North Plains Groundwater Conservation District; mg/L, milligrams per liter; $\mu$ S/cm, microsiemens per centimeter; nm, nanometer; +/-, plus or minus; NTRU, nephelometric turbidity ratio unit; $\mathrm{CaCO}_{3}$, calcium carbonate; $\mathrm{SiO}_{2}$, silicon dioxide; N, nitrogen; P, phosphorus; +, plus; $\mu \mathrm{g} / \mathrm{L}$, micrograms per liter; CIAT, 2-Chloro-4-isopropylamino-6-amino-s-triazine; AMPA, Aminomethylphosphonic Acid; DCPA, Dacthal; EPTC, S-Ethyl dipropylthiocarbamate; E, estimated; <, less than; --, no data; n, less than the laboratory reporting level (LRL) and greater than or equal to the long-term method detection level (LT-MDL)]

\begin{tabular}{|c|c|c|c|c|c|c|c|c|c|c|c|c|c|}
\hline $\begin{array}{c}\text { USGS station } \\
\text { number }\end{array}$ & $\begin{array}{c}\text { NPGCD } \\
\text { county } \\
\text { well } \\
\text { identifier } \\
\text { (figs. 1, 3, } \\
\mathbf{5 , 6} \text {, and 8) }\end{array}$ & Date & $\begin{array}{l}\text { Dissolved } \\
\text { oxygen, } \\
\text { water, } \\
\text { unfiltered } \\
\text { (mg/L) }\end{array}$ & $\begin{array}{c}\text { pH, } \\
\text { water, } \\
\text { unfiltered, } \\
\text { field } \\
\text { (standard } \\
\text { units) }\end{array}$ & $\begin{array}{c}\text { Specific } \\
\text { conduc- } \\
\text { tance, } \\
\text { water, } \\
\text { unfiltered } \\
\text { ( } \mu \mathrm{S} / \mathrm{cm} \text { at } \\
25 \text { degrees } \\
\text { Celsius) }\end{array}$ & $\begin{array}{c}\text { Temper- } \\
\text { ature, } \\
\text { water } \\
\text { (degrees } \\
\text { Celsius) }\end{array}$ & $\begin{array}{c}\text { Turbidity, water, } \\
\text { unfiltered, } \\
\text { broad band light } \\
\text { source (400-680 } \\
\text { nm), detectors at } \\
\text { multiple angles } \\
\text { including } 90 \\
\text { +/- } 30 \text { degrees, } \\
\text { ratiometric } \\
\text { correctio } \\
\text { (NTRU) }\end{array}$ & $\begin{array}{c}\text { Dissolved } \\
\text { solids } \\
\text { dried at } \\
180 \\
\text { degrees } \\
\text { Celsius, } \\
\text { water, } \\
\text { filtered } \\
\text { (mg/L) }\end{array}$ & $\begin{array}{c}\text { Calcium, } \\
\text { water, } \\
\text { filtered } \\
\text { (mg/L) }\end{array}$ & $\begin{array}{c}\text { Mag- } \\
\text { nesium, } \\
\text { water, } \\
\text { filtered } \\
\text { (mg/L) }\end{array}$ & $\begin{array}{c}\text { Potas- } \\
\text { sium, } \\
\text { water, } \\
\text { filtered } \\
\text { (mg/L) }\end{array}$ & $\begin{array}{c}\text { Sodium- } \\
\text { adsorp- } \\
\text { tion ratio, } \\
\text { water, } \\
\text { filtered } \\
\text { (dimen- } \\
\text { sionless) }\end{array}$ & $\begin{array}{c}\text { Sodium, } \\
\text { water, } \\
\text { filtered } \\
\text { (mg/L) }\end{array}$ \\
\hline 360727102303101 & Da-3688 & $03-22-2013$ & E8.1 & 7.6 & 504 & 19.1 & 0.2 & 308 & 44.9 & 24.6 & 3.41 & 0.64 & 21.5 \\
\hline 362137102533001 & Da-3588 & 03-03-2012 & E1.2 & 8.4 & 672 & 17.8 & 0.5 & 438 & 5.04 & 3.41 & 4.18 & 12.5 & 149 \\
\hline 362308102132801 & Da-3209 & 03-26-2013 & E6.9 & 7.8 & 495 & 18.7 & 0.3 & 309 & 26.5 & 26.9 & 5.62 & 1.42 & 43.3 \\
\hline 362341102375101 & Da-3231 & 03-04-2012 & E8.3 & 7.7 & 648 & 11.7 & 0.1 & 387 & 31.5 & 30.6 & 7.36 & 1.91 & 62.8 \\
\hline 362648102442201 & Da-3589 & 03-03-2012 & E0.1 & 8.7 & 879 & 16.8 & 2.0 & 569 & 2.72 & 1.81 & 2.57 & 23.4 & 203 \\
\hline 361242101341001 & Hn-1917 & 03-02-2012 & E5.1 & 7.5 & 558 & 16.6 & 0.2 & 352 & 47.5 & 29.6 & 6.87 & 0.85 & 30.4 \\
\hline 362700101083801 & Hn-3686 & 03-08-2012 & E7.6 & 7.5 & 860 & 17.7 & 0.6 & 510 & 56.1 & 25.1 & 4.46 & 2.36 & 84.5 \\
\hline 354832102124701 & На-2480 & 03-04-2012 & $\mathrm{E} 4.7$ & 7.6 & 536 & 20.4 & 0.5 & 332 & 37.3 & 23.8 & 5.97 & 1.56 & 49.6 \\
\hline 354833102182901 & На-2470 & $03-22-2013$ & E6.9 & 7.5 & 525 & 20.1 & 0.3 & 347 & 49.3 & 26.3 & 5.71 & 0.56 & 19.6 \\
\hline 355725102145501 & На-2583 & $03-21-2013$ & E7.6 & 7.7 & 434 & 19.6 & 0.8 & 274 & 31.0 & 25.0 & 4.30 & 0.64 & 19.7 \\
\hline 355827102443501 & На-5066 & $03-29-2013$ & E7.2 & 7.5 & 450 & 17.6 & 0.1 & 263 & 47.2 & 16.9 & 3.88 & 0.75 & 23.6 \\
\hline 360241102443401 & Ha-5065 & $03-23-2013$ & E6.4 & 7.6 & 404 & 18.7 & 0.3 & 254 & 34.2 & 22.7 & 3.90 & 0.59 & 18.1 \\
\hline 354810101351501 & $\mathrm{Hu}-4871$ & $03-25-2013$ & E7.5 & 7.6 & 498 & 18.5 & 0.7 & 344 & 37.6 & 29.3 & 5.57 & 0.88 & 29.6 \\
\hline 354919101285301 & $\mathrm{Hu}-4855$ & $03-25-2013$ & E8.8 & 7.7 & 860 & 18.3 & 0.1 & 542 & 85.0 & 36.2 & 4.67 & 0.45 & 19.7 \\
\hline 360332100101401 & Li-0582 & 03-05-2012 & E8.8 & 7.4 & 411 & 17.0 & 0.1 & 258 & 52.1 & 14.6 & 2.85 & 0.51 & 16.2 \\
\hline 360743100161001 & Li-0613 & 03-06-2012 & E9.2 & 7.3 & 455 & 17.7 & 0.1 & 283 & 68.2 & 13.4 & 2.53 & 0.38 & 13.1 \\
\hline 361813100054301 & Li-3687 & $03-06-2012$ & $\mathrm{E} 8.2$ & 7.5 & 721 & 18.1 & 0.1 & 444 & 41.8 & 21.8 & 4.37 & 2.40 & 76.8 \\
\hline 362234100075201 & Li-0567 & $03-07-2012$ & E7.9 & 7.3 & 409 & 17.5 & 0.1 & 259 & 58.2 & 11.7 & 3.06 & 0.34 & 10.8 \\
\hline 362959100065801 & Li-0656 & 03-07-2012 & E8.4 & 7.3 & 474 & 17.4 & 0.2 & 304 & 58.7 & 22.2 & 3.67 & 0.31 & 11.1 \\
\hline 355357101431901 & Mo-2351 & $02-28-2012$ & E6.5 & 7.6 & 501 & 18.3 & 0.4 & 312 & 41.4 & 30.2 & 5.48 & 0.62 & 21.6 \\
\hline 355810101574501 & Mo-2319 & 03-20-2013 & E8.5 & 7.5 & 449 & 19.8 & 0.2 & 318 & 40.2 & 28.2 & 5.92 & 0.62 & 20.8 \\
\hline 360128101500001 & Mo-2389 & $02-29-2012$ & E7.4 & 7.6 & 496 & 18.3 & 0.6 & 308 & 41.8 & 28.1 & 5.34 & 0.59 & 20.1 \\
\hline 360307102071801 & Mo-2350 & $03-21-2013$ & E8.0 & 7.5 & 453 & 18.6 & 0.1 & 297 & 37.4 & 26.3 & 4.18 & 0.58 & 18.8 \\
\hline 360416100445001 & Oc-4465 & $03-27-2013$ & E6.5 & 7.5 & 1,230 & 19.1 & 0.1 & 741 & 45.1 & 29.1 & 5.47 & 4.78 & 168 \\
\hline 361631100444801 & Oc-1291 & $03-27-2013$ & E8.6 & 7.6 & 379 & 17.3 & 0.1 & 251 & 36.2 & 24.3 & 3.74 & 0.22 & 7.12 \\
\hline 362146100542801 & Oc-4196 & 03-08-2012 & E8.9 & 7.4 & 762 & 16.8 & 0.2 & 515 & 92.5 & 26.3 & 6.45 & 0.38 & 16.2 \\
\hline 360546101393301 & Sh-2366 & 03-01-2012 & E6.6 & 7.5 & 478 & 17.7 & 0.3 & 307 & 43.5 & 27.9 & 5.53 & 0.60 & 20.6 \\
\hline 360640101434901 & Sh-2369 & 03-01-2012 & E7.0 & 7.5 & 485 & 18.1 & 0.6 & 298 & 42.3 & 27.2 & 4.96 & 0.61 & 20.7 \\
\hline 362019102035301 & Sh-4136 & 03-26-2013 & E8.1 & 7.7 & 588 & 17.6 & 0.4 & 351 & 37.8 & 40.1 & 7.08 & 0.58 & 21.5 \\
\hline 362035101592801 & Sh-3719 & $03-26-2013$ & E8.1 & 7.7 & 462 & 17.6 & 0.3 & 300 & 30.6 & 30.8 & 6.38 & 0.75 & 24.6 \\
\hline
\end{tabular}


Appendix 1. Physical properties and water-quality constituent concentrations measured in environmental samples collected from 30 monitor wells completed in the North Plains Groundwater Conservation District, Texas Panhandle, 2012-13.-Continued

[USGS, U.S. Geological Survey; NPGCD, North Plains Groundwater Conservation District; mg/L, milligrams per liter; $\mu$ S/cm, microsiemens per centimeter; nm, nanometer; +/-, plus or minus; NTRU, nephelometric turbidity ratio unit; $\mathrm{CaCO}_{3}$, calcium carbonate; $\mathrm{SiO}_{2}$, silicon dioxide; $\mathrm{N}$, nitrogen; $\mathrm{P}$, phosphorus; +, plus; $\mu \mathrm{g} / \mathrm{L}$, micrograms per liter; CIAT, 2-Chloro-4-isopropylamino-6-amino-s-triazine; AMPA, Aminomethylphosphonic Acid; DCPA, Dacthal; EPTC, S-Ethyl dipropylthiocarbamate; E, estimated; <, less than; --, no data; n, less than the laboratory reporting level (LRL) and greater than or equal to the long-term method detection level (LT-MDL)]

\begin{tabular}{|c|c|c|c|c|c|c|c|c|c|c|c|c|c|}
\hline $\begin{array}{c}\text { USGS station } \\
\text { number }\end{array}$ & $\begin{array}{c}\text { NPGCD } \\
\text { county } \\
\text { well } \\
\text { identifier } \\
\text { (figs. 1, 3, } \\
5,6 \text {, and 8) }\end{array}$ & Date & $\begin{array}{c}\text { Alkalinity, } \\
\text { water, filtered, } \\
\text { inflection-point, } \\
\text { incremental } \\
\text { titration } \\
\text { method, field } \\
\left(\mathrm{mg} / \mathrm{L} \text { as } \mathrm{CaCO}_{3}\right)\end{array}$ & $\begin{array}{c}\text { Bromide, } \\
\text { water, } \\
\text { filtered } \\
(\mathrm{mg} / \mathrm{L})\end{array}$ & $\begin{array}{c}\text { Chloride, } \\
\text { water, } \\
\text { filtered } \\
\text { (mg/L) }\end{array}$ & $\begin{array}{c}\text { Fluoride, } \\
\text { water, } \\
\text { filtered } \\
\text { (mg/L) }\end{array}$ & $\begin{array}{c}\text { Silica, } \\
\text { water, } \\
\text { filtered } \\
(\mathrm{mg} / \mathrm{L} \text { as } \\
\left.\mathrm{SiO}_{2}\right)\end{array}$ & $\begin{array}{c}\text { Sulfate, } \\
\text { water, } \\
\text { filtered } \\
(\mathrm{mg} / \mathrm{L})\end{array}$ & $\begin{array}{c}\text { Am- } \\
\text { monia, } \\
\text { water, } \\
\text { filtered } \\
\text { (mg/L } \\
\text { as } \mathrm{N} \text { ) }\end{array}$ & $\begin{array}{l}\text { Nitrite } \\
\text { plus } \\
\text { nitrate, } \\
\text { water, } \\
\text { filtered } \\
\text { (mg/L } \\
\text { as N) }\end{array}$ & $\begin{array}{c}\text { Nitrite, } \\
\text { water, } \\
\text { filtered } \\
\text { (mg/L } \\
\text { as N) }\end{array}$ & $\begin{array}{c}\text { Ortho- } \\
\text { phos- } \\
\text { phate, } \\
\text { water, } \\
\text { filtered } \\
\text { (mg/L } \\
\text { as P) }\end{array}$ & $\begin{array}{c}\text { Total nitrogen, } \\
\text { (nitrite + nitrate } \\
\text { + ammonia } \\
\text { + organic-N) } \\
\text { water, filtered, } \\
\text { analytically } \\
\text { determined } \\
\text { (mg/L) }\end{array}$ \\
\hline 360727102303101 & Da-3688 & $03-22-2013$ & 157 & 0.152 & 24.4 & 0.88 & 25.3 & 27.0 & $<0.010$ & 10.5 & $<0.001$ & 0.009 & 10.5 \\
\hline 362137102533001 & Da-3588 & 03-03-2012 & 299 & 0.119 & 6.41 & 1.13 & 13.8 & 64.5 & 0.105 & $<0.040$ & $<0.001$ & 0.008 & 0.14 \\
\hline 362308102132801 & Da-3209 & 03-26-2013 & 192 & 0.135 & 12.0 & 2.20 & 25.6 & 49.0 & $<0.010$ & 1.65 & 0.001 & 0.009 & 1.72 \\
\hline 362341102375101 & Da-3231 & 03-04-2012 & 199 & 0.303 & 30.6 & 3.61 & 24.6 & 80.2 & $<0.010$ & 4.46 & $<0.001$ & 0.009 & 4.33 \\
\hline 362648102442201 & Da-3589 & 03-03-2012 & 302 & 0.309 & 22.8 & 2.14 & 9.83 & 138 & 0.163 & 0.059 & $<0.001$ & 0.014 & 0.22 \\
\hline 361242101341001 & Hn-1917 & 03-02-2012 & 238 & 0.148 & 8.45 & 1.70 & 39.2 & 44.5 & $<0.010$ & 1.78 & $<0.001$ & 0.014 & 2.07 \\
\hline 362700101083801 & Hn-3686 & 03-08-2012 & 186 & 0.111 & 107 & 1.46 & 31.7 & 78.6 & $<0.010$ & 1.96 & $<0.001$ & 0.016 & 2.1 \\
\hline 354832102124701 & На-2480 & 03-04-2012 & 228 & 0.120 & 9.81 & 1.27 & 30.4 & 49.7 & $<0.010$ & 2.05 & $<0.001$ & 0.012 & 2.19 \\
\hline 354833102182901 & На-2470 & $03-22-2013$ & 199 & 0.131 & 10.6 & 1.00 & 30.4 & 53.0 & $<0.010$ & 2.18 & $<0.001$ & 0.011 & 2.18 \\
\hline 355725102145501 & На-2583 & 03-21-2013 & 167 & 0.092 & 8.81 & 0.88 & 25.9 & 32.5 & $<0.010$ & 2.61 & $<0.001$ & 0.010 & 2.61 \\
\hline 355827102443501 & На-5066 & 03-29-2013 & 182 & 0.147 & 13.3 & 0.98 & 29.3 & 29.2 & $<0.010$ & 1.52 & $<0.001$ & 0.011 & 1.57 \\
\hline 360241102443401 & На-5065 & 03-23-2013 & 169 & 0.110 & 8.56 & 1.50 & 26.8 & 24.0 & $<0.010$ & 1.67 & $<0.001$ & 0.011 & 1.65 \\
\hline 354810101351501 & $\mathrm{Hu}-4871$ & $03-25-2013$ & 195 & 0.087 & 7.31 & 1.50 & 32.3 & 56.5 & $<0.010$ & 1.71 & $<0.001$ & 0.028 & 1.77 \\
\hline 354919101285301 & $\mathrm{Hu}-4855$ & $03-25-2013$ & 110 & 0.540 & 213 & 0.92 & 29.2 & 21.2 & $<0.010$ & 0.908 & $<0.001$ & 0.019 & 0.95 \\
\hline 360332100101401 & Li-0582 & 03-05-2012 & 207 & 0.070 & 4.28 & 0.32 & 33.7 & 6.10 & $<0.010$ & 3.54 & $<0.001$ & 0.013 & 3.73 \\
\hline 360743100161001 & Li-0613 & 03-06-2012 & 211 & 0.120 & 9.95 & 0.49 & 46.2 & 5.84 & $<0.010$ & 4.64 & $<0.001$ & 0.018 & 4.67 \\
\hline 361813100054301 & Li-3687 & 03-06-2012 & 221 & 0.099 & 78.9 & 1.06 & 52.3 & 33.8 & 0.010 & 2.35 & $<0.001$ & 0.021 & 2.51 \\
\hline 362234100075201 & Li-0567 & 03-07-2012 & 200 & 0.036 & 4.15 & 0.52 & 41.6 & 8.66 & 0.010 & 2.00 & $<0.001$ & 0.020 & 2.12 \\
\hline 362959100065801 & Li-0656 & 03-07-2012 & 226 & 0.063 & 12.1 & 0.52 & 51.8 & 11.7 & $<0.010$ & 1.44 & $<0.001$ & 0.018 & 1.60 \\
\hline 355357101431901 & Mo-2351 & 02-28-2012 & 196 & 0.085 & 5.63 & 1.57 & 33.5 & 44.1 & $<0.010$ & 1.44 & $<0.001$ & 0.025 & 1.47 \\
\hline 355810101574501 & Mo-2319 & 03-20-2013 & 184 & 0.159 & 13.5 & 1.10 & 27.9 & 37.2 & $<0.010$ & 2.95 & $<0.001$ & 0.014 & 2.91 \\
\hline 360128101500001 & Mo-2389 & 02-29-2012 & 174 & 0.217 & 24.0 & 1.16 & 27.9 & 28.8 & $<0.010$ & 2.83 & $<0.001$ & 0.014 & 2.87 \\
\hline 360307102071801 & Мo-2350 & $03-21-2013$ & 188 & 0.146 & 11.2 & 1.10 & 26.0 & 27.4 & $<0.010$ & 2.24 & $<0.001$ & 0.010 & 2.25 \\
\hline 360416100445001 & Oc-4465 & $03-27-2013$ & 209 & 0.116 & 237 & 1.40 & 40.8 & 69.6 & $<0.010$ & 1.50 & $<0.001$ & 0.017 & 1.56 \\
\hline 361631100444801 & Oc-1291 & $03-27-2013$ & 182 & 0.054 & 5.68 & 0.25 & 29.5 & 8.45 & $<0.010$ & 1.12 & $<0.001$ & 0.016 & 1.19 \\
\hline 362146100542801 & Oc-4196 & 03-08-2012 & 176 & 0.410 & 115 & 0.89 & 51.1 & 23.9 & $<0.010$ & 3.76 & $<0.001$ & 0.020 & 4.14 \\
\hline 360546101393301 & Sh-2366 & 03-01-2012 & 208 & 0.101 & 7.34 & 1.33 & 33.2 & 36.9 & $<0.010$ & 2.05 & $<0.001$ & 0.012 & 2.11 \\
\hline 360640101434901 & Sh-2369 & 03-01-2012 & 181 & 0.147 & 12.3 & 1.24 & 32.4 & 39.6 & $<0.010$ & 2.18 & $<0.001$ & 0.012 & 2.16 \\
\hline 362019102035301 & Sh-4136 & 03-26-2013 & 182 & 0.191 & 30.9 & 1.30 & 30.8 & 38.0 & $<0.010$ & 11.6 & $<0.001$ & 0.011 & 11.1 \\
\hline 362035101592801 & Sh-3719 & $03-26-2013$ & 195 & 0.098 & 7.17 & 1.50 & 29.1 & 38.8 & $<0.010$ & 2.34 & $<0.001$ & 0.012 & 2.39 \\
\hline
\end{tabular}


Appendix 1. Physical properties and water-quality constituent concentrations measured in environmental samples collected from 30 monitor wells completed in the North Plains Groundwater Conservation District, Texas Panhandle, 2012-13.—Continued

[USGS, U.S. Geological Survey; NPGCD, North Plains Groundwater Conservation District; mg/L, milligrams per liter; $\mu$ S/cm, microsiemens per centimeter; nm, nanometer; +/-, plus or minus; NTRU, nephelometric turbidity ratio unit; $\mathrm{CaCO}_{3}$, calcium carbonate; $\mathrm{SiO}_{2}$, silicon dioxide; N, nitrogen; P, phosphorus; +, plus; $\mu \mathrm{g} / \mathrm{L}$, micrograms per liter; CIAT, 2-Chloro-4-isopropylamino-6-amino-s-triazine; AMPA, Aminomethylphosphonic Acid; DCPA, Dacthal; EPTC, S-Ethyl dipropylthiocarbamate; E, estimated; <, less than; --, no data; n, less than the laboratory reporting level (LRL) and greater than or equal to the long-term method detection level (LT-MDL)]

\begin{tabular}{|c|c|c|c|c|c|c|c|c|c|c|c|c|c|c|}
\hline $\begin{array}{c}\text { USGS station } \\
\text { number }\end{array}$ & $\begin{array}{c}\text { NPGCD } \\
\text { county } \\
\text { well } \\
\text { identifier } \\
\text { (figs. 1, 3, } \\
5,6 \text {, and 8) }\end{array}$ & Date & $\begin{array}{l}\text { Aluminum, } \\
\text { water, } \\
\text { filtered } \\
(\mu \mathrm{g} / \mathrm{L})\end{array}$ & $\begin{array}{c}\text { Barium, } \\
\text { water, } \\
\text { filtered } \\
(\mu \mathrm{g} / \mathrm{L})\end{array}$ & $\begin{array}{c}\text { Beryllium, } \\
\text { water, } \\
\text { filtered } \\
(\mu \mathrm{g} / \mathrm{L})\end{array}$ & $\begin{array}{c}\text { Cad- } \\
\text { mium, } \\
\text { water, } \\
\text { filtered } \\
\text { ( } \mathrm{gg} / \mathrm{L})\end{array}$ & $\begin{array}{c}\text { Chro- } \\
\text { mium, } \\
\text { water, } \\
\text { filtered } \\
\text { ( } \mu \mathrm{g} / \mathrm{L} \text { ) }\end{array}$ & $\begin{array}{c}\text { Cobalt, } \\
\text { water, } \\
\text { filtered } \\
(\mu \mathrm{g} / \mathrm{L})\end{array}$ & $\begin{array}{c}\text { Copper, } \\
\text { water, } \\
\text { filtered } \\
(\mu \mathrm{g} / \mathrm{L})\end{array}$ & $\begin{array}{c}\text { Iron, } \\
\text { water, } \\
\text { filtered } \\
(\mu \mathrm{g} / \mathrm{L})\end{array}$ & $\begin{array}{c}\text { Lead, } \\
\text { water, } \\
\text { filtered } \\
(\mu \mathrm{g} / \mathrm{L})\end{array}$ & $\begin{array}{c}\text { Lithium, } \\
\text { water, } \\
\text { filtered } \\
(\mu \mathrm{g} / \mathrm{L})\end{array}$ & $\begin{array}{c}\text { Man- } \\
\text { ganese, } \\
\text { water, } \\
\text { filtered } \\
\text { ( } \mu \mathrm{g} / \mathrm{L})\end{array}$ & $\begin{array}{c}\text { Molyb- } \\
\text { denum, } \\
\text { water, } \\
\text { filtered } \\
(\mu \mathrm{g} / \mathrm{L})\end{array}$ \\
\hline 360727102303101 & Da-3688 & $03-22-2013$ & 2.4 & 111 & 0.006 & $<0.016$ & 0.91 & 0.089 & $<0.80$ & $<4.0$ & 0.259 & 29.2 & 0.47 & 3.73 \\
\hline 362137102533001 & Da-3588 & 03-03-2012 & 4.4 & 22.9 & 0.007 & 0.019 & $<0.07$ & 0.031 & $<0.80$ & 3.6 & 0.327 & 75.7 & 4.52 & 6.96 \\
\hline 362308102132801 & Da-3209 & $03-26-2013$ & $<2.2$ & 29.1 & 0.007 & 0.047 & 1.5 & 0.068 & $<0.80$ & $<4.0$ & 0.300 & 44.3 & 5.13 & 15.6 \\
\hline 362341102375101 & Da-3231 & 03-04-2012 & $<2.2$ & 41.5 & 0.008 & 0.041 & 0.46 & 0.070 & 1.2 & $<3.2$ & 0.862 & 105 & 0.47 & 17.8 \\
\hline 362648102442201 & Da-3589 & 03-03-2012 & 24.4 & 11.0 & 0.021 & 0.110 & $<0.07$ & 0.053 & $<0.80$ & 9.4 & 0.269 & 90.4 & 4.32 & 41.5 \\
\hline 361242101341001 & Hn-1917 & 03-02-2012 & $<2.2$ & 56.9 & $<0.006$ & $<0.016$ & 1.6 & $<0.021$ & $<0.80$ & $<3.2$ & 0.537 & 68.0 & 0.41 & 6.57 \\
\hline 362700101083801 & $\mathrm{Hn}-3686$ & 03-08-2012 & $<2.2$ & 43.1 & $<0.006$ & 0.019 & 2.1 & 0.098 & 1.2 & $<3.2$ & 0.868 & 54.4 & 1.44 & 5.18 \\
\hline 354832102124701 & На-2480 & 03-04-2012 & $<2.2$ & 65.3 & $<0.006$ & $<0.016$ & 2.7 & 0.022 & $<0.80$ & $<3.2$ & 0.581 & 56.1 & 0.46 & 6.55 \\
\hline 354833102182901 & На-2470 & $03-22-2013$ & 2.7 & 67.8 & 0.007 & $<0.016$ & 1.7 & 0.287 & $<0.80$ & $<4.0$ & 0.307 & 38.3 & 0.80 & 4.98 \\
\hline 355725102145501 & На-2583 & $03-21-2013$ & 2.6 & 76.9 & 0.006 & $<0.016$ & 1.7 & 0.066 & $<0.80$ & $<4.0$ & 0.257 & 31.1 & 0.29 & 6.08 \\
\hline 355827102443501 & На-5066 & 03-29-2013 & 2.3 & 98.3 & $<0.006$ & $<0.016$ & 1.8 & 0.029 & $<0.80$ & $<4.0$ & 0.310 & 34.3 & 0.54 & 5.60 \\
\hline 360241102443401 & На-5065 & $03-23-2013$ & 3.4 & 90.9 & $<0.006$ & $<0.016$ & 1.0 & 0.223 & $<0.80$ & $<4.0$ & 0.267 & 39.3 & 0.65 & 5.19 \\
\hline 354810101351501 & $\mathrm{Hu}-4871$ & $03-25-2013$ & 2.4 & 62.1 & $<0.006$ & 0.019 & 2.2 & 0.072 & $<0.80$ & $<4.0$ & 0.319 & 56.7 & 0.21 & 6.29 \\
\hline 354919101285301 & $\mathrm{Hu}-4855$ & $03-25-2013$ & 2.3 & 340 & $<0.006$ & 0.018 & 0.26 & 0.096 & $<0.80$ & $<4.0$ & 0.322 & 26.7 & 0.21 & 3.92 \\
\hline 360332100101401 & Li-0582 & 03-05-2012 & $<2.2$ & 282 & $<0.006$ & $<0.016$ & 1.2 & $<0.021$ & $<0.80$ & $<3.2$ & 0.476 & 20.8 & 0.46 & 0.286 \\
\hline 360743100161001 & Li-0613 & 03-06-2012 & $<2.2$ & 526 & $<0.006$ & $<0.016$ & 0.93 & 0.029 & 0.81 & $<3.2$ & 0.672 & 35.1 & 0.52 & 0.257 \\
\hline 361813100054301 & Li-3687 & 03-06-2012 & $<2.2$ & 123 & $<0.006$ & $<0.016$ & 1.7 & 0.034 & $<0.80$ & 4.7 & 0.573 & 46.5 & 0.45 & 2.46 \\
\hline 362234100075201 & Li-0567 & 03-07-2012 & $<2.2$ & 262 & $<0.006$ & $<0.016$ & 0.66 & 0.036 & 1.0 & $<3.2$ & 0.809 & 24.1 & 0.49 & 1.55 \\
\hline 362959100065801 & Li-0656 & 03-07-2012 & $<2.2$ & 205 & $<0.006$ & $<0.016$ & 1.1 & 0.031 & $<0.80$ & $<3.2$ & 0.591 & 32.0 & 0.51 & 0.779 \\
\hline 355357101431901 & Mo-2351 & 02-28-2012 & $<2.2$ & 55.4 & $<0.006$ & 0.020 & 2.0 & 0.100 & $<0.80$ & $<3.2$ & 0.620 & 73.2 & 0.55 & 7.60 \\
\hline 355810101574501 & Mo-2319 & 03-20-2013 & $<2.2$ & 84.5 & $<0.006$ & 0.017 & 2.2 & 0.059 & $<0.80$ & $<4.0$ & 0.208 & 39.3 & 0.35 & 5.88 \\
\hline 360128101500001 & Mo-2389 & 02-29-2012 & $<2.2$ & 83.1 & $<0.006$ & 0.024 & 1.7 & 0.032 & $<0.80$ & $<3.2$ & 0.405 & 41.3 & 0.65 & 7.62 \\
\hline 360307102071801 & Mo-2350 & $03-21-2013$ & 2.6 & 88.1 & $<0.006$ & $<0.016$ & 1.2 & 0.060 & $<0.80$ & $<4.0$ & 0.323 & 35.6 & 0.20 & 5.96 \\
\hline 360416100445001 & Oc-4465 & $03-27-2013$ & 2.9 & 228 & 0.006 & 0.017 & 2.6 & 0.025 & $<0.80$ & $<4.0$ & 0.333 & 60.4 & 2.62 & 4.19 \\
\hline 361631100444801 & Oc-1291 & $03-27-2013$ & 3.7 & 234 & $<0.006$ & $<0.016$ & 0.26 & 0.044 & $<0.80$ & $<4.0$ & 0.340 & 82.8 & 0.20 & 1.18 \\
\hline 362146100542801 & Oc-4196 & 03-08-2012 & $<2.2$ & 144 & $<0.006$ & $<0.016$ & 0.53 & 0.040 & $<0.80$ & $<3.2$ & 0.528 & 64.7 & 0.66 & 3.00 \\
\hline 360546101393301 & Sh-2366 & 03-01-2012 & $<2.2$ & 65.2 & $<0.006$ & $<0.016$ & 2.4 & $<0.021$ & $<0.80$ & $<3.2$ & 0.470 & 51.9 & 0.36 & 6.22 \\
\hline 360640101434901 & Sh-2369 & 03-01-2012 & $<2.2$ & 67.5 & $<0.006$ & $<0.016$ & 1.9 & $<0.021$ & $<0.80$ & 3.4 & 0.515 & 45.7 & 0.31 & 5.84 \\
\hline 362019102035301 & Sh-4136 & $03-26-2013$ & $<2.2$ & 89.7 & 0.008 & 0.028 & 0.79 & 0.319 & 1.2 & $<4.0$ & 0.483 & 50.6 & 26.5 & 8.52 \\
\hline 362035101592801 & Sh-3719 & $03-26-2013$ & 2.3 & 55.5 & 0.007 & 0.032 & 1.8 & 0.047 & 1.3 & $<4.0$ & 0.642 & 41.8 & 0.22 & 15.1 \\
\hline
\end{tabular}


Appendix 1. Physical properties and water-quality constituent concentrations measured in environmental samples collected from 30 monitor wells completed in the North Plains Groundwater Conservation District, Texas Panhandle, 2012-13.-Continued

[USGS, U.S. Geological Survey; NPGCD, North Plains Groundwater Conservation District; mg/L, milligrams per liter; $\mu$ S/cm, microsiemens per centimeter; nm, nanometer; +/-, plus or minus; NTRU, nephelometric turbidity ratio unit; $\mathrm{CaCO}_{3}$, calcium carbonate; $\mathrm{SiO}_{2}$, silicon dioxide; $\mathrm{N}$, nitrogen; $\mathrm{P}$, phosphorus; +, plus; $\mu \mathrm{g} / \mathrm{L}$, micrograms per liter; CIAT, 2-Chloro-4-isopropylamino-6-amino-s-triazine; AMPA, Aminomethylphosphonic Acid; DCPA, Dacthal; EPTC, S-Ethyl dipropylthiocarbamate; E, estimated; <, less than; --, no data; n, less than the laboratory reporting level (LRL) and greater than or equal to the long-term method detection level (LT-MDL)]

\begin{tabular}{|c|c|c|c|c|c|c|c|c|c|c|c|c|c|}
\hline $\begin{array}{c}\text { USGS station } \\
\text { number }\end{array}$ & $\begin{array}{c}\text { NPGCD } \\
\text { county } \\
\text { well } \\
\text { identifier } \\
\text { (figs. 1, 3, } \\
\text { 5, 6, and 8) }\end{array}$ & Date & $\begin{array}{c}\text { Nickel, } \\
\text { water, } \\
\text { filtered } \\
(\mu \mathrm{g} / \mathrm{L})\end{array}$ & $\begin{array}{c}\text { Silver, } \\
\text { water, } \\
\text { filtered } \\
(\mu \mathrm{g} / \mathrm{L})\end{array}$ & $\begin{array}{c}\text { Strontium, } \\
\text { water, } \\
\text { filtered } \\
(\mu \mathrm{g} / \mathrm{L})\end{array}$ & $\begin{array}{c}\text { Thallium, } \\
\text { water, } \\
\text { filtered } \\
\text { ( } \mu \mathrm{g} / \mathrm{L})\end{array}$ & $\begin{array}{c}\text { Vanadium, } \\
\text { water, } \\
\text { filtered } \\
(\mu \mathrm{g} / \mathrm{L})\end{array}$ & $\begin{array}{c}\text { Zinc, } \\
\text { water, } \\
\text { filtered } \\
(\mu \mathrm{g} / \mathrm{L})\end{array}$ & $\begin{array}{c}\text { Antimony, } \\
\text { water, } \\
\text { filtered } \\
(\mu \mathrm{g} / \mathrm{L})\end{array}$ & $\begin{array}{c}\text { Arsenic, } \\
\text { water, } \\
\text { filtered } \\
(\mu \mathrm{g} / \mathrm{L})\end{array}$ & $\begin{array}{c}\text { Boron, } \\
\text { water, } \\
\text { filtered } \\
(\mu \mathrm{g} / \mathrm{L})\end{array}$ & $\begin{array}{c}\text { Selenium, } \\
\text { water, } \\
\text { filtered } \\
(\mu \mathrm{g} / \mathrm{L})\end{array}$ & $\begin{array}{c}\text { Uranium } \\
\text { (natural), } \\
\text { water, } \\
\text { filtered } \\
\text { ( } \mu \mathrm{g} / \mathrm{L})\end{array}$ \\
\hline 360727102303101 & Da-3688 & $03-22-2013$ & 0.27 & $<0.005$ & 943 & $<0.010$ & 12.2 & 4.0 & 0.030 & 1.8 & 90 & 3.4 & 4.06 \\
\hline 362137102533001 & Da-3588 & 03-03-2012 & 0.11 & $<0.005$ & 263 & $<0.010$ & 0.10 & 68.3 & $<0.027$ & 0.18 & 371 & $<0.03$ & 1.11 \\
\hline 362308102132801 & Da-3209 & $03-26-2013$ & 0.19 & $<0.005$ & 988 & $<0.010$ & 22.9 & 21.1 & 0.063 & 3.9 & 161 & 3.3 & 12.9 \\
\hline 362341102375101 & Da-3231 & 03-04-2012 & 0.24 & $<0.005$ & 1,110 & $<0.010$ & 28.6 & 52.6 & 0.053 & 4.5 & 373 & 5.8 & 19.7 \\
\hline 362648102442201 & Da-3589 & 03-03-2012 & $<0.09$ & $<0.005$ & 88.9 & $<0.010$ & 0.08 & $<1.4$ & $<0.027$ & 0.10 & 781 & $<0.03$ & 0.071 \\
\hline 361242101341001 & Hn-1917 & 03-02-2012 & 0.19 & $<0.005$ & 1,170 & 0.123 & 18.6 & 19.2 & $<0.027$ & 3.2 & 189 & 3.0 & 11.9 \\
\hline 362700101083801 & Hn-3686 & 03-08-2012 & 0.41 & $<0.005$ & 1,180 & $<0.010$ & 19.1 & 22.7 & 0.068 & 3.6 & 157 & 1.9 & 8.44 \\
\hline 354832102124701 & На-2480 & 03-04-2012 & 0.24 & $<0.005$ & 1,050 & $<0.010$ & 15.1 & 46.3 & $<0.027$ & 1.7 & 174 & 3.1 & 11.4 \\
\hline 354833102182901 & На-2470 & $03-22-2013$ & 0.33 & $<0.005$ & 1,130 & $<0.010$ & 15.3 & 5.0 & 0.075 & 2.8 & 142 & 3.6 & 9.61 \\
\hline 355725102145501 & На-2583 & $03-21-2013$ & 0.18 & $<0.005$ & 962 & $<0.010$ & 17.0 & 2.3 & 0.030 & 1.5 & 129 & 4.6 & 6.27 \\
\hline 355827102443501 & На-5066 & $03-29-2013$ & 0.26 & 0.005 & 813 & $<0.010$ & 8.5 & 3.7 & 0.039 & 1.8 & 93 & 3.6 & 6.14 \\
\hline 360241102443401 & На-5065 & $03-23-2013$ & 0.23 & 0.005 & 920 & $<0.010$ & 14.4 & 4.2 & 0.078 & 2.6 & 122 & 2.5 & 5.34 \\
\hline 354810101351501 & $\mathrm{Hu}-4871$ & $03-25-2013$ & 0.17 & 0.007 & 1,030 & $<0.010$ & 15.6 & 1.6 & 0.028 & 3.4 & 128 & 2.1 & 6.88 \\
\hline 354919101285301 & $\mathrm{Hu}-4855$ & $03-25-2013$ & 0.35 & $<0.005$ & 1,290 & $<0.010$ & 7.7 & 4.9 & 0.043 & 1.9 & 32 & 0.23 & 2.08 \\
\hline 360332100101401 & Li-0582 & 03-05-2012 & 0.30 & $<0.005$ & 652 & $<0.010$ & 8.7 & 12.7 & 0.041 & 1.4 & 44 & 0.61 & 1.94 \\
\hline 360743100161001 & Li-0613 & $03-06-2012$ & 0.35 & $<0.005$ & 580 & $<0.010$ & 7.2 & 4.4 & 0.083 & 1.3 & 39 & 0.96 & 2.45 \\
\hline 361813100054301 & Li-3687 & 03-06-2012 & 0.27 & $<0.005$ & 900 & $<0.010$ & 29.3 & 2.3 & 0.055 & 6.9 & 138 & 1.4 & 6.83 \\
\hline 362234100075201 & Li-0567 & $03-07-2012$ & 0.32 & $<0.005$ & 593 & $<0.010$ & 12.9 & 6.8 & 0.099 & 3.0 & 50 & 0.64 & 3.19 \\
\hline 362959100065801 & Li-0656 & $03-07-2012$ & 0.30 & $<0.005$ & 1,080 & $<0.010$ & 19.1 & 16.5 & 0.066 & 3.7 & 85 & 1.3 & 7.85 \\
\hline 355357101431901 & Mo-2351 & $02-28-2012$ & 0.25 & $<0.005$ & 1,080 & $<0.010$ & 9.5 & 8.1 & 0.027 & 1.8 & 130 & 2.3 & 8.11 \\
\hline 355810101574501 & Mo-2319 & $03-20-2013$ & 0.33 & $<0.005$ & 1,070 & $<0.010$ & 13.0 & 3.7 & 0.036 & 1.4 & 118 & 3.9 & 6.82 \\
\hline 360128101500001 & Mo-2389 & $02-29-2012$ & 0.26 & $<0.005$ & 1,150 & $<0.010$ & 7.0 & 42.3 & $<0.027$ & 0.99 & 114 & 4.4 & 7.09 \\
\hline 360307102071801 & Mo-2350 & $03-21-2013$ & 0.16 & 0.008 & 1,010 & $<0.010$ & 13.6 & 2.4 & $<0.027$ & 1.4 & 111 & 2.7 & 6.93 \\
\hline 360416100445001 & Oc-4465 & $03-27-2013$ & 0.23 & $<0.005$ & 1,170 & $<0.010$ & 16.5 & 3.2 & 0.062 & 3.8 & 139 & 2.7 & 7.16 \\
\hline 361631100444801 & Oc-1291 & $03-27-2013$ & 0.25 & 0.011 & 1,010 & $<0.010$ & 26.4 & 5.2 & 0.073 & 5.5 & 51 & 0.42 & 3.88 \\
\hline 362146100542801 & Oc-4196 & 03-08-2012 & 0.47 & $<0.005$ & 1,040 & $<0.010$ & 15.0 & 16.7 & 0.070 & 3.5 & 107 & 4.8 & 4.04 \\
\hline 360546101393301 & Sh-2366 & 03-01-2012 & 0.16 & $<0.005$ & 1,130 & $<0.010$ & 11.6 & 4.6 & $<0.027$ & 1.6 & 142 & 3.9 & 8.62 \\
\hline 360640101434901 & Sh-2369 & 03-01-2012 & 0.17 & $<0.005$ & 1,130 & $<0.010$ & 13.0 & 19.4 & 0.029 & 1.9 & 120 & 4.4 & 7.29 \\
\hline 362019102035301 & Sh-4136 & $03-26-2013$ & 1.5 & $<0.005$ & 1,500 & $<0.010$ & 14.8 & 3.2 & 0.048 & 2.5 & 144 & 2.5 & 10.9 \\
\hline 362035101592801 & Sh-3719 & $03-26-2013$ & 0.20 & $<0.005$ & 1,200 & $<0.010$ & 13.6 & 10.7 & 0.042 & 2.1 & 136 & 2.6 & 12.0 \\
\hline
\end{tabular}


Appendix 1. Physical properties and water-quality constituent concentrations measured in environmental samples collected from 30 monitor wells completed in the North Plains Groundwater Conservation District, Texas Panhandle, 2012-13.—Continued

[USGS, U.S. Geological Survey; NPGCD, North Plains Groundwater Conservation District; mg/L, milligrams per liter; $\mu$ S/cm, microsiemens per centimeter; nm, nanometer; +/-, plus or minus; NTRU, nephelometric turbidity ratio unit; $\mathrm{CaCO}_{3}$, calcium carbonate; $\mathrm{SiO}_{2}$, silicon dioxide; $\mathrm{N}$, nitrogen; P, phosphorus; +, plus; $\mu \mathrm{g} / \mathrm{L}$, micrograms per liter; CIAT, 2-Chloro-4-isopropylamino-6-amino-s-triazine; AMPA, Aminomethylphosphonic Acid; DCPA, Dacthal; EPTC, S-Ethyl dipropylthiocarbamate; E, estimated; <, less than; --, no data; n, less than the laboratory reporting level (LRL) and greater than or equal to the long-term method detection level (LT-MDL)]

\begin{tabular}{|c|c|c|c|c|c|c|c|c|c|c|c|}
\hline $\begin{array}{c}\text { USGS station } \\
\text { number }\end{array}$ & $\begin{array}{c}\text { NPGCD } \\
\text { county } \\
\text { well } \\
\text { identifier } \\
\text { (figs. 1, 3, } \\
5,6 \text {, and 8) }\end{array}$ & Date & $\begin{array}{c}\text { 1-Naphthol, } \\
\text { water, filtered } \\
\text { (0.7 micron } \\
\text { glass fiber } \\
\text { filter), } \\
\text { recoverable } \\
\text { ( } \mu \mathrm{g} / \mathrm{L})\end{array}$ & $\begin{array}{c}\text { 2,6-Diethyl- } \\
\text { aniline, } \\
\text { water, filtered } \\
\text { (0.7 micron } \\
\text { glass fiber } \\
\text { filter), } \\
\text { recoverable } \\
\text { ( } \mu \mathrm{g} / \mathrm{L})\end{array}$ & $\begin{array}{c}\text { 2-[(2-Ethyl- } \\
\text { 6-methylphe- } \\
\text { nyl)amino]-2- } \\
\text { oxoethane- } \\
\text { sulfonic } \\
\text { acid, water, } \\
\text { filtered, } \\
\text { recoverable } \\
\text { ( } \mu \mathrm{g} / \mathrm{L} \text { ) }\end{array}$ & $\begin{array}{c}\text { 2-Chloro- } \\
\text { 2',6'-diethyl- } \\
\text { acetanilide, } \\
\text { water, } \\
\text { filtered, } \\
\text { recoverable } \\
(\mu \mathrm{g} / \mathrm{L})\end{array}$ & $\begin{array}{c}\text { CIAT, } \\
\text { water, } \\
\text { filtered, } \\
\text { recoverable } \\
(\mu \mathrm{g} / \mathrm{L})\end{array}$ & $\begin{array}{c}\text { 2-Ethyl- } \\
\text { 6-methylan- } \\
\text { iline, water, } \\
\text { filtered, } \\
\text { recoverable } \\
\text { ( } \mu \mathrm{g} / \mathrm{L})\end{array}$ & $\begin{array}{l}\text { 3,4-Dichloro- } \\
\text { aniline, } \\
\text { water, } \\
\text { filtered, } \\
\text { recoverable } \\
(\mu \mathrm{g} / \mathrm{L})\end{array}$ & $\begin{array}{c}\text { 3,5-Dichloro- } \\
\text { aniline, } \\
\text { water, } \\
\text { filtered, } \\
\text { recoverable } \\
\text { ( } \mu \mathrm{g} / \mathrm{L} \text { ) }\end{array}$ & $\begin{array}{l}\text { 4-Chloro- } \\
\text { 2-methylphe- } \\
\text { nol, water, } \\
\text { filtered, } \\
\text { recoverable } \\
\text { ( } \mu \mathrm{g} / \mathrm{L})\end{array}$ \\
\hline 360727102303101 & Da-3688 & $03-22-2013$ & -- & -- & -- & -- & -- & -- & -- & -- & -- \\
\hline 362137102533001 & Da-3588 & 03-03-2012 & -- & -- & -- & -- & -- & -- & -- & -- & -- \\
\hline 362308102132801 & Da-3209 & $03-26-2013$ & -- & -- & -- & -- & -- & -- & -- & -- & -- \\
\hline 362341102375101 & Da-3231 & 03-04-2012 & -- & -- & -- & -- & -- & -- & -- & -- & -- \\
\hline 362648102442201 & Da-3589 & 03-03-2012 & $<0.0360$ & $<0.0060$ & $<0.02$ & $<0.010$ & $<0.006$ & $<0.010$ & $<0.0060$ & $<0.006$ & $<0.0080$ \\
\hline 361242101341001 & Hn-1917 & 03-02-2012 & $<0.0360$ & $<0.0060$ & $<0.02$ & $<0.010$ & E0.023 & $<0.010$ & $<0.0060$ & $<0.006$ & $<0.0080$ \\
\hline 362700101083801 & Hn-3686 & 03-08-2012 & -- & -- & -- & -- & -- & -- & -- & -- & -- \\
\hline 354832102124701 & На-2480 & 03-04-2012 & $<0.0360$ & $<0.0060$ & $<0.02$ & $<0.010$ & $<0.006$ & $<0.010$ & $<0.0060$ & $<0.006$ & $<0.0080$ \\
\hline 354833102182901 & На-2470 & $03-22-2013$ & -- & -- & -- & -- & -- & -- & -- & -- & -- \\
\hline 355725102145501 & На-2583 & $03-21-2013$ & -- & -- & -- & -- & -- & -- & -- & -- & -- \\
\hline 355827102443501 & На-5066 & 03-29-2013 & -- & -- & -- & -- & -- & -- & -- & -- & -- \\
\hline 360241102443401 & На-5065 & 03-23-2013 & -- & -- & -- & -- & -- & -- & -- & -- & -- \\
\hline 354810101351501 & $\mathrm{Hu}-4871$ & $03-25-2013$ & -- & -- & -- & -- & -- & -- & -- & -- & -- \\
\hline 354919101285301 & $\mathrm{Hu}-4855$ & $03-25-2013$ & -- & -- & -- & -- & -- & -- & -- & -- & -- \\
\hline 360332100101401 & Li-0582 & 03-05-2012 & -- & -- & -- & -- & -- & -- & -- & -- & -- \\
\hline 360743100161001 & Li-0613 & 03-06-2012 & -- & -- & -- & -- & -- & -- & -- & -- & -- \\
\hline 361813100054301 & Li-3687 & $03-06-2012$ & -- & -- & -- & -- & -- & -- & -- & -- & -- \\
\hline 362234100075201 & Li-0567 & 03-07-2012 & -- & -- & -- & -- & -- & -- & -- & -- & -- \\
\hline 362959100065801 & Li-0656 & 03-07-2012 & $<0.0360$ & $<0.0060$ & $<0.02$ & $<0.010$ & $<0.006$ & $<0.010$ & $<0.0060$ & $<0.006$ & $<0.0080$ \\
\hline 355357101431901 & Mo-2351 & $02-28-2012$ & $<0.0360$ & $<0.0060$ & $<0.02$ & $<0.010$ & $<0.006$ & $<0.010$ & $<0.0060$ & $<0.006$ & $<0.0080$ \\
\hline 355810101574501 & Mo-2319 & 03-20-2013 & -- & -- & -- & -- & -- & -- & -- & -- & -- \\
\hline 360128101500001 & Mo-2389 & $02-29-2012$ & -- & -- & -- & -- & -- & -- & -- & -- & -- \\
\hline 360307102071801 & Mo-2350 & 03-21-2013 & -- & -- & -- & -- & -- & -- & -- & -- & -- \\
\hline 360416100445001 & Oc-4465 & $03-27-2013$ & -- & -- & -- & -- & -- & -- & -- & -- & -- \\
\hline 361631100444801 & Oc-1291 & $03-27-2013$ & -- & -- & -- & -- & -- & -- & -- & -- & -- \\
\hline 362146100542801 & Oc-4196 & 03-08-2012 & -- & -- & -- & -- & -- & -- & -- & -- & -- \\
\hline 360546101393301 & Sh-2366 & 03-01-2012 & -- & -- & -- & -- & -- & -- & -- & -- & -- \\
\hline 360640101434901 & Sh-2369 & 03-01-2012 & $<0.0360$ & $<0.0060$ & $<0.02$ & $<0.010$ & E0.018 & $<0.010$ & $<0.0060$ & $<0.006$ & $<0.0080$ \\
\hline 362019102035301 & Sh-4136 & 03-26-2013 & -- & -- & -- & -- & -- & -- & -- & -- & -- \\
\hline 362035101592801 & Sh-3719 & 03-26-2013 & -- & -- & -- & -- & -- & -- & -- & -- & -- \\
\hline
\end{tabular}


Appendix 1. Physical properties and water-quality constituent concentrations measured in environmental samples collected from 30 monitor wells completed in the North Plains Groundwater Conservation District, Texas Panhandle, 2012-13.-Continued

[USGS, U.S. Geological Survey; NPGCD, North Plains Groundwater Conservation District; mg/L, milligrams per liter; $\mu$ S/cm, microsiemens per centimeter; nm, nanometer; +/-, plus or minus; NTRU, nephelometric turbidity ratio unit; $\mathrm{CaCO}_{3}$, calcium carbonate; $\mathrm{SiO}_{2}$, silicon dioxide; $\mathrm{N}$, nitrogen; $\mathrm{P}$, phosphorus; +, plus; $\mu \mathrm{g} / \mathrm{L}$, micrograms per liter; CIAT, 2-Chloro-4-isopropylamino-6-amino-s-triazine; AMPA, Aminomethylphosphonic Acid; DCPA, Dacthal; EPTC, S-Ethyl dipropylthiocarbamate; E, estimated; <, less than; --, no data; n, less than the laboratory reporting level (LRL) and greater than or equal to the long-term method detection level (LT-MDL)]

\begin{tabular}{|c|c|c|c|c|c|c|c|c|c|c|c|}
\hline $\begin{array}{c}\text { USGS station } \\
\text { number }\end{array}$ & $\begin{array}{c}\text { NPGCD } \\
\text { county } \\
\text { well } \\
\text { identifier } \\
\text { (figs. 1, 3, } \\
5,6 \text {, and 8) }\end{array}$ & Date & $\begin{array}{l}\text { Acetochlor } \\
\text { oxanilic } \\
\text { acid, water, } \\
\text { filtered } \\
\text { (0.7 micron } \\
\text { glass fiber } \\
\text { filter), } \\
\text { recoverable } \\
\text { ( } \mu \mathrm{g} / \mathrm{L})\end{array}$ & $\begin{array}{c}\text { Acetochlor } \\
\text { sulfonic } \\
\text { acid, water, } \\
\text { filtered ( } 0.7 \\
\text { micron glass } \\
\text { fiber filter), } \\
\text { recoverable } \\
\text { ( } \mu \mathrm{g} / \mathrm{L})\end{array}$ & $\begin{array}{l}\text { Acetochlor } \\
\text { sulfinylacetic } \\
\text { acid,water, } \\
\text { filtered, } \\
\text { recoverable } \\
\text { ( } \mu \mathrm{g} / \mathrm{L})\end{array}$ & $\begin{array}{l}\text { Acetochlor, } \\
\text { water, } \\
\text { filtered, } \\
\text { recoverable } \\
\text { ( } \mu \mathrm{g} / \mathrm{L} \text { ) }\end{array}$ & $\begin{array}{c}\text { Alachlor } \\
\text { oxanilic } \\
\text { acid, water, } \\
\text { filtered (0.7 } \\
\text { micron glass } \\
\text { fiber filter), } \\
\text { recoverable } \\
\text { ( } \mu \mathrm{g} / \mathrm{L})\end{array}$ & $\begin{array}{c}\text { Alachlor } \\
\text { sulfonic } \\
\text { acid, water, } \\
\text { filtered ( } 0.7 \\
\text { micron glass } \\
\text { fiber filter), } \\
\text { recoverable } \\
\text { ( } \mu \mathrm{g} / \mathrm{L} \text { ) }\end{array}$ & $\begin{array}{l}\text { Alachlor } \\
\text { sulfinylacetic } \\
\text { acid, water, } \\
\text { filtered, } \\
\text { recoverable } \\
\text { ( } \mu \mathrm{g} / \mathrm{L})\end{array}$ & $\begin{array}{c}\text { Alachlor, } \\
\text { water, } \\
\text { filtered, } \\
\text { recoverable } \\
\text { ( } \mu \mathrm{g} / \mathrm{L})\end{array}$ & $\begin{array}{l}\text { alpha- } \\
\text { Endosulfan, } \\
\text { water, } \\
\text { filtered, } \\
\text { recoverable } \\
(\mu \mathrm{g} / \mathrm{L})\end{array}$ \\
\hline 360727102303101 & Da-3688 & $03-22-2013$ & -- & -- & -- & -- & -- & -- & -- & -- & -- \\
\hline 362137102533001 & Da-3588 & 03-03-2012 & -- & -- & -- & -- & -- & -- & -- & -- & -- \\
\hline 362308102132801 & Da-3209 & $03-26-2013$ & -- & -- & -- & -- & -- & -- & -- & -- & -- \\
\hline 362341102375101 & Da-3231 & 03-04-2012 & -- & -- & -- & -- & -- & -- & -- & -- & -- \\
\hline 362648102442201 & Da-3589 & 03-03-2012 & $<0.02$ & $<0.02$ & $<0.02$ & $<0.010$ & $<0.02$ & $<0.02$ & $<0.02$ & $<0.008$ & $<0.006$ \\
\hline 361242101341001 & Hn-1917 & 03-02-2012 & $<0.02$ & $<0.02$ & $<0.02$ & $<0.010$ & $<0.02$ & $<0.02$ & $<0.02$ & $<0.008$ & $<0.006$ \\
\hline 362700101083801 & Hn-3686 & 03-08-2012 & -- & -- & -- & -- & -- & -- & -- & -- & -- \\
\hline 354832102124701 & На-2480 & 03-04-2012 & $<0.02$ & $<0.02$ & $<0.02$ & $<0.010$ & $<0.02$ & $<0.02$ & $<0.02$ & $<0.008$ & $<0.006$ \\
\hline 354833102182901 & На-2470 & $03-22-2013$ & -- & -- & -- & -- & -- & -- & -- & -- & -- \\
\hline 355725102145501 & На-2583 & $03-21-2013$ & -- & -- & -- & -- & -- & -- & -- & -- & -- \\
\hline 355827102443501 & На-5066 & $03-29-2013$ & -- & -- & -- & -- & -- & -- & -- & -- & -- \\
\hline 360241102443401 & На-5065 & $03-23-2013$ & -- & -- & -- & -- & -- & -- & -- & -- & -- \\
\hline 354810101351501 & $\mathrm{Hu}-4871$ & $03-25-2013$ & -- & -- & -- & -- & -- & -- & -- & -- & -- \\
\hline 354919101285301 & $\mathrm{Hu}-4855$ & $03-25-2013$ & -- & -- & -- & -- & -- & -- & -- & -- & -- \\
\hline 360332100101401 & Li-0582 & 03-05-2012 & -- & -- & -- & -- & -- & -- & -- & -- & -- \\
\hline 360743100161001 & Li-0613 & 03-06-2012 & -- & -- & -- & -- & -- & -- & -- & -- & -- \\
\hline 361813100054301 & Li-3687 & 03-06-2012 & -- & -- & -- & -- & -- & -- & -- & -- & -- \\
\hline 362234100075201 & Li-0567 & 03-07-2012 & -- & -- & -- & -- & -- & -- & -- & -- & -- \\
\hline 362959100065801 & Li-0656 & 03-07-2012 & $<0.02$ & $<0.02$ & $<0.02$ & $<0.010$ & $<0.02$ & $<0.02$ & $<0.02$ & $<0.008$ & $<0.006$ \\
\hline 355357101431901 & Mo-2351 & 02-28-2012 & $<0.02$ & $<0.02$ & $<0.02$ & $<0.010$ & $<0.02$ & $<0.02$ & $<0.02$ & $<0.008$ & $<0.006$ \\
\hline 355810101574501 & Mo-2319 & 03-20-2013 & -- & -- & -- & -- & -- & -- & -- & -- & -- \\
\hline 360128101500001 & Mo-2389 & 02-29-2012 & -- & -- & -- & -- & -- & -- & -- & -- & -- \\
\hline 360307102071801 & Mo-2350 & $03-21-2013$ & -- & -- & -- & -- & -- & -- & -- & -- & -- \\
\hline 360416100445001 & Oc-4465 & $03-27-2013$ & -- & -- & -- & -- & -- & -- & -- & -- & -- \\
\hline 361631100444801 & Oc-1291 & $03-27-2013$ & -- & -- & -- & -- & -- & -- & -- & -- & -- \\
\hline 362146100542801 & Oc-4196 & 03-08-2012 & -- & -- & -- & -- & -- & -- & -- & -- & -- \\
\hline 360546101393301 & Sh-2366 & 03-01-2012 & -- & -- & -- & -- & -- & -- & -- & -- & -- \\
\hline 360640101434901 & Sh-2369 & 03-01-2012 & $<0.02$ & $<0.02$ & $<0.02$ & $<0.010$ & $<0.02$ & $<0.02$ & $<0.02$ & $<0.008$ & $<0.006$ \\
\hline 362019102035301 & Sh-4136 & 03-26-2013 & -- & -- & -- & -- & -- & -- & -- & -- & -- \\
\hline 362035101592801 & Sh-3719 & $03-26-2013$ & -- & -- & -- & -- & -- & -- & -- & -- & -- \\
\hline
\end{tabular}


Appendix 1. Physical properties and water-quality constituent concentrations measured in environmental samples collected from 30 monitor wells completed in the North Plains Groundwater Conservation District, Texas Panhandle, 2012-13.—Continued

[USGS, U.S. Geological Survey; NPGCD, North Plains Groundwater Conservation District; mg/L, milligrams per liter; $\mu$ S/cm, microsiemens per centimeter; nm, nanometer; +/-, plus or minus; NTRU, nephelometric turbidity ratio unit; $\mathrm{CaCO}_{3}$, calcium carbonate; $\mathrm{SiO}_{2}$, silicon dioxide; $\mathrm{N}$, nitrogen; P, phosphorus; +, plus; $\mu \mathrm{g} / \mathrm{L}$, micrograms per liter; CIAT, 2-Chloro-4-isopropylamino-6-amino-s-triazine; AMPA, Aminomethylphosphonic Acid; DCPA, Dacthal; EPTC, S-Ethyl dipropylthiocarbamate; E, estimated; <, less than; --, no data; n, less than the laboratory reporting level (LRL) and greater than or equal to the long-term method detection level (LT-MDL)]

\begin{tabular}{|c|c|c|c|c|c|c|c|c|c|c|c|}
\hline $\begin{array}{c}\text { USGS station } \\
\text { number }\end{array}$ & $\begin{array}{c}\text { NPGCD } \\
\text { county } \\
\text { well } \\
\text { identifier } \\
\text { (figs. 1, 3, } \\
\mathbf{5 , 6} \text {, and } 8 \text { ) }\end{array}$ & Date & $\begin{array}{c}\text { AMPA } \\
\text { water, } \\
\text { filtered } \\
\text { (0.7 micron } \\
\text { glass fiber } \\
\text { filter), } \\
\text { recoverable } \\
(\mu \mathrm{g} / \mathrm{L}) \\
\end{array}$ & $\begin{array}{l}\text { Atrazine, } \\
\text { water, } \\
\text { filtered, } \\
\text { recoverable } \\
\text { ( } \mu \mathrm{g} / \mathrm{L})\end{array}$ & $\begin{array}{c}\text { Azinphos- } \\
\text { methyl } \\
\text { oxygen } \\
\text { analog, } \\
\text { water, filtered, } \\
\text { recoverable } \\
(\mu \mathrm{g} / \mathrm{L})\end{array}$ & $\begin{array}{c}\text { Azinphos- } \\
\text { methyl, water, } \\
\text { filtered (0.7 } \\
\text { micron glass } \\
\text { fiber filter), } \\
\text { recoverable } \\
(\mu \mathrm{g} / \mathrm{L})\end{array}$ & $\begin{array}{c}\text { Benfluralin, } \\
\text { water, filtered } \\
\text { (0.7 micron } \\
\text { glass fiber } \\
\text { filter), recov- } \\
\text { erable } \\
(\mu \mathrm{g} / \mathrm{L})\end{array}$ & $\begin{array}{c}\text { Carbaryl, } \\
\text { water, filtered } \\
\text { (0.7 micron } \\
\text { glass fiber } \\
\text { filter), recov- } \\
\text { erable } \\
(\mu \mathrm{g} / \mathrm{L})\end{array}$ & $\begin{array}{c}\text { Carbofuran, } \\
\text { water, } \\
\text { filtered ( } 0.7 \\
\text { micron glass } \\
\text { fiber filter), } \\
\text { recoverable } \\
\text { ( } \mu \mathrm{g} / \mathrm{L})\end{array}$ & $\begin{array}{l}\text { Chlorpyrifos } \\
\text { oxygen } \\
\text { analog, } \\
\text { water, } \\
\text { filtered, } \\
\text { recoverable } \\
(\mu \mathrm{g} / \mathrm{L})\end{array}$ & $\begin{array}{l}\text { Chlorpyrifos, } \\
\text { water, } \\
\text { filtered, } \\
\text { recoverable } \\
\text { ( } \mu \mathrm{g} / \mathrm{L})\end{array}$ \\
\hline 360727102303101 & Da-3688 & $03-22-2013$ & -- & -- & -- & -- & -- & $\begin{array}{ll}- \\
-\end{array}$ & -- & -- & -- \\
\hline 362137102533001 & Da-3588 & 03-03-2012 & -- & -- & -- & -- & -- & -- & -- & -- & -- \\
\hline 362308102132801 & Da-3209 & 03-26-2013 & -- & -- & -- & -- & -- & -- & -- & -- & -- \\
\hline 362341102375101 & Da-3231 & 03-04-2012 & -- & -- & -- & -- & -- & -- & -- & -- & -- \\
\hline 362648102442201 & Da-3589 & 03-03-2012 & $<0.02$ & $<0.008$ & $<0.042$ & $<0.120$ & $<0.014$ & $<0.060$ & $<0.060$ & $<0.08$ & $<0.0036$ \\
\hline 361242101341001 & Hn-1917 & 03-02-2012 & $<0.02$ & 0.008 & $<0.042$ & $<0.120$ & $<0.014$ & $<0.060$ & $<0.060$ & $<0.08$ & $<0.0036$ \\
\hline 362700101083801 & Hn-3686 & 03-08-2012 & -- & -- & -- & -- & -- & -- & -- & -- & -- \\
\hline 354832102124701 & На-2480 & 03-04-2012 & $<0.02$ & $<0.008$ & $<0.042$ & $<0.120$ & $<0.014$ & $<0.060$ & $<0.060$ & $<0.08$ & $<0.0036$ \\
\hline 354833102182901 & На-2470 & $03-22-2013$ & -- & -- & -- & -- & -- & -- & -- & -- & -- \\
\hline 355725102145501 & На-2583 & $03-21-2013$ & -- & -- & -- & -- & -- & -- & -- & -- & -- \\
\hline 355827102443501 & На-5066 & 03-29-2013 & -- & -- & -- & -- & -- & -- & -- & -- & -- \\
\hline 360241102443401 & На-5065 & $03-23-2013$ & -- & -- & -- & -- & -- & -- & -- & -- & -- \\
\hline 354810101351501 & $\mathrm{Hu}-4871$ & $03-25-2013$ & -- & -- & -- & -- & -- & -- & -- & -- & -- \\
\hline 354919101285301 & $\mathrm{Hu}-4855$ & $03-25-2013$ & -- & -- & -- & -- & -- & -- & -- & -- & -- \\
\hline 360332100101401 & Li-0582 & 03-05-2012 & -- & -- & -- & -- & -- & -- & -- & -- & -- \\
\hline 360743100161001 & Li-0613 & 03-06-2012 & -- & -- & -- & -- & -- & -- & -- & -- & -- \\
\hline 361813100054301 & Li-3687 & 03-06-2012 & -- & -- & -- & -- & -- & -- & -- & -- & -- \\
\hline 362234100075201 & Li-0567 & 03-07-2012 & -- & -- & -- & -- & -- & -- & -- & -- & -- \\
\hline 362959100065801 & Li-0656 & 03-07-2012 & $<0.02$ & $<0.008$ & $<0.042$ & $<0.120$ & $<0.014$ & $<0.060$ & $<0.060$ & $<0.08$ & $<0.0036$ \\
\hline 355357101431901 & Mo-2351 & 02-28-2012 & $<0.02$ & $<0.008$ & $<0.042$ & $<0.120$ & $<0.014$ & $<0.060$ & $<0.060$ & $<0.08$ & $<0.0036$ \\
\hline 355810101574501 & Mo-2319 & 03-20-2013 & -- & -- & -- & -- & -- & -- & -- & -- & -- \\
\hline 360128101500001 & Мo-2389 & 02-29-2012 & -- & -- & -- & -- & -- & -- & -- & -- & -- \\
\hline 360307102071801 & Mo-2350 & $03-21-2013$ & -- & -- & -- & -- & -- & -- & -- & -- & -- \\
\hline 360416100445001 & Oc-4465 & $03-27-2013$ & -- & -- & -- & -- & -- & -- & -- & -- & -- \\
\hline 361631100444801 & Oc-1291 & $03-27-2013$ & -- & -- & -- & -- & -- & -- & -- & -- & -- \\
\hline 362146100542801 & Oc-4196 & 03-08-2012 & -- & -- & -- & -- & -- & -- & -- & -- & -- \\
\hline 360546101393301 & Sh-2366 & 03-01-2012 & -- & -- & -- & -- & -- & -- & -- & -- & -- \\
\hline 360640101434901 & Sh-2369 & 03-01-2012 & $<0.02$ & 0.013 & $<0.042$ & $<0.120$ & $<0.014$ & $<0.060$ & $<0.060$ & $<0.08$ & $<0.0036$ \\
\hline 362019102035301 & Sh-4136 & 03-26-2013 & -- & -- & -- & -- & -- & -- & -- & -- & -- \\
\hline 362035101592801 & Sh-3719 & 03-26-2013 & -- & -- & -- & -- & -- & -- & -- & -- & -- \\
\hline
\end{tabular}


Appendix 1. Physical properties and water-quality constituent concentrations measured in environmental samples collected from 30 monitor wells completed in the North Plains Groundwater Conservation District, Texas Panhandle, 2012-13.-Continued

[USGS, U.S. Geological Survey; NPGCD, North Plains Groundwater Conservation District; mg/L, milligrams per liter; $\mu$ S/cm, microsiemens per centimeter; nm, nanometer; +/-, plus or minus; NTRU, nephelometric turbidity ratio unit; $\mathrm{CaCO}_{3}$, calcium carbonate; $\mathrm{SiO}_{2}$, silicon dioxide; $\mathrm{N}$, nitrogen; P, phosphorus; +, plus; $\mu \mathrm{g} / \mathrm{L}$, micrograms per liter; CIAT, 2-Chloro-4-isopropylamino-6-amino-s-triazine; AMPA, Aminomethylphosphonic Acid; DCPA, Dacthal; EPTC, S-Ethyl dipropylthiocarbamate; E, estimated; <, less than; --, no data; n, less than the laboratory reporting level (LRL) and greater than or equal to the long-term method detection level (LT-MDL)]

\begin{tabular}{|c|c|c|c|c|c|c|c|c|c|c|c|}
\hline $\begin{array}{c}\text { USGS station } \\
\text { number }\end{array}$ & $\begin{array}{c}\text { NPGCD } \\
\text { county } \\
\text { well } \\
\text { identifier } \\
\text { (figs. 1, 3, } \\
\mathbf{5 , 6} \text {, and 8) }\end{array}$ & Date & $\begin{array}{c}\text { cis-Permethrin, } \\
\text { water, filtered } \\
\text { (0.7 micron } \\
\text { glass fiber } \\
\text { filter), } \\
\text { recoverable } \\
(\mu \mathrm{g} / \mathrm{L})\end{array}$ & $\begin{array}{c}\text { cis-Propi- } \\
\text { conazole, } \\
\text { water, } \\
\text { filtered, } \\
\text { recoverable } \\
\text { ( } \mu \mathrm{g} / \mathrm{L})\end{array}$ & $\begin{array}{c}\text { Cyanazine, } \\
\text { water, } \\
\text { filtered, } \\
\text { recoverable } \\
\text { ( } \mu \mathrm{g} / \mathrm{L})\end{array}$ & $\begin{array}{l}\text { Cyfluthrin, } \\
\text { water, } \\
\text { filtered, } \\
\text { recoverable } \\
\text { ( } \mu \mathrm{g} / \mathrm{L})\end{array}$ & $\begin{array}{c}\text { Cyperme- } \\
\text { thrin, } \\
\text { water, } \\
\text { filtered, } \\
\text { recoverable } \\
\text { ( } \mu \mathrm{g} / \mathrm{L})\end{array}$ & $\begin{array}{l}\text { DCPA, water, } \\
\text { filtered (0.7 } \\
\text { micron glass } \\
\text { fiber filter), } \\
\text { recoverable } \\
\text { ( } \mu \mathrm{g} / \mathrm{L})\end{array}$ & $\begin{array}{l}\text { Dechloro- } \\
\text { acetochlor, } \\
\text { water, } \\
\text { filtered, } \\
\text { recoverable } \\
\text { ( } \mu \mathrm{g} / \mathrm{L} \text { ) }\end{array}$ & $\begin{array}{l}\text { Dechloro- } \\
\text { alachlor, } \\
\text { water, } \\
\text { filtered, } \\
\text { recoverable } \\
\text { ( } \mu \mathrm{g} / \mathrm{L} \text { ) }\end{array}$ & $\begin{array}{c}\text { Dechloro- } \\
\text { dimethenamid, } \\
\text { water, } \\
\text { filtered, } \\
\text { recoverable } \\
\text { ( } \mu \mathrm{g} / \mathrm{L})\end{array}$ \\
\hline 360727102303101 & Da-3688 & $03-22-2013$ & -- & -- & -- & -- & -- & -- & -- & -- & -- \\
\hline 362137102533001 & Da-3588 & 03-03-2012 & -- & -- & -- & -- & -- & -- & -- & -- & -- \\
\hline 362308102132801 & Da-3209 & $03-26-2013$ & -- & -- & -- & -- & -- & -- & -- & -- & -- \\
\hline 362341102375101 & Da-3231 & 03-04-2012 & -- & -- & -- & -- & -- & -- & -- & -- & -- \\
\hline 362648102442201 & Da-3589 & 03-03-2012 & $<0.010$ & $<0.008$ & $<0.022$ & $<0.016$ & $<0.020$ & $<0.0076$ & $<0.02$ & $<0.02$ & $<0.02$ \\
\hline 361242101341001 & Hn-1917 & 03-02-2012 & $<0.010$ & $<0.008$ & $<0.022$ & $<0.016$ & $<0.020$ & $<0.0076$ & $<0.02$ & $<0.02$ & $<0.02$ \\
\hline 362700101083801 & Hn-3686 & 03-08-2012 & -- & -- & -- & -- & -- & -- & -- & -- & -- \\
\hline 354832102124701 & На-2480 & 03-04-2012 & $<0.010$ & $<0.008$ & $<0.022$ & $<0.016$ & $<0.020$ & $<0.0076$ & $<0.02$ & $<0.02$ & $<0.02$ \\
\hline 354833102182901 & На-2470 & $03-22-2013$ & -- & -- & -- & -- & -- & -- & -- & -- & -- \\
\hline 355725102145501 & На-2583 & $03-21-2013$ & -- & -- & -- & -- & -- & -- & -- & -- & -- \\
\hline 355827102443501 & На-5066 & 03-29-2013 & -- & -- & -- & -- & -- & -- & -- & -- & -- \\
\hline 360241102443401 & На-5065 & $03-23-2013$ & -- & -- & -- & -- & -- & -- & -- & -- & -- \\
\hline 354810101351501 & $\mathrm{Hu}-4871$ & $03-25-2013$ & -- & -- & -- & -- & -- & -- & -- & -- & -- \\
\hline 354919101285301 & Hu-4855 & $03-25-2013$ & -- & -- & -- & -- & -- & -- & -- & -- & -- \\
\hline 360332100101401 & Li-0582 & 03-05-2012 & -- & -- & -- & -- & -- & -- & -- & -- & -- \\
\hline 360743100161001 & Li-0613 & 03-06-2012 & -- & -- & -- & -- & -- & -- & -- & -- & -- \\
\hline 361813100054301 & Li-3687 & 03-06-2012 & -- & -- & -- & -- & -- & -- & -- & -- & -- \\
\hline 362234100075201 & Li-0567 & 03-07-2012 & -- & -- & -- & -- & -- & -- & -- & -- & -- \\
\hline 362959100065801 & Li-0656 & 03-07-2012 & $<0.010$ & $<0.008$ & $<0.022$ & $<0.016$ & $<0.020$ & $<0.0076$ & $<0.02$ & $<0.02$ & $<0.02$ \\
\hline 355357101431901 & Mo-2351 & 02-28-2012 & $<0.010$ & $<0.008$ & $<0.022$ & $<0.016$ & $<0.020$ & $<0.0076$ & $<0.02$ & $<0.02$ & $<0.02$ \\
\hline 355810101574501 & Mo-2319 & $03-20-2013$ & -- & -- & -- & -- & -- & -- & -- & -- & -- \\
\hline 360128101500001 & Мo-2389 & 02-29-2012 & -- & -- & -- & -- & -- & -- & -- & -- & -- \\
\hline 360307102071801 & Mo-2350 & $03-21-2013$ & -- & -- & -- & -- & -- & -- & -- & -- & -- \\
\hline 360416100445001 & Oc-4465 & $03-27-2013$ & -- & -- & -- & -- & -- & -- & -- & -- & -- \\
\hline 361631100444801 & Oc-1291 & $03-27-2013$ & -- & -- & -- & -- & -- & -- & -- & -- & -- \\
\hline 362146100542801 & Oc-4196 & 03-08-2012 & -- & -- & -- & -- & -- & -- & -- & -- & -- \\
\hline 360546101393301 & Sh-2366 & 03-01-2012 & -- & -- & -- & -- & -- & -- & -- & -- & -- \\
\hline 360640101434901 & Sh-2369 & 03-01-2012 & $<0.010$ & $<0.008$ & $<0.022$ & $<0.016$ & $<0.020$ & $<0.0076$ & $<0.02$ & $<0.02$ & $<0.02$ \\
\hline 362019102035301 & Sh-4136 & $03-26-2013$ & -- & -- & -- & -- & -- & -- & -- & -- & -- \\
\hline 362035101592801 & Sh-3719 & $03-26-2013$ & -- & -- & -- & -- & -- & -- & -- & -- & -- \\
\hline
\end{tabular}


Appendix 1. Physical properties and water-quality constituent concentrations measured in environmental samples collected from 30 monitor wells completed in the North Plains Groundwater Conservation District, Texas Panhandle, 2012-13.—Continued

[USGS, U.S. Geological Survey; NPGCD, North Plains Groundwater Conservation District; mg/L, milligrams per liter; $\mu$ S/cm, microsiemens per centimeter; nm, nanometer; +/-, plus or minus; NTRU, nephelometric turbidity ratio unit; $\mathrm{CaCO}_{3}$, calcium carbonate; $\mathrm{SiO}_{2}$, silicon dioxide; $\mathrm{N}$, nitrogen; P, phosphorus; +, plus; $\mu \mathrm{g} / \mathrm{L}$, micrograms per liter; CIAT, 2-Chloro-4-isopropylamino-6-amino-s-triazine; AMPA, Aminomethylphosphonic Acid; DCPA, Dacthal; EPTC, S-Ethyl dipropylthiocarbamate; E, estimated; <, less than; --, no data; n, less than the laboratory reporting level (LRL) and greater than or equal to the long-term method detection level (LT-MDL)]

\begin{tabular}{|c|c|c|c|c|c|c|c|c|c|c|c|}
\hline $\begin{array}{c}\text { USGS station } \\
\text { number }\end{array}$ & $\begin{array}{c}\text { NPGCD } \\
\text { county } \\
\text { well } \\
\text { identifier } \\
\text { (figs. 1, 3, } \\
5,6 \text {, and 8) }\end{array}$ & Date & $\begin{array}{l}\text { Dechloro- } \\
\text { metolachlor, } \\
\text { water, } \\
\text { filtered, } \\
\text { recoverable } \\
\text { ( } \mu \mathrm{g} / \mathrm{L} \text { ) }\end{array}$ & $\begin{array}{l}\text { Desulfinyl- } \\
\text { fipronil } \\
\text { amide, water, } \\
\text { filtered, } \\
\text { recoverable } \\
\text { ( } \mu \mathrm{g} / \mathrm{L})\end{array}$ & $\begin{array}{l}\text { Desulfinyl- } \\
\text { fipronil, } \\
\text { water, } \\
\text { filtered, } \\
\text { recoverable } \\
\text { ( } \mu \mathrm{g} / \mathrm{L} \text { ) }\end{array}$ & $\begin{array}{l}\text { Diazinon, } \\
\text { water, } \\
\text { filtered, } \\
\text { recoverable } \\
\text { ( } \mu \mathrm{g} / \mathrm{L})\end{array}$ & $\begin{array}{l}\text { Dichlorvos, } \\
\text { water, } \\
\text { filtered, } \\
\text { recoverable } \\
\text { ( } \mu \mathrm{g} / \mathrm{L})\end{array}$ & $\begin{array}{l}\text { Dicrotophos, } \\
\text { water, } \\
\text { filtered, } \\
\text { recoverable } \\
\text { ( } \mu \mathrm{g} / \mathrm{L})\end{array}$ & $\begin{array}{l}\text { Dieldrin, } \\
\text { water, } \\
\text { filtered, } \\
\text { recover- } \\
\text { able } \\
\text { ( } \mu \mathrm{g} / \mathrm{L})\end{array}$ & $\begin{array}{l}\text { Dimethenamid } \\
\text { oxanilic } \\
\text { acid, water, } \\
\text { filtered, } \\
\text { recoverable } \\
\text { ( } \mu \mathrm{g} / \mathrm{L})\end{array}$ & $\begin{array}{l}\text { Dimethe- } \\
\text { namid } \\
\text { sulfonic } \\
\text { acid, water, } \\
\text { filtered, } \\
\text { recoverable } \\
\text { ( } \mu \mathrm{g} / \mathrm{L}) \\
\end{array}$ \\
\hline 360727102303101 & Da-3688 & $03-22-2013$ & -- & -- & -- & -- & -- & -- & -- & -- & -- \\
\hline 362137102533001 & Da-3588 & 03-03-2012 & -- & -- & -- & -- & -- & -- & -- & -- & -- \\
\hline 362308102132801 & Da-3209 & 03-26-2013 & -- & -- & -- & -- & -- & -- & -- & -- & -- \\
\hline 362341102375101 & Da-3231 & 03-04-2012 & -- & -- & -- & -- & -- & -- & -- & -- & -- \\
\hline 362648102442201 & Da-3589 & 03-03-2012 & $<0.02$ & $<0.029$ & $<0.012$ & $<0.0060$ & $<0.04$ & $<0.08$ & $<0.008$ & $<0.02$ & $<0.02$ \\
\hline 361242101341001 & Hn-1917 & 03-02-2012 & $<0.02$ & $<0.029$ & $<0.012$ & $<0.0060$ & $<0.04$ & $<0.08$ & $<0.008$ & $<0.02$ & $<0.02$ \\
\hline 362700101083801 & Hn-3686 & 03-08-2012 & -- & -- & -- & -- & -- & -- & -- & -- & -- \\
\hline 354832102124701 & На-2480 & 03-04-2012 & $<0.02$ & $<0.029$ & $<0.012$ & $<0.0060$ & $<0.04$ & $<0.08$ & $<0.008$ & $<0.02$ & $<0.02$ \\
\hline 354833102182901 & На-2470 & $03-22-2013$ & -- & -- & -- & -- & -- & -- & -- & -- & -- \\
\hline 355725102145501 & На-2583 & 03-21-2013 & -- & -- & -- & -- & -- & -- & -- & -- & -- \\
\hline 355827102443501 & На-5066 & 03-29-2013 & -- & -- & -- & -- & -- & -- & -- & -- & -- \\
\hline 360241102443401 & На-5065 & $03-23-2013$ & -- & -- & -- & -- & -- & -- & -- & -- & -- \\
\hline 354810101351501 & Hu-4871 & $03-25-2013$ & -- & -- & -- & -- & -- & -- & -- & -- & -- \\
\hline 354919101285301 & $\mathrm{Hu}-4855$ & $03-25-2013$ & -- & -- & -- & -- & -- & -- & -- & -- & -- \\
\hline 360332100101401 & Li-0582 & 03-05-2012 & -- & -- & -- & -- & -- & -- & -- & -- & -- \\
\hline 360743100161001 & Li-0613 & 03-06-2012 & -- & -- & -- & -- & -- & -- & -- & -- & -- \\
\hline 361813100054301 & Li-3687 & 03-06-2012 & -- & -- & -- & -- & -- & -- & -- & -- & -- \\
\hline 362234100075201 & Li-0567 & 03-07-2012 & -- & -- & -- & -- & -- & -- & -- & -- & -- \\
\hline 362959100065801 & Li-0656 & 03-07-2012 & $<0.02$ & $<0.029$ & $<0.012$ & $<0.0060$ & $<0.04$ & $<0.08$ & $<0.008$ & $<0.02$ & $<0.02$ \\
\hline 355357101431901 & Mo-2351 & $02-28-2012$ & $<0.02$ & $<0.029$ & $<0.012$ & $<0.0060$ & $<0.04$ & $<0.08$ & $<0.008$ & $<0.02$ & $<0.02$ \\
\hline 355810101574501 & Mo-2319 & $03-20-2013$ & -- & -- & -- & -- & -- & -- & -- & -- & -- \\
\hline 360128101500001 & Mo-2389 & 02-29-2012 & -- & -- & -- & -- & -- & -- & -- & -- & -- \\
\hline 360307102071801 & Mo-2350 & $03-21-2013$ & -- & -- & -- & -- & -- & -- & -- & -- & -- \\
\hline 360416100445001 & Oc-4465 & $03-27-2013$ & -- & -- & -- & -- & -- & -- & -- & -- & -- \\
\hline 361631100444801 & Oc-1291 & $03-27-2013$ & -- & -- & -- & -- & -- & -- & -- & -- & -- \\
\hline 362146100542801 & Oc-4196 & 03-08-2012 & -- & -- & -- & -- & -- & -- & -- & -- & -- \\
\hline 360546101393301 & Sh-2366 & 03-01-2012 & -- & -- & -- & -- & -- & -- & -- & -- & -- \\
\hline 360640101434901 & Sh-2369 & 03-01-2012 & $<0.02$ & $<0.029$ & $<0.012$ & $<0.0060$ & $<0.04$ & $<0.08$ & $<0.008$ & $<0.02$ & $<0.02$ \\
\hline 362019102035301 & Sh-4136 & $03-26-2013$ & -- & -- & -- & -- & -- & -- & -- & -- & -- \\
\hline 362035101592801 & Sh-3719 & $03-26-2013$ & -- & -- & -- & -- & -- & -- & -- & -- & -- \\
\hline
\end{tabular}


Appendix 1. Physical properties and water-quality constituent concentrations measured in environmental samples collected from 30 monitor wells completed in the North Plains Groundwater Conservation District, Texas Panhandle, 2012-13.-Continued

[USGS, U.S. Geological Survey; NPGCD, North Plains Groundwater Conservation District; mg/L, milligrams per liter; $\mu$ S/cm, microsiemens per centimeter; nm, nanometer; +/-, plus or minus; NTRU, nephelometric turbidity ratio unit; $\mathrm{CaCO}_{3}$, calcium carbonate; $\mathrm{SiO}_{2}$, silicon dioxide; $\mathrm{N}$, nitrogen; $\mathrm{P}$, phosphorus; +, plus; $\mu \mathrm{g} / \mathrm{L}$, micrograms per liter; CIAT, 2-Chloro-4-isopropylamino-6-amino-s-triazine; AMPA, Aminomethylphosphonic Acid; DCPA, Dacthal; EPTC, S-Ethyl dipropylthiocarbamate; E, estimated; <, less than; --, no data; n, less than the laboratory reporting level (LRL) and greater than or equal to the long-term method detection level (LT-MDL)]

\begin{tabular}{|c|c|c|c|c|c|c|c|c|c|c|c|}
\hline $\begin{array}{c}\text { USGS station } \\
\text { number }\end{array}$ & $\begin{array}{c}\text { NPGCD } \\
\text { county } \\
\text { well } \\
\text { identifier } \\
\text { (figs. 1, 3, } \\
5,6 \text {, and 8) }\end{array}$ & Date & $\begin{array}{l}\text { Dimethe- } \\
\text { namid, } \\
\text { water, } \\
\text { filtered, } \\
\text { recoverable } \\
\text { ( } \mu \mathrm{g} / \mathrm{L} \text { ) }\end{array}$ & $\begin{array}{c}\text { Dimethoate, } \\
\text { water, filtered } \\
\text { (0.7 micron } \\
\text { glass fiber } \\
\text { filter), } \\
\text { recoverable } \\
(\mu \mathrm{g} / \mathrm{L})\end{array}$ & $\begin{array}{c}\text { Disulfoton } \\
\text { sulfone, } \\
\text { water, } \\
\text { filtered, } \\
\text { recoverable } \\
\text { ( } \mu \mathrm{g} / \mathrm{L})\end{array}$ & $\begin{array}{c}\text { Disulfoton, } \\
\text { water, filtered } \\
(0.7 \text { micron } \\
\text { glass fiber } \\
\text { filter), recov- } \\
\text { erable } \\
(\mu \mathrm{g} / \mathrm{L})\end{array}$ & $\begin{array}{l}\text { Endosulfan } \\
\text { sulfate, } \\
\text { water, } \\
\text { filtered, } \\
\text { recoverable } \\
\text { ( } \mu \mathrm{g} / \mathrm{L})\end{array}$ & $\begin{array}{c}\text { EPTC, water, } \\
\text { filtered (0.7 } \\
\text { micron glass } \\
\text { fiber filter), } \\
\text { recoverable } \\
\text { ( } \mu \mathrm{g} / \mathrm{L})\end{array}$ & $\begin{array}{c}\text { Ethion } \\
\text { monoxon, } \\
\text { water, } \\
\text { filtered, } \\
\text { recoverable } \\
\text { ( } \mu \mathrm{g} / \mathrm{L} \text { ) }\end{array}$ & $\begin{array}{c}\text { Ethion, } \\
\text { water, } \\
\text { filtered, } \\
\text { recoverable } \\
\text { ( } \mu \mathrm{g} / \mathrm{L})\end{array}$ & $\begin{array}{c}\text { Ethopro- } \\
\text { phos, water, } \\
\text { filtered ( } 0.7 \\
\text { micron glass } \\
\text { fiber filter), } \\
\text { recoverable } \\
(\mu \mathrm{g} / \mathrm{L})\end{array}$ \\
\hline 360727102303101 & Da-3688 & $03-22-2013$ & -- & -- & -- & -- & -- & -- & -- & -- & -- \\
\hline 362137102533001 & Da-3588 & 03-03-2012 & -- & -- & -- & -- & -- & -- & -- & -- & -- \\
\hline 362308102132801 & Da-3209 & $03-26-2013$ & -- & -- & -- & -- & -- & -- & -- & -- & -- \\
\hline 362341102375101 & Da-3231 & 03-04-2012 & -- & -- & -- & -- & -- & -- & -- & -- & -- \\
\hline 362648102442201 & Da-3589 & 03-03-2012 & $<0.02$ & $<0.010$ & $<0.014$ & $<0.040$ & $<0.016$ & $<0.0056$ & $<0.021$ & $<0.010$ & $<0.016$ \\
\hline 361242101341001 & Hn-1917 & 03-02-2012 & $<0.02$ & $<0.010$ & $<0.014$ & $<0.040$ & $<0.016$ & $<0.0056$ & $<0.021$ & $<0.010$ & $<0.016$ \\
\hline 362700101083801 & Hn-3686 & 03-08-2012 & -- & -- & -- & -- & -- & -- & -- & -- & -- \\
\hline 354832102124701 & На-2480 & 03-04-2012 & $<0.02$ & $<0.010$ & $<0.014$ & $<0.040$ & $<0.016$ & $<0.0056$ & $<0.021$ & $<0.010$ & $<0.016$ \\
\hline 354833102182901 & На-2470 & $03-22-2013$ & -- & -- & -- & -- & -- & -- & -- & -- & -- \\
\hline 355725102145501 & На-2583 & $03-21-2013$ & -- & -- & -- & -- & -- & -- & -- & -- & -- \\
\hline 355827102443501 & На-5066 & 03-29-2013 & -- & -- & -- & -- & -- & -- & -- & -- & -- \\
\hline 360241102443401 & На-5065 & 03-23-2013 & -- & -- & -- & -- & -- & -- & -- & -- & -- \\
\hline 354810101351501 & $\mathrm{Hu}-4871$ & $03-25-2013$ & -- & -- & -- & -- & -- & -- & -- & -- & -- \\
\hline 354919101285301 & $\mathrm{Hu}-4855$ & $03-25-2013$ & -- & -- & -- & -- & -- & -- & -- & -- & -- \\
\hline 360332100101401 & Li-0582 & $03-05-2012$ & -- & -- & -- & -- & -- & -- & -- & -- & -- \\
\hline 360743100161001 & Li-0613 & 03-06-2012 & -- & -- & -- & -- & -- & -- & -- & -- & -- \\
\hline 361813100054301 & Li-3687 & 03-06-2012 & -- & -- & -- & -- & -- & -- & -- & -- & -- \\
\hline 362234100075201 & Li-0567 & 03-07-2012 & -- & -- & -- & -- & -- & -- & -- & -- & -- \\
\hline 362959100065801 & Li-0656 & 03-07-2012 & $<0.02$ & $<0.010$ & $<0.014$ & $<0.040$ & $<0.016$ & $<0.0056$ & $<0.021$ & $<0.010$ & $<0.016$ \\
\hline 355357101431901 & Mo-2351 & 02-28-2012 & $<0.02$ & $<0.010$ & $<0.014$ & $<0.040$ & $<0.016$ & $<0.0056$ & $<0.021$ & $<0.010$ & $<0.016$ \\
\hline 355810101574501 & Mo-2319 & 03-20-2013 & -- & -- & -- & -- & -- & -- & -- & -- & -- \\
\hline 360128101500001 & Mo-2389 & 02-29-2012 & -- & -- & -- & -- & -- & -- & -- & -- & -- \\
\hline 360307102071801 & Mo-2350 & $03-21-2013$ & -- & -- & -- & -- & -- & -- & -- & -- & -- \\
\hline 360416100445001 & Oc-4465 & $03-27-2013$ & -- & -- & -- & -- & -- & -- & -- & -- & -- \\
\hline 361631100444801 & Oc-1291 & $03-27-2013$ & -- & -- & -- & -- & -- & -- & -- & -- & -- \\
\hline 362146100542801 & Oc-4196 & 03-08-2012 & -- & -- & -- & -- & -- & -- & -- & -- & -- \\
\hline 360546101393301 & Sh-2366 & 03-01-2012 & -- & -- & -- & -- & -- & -- & -- & -- & -- \\
\hline 360640101434901 & Sh-2369 & 03-01-2012 & $<0.02$ & $<0.0100$ & $<0.014$ & $<0.040$ & $<0.016$ & $<0.0056$ & $<0.021$ & $<0.010$ & $<0.016$ \\
\hline 362019102035301 & Sh-4136 & 03-26-2013 & -- & -- & -- & -- & -- & -- & -- & -- & -- \\
\hline 362035101592801 & Sh-3719 & $03-26-2013$ & -- & -- & -- & -- & -- & -- & -- & -- & -- \\
\hline
\end{tabular}


Appendix 1. Physical properties and water-quality constituent concentrations measured in environmental samples collected from 30 monitor wells completed in the North Plains Groundwater Conservation District, Texas Panhandle, 2012-13.—Continued

[USGS, U.S. Geological Survey; NPGCD, North Plains Groundwater Conservation District; mg/L, milligrams per liter; $\mu$ S/cm, microsiemens per centimeter; nm, nanometer; +/-, plus or minus; NTRU, nephelometric turbidity ratio unit; $\mathrm{CaCO}_{3}$, calcium carbonate; $\mathrm{SiO}_{2}$, silicon dioxide; $\mathrm{N}$, nitrogen; P, phosphorus; +, plus; $\mu \mathrm{g} / \mathrm{L}$, micrograms per liter; CIAT, 2-Chloro-4-isopropylamino-6-amino-s-triazine; AMPA, Aminomethylphosphonic Acid; DCPA, Dacthal; EPTC, S-Ethyl dipropylthiocarbamate; E, estimated; <, less than; --, no data; n, less than the laboratory reporting level (LRL) and greater than or equal to the long-term method detection level (LT-MDL)]

\begin{tabular}{|c|c|c|c|c|c|c|c|c|c|c|c|}
\hline $\begin{array}{l}\text { USGS station } \\
\text { number }\end{array}$ & $\begin{array}{c}\text { NPGCD } \\
\text { county } \\
\text { well } \\
\text { identifier } \\
\text { (figs. 1, 3, } \\
5,6 \text {, and 8) }\end{array}$ & Date & $\begin{array}{l}\text { Fenamiphos } \\
\text { sulfone, } \\
\text { water, } \\
\text { filtered, } \\
\text { recoverable } \\
\text { ( } \mathrm{gg} / \mathrm{L} \text { ) }\end{array}$ & $\begin{array}{l}\text { Fenamiphos } \\
\text { sulfoxide, } \\
\text { water, } \\
\text { filtered, } \\
\text { recoverable } \\
\text { ( } \mathrm{gg} / \mathrm{L} \text { ) }\end{array}$ & $\begin{array}{l}\text { Fenamiphos, } \\
\text { water, } \\
\text { filtered, } \\
\text { recoverable } \\
\text { ( } \mu \mathrm{g} / \mathrm{L})\end{array}$ & $\begin{array}{c}\text { Fipronil } \\
\text { sulfide, } \\
\text { water, } \\
\text { filtered, } \\
\text { recoverable } \\
\text { ( } \mu \mathrm{g} / \mathrm{L})\end{array}$ & $\begin{array}{c}\text { Fipronil } \\
\text { sulfone, } \\
\text { water, } \\
\text { filtered, } \\
\text { recoverable } \\
\text { ( } \mathrm{gg} / \mathrm{L} \text { ) }\end{array}$ & $\begin{array}{c}\text { Fipronil, } \\
\text { water, } \\
\text { filtered, } \\
\text { recoverable } \\
\text { ( } \mu \mathrm{g} / \mathrm{L})\end{array}$ & $\begin{array}{c}\text { Flufenacet } \\
\text { oxanilic } \\
\text { acid, water, } \\
\text { filtered, } \\
\text { recoverable } \\
\text { ( } \mu \mathrm{g} / \mathrm{L})\end{array}$ & $\begin{array}{l}\text { Flufenacet } \\
\text { sulfonic } \\
\text { acid, water, } \\
\text { filtered, } \\
\text { recoverable } \\
\text { ( } \mu \mathrm{g} / \mathrm{L})\end{array}$ & $\begin{array}{c}\text { Flufenacet, } \\
\text { water, } \\
\text { filtered, } \\
\text { recoverable } \\
\text { ( } \mu \mathrm{g} / \mathrm{L} \text { ) }\end{array}$ \\
\hline 360727102303101 & Da-3688 & $03-22-2013$ & -- & -- & -- & -- & -- & -- & -- & -- & -- \\
\hline 362137102533001 & Da-3588 & 03-03-2012 & -- & -- & -- & -- & -- & -- & -- & -- & -- \\
\hline 362308102132801 & Da-3209 & $03-26-2013$ & -- & -- & -- & -- & -- & -- & -- & -- & -- \\
\hline 362341102375101 & Da-3231 & 03-04-2012 & -- & -- & -- & -- & -- & -- & -- & -- & -- \\
\hline 362648102442201 & Da-3589 & 03-03-2012 & $<0.054$ & $<0.08$ & $<0.030$ & $<0.012$ & $<0.024$ & $<0.018$ & $<0.02$ & $<0.02$ & $<0.02$ \\
\hline 361242101341001 & Hn-1917 & 03-02-2012 & $<0.054$ & $<0.08$ & $<0.030$ & $<0.012$ & $<0.024$ & $<0.018$ & $<0.02$ & $<0.02$ & $<0.02$ \\
\hline 362700101083801 & Hn-3686 & 03-08-2012 & -- & -- & -- & -- & -- & -- & -- & -- & -- \\
\hline 354832102124701 & На-2480 & 03-04-2012 & $<0.054$ & $<0.08$ & $<0.030$ & $<0.012$ & $<0.024$ & $<0.018$ & $<0.02$ & $<0.02$ & $<0.02$ \\
\hline 354833102182901 & На-2470 & $03-22-2013$ & -- & -- & -- & -- & -- & -- & -- & -- & -- \\
\hline 355725102145501 & На-2583 & $03-21-2013$ & -- & -- & -- & -- & -- & -- & -- & -- & -- \\
\hline 355827102443501 & На-5066 & $03-29-2013$ & -- & -- & -- & -- & -- & -- & -- & -- & -- \\
\hline 360241102443401 & На-5065 & $03-23-2013$ & -- & -- & -- & -- & -- & -- & -- & -- & -- \\
\hline 354810101351501 & $\mathrm{Hu}-4871$ & $03-25-2013$ & -- & -- & -- & -- & -- & -- & -- & -- & -- \\
\hline 354919101285301 & Hu-4855 & $03-25-2013$ & -- & -- & -- & -- & -- & -- & -- & -- & -- \\
\hline 360332100101401 & Li-0582 & 03-05-2012 & -- & -- & -- & -- & -- & -- & -- & -- & -- \\
\hline 360743100161001 & Li-0613 & 03-06-2012 & -- & -- & -- & -- & -- & -- & -- & -- & -- \\
\hline 361813100054301 & Li-3687 & 03-06-2012 & -- & -- & -- & -- & -- & -- & -- & -- & -- \\
\hline 362234100075201 & Li-0567 & 03-07-2012 & -- & -- & -- & -- & -- & -- & -- & -- & -- \\
\hline 362959100065801 & Li-0656 & 03-07-2012 & $<0.054$ & $<0.08$ & $<0.030$ & $<0.012$ & $<0.024$ & $<0.018$ & $<0.02$ & $<0.02$ & $<0.02$ \\
\hline 355357101431901 & Mo-2351 & $02-28-2012$ & $<0.054$ & $<0.08$ & $<0.030$ & $<0.012$ & $<0.024$ & $<0.018$ & $<0.02$ & $<0.02$ & $<0.02$ \\
\hline 355810101574501 & Mo-2319 & $03-20-2013$ & -- & -- & -- & -- & -- & -- & -- & -- & -- \\
\hline 360128101500001 & Mo-2389 & $02-29-2012$ & -- & -- & -- & -- & -- & -- & -- & -- & -- \\
\hline 360307102071801 & Mo-2350 & $03-21-2013$ & -- & -- & -- & -- & -- & -- & -- & -- & -- \\
\hline 360416100445001 & Oc-4465 & $03-27-2013$ & -- & -- & -- & -- & -- & -- & -- & -- & -- \\
\hline 361631100444801 & Oc-1291 & $03-27-2013$ & -- & -- & -- & -- & -- & -- & -- & -- & -- \\
\hline 362146100542801 & Oc-4196 & 03-08-2012 & -- & -- & -- & -- & -- & -- & -- & -- & -- \\
\hline 360546101393301 & Sh-2366 & 03-01-2012 & -- & -- & -- & -- & -- & -- & -- & -- & -- \\
\hline 360640101434901 & Sh-2369 & 03-01-2012 & $<0.054$ & $<0.08$ & $<0.030$ & $<0.012$ & $<0.024$ & $<0.018$ & $<0.02$ & $<0.02$ & $<0.02$ \\
\hline 362019102035301 & Sh-4136 & $03-26-2013$ & -- & -- & -- & -- & -- & -- & -- & -- & -- \\
\hline 362035101592801 & Sh-3719 & 03-26-2013 & -- & -- & -- & -- & -- & -- & -- & -- & -- \\
\hline
\end{tabular}


Appendix 1. Physical properties and water-quality constituent concentrations measured in environmental samples collected from 30 monitor wells completed in the North Plains Groundwater Conservation District, Texas Panhandle, 2012-13.-Continued

[USGS, U.S. Geological Survey; NPGCD, North Plains Groundwater Conservation District; mg/L, milligrams per liter; $\mu$ S/cm, microsiemens per centimeter; nm, nanometer; +/-, plus or minus; NTRU, nephelometric turbidity ratio unit; $\mathrm{CaCO}_{3}$, calcium carbonate; $\mathrm{SiO}_{2}$, silicon dioxide; $\mathrm{N}$, nitrogen; $\mathrm{P}$, phosphorus; +, plus; $\mu \mathrm{g} / \mathrm{L}$, micrograms per liter; CIAT, 2-Chloro-4-isopropylamino-6-amino-s-triazine;

AMPA, Aminomethylphosphonic Acid; DCPA, Dacthal; EPTC, S-Ethyl dipropylthiocarbamate; E, estimated; <, less than; --, no data; n, less than the laboratory reporting level (LRL) and greater than or equal to the long-term method detection level (LT-MDL)]

\begin{tabular}{|c|c|c|c|c|c|c|c|c|c|c|c|}
\hline $\begin{array}{l}\text { USGS station } \\
\text { number }\end{array}$ & $\begin{array}{c}\text { NPGCD } \\
\text { county } \\
\text { well } \\
\text { identifier } \\
\text { (figs. 1, 3, } \\
\text { 5, 6, and 8) }\end{array}$ & Date & $\begin{array}{c}\text { Fonofos, } \\
\text { water, } \\
\text { filtered, } \\
\text { recoverable } \\
\text { ( } \mu \mathrm{g} / \mathrm{L})\end{array}$ & $\begin{array}{c}\text { Glypho- } \\
\text { sate, water, } \\
\text { filtered (0.7 } \\
\text { micron glass } \\
\text { fiber filter), } \\
\text { recoverable } \\
(\mu \mathrm{g} / \mathrm{L})\end{array}$ & $\begin{array}{c}\text { Glufosinate, } \\
\text { water, } \\
\text { filtered ( } 0.7 \\
\text { micron glass } \\
\text { fiber filter), } \\
\text { recoverable } \\
(\mu \mathrm{g} / \mathrm{L})\end{array}$ & $\begin{array}{l}\text { Hexazinone, } \\
\text { water, } \\
\text { filtered, } \\
\text { recoverable } \\
\text { ( } \mathrm{gg} / \mathrm{L})\end{array}$ & $\begin{array}{l}\text { Hydroxy- } \\
\text { acetochlor, } \\
\text { water, } \\
\text { filtered, } \\
\text { recoverable } \\
\text { ( } \mu \mathrm{g} / \mathrm{L})\end{array}$ & $\begin{array}{l}\text { Hydroxy- } \\
\text { alachlor, } \\
\text { water, } \\
\text { filtered, } \\
\text { recoverable } \\
\text { ( } \mu \mathrm{g} / \mathrm{L} \text { ) }\end{array}$ & $\begin{array}{l}\text { Hydroxy- } \\
\text { dimethenamid, } \\
\text { water, } \\
\text { filtered, } \\
\text { recoverable } \\
(\mu \mathrm{g} / \mathrm{L})\end{array}$ & $\begin{array}{l}\text { Hydroxy- } \\
\text { metolachlor, } \\
\text { water, } \\
\text { filtered, } \\
\text { recoverable } \\
\text { ( } \mathrm{gg} / \mathrm{L} \text { ) }\end{array}$ & $\begin{array}{l}\text { Iprodione, } \\
\text { water, } \\
\text { filtered, } \\
\text { recoverable } \\
\text { ( } \mu \mathrm{g} / \mathrm{L})\end{array}$ \\
\hline 360727102303101 & Da-3688 & $03-22-2013$ & -- & -- & -- & -- & -- & -- & -- & -- & -- \\
\hline 362137102533001 & Da-3588 & 03-03-2012 & -- & -- & -- & -- & -- & -- & -- & -- & -- \\
\hline 362308102132801 & Da-3209 & $03-26-2013$ & -- & -- & -- & -- & -- & -- & -- & -- & -- \\
\hline 362341102375101 & Da-3231 & 03-04-2012 & -- & -- & -- & -- & -- & -- & -- & -- & -- \\
\hline 362648102442201 & Da-3589 & 03-03-2012 & $<0.0048$ & $<0.02$ & $<0.02$ & $<0.012$ & $<0.02$ & $<0.02$ & $<0.02$ & $<0.02$ & $<0.014$ \\
\hline 361242101341001 & Hn-1917 & 03-02-2012 & $<0.0048$ & $<0.02$ & $<0.02$ & $<0.012$ & $<0.02$ & $<0.02$ & $<0.02$ & $<0.02$ & $<0.014$ \\
\hline 362700101083801 & Hn-3686 & 03-08-2012 & -- & -- & -- & -- & -- & -- & -- & -- & -- \\
\hline 354832102124701 & На-2480 & 03-04-2012 & $<0.0048$ & $<0.02$ & $<0.02$ & $<0.012$ & $<0.02$ & $<0.02$ & $<0.02$ & $<0.02$ & $<0.014$ \\
\hline 354833102182901 & На-2470 & $03-22-2013$ & -- & -- & -- & -- & -- & -- & -- & -- & -- \\
\hline 355725102145501 & На-2583 & $03-21-2013$ & -- & -- & -- & -- & -- & -- & -- & -- & -- \\
\hline 355827102443501 & На-5066 & 03-29-2013 & -- & -- & -- & -- & -- & -- & -- & -- & -- \\
\hline 360241102443401 & На-5065 & 03-23-2013 & -- & -- & -- & -- & -- & -- & -- & -- & -- \\
\hline 354810101351501 & Hu-4871 & $03-25-2013$ & -- & -- & -- & -- & -- & -- & -- & -- & -- \\
\hline 354919101285301 & Hu-4855 & $03-25-2013$ & -- & -- & -- & -- & -- & -- & -- & -- & -- \\
\hline 360332100101401 & Li-0582 & 03-05-2012 & -- & -- & -- & -- & -- & -- & -- & -- & -- \\
\hline 360743100161001 & Li-0613 & 03-06-2012 & -- & -- & -- & -- & -- & -- & -- & -- & -- \\
\hline 361813100054301 & Li-3687 & 03-06-2012 & -- & -- & -- & -- & -- & -- & -- & -- & -- \\
\hline 362234100075201 & Li-0567 & 03-07-2012 & -- & -- & -- & -- & -- & -- & -- & -- & -- \\
\hline 362959100065801 & Li-0656 & 03-07-2012 & $<0.0048$ & $<0.02$ & $<0.02$ & $<0.012$ & $<0.02$ & $<0.02$ & $<0.02$ & $<0.02$ & $<0.014$ \\
\hline 355357101431901 & Mo-2351 & 02-28-2012 & $<0.0048$ & $<0.02$ & $<0.02$ & $<0.012$ & $<0.02$ & $<0.02$ & $<0.02$ & $<0.02$ & $<0.014$ \\
\hline 355810101574501 & Mo-2319 & 03-20-2013 & -- & -- & -- & -- & -- & -- & -- & -- & -- \\
\hline 360128101500001 & Мo-2389 & 02-29-2012 & -- & -- & -- & -- & -- & -- & -- & -- & -- \\
\hline 360307102071801 & Mo-2350 & $03-21-2013$ & -- & -- & -- & -- & -- & -- & -- & -- & -- \\
\hline 360416100445001 & Oc-4465 & $03-27-2013$ & -- & -- & -- & -- & -- & -- & -- & -- & -- \\
\hline 361631100444801 & Oc-1291 & $03-27-2013$ & -- & -- & -- & -- & -- & -- & -- & -- & -- \\
\hline 362146100542801 & Oc-4196 & 03-08-2012 & -- & -- & -- & -- & -- & -- & -- & -- & -- \\
\hline 360546101393301 & Sh-2366 & 03-01-2012 & -- & -- & -- & -- & -- & -- & -- & -- & -- \\
\hline 360640101434901 & Sh-2369 & 03-01-2012 & $<0.0048$ & $<0.02$ & $<0.02$ & $<0.012$ & $<0.02$ & $<0.02$ & $<0.02$ & $<0.02$ & $<0.014$ \\
\hline 362019102035301 & Sh-4136 & 03-26-2013 & -- & -- & -- & -- & -- & -- & -- & -- & -- \\
\hline 362035101592801 & Sh-3719 & $03-26-2013$ & -- & -- & -- & -- & -- & -- & -- & -- & -- \\
\hline
\end{tabular}


Appendix 1. Physical properties and water-quality constituent concentrations measured in environmental samples collected from 30 monitor wells completed in the North Plains Groundwater Conservation District, Texas Panhandle, 2012-13.—Continued

[USGS, U.S. Geological Survey; NPGCD, North Plains Groundwater Conservation District; mg/L, milligrams per liter; $\mu$ S/cm, microsiemens per centimeter; nm, nanometer; +/-, plus or minus; NTRU, nephelometric turbidity ratio unit; $\mathrm{CaCO}_{3}$, calcium carbonate; $\mathrm{SiO}_{2}$, silicon dioxide; $\mathrm{N}$, nitrogen; P, phosphorus; +, plus; $\mu \mathrm{g} / \mathrm{L}$, micrograms per liter; CIAT, 2-Chloro-4-isopropylamino-6-amino-s-triazine; AMPA, Aminomethylphosphonic Acid; DCPA, Dacthal; EPTC, S-Ethyl dipropylthiocarbamate; E, estimated; <, less than; --, no data; n, less than the laboratory reporting level (LRL) and greater than or equal to the long-term method detection level (LT-MDL)]

\begin{tabular}{|c|c|c|c|c|c|c|c|c|c|c|c|}
\hline $\begin{array}{l}\text { USGS station } \\
\text { number }\end{array}$ & $\begin{array}{c}\text { NPGCD } \\
\text { county } \\
\text { well } \\
\text { identifier } \\
\text { (figs. 1, 3, } \\
5,6 \text {, and 8) }\end{array}$ & Date & $\begin{array}{l}\text { Isofenphos, } \\
\text { water, } \\
\text { filtered, } \\
\text { recoverable } \\
\text { ( } \mu \mathrm{g} / \mathrm{L})\end{array}$ & $\begin{array}{c}\text { lambda- } \\
\text { Cyhalothrin, } \\
\text { water, } \\
\text { filtered, } \\
\text { recoverable } \\
\text { ( } \mu \mathrm{g} / \mathrm{L})\end{array}$ & $\begin{array}{l}\text { Malaoxon, } \\
\text { water, } \\
\text { filtered, } \\
\text { recoverable } \\
\text { ( } \mu \mathrm{g} / \mathrm{L})\end{array}$ & $\begin{array}{l}\text { Malathion, } \\
\text { water, } \\
\text { filtered, } \\
\text { recoverable } \\
\text { ( } \mu \mathrm{g} / \mathrm{L})\end{array}$ & $\begin{array}{l}\text { Metalaxyl, } \\
\text { water, } \\
\text { filtered, } \\
\text { recoverable } \\
(\mu \mathrm{g} / \mathrm{L})\end{array}$ & $\begin{array}{l}\text { Methida- } \\
\text { thion, } \\
\text { water, } \\
\text { filtered, } \\
\text { recoverable } \\
\text { ( } \mu \mathrm{g} / \mathrm{L})\end{array}$ & $\begin{array}{c}\text { Methyl } \\
\text { paraoxon, } \\
\text { water, } \\
\text { filtered, } \\
\text { recoverable } \\
\text { ( } \mu \mathrm{g} / \mathrm{L} \text { ) }\end{array}$ & $\begin{array}{c}\text { Methyl } \\
\text { parathion, } \\
\text { water, } \\
\text { filtered (0.7 } \\
\text { micron glass } \\
\text { fiber filter), } \\
\text { recoverable } \\
\text { ( } \mu \mathrm{g} / \mathrm{L})\end{array}$ & $\begin{array}{c}\text { Metolachlor } \\
\text { oxanilic } \\
\text { acid, water, } \\
\text { filtered ( } 0.7 \\
\text { micron glass } \\
\text { fiber filter), } \\
\text { recoverable } \\
(\mu \mathrm{g} / \mathrm{L})\end{array}$ \\
\hline 360727102303101 & Da-3688 & $03-22-2013$ & -- & -- & -- & -- & -- & -- & -- & -- & -- \\
\hline 362137102533001 & Da-3588 & 03-03-2012 & -- & -- & -- & -- & -- & -- & -- & -- & -- \\
\hline 362308102132801 & Da-3209 & $03-26-2013$ & -- & -- & -- & -- & -- & -- & -- & -- & -- \\
\hline 362341102375101 & Da-3231 & 03-04-2012 & -- & -- & -- & -- & -- & -- & -- & -- & -- \\
\hline 362648102442201 & Da-3589 & 03-03-2012 & $<0.008$ & $<0.010$ & $<0.022$ & $<0.016$ & $<0.014$ & $<0.012$ & $<0.014$ & $<0.008$ & $<0.02$ \\
\hline 361242101341001 & Hn-1917 & 03-02-2012 & $<0.008$ & $<0.010$ & $<0.022$ & $<0.016$ & $<0.014$ & $<0.012$ & $<0.014$ & $<0.008$ & $<0.02$ \\
\hline 362700101083801 & Hn-3686 & 03-08-2012 & -- & -- & -- & -- & -- & -- & -- & -- & -- \\
\hline 354832102124701 & На-2480 & 03-04-2012 & $<0.008$ & $<0.010$ & $<0.022$ & $<0.016$ & $<0.014$ & $<0.012$ & $<0.014$ & $<0.008$ & $<0.02$ \\
\hline 354833102182901 & Ha-2470 & $03-22-2013$ & -- & -- & -- & -- & -- & -- & -- & -- & -- \\
\hline 355725102145501 & На-2583 & $03-21-2013$ & -- & -- & -- & -- & -- & -- & -- & -- & -- \\
\hline 355827102443501 & На-5066 & 03-29-2013 & -- & -- & -- & -- & -- & -- & -- & -- & -- \\
\hline 360241102443401 & На-5065 & $03-23-2013$ & -- & -- & -- & -- & -- & -- & -- & -- & -- \\
\hline 354810101351501 & Hu-4871 & $03-25-2013$ & -- & -- & -- & -- & -- & -- & -- & -- & -- \\
\hline 354919101285301 & $\mathrm{Hu}-4855$ & $03-25-2013$ & -- & -- & -- & -- & -- & -- & -- & -- & -- \\
\hline 360332100101401 & Li-0582 & 03-05-2012 & -- & -- & -- & -- & -- & -- & -- & -- & -- \\
\hline 360743100161001 & Li-0613 & 03-06-2012 & -- & -- & -- & -- & -- & -- & -- & -- & -- \\
\hline 361813100054301 & Li-3687 & 03-06-2012 & -- & -- & -- & -- & -- & -- & -- & -- & -- \\
\hline 362234100075201 & Li-0567 & 03-07-2012 & -- & -- & -- & -- & -- & -- & -- & -- & -- \\
\hline 362959100065801 & Li-0656 & 03-07-2012 & $<0.008$ & $<0.010$ & $<0.022$ & $<0.016$ & $<0.014$ & $<0.012$ & $<0.014$ & $<0.008$ & $<0.02$ \\
\hline 355357101431901 & Mo-2351 & $02-28-2012$ & $<0.008$ & $<0.010$ & $<0.022$ & $<0.016$ & $<0.014$ & $<0.012$ & $<0.014$ & $<0.008$ & $<0.02$ \\
\hline 355810101574501 & Мо-2319 & $03-20-2013$ & -- & -- & -- & -- & -- & -- & -- & -- & -- \\
\hline 360128101500001 & Мo-2389 & 02-29-2012 & -- & -- & -- & -- & -- & -- & -- & -- & -- \\
\hline 360307102071801 & Mo-2350 & $03-21-2013$ & -- & -- & -- & -- & -- & -- & -- & -- & -- \\
\hline 360416100445001 & Oc-4465 & $03-27-2013$ & -- & -- & -- & -- & -- & -- & -- & -- & -- \\
\hline 361631100444801 & Oc-1291 & $03-27-2013$ & -- & -- & -- & -- & -- & -- & -- & -- & -- \\
\hline 362146100542801 & Oc-4196 & 03-08-2012 & -- & -- & -- & -- & -- & -- & -- & -- & -- \\
\hline 360546101393301 & Sh-2366 & 03-01-2012 & -- & -- & -- & -- & -- & -- & -- & -- & -- \\
\hline 360640101434901 & Sh-2369 & 03-01-2012 & $<0.008$ & $<0.010$ & $<0.022$ & $<0.016$ & $<0.014$ & $<0.012$ & $<0.014$ & $<0.008$ & $<0.02$ \\
\hline 362019102035301 & Sh-4136 & $03-26-2013$ & -- & -- & -- & -- & -- & -- & -- & -- & -- \\
\hline 362035101592801 & Sh-3719 & $03-26-2013$ & -- & -- & -- & -- & -- & -- & -- & -- & -- \\
\hline
\end{tabular}


Appendix 1. Physical properties and water-quality constituent concentrations measured in environmental samples collected from 30 monitor wells completed in the North Plains Groundwater Conservation District, Texas Panhandle, 2012-13.-Continued

[USGS, U.S. Geological Survey; NPGCD, North Plains Groundwater Conservation District; mg/L, milligrams per liter; $\mu$ S/cm, microsiemens per centimeter; nm, nanometer; +/-, plus or minus; NTRU, nephelometric turbidity ratio unit; $\mathrm{CaCO}_{3}$, calcium carbonate; $\mathrm{SiO}_{2}$, silicon dioxide; $\mathrm{N}$, nitrogen; P, phosphorus; +, plus; $\mu \mathrm{g} / \mathrm{L}$, micrograms per liter; CIAT, 2-Chloro-4-isopropylamino-6-amino-s-triazine; AMPA, Aminomethylphosphonic Acid; DCPA, Dacthal; EPTC, S-Ethyl dipropylthiocarbamate; E, estimated; <, less than; --, no data; n, less than the laboratory reporting level (LRL) and greater than or equal to the long-term method detection level (LT-MDL)]

\begin{tabular}{|c|c|c|c|c|c|c|c|c|c|c|c|}
\hline $\begin{array}{c}\text { USGS station } \\
\text { number }\end{array}$ & $\begin{array}{c}\text { NPGCD } \\
\text { county } \\
\text { well } \\
\text { identifier } \\
\text { (figs. 1, 3, } \\
5,6 \text {, and 8) }\end{array}$ & Date & $\begin{array}{l}\text { Metolachlor } \\
\text { sulfonic } \\
\text { acid, water, } \\
\text { filtered ( } 0.7 \\
\text { micron glass } \\
\text { fiber filter), } \\
\text { recoverable } \\
(\mu \mathrm{g} / \mathrm{L})\end{array}$ & $\begin{array}{l}\text { Metolachlor, } \\
\text { water, } \\
\text { filtered, } \\
\text { recoverable } \\
\text { ( } \mu \mathrm{g} / \mathrm{L})\end{array}$ & $\begin{array}{l}\text { Metribuzin, } \\
\text { water, } \\
\text { filtered, } \\
\text { recoverable } \\
\text { ( } \mu \mathrm{g} / \mathrm{L})\end{array}$ & $\begin{array}{c}\text { Molinate, } \\
\text { water, } \\
\text { filtered (0.7 } \\
\text { micron glass } \\
\text { fiber filter), } \\
\text { recoverable } \\
(\mu \mathrm{g} / \mathrm{L})\end{array}$ & $\begin{array}{l}\text { Myclobutanil, } \\
\text { water, } \\
\text { filtered, } \\
\text { recoverable } \\
\text { ( } \mu \mathrm{g} / \mathrm{L})\end{array}$ & $\begin{array}{l}\text { Oxyfluorfen, } \\
\text { water, } \\
\text { filtered, } \\
\text { recoverable } \\
\text { ( } \mu \mathrm{g} / \mathrm{L})\end{array}$ & $\begin{array}{l}\text { Pendimethalin, } \\
\text { water, } \\
\text { filtered (0.7 } \\
\text { micron glass } \\
\text { fiber filter), } \\
\text { recoverable } \\
\text { ( } \mu \mathrm{g} / \mathrm{L})\end{array}$ & $\begin{array}{c}\text { Phorate } \\
\text { oxygen } \\
\text { analog, } \\
\text { water, } \\
\text { filtered, } \\
\text { recoverable } \\
(\mu \mathrm{g} / \mathrm{L})\end{array}$ & $\begin{array}{c}\text { Phorate, } \\
\text { water, } \\
\text { filtered } \\
\text { (0.7 micron } \\
\text { glass fiber } \\
\text { filter), } \\
\text { recoverable } \\
\text { ( } \mu \mathrm{g} / \mathrm{L} \text { ) }\end{array}$ \\
\hline 360727102303101 & Da-3688 & $03-22-2013$ & -- & -- & -- & -- & -- & -- & -- & -- & -- \\
\hline 362137102533001 & Da-3588 & 03-03-2012 & -- & -- & -- & -- & -- & -- & -- & -- & -- \\
\hline 362308102132801 & Da-3209 & $03-26-2013$ & -- & -- & -- & -- & -- & -- & -- & -- & -- \\
\hline 362341102375101 & Da-3231 & 03-04-2012 & -- & -- & -- & -- & -- & -- & -- & -- & -- \\
\hline 362648102442201 & Da-3589 & 03-03-2012 & $<0.02$ & $<0.020$ & $<0.012$ & $<0.0040$ & $<0.010$ & $<0.010$ & $<0.012$ & $<0.027$ & $<0.020$ \\
\hline 361242101341001 & Hn-1917 & $03-02-2012$ & $<0.02$ & $<0.020$ & $<0.012$ & $<0.0040$ & $<0.010$ & $<0.010$ & $<0.012$ & $<0.027$ & $<0.020$ \\
\hline 362700101083801 & Hn-3686 & 03-08-2012 & -- & -- & -- & -- & -- & -- & -- & -- & -- \\
\hline 354832102124701 & На-2480 & 03-04-2012 & $<0.02$ & $<0.020$ & $<0.012$ & $<0.0040$ & $<0.010$ & $<0.010$ & $<0.012$ & $<0.027$ & $<0.020$ \\
\hline 354833102182901 & На-2470 & $03-22-2013$ & -- & -- & -- & -- & -- & -- & -- & -- & -- \\
\hline 355725102145501 & На-2583 & $03-21-2013$ & -- & -- & -- & -- & -- & -- & -- & -- & -- \\
\hline 355827102443501 & На-5066 & $03-29-2013$ & -- & -- & -- & -- & -- & -- & -- & -- & -- \\
\hline 360241102443401 & На-5065 & $03-23-2013$ & -- & -- & -- & -- & -- & -- & -- & -- & -- \\
\hline 354810101351501 & $\mathrm{Hu}-4871$ & $03-25-2013$ & -- & -- & -- & -- & -- & -- & -- & -- & -- \\
\hline 354919101285301 & Hu-4855 & $03-25-2013$ & -- & -- & -- & -- & -- & -- & -- & -- & -- \\
\hline 360332100101401 & Li-0582 & $03-05-2012$ & -- & -- & -- & -- & -- & -- & -- & -- & -- \\
\hline 360743100161001 & Li-0613 & 03-06-2012 & -- & -- & -- & -- & -- & -- & -- & -- & -- \\
\hline 361813100054301 & Li-3687 & 03-06-2012 & -- & -- & -- & -- & -- & -- & -- & -- & -- \\
\hline 362234100075201 & Li-0567 & 03-07-2012 & -- & -- & -- & -- & -- & -- & -- & -- & -- \\
\hline 362959100065801 & Li-0656 & 03-07-2012 & $<0.02$ & $<0.020$ & $<0.012$ & $<0.0040$ & $<0.010$ & $<0.010$ & $<0.012$ & $<0.027$ & $<0.020$ \\
\hline 355357101431901 & Mo-2351 & $02-28-2012$ & $<0.02$ & $<0.020$ & $<0.012$ & $<0.0040$ & $<0.010$ & $<0.010$ & $<0.012$ & $<0.027$ & $<0.020$ \\
\hline 355810101574501 & Mo-2319 & $03-20-2013$ & -- & -- & -- & -- & -- & -- & -- & -- & -- \\
\hline 360128101500001 & Мо-2389 & $02-29-2012$ & -- & -- & -- & -- & -- & -- & -- & -- & -- \\
\hline 360307102071801 & Мo-2350 & $03-21-2013$ & -- & -- & -- & -- & -- & -- & -- & -- & -- \\
\hline 360416100445001 & Oc-4465 & $03-27-2013$ & -- & -- & -- & -- & -- & -- & -- & -- & -- \\
\hline 361631100444801 & Oc-1291 & $03-27-2013$ & -- & -- & -- & -- & -- & -- & -- & -- & -- \\
\hline 362146100542801 & Oc-4196 & 03-08-2012 & -- & -- & -- & -- & -- & -- & -- & -- & -- \\
\hline 360546101393301 & Sh-2366 & 03-01-2012 & -- & -- & -- & -- & -- & -- & -- & -- & -- \\
\hline 360640101434901 & Sh-2369 & 03-01-2012 & $<0.02$ & $<0.020$ & $<0.012$ & $<0.0040$ & $<0.010$ & $<0.010$ & $<0.012$ & $<0.027$ & $<0.020$ \\
\hline 362019102035301 & Sh-4136 & $03-26-2013$ & -- & -- & -- & -- & -- & -- & -- & -- & -- \\
\hline 362035101592801 & Sh-3719 & $03-26-2013$ & -- & -- & -- & -- & -- & -- & -- & -- & -- \\
\hline
\end{tabular}


Appendix 1. Physical properties and water-quality constituent concentrations measured in environmental samples collected from 30 monitor wells completed in the North Plains Groundwater Conservation District, Texas Panhandle, 2012-13.—Continued

[USGS, U.S. Geological Survey; NPGCD, North Plains Groundwater Conservation District; mg/L, milligrams per liter; $\mu$ S/cm, microsiemens per centimeter; nm, nanometer; +/-, plus or minus; NTRU, nephelometric turbidity ratio unit; $\mathrm{CaCO}_{3}$, calcium carbonate; $\mathrm{SiO}_{2}$, silicon dioxide; $\mathrm{N}$, nitrogen; $\mathrm{P}$, phosphorus; +, plus; $\mu \mathrm{g} / \mathrm{L}$, micrograms per liter; CIAT, 2-Chloro-4-isopropylamino-6-amino-s-triazine; AMPA, Aminomethylphosphonic Acid; DCPA, Dacthal; EPTC, S-Ethyl dipropylthiocarbamate; E, estimated; <, less than; --, no data; n, less than the laboratory reporting level (LRL) and greater than or equal to the long-term method detection level (LT-MDL)]

\begin{tabular}{|c|c|c|c|c|c|c|c|c|c|c|c|}
\hline $\begin{array}{l}\text { USGS station } \\
\text { number }\end{array}$ & $\begin{array}{c}\text { NPGCD } \\
\text { county } \\
\text { well } \\
\text { identifier } \\
\text { (figs. 1, } \\
3,5,6, \\
\text { and 8) }\end{array}$ & Date & $\begin{array}{l}\text { Phosmet } \\
\text { oxygen } \\
\text { analog, } \\
\text { water, } \\
\text { filtered, } \\
\text { recoverable } \\
\text { ( } \mu \mathrm{g} / \mathrm{L})\end{array}$ & $\begin{array}{c}\text { Phosmet, } \\
\text { water, } \\
\text { filtered, } \\
\text { recoverable } \\
\text { ( } \mu \mathrm{g} / \mathrm{L} \text { ) }\end{array}$ & $\begin{array}{l}\text { Prometon, } \\
\text { water, } \\
\text { filtered, } \\
\text { recoverable } \\
\text { ( } \mu \mathrm{g} / \mathrm{L})\end{array}$ & $\begin{array}{c}\text { Prometryn, } \\
\text { water, } \\
\text { filtered, } \\
\text { recoverable } \\
\text { ( } \mu \mathrm{g} / \mathrm{L})\end{array}$ & $\begin{array}{c}\text { Propachlor } \\
\text { oxanilic } \\
\text { acid, water, } \\
\text { filtered (0.7 } \\
\text { micron glass } \\
\text { fiber filter), } \\
\text { recoverable } \\
\text { ( } \mu \mathrm{g} / \mathrm{L})\end{array}$ & $\begin{array}{c}\text { Propachlor } \\
\text { sulfonic } \\
\text { acid, water, } \\
\text { filtered (0.7 } \\
\text { micron glass } \\
\text { fiber filter), } \\
\text { recoverable } \\
\text { ( } \mu \mathrm{g} / \mathrm{L} \text { ) }\end{array}$ & $\begin{array}{l}\text { Propachlor, } \\
\text { water, } \\
\text { filtered, } \\
\text { recoverable } \\
\text { ( } \mu \mathrm{g} / \mathrm{L})\end{array}$ & $\begin{array}{c}\text { Propanil, } \\
\text { water, } \\
\text { filtered ( } 0.7 \\
\text { micron glass } \\
\text { fiber filter), } \\
\text { recoverable } \\
\text { ( } \mu \mathrm{g} / \mathrm{L})\end{array}$ & $\begin{array}{c}\text { Propargite, } \\
\text { water, } \\
\text { filtered ( } 0.7 \\
\text { micron glass } \\
\text { fiber filter), } \\
\text { recoverable } \\
\text { ( } \mu \mathrm{g} / \mathrm{L})\end{array}$ \\
\hline 360727102303101 & Da-3688 & $03-22-2013$ & -- & -- & -- & -- & -- & -- & -- & -- & -- \\
\hline 362137102533001 & Da-3588 & 03-03-2012 & -- & -- & -- & -- & -- & -- & -- & -- & -- \\
\hline 362308102132801 & Da-3209 & $03-26-2013$ & -- & -- & -- & -- & -- & -- & -- & -- & -- \\
\hline 362341102375101 & Da-3231 & 03-04-2012 & -- & -- & -- & -- & -- & -- & -- & -- & -- \\
\hline 362648102442201 & Da-3589 & 03-03-2012 & $<0.0511$ & $<0.080$ & $<0.012$ & $<0.010$ & $<0.02$ & $<0.05$ & $<0.02$ & $<0.010$ & $<0.020$ \\
\hline 361242101341001 & Hn-1917 & 03-02-2012 & $<0.0511$ & $<0.080$ & $<0.012$ & $<0.010$ & $<0.02$ & $<0.05$ & $<0.02$ & $<0.010$ & $<0.020$ \\
\hline 362700101083801 & Hn-3686 & 03-08-2012 & -- & -- & -- & -- & -- & -- & -- & -- & -- \\
\hline 354832102124701 & На-2480 & 03-04-2012 & $<0.0511$ & $<0.080$ & $<0.012$ & $<0.010$ & $<0.02$ & $<0.05$ & $<0.02$ & $<0.010$ & $<0.020$ \\
\hline 354833102182901 & На-2470 & $03-22-2013$ & -- & -- & -- & -- & -- & -- & -- & -- & -- \\
\hline 355725102145501 & На-2583 & 03-21-2013 & -- & -- & -- & -- & -- & -- & -- & -- & -- \\
\hline 355827102443501 & На-5066 & 03-29-2013 & -- & -- & -- & -- & -- & -- & -- & -- & -- \\
\hline 360241102443401 & На-5065 & 03-23-2013 & -- & -- & -- & -- & -- & -- & -- & -- & -- \\
\hline 354810101351501 & Hu-4871 & $03-25-2013$ & -- & -- & -- & -- & -- & -- & -- & -- & -- \\
\hline 354919101285301 & $\mathrm{Hu}-4855$ & $03-25-2013$ & -- & -- & -- & -- & -- & -- & -- & -- & -- \\
\hline 360332100101401 & Li-0582 & 03-05-2012 & -- & -- & -- & -- & -- & -- & -- & -- & -- \\
\hline 360743100161001 & Li-0613 & 03-06-2012 & -- & -- & -- & -- & -- & -- & -- & -- & -- \\
\hline 361813100054301 & Li-3687 & 03-06-2012 & -- & -- & -- & -- & -- & -- & -- & -- & -- \\
\hline 362234100075201 & Li-0567 & 03-07-2012 & -- & -- & -- & -- & -- & -- & -- & -- & -- \\
\hline 362959100065801 & Li-0656 & 03-07-2012 & $<0.0511$ & $<0.080$ & $<0.012$ & $<0.010$ & $<0.02$ & $<0.05$ & $<0.02$ & $<0.010$ & $<0.020$ \\
\hline 355357101431901 & Mo-2351 & 02-28-2012 & $<0.0511$ & $<0.080$ & $<0.012$ & $<0.010$ & $<0.02$ & $<0.05$ & $<0.02$ & $<0.010$ & $<0.020$ \\
\hline 355810101574501 & Mo-2319 & 03-20-2013 & -- & -- & -- & -- & -- & -- & -- & -- & -- \\
\hline 360128101500001 & Mo-2389 & 02-29-2012 & -- & -- & -- & -- & -- & -- & -- & -- & -- \\
\hline 360307102071801 & Mo-2350 & 03-21-2013 & -- & -- & -- & -- & -- & -- & -- & -- & -- \\
\hline 360416100445001 & Oc-4465 & 03-27-2013 & -- & -- & -- & -- & -- & -- & -- & -- & -- \\
\hline 361631100444801 & Oc-1291 & $03-27-2013$ & -- & -- & -- & -- & -- & -- & -- & -- & -- \\
\hline 362146100542801 & Oc-4196 & 03-08-2012 & -- & -- & -- & -- & -- & -- & -- & -- & -- \\
\hline 360546101393301 & Sh-2366 & 03-01-2012 & -- & -- & -- & -- & -- & -- & -- & -- & -- \\
\hline 360640101434901 & Sh-2369 & 03-01-2012 & $<0.0511$ & $<0.080$ & $<0.012$ & $<0.010$ & $<0.02$ & $<0.05$ & $<0.02$ & $<0.010$ & $<0.020$ \\
\hline 362019102035301 & Sh-4136 & 03-26-2013 & -- & -- & -- & -- & -- & -- & -- & -- & -- \\
\hline 362035101592801 & Sh-3719 & 03-26-2013 & -- & -- & -- & -- & -- & -- & -- & -- & -- \\
\hline
\end{tabular}


Appendix 1. Physical properties and water-quality constituent concentrations measured in environmental samples collected from 30 monitor wells completed in the North Plains Groundwater Conservation District, Texas Panhandle, 2012-13.-Continued

[USGS, U.S. Geological Survey; NPGCD, North Plains Groundwater Conservation District; mg/L, milligrams per liter; $\mu$ S/cm, microsiemens per centimeter; nm, nanometer; +/-, plus or minus; NTRU, nephelometric turbidity ratio unit; $\mathrm{CaCO}_{3}$, calcium carbonate; $\mathrm{SiO}_{2}$, silicon dioxide; N, nitrogen; P, phosphorus; +, plus; $\mu \mathrm{g} / \mathrm{L}$, micrograms per liter; CIAT, 2-Chloro-4-isopropylamino-6-amino-s-triazine;

AMPA, Aminomethylphosphonic Acid; DCPA, Dacthal; EPTC, S-Ethyl dipropylthiocarbamate; E, estimated; <, less than; --, no data; n, less than the laboratory reporting level (LRL) and greater than or equa to the long-term method detection level (LT-MDL)]

\begin{tabular}{|c|c|c|c|c|c|c|c|c|c|}
\hline $\begin{array}{c}\text { USGS station } \\
\text { number }\end{array}$ & $\begin{array}{c}\text { NPGCD } \\
\text { county } \\
\text { well } \\
\text { identifier } \\
\text { (figs. 1, 3, } \\
5,6 \text {, and 8) }\end{array}$ & Date & $\begin{array}{c}\text { Propyzamide, } \\
\text { water, filtered } \\
\text { (0.7 micron glass } \\
\text { fiber filter), } \\
\text { recoverable } \\
(\mu \mathrm{g} / \mathrm{L})\end{array}$ & $\begin{array}{l}\text { sec-Alachlor } \\
\text { sulfonic } \\
\text { acid, water, } \\
\text { filtered, } \\
\text { recoverable } \\
\text { ( } \mathrm{gg} / \mathrm{L})\end{array}$ & $\begin{array}{c}\text { Simazine, } \\
\text { water, } \\
\text { filtered, } \\
\text { recoverable } \\
(\mu \mathrm{g} / \mathrm{L})\end{array}$ & $\begin{array}{c}\text { Tebuthiuron, } \\
\text { water, filtered } \\
\text { (0.7 micron } \\
\text { glass fiber filter), } \\
\text { recoverable } \\
\text { ( } \mu \mathrm{g} / \mathrm{L})\end{array}$ & $\begin{array}{l}\text { Tefluthrin, } \\
\text { water, } \\
\text { filtered, } \\
\text { recoverable } \\
\text { ( } \mu \mathrm{g} / \mathrm{L})\end{array}$ & $\begin{array}{c}\text { Terbufos } \\
\text { oxygen analog } \\
\text { sulfone, water, } \\
\text { filtered, } \\
\text { recoverable } \\
\text { ( } \mu \mathrm{g} / \mathrm{L})\end{array}$ & $\begin{array}{c}\text { Terbufos, } \\
\text { water, filtered } \\
\text { (0.7 micron glass } \\
\text { fiber filter), } \\
\text { recoverable } \\
(\mu \mathrm{g} / \mathrm{L})\end{array}$ \\
\hline 360727102303101 & Da-3688 & $03-22-2013$ & -- & -- & -- & -- & -- & -- & -- \\
\hline 362137102533001 & Da-3588 & 03-03-2012 & -- & -- & -- & -- & -- & -- & -- \\
\hline 362308102132801 & Da-3209 & $03-26-2013$ & -- & -- & -- & -- & -- & -- & -- \\
\hline 362341102375101 & Da-3231 & 03-04-2012 & -- & -- & -- & -- & -- & -- & -- \\
\hline 362648102442201 & Da-3589 & 03-03-2012 & $<0.0036$ & $<0.02$ & $<0.006$ & $<0.028$ & $<0.014$ & $<0.045$ & $<0.018$ \\
\hline 361242101341001 & Hn-1917 & 03-02-2012 & $<0.0036$ & $<0.02$ & $<0.006$ & $<0.028$ & $<0.014$ & $<0.045$ & $<0.018$ \\
\hline 362700101083801 & Hn-3686 & 03-08-2012 & -- & -- & -- & -- & -- & -- & -- \\
\hline 354832102124701 & На-2480 & 03-04-2012 & $<0.0036$ & $<0.02$ & $<0.006$ & n0.016 & $<0.014$ & $<0.045$ & $<0.018$ \\
\hline 354833102182901 & На-2470 & $03-22-2013$ & -- & -- & -- & -- & -- & -- & -- \\
\hline 355725102145501 & На-2583 & 03-21-2013 & -- & -- & -- & -- & -- & -- & -- \\
\hline 355827102443501 & На-5066 & $03-29-2013$ & -- & -- & -- & -- & -- & -- & -- \\
\hline 360241102443401 & На-5065 & $03-23-2013$ & -- & -- & -- & -- & -- & -- & -- \\
\hline 354810101351501 & Hu-4871 & $03-25-2013$ & -- & -- & -- & -- & -- & -- & -- \\
\hline 354919101285301 & $\mathrm{Hu}-4855$ & $03-25-2013$ & -- & -- & -- & -- & -- & -- & -- \\
\hline 360332100101401 & Li-0582 & 03-05-2012 & -- & -- & -- & -- & -- & -- & -- \\
\hline 360743100161001 & Li-0613 & 03-06-2012 & -- & -- & -- & -- & -- & -- & -- \\
\hline 361813100054301 & Li-3687 & 03-06-2012 & -- & -- & -- & -- & -- & -- & -- \\
\hline 362234100075201 & Li-0567 & 03-07-2012 & -- & -- & -- & -- & -- & -- & -- \\
\hline 362959100065801 & Li-0656 & 03-07-2012 & $<0.0036$ & $<0.02$ & $<0.006$ & $<0.028$ & $<0.014$ & $<0.045$ & $<0.018$ \\
\hline 355357101431901 & Mo-2351 & $02-28-2012$ & $<0.0036$ & $<0.02$ & $<0.006$ & $<0.028$ & $<0.014$ & $<0.045$ & $<0.018$ \\
\hline 355810101574501 & Mo-2319 & 03-20-2013 & -- & -- & -- & -- & -- & -- & -- \\
\hline 360128101500001 & Mo-2389 & 02-29-2012 & -- & -- & -- & -- & -- & -- & -- \\
\hline 360307102071801 & Mo-2350 & 03-21-2013 & -- & -- & -- & -- & -- & -- & -- \\
\hline 360416100445001 & Oc-4465 & $03-27-2013$ & -- & -- & -- & -- & -- & -- & -- \\
\hline 361631100444801 & Oc-1291 & $03-27-2013$ & -- & -- & -- & -- & -- & -- & -- \\
\hline 362146100542801 & Oc-4196 & 03-08-2012 & -- & -- & -- & -- & -- & -- & -- \\
\hline 360546101393301 & Sh-2366 & 03-01-2012 & -- & -- & -- & -- & -- & -- & -- \\
\hline 360640101434901 & Sh-2369 & 03-01-2012 & $<0.0036$ & $<0.02$ & $<0.006$ & $<0.028$ & $<0.014$ & $<0.045$ & $<0.018$ \\
\hline 362019102035301 & Sh-4136 & 03-26-2013 & -- & -- & -- & -- & -- & -- & -- \\
\hline 362035101592801 & Sh-3719 & 03-26-2013 & -- & -- & -- & -- & -- & -- & -- \\
\hline
\end{tabular}


Appendix 1. Physical properties and water-quality constituent concentrations measured in environmental samples collected from 30 monitor wells completed in the North Plains Groundwater Conservation District, Texas Panhandle, 2012-13.—Continued

[USGS, U.S. Geological Survey; NPGCD, North Plains Groundwater Conservation District; mg/L, milligrams per liter; $\mu$ S/cm, microsiemens per centimeter; nm, nanometer; +/-, plus or minus; NTRU, nephelometric turbidity ratio unit; $\mathrm{CaCO}_{3}$, calcium carbonate; $\mathrm{SiO}_{2}$, silicon dioxide; $\mathrm{N}$, nitrogen; P, phosphorus; +, plus; $\mu \mathrm{g} / \mathrm{L}$, micrograms per liter; CIAT, 2-Chloro-4-isopropylamino-6-amino-s-triazine; AMPA, Aminomethylphosphonic Acid; DCPA, Dacthal; EPTC, S-Ethyl dipropylthiocarbamate; E, estimated; <, less than; --, no data; n, less than the laboratory reporting level (LRL) and greater than or equal to the long-term method detection level (LT-MDL)]

\begin{tabular}{|c|c|c|c|c|c|c|c|c|c|}
\hline $\begin{array}{c}\text { USGS station } \\
\text { number }\end{array}$ & $\begin{array}{c}\text { NPGCD } \\
\text { county } \\
\text { well } \\
\text { identifier } \\
\text { (figs. 1, 3, } \\
5,6 \text {, and 8) } \\
\end{array}$ & Date & $\begin{array}{c}\text { Terbuthylazine, } \\
\text { water, } \\
\text { filtered, } \\
\text { recoverable } \\
(\mu \mathrm{g} / \mathrm{L})\end{array}$ & $\begin{array}{l}\text { Thiobencarb, } \\
\text { water, } \\
\text { filtered } \\
\text { (0.7 micron } \\
\text { glass fiber filter), } \\
\text { recoverable } \\
\mu \mathrm{g} / \mathrm{L} \text { ) }\end{array}$ & $\begin{array}{c}\text { trans- } \\
\text { Propiconazole, } \\
\text { water, } \\
\text { filtered, } \\
\text { recoverable } \\
\text { ( } \mu \mathrm{g} / \mathrm{L})\end{array}$ & $\begin{array}{l}\text { Tribuphos, } \\
\text { water, } \\
\text { filtered, } \\
\text { recoverable } \\
\text { ( } \mu \mathrm{g} / \mathrm{L} \text { ) }\end{array}$ & $\begin{array}{c}\text { Trifluralin, } \\
\text { water, filtered } \\
\text { (0.7 micron } \\
\text { glass fiber filter), } \\
\text { recoverable } \\
(\mu \mathrm{g} / \mathrm{L})\end{array}$ & $\begin{array}{c}\text { 2-Chloro-2',6'- } \\
\text { diethylacetanilide, } \\
\text { water, } \\
\text { filtered, } \\
\text { recoverable } \\
(\mu \mathrm{g} / \mathrm{L})\end{array}$ & $\begin{array}{c}\text { 2-Chloro-N- } \\
\text { (2-ethyl-6- } \\
\text { methylphenyl) } \\
\text { acetamide, } \\
\text { water, filtered, } \\
\text { recoverable } \\
(\mu \mathrm{g} / \mathrm{L}) \\
\end{array}$ \\
\hline 360727102303101 & Da-3688 & $03-22-2013$ & -- & -- & -- & -- & -- & -- & -- \\
\hline 362137102533001 & Da-3588 & 03-03-2012 & -- & -- & -- & -- & -- & -- & -- \\
\hline 362308102132801 & Da-3209 & $03-26-2013$ & -- & -- & -- & -- & -- & -- & -- \\
\hline 362341102375101 & Da-3231 & 03-04-2012 & -- & -- & -- & -- & -- & -- & -- \\
\hline 362648102442201 & Da-3589 & 03-03-2012 & $<0.008$ & $<0.016$ & $<0.018$ & $<0.018$ & $<0.018$ & $<0.02$ & $<0.02$ \\
\hline 361242101341001 & Hn-1917 & 03-02-2012 & $<0.008$ & $<0.016$ & $<0.018$ & $<0.018$ & $<0.018$ & $<0.02$ & $<0.02$ \\
\hline 362700101083801 & Hn-3686 & 03-08-2012 & -- & -- & -- & -- & -- & -- & -- \\
\hline 354832102124701 & На-2480 & 03-04-2012 & $<0.008$ & $<0.016$ & $<0.018$ & $<0.018$ & $<0.018$ & $<0.02$ & $<0.02$ \\
\hline 354833102182901 & На-2470 & $03-22-2013$ & -- & -- & -- & -- & -- & -- & -- \\
\hline 355725102145501 & На-2583 & $03-21-2013$ & -- & -- & -- & -- & -- & -- & -- \\
\hline 355827102443501 & На-5066 & 03-29-2013 & -- & -- & -- & -- & -- & -- & -- \\
\hline 360241102443401 & На-5065 & 03-23-2013 & -- & -- & -- & -- & -- & -- & -- \\
\hline 354810101351501 & $\mathrm{Hu}-4871$ & $03-25-2013$ & -- & -- & -- & -- & -- & -- & -- \\
\hline 354919101285301 & $\mathrm{Hu}-4855$ & $03-25-2013$ & -- & -- & -- & -- & -- & -- & -- \\
\hline 360332100101401 & Li-0582 & 03-05-2012 & -- & -- & -- & -- & -- & -- & -- \\
\hline 360743100161001 & Li-0613 & 03-06-2012 & -- & -- & -- & -- & -- & -- & -- \\
\hline 361813100054301 & Li-3687 & 03-06-2012 & -- & -- & -- & -- & -- & -- & -- \\
\hline 362234100075201 & Li-0567 & 03-07-2012 & -- & -- & -- & -- & -- & -- & -- \\
\hline 362959100065801 & Li-0656 & 03-07-2012 & $<0.008$ & $<0.016$ & $<0.018$ & $<0.018$ & $<0.018$ & $<0.02$ & $<0.02$ \\
\hline 355357101431901 & Mo-2351 & 02-28-2012 & $<0.008$ & $<0.016$ & $<0.018$ & $<0.018$ & $<0.018$ & $<0.02$ & $<0.02$ \\
\hline 355810101574501 & Mo-2319 & 03-20-2013 & -- & -- & -- & -- & -- & -- & -- \\
\hline 360128101500001 & Mo-2389 & 02-29-2012 & -- & -- & -- & -- & -- & -- & -- \\
\hline 360307102071801 & Mo-2350 & $03-21-2013$ & -- & -- & -- & -- & -- & -- & -- \\
\hline 360416100445001 & Oc-4465 & $03-27-2013$ & -- & -- & -- & -- & -- & -- & -- \\
\hline 361631100444801 & Oc-1291 & $03-27-2013$ & -- & -- & -- & -- & -- & -- & -- \\
\hline 362146100542801 & Oc-4196 & 03-08-2012 & -- & -- & -- & -- & -- & -- & -- \\
\hline 360546101393301 & Sh-2366 & 03-01-2012 & -- & -- & -- & -- & -- & -- & -- \\
\hline 360640101434901 & Sh-2369 & 03-01-2012 & $<0.008$ & $<0.016$ & $<0.018$ & $<0.018$ & $<0.018$ & $<0.02$ & $<0.02$ \\
\hline 362019102035301 & Sh-4136 & $03-26-2013$ & -- & -- & -- & -- & -- & -- & -- \\
\hline 362035101592801 & Sh-3719 & $03-26-2013$ & -- & -- & -- & -- & -- & -- & -- \\
\hline
\end{tabular}



Appendix 2. Analyses of replicates and relative percent differences determined from filtered water samples collected from three monitor wells in the North Plains Groundwater Conservation District, Texas Panhandle, 2012-13.

[USGS, U.S. Geological Survey; NPGCD, North Plains Groundwater Conservation District; RPD, relative percent difference; mg/L, milligrams per liter; \%, percent; $\mathrm{SiO}_{2}$, silicon dioxide; N, nitrogen; P, phosohorus; <, less than; NC, not computed; +, plus; $\mu \mathrm{g} / \mathrm{L}$, micrograms per liter; CIAT, 2-Chloro-4-isopropylamino-6-amino-s-triazine; AMPA, Aminomethyl-phosphonic Acid; DCPA, Dacthal; EPTC, S-Ethyl dipropylthiocarbamate]

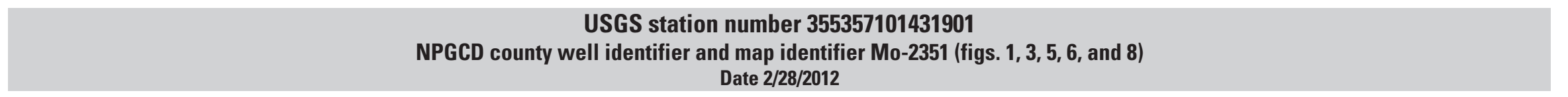

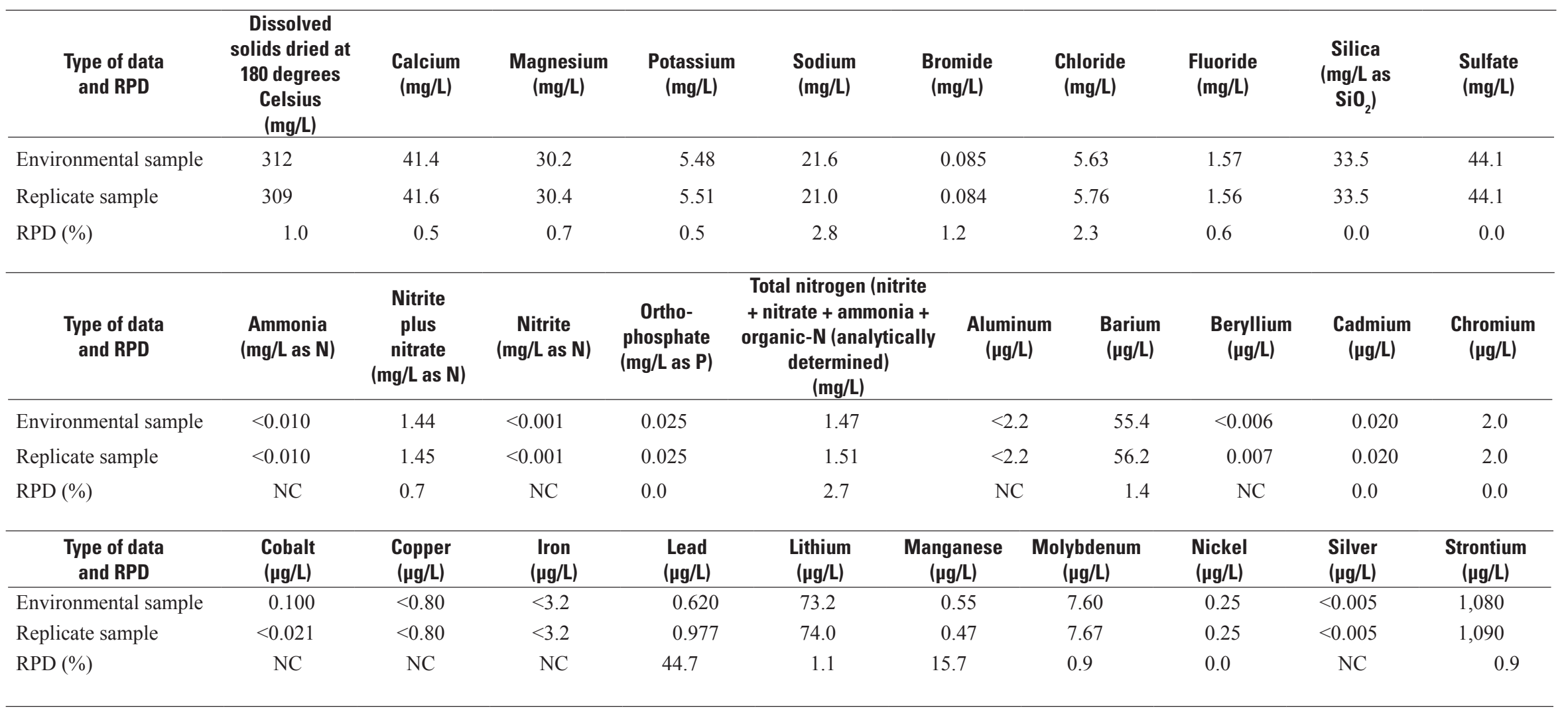

\begin{tabular}{|c|c|c|c|c|c|c|c|c|c|c|}
\hline $\begin{array}{l}\text { Type of data } \\
\text { and RPD }\end{array}$ & $\begin{array}{c}\text { Thallium } \\
\text { ( } \mu \mathrm{g} / \mathrm{L})\end{array}$ & $\begin{array}{l}\text { Vanadium } \\
(\mu \mathrm{g} / \mathrm{L})\end{array}$ & $\begin{array}{l}\text { Zinc } \\
(\mu \mathrm{g} / \mathrm{L})\end{array}$ & $\begin{array}{c}\text { Antimony } \\
(\mu \mathrm{g} / \mathrm{L})\end{array}$ & $\begin{array}{c}\text { Arsenic } \\
\text { ( } \mu \mathrm{g} / \mathrm{L})\end{array}$ & $\begin{array}{l}\text { Boron } \\
(\mu \mathrm{g} / \mathrm{L})\end{array}$ & $\begin{array}{l}\text { Selenium } \\
(\mu \mathrm{g} / \mathrm{L})\end{array}$ & $\begin{array}{c}\text { Uranium } \\
\text { ( } \mu \mathrm{g} / \mathrm{L})\end{array}$ & $\begin{array}{c}\text { 1-Naphthol } \\
(\mu \mathrm{g} / \mathrm{L})\end{array}$ & $\begin{array}{c}\text { 2,6-Diethyl- } \\
\text { aniline } \\
(\mu \mathrm{g} / \mathrm{L})\end{array}$ \\
\hline Environmental sample & $<0.010$ & 9.5 & 8.10 & 0.027 & 1.8 & 130 & 2.3 & 8.11 & $<0.0360$ & $<0.0060$ \\
\hline Replicate sample & $<0.010$ & 9.6 & 10.5 & $<0.027$ & 1.9 & 133 & 2.4 & 8.20 & $<0.0360$ & $<0.0060$ \\
\hline RPD (\%) & $\mathrm{NC}$ & 1.0 & 25.8 & $\mathrm{NC}$ & 5.4 & 2.3 & 4.3 & 1.1 & $\mathrm{NC}$ & $\mathrm{NC}$ \\
\hline
\end{tabular}


Appendix 2. Analyses of replicates and relative percent differences determined from filtered water samples collected from three monitor wells in the North Plains Groundwater Conservation District, Texas Panhandle, 2012-13.-Continued

[USGS, U.S. Geological Survey; NPGCD, North Plains Groundwater Conservation District; RPD, relative percent difference; mg/L, milligrams per liter; \%, percent; SiO, silicon dioxide; N, nitrogen; P, phosohorus; <, less than; NC, not computed; +, plus; $\mu \mathrm{g} / \mathrm{L}$, micrograms per liter; CIAT, 2-Chloro-4-isopropylamino-6-amino-s-triazine; AMPA, Aminomethyl-phosphonic Acid; DCPA, Dacthal; EPTC, S-Ethyl dipropylthiocarbamate]

\section{USGS station number 355357101431901 - Continued}

NPGCD county well identifier and map identifier Mo-2351 (figs. 1, 3, 5, 6, and 8) Date 2/28/2012

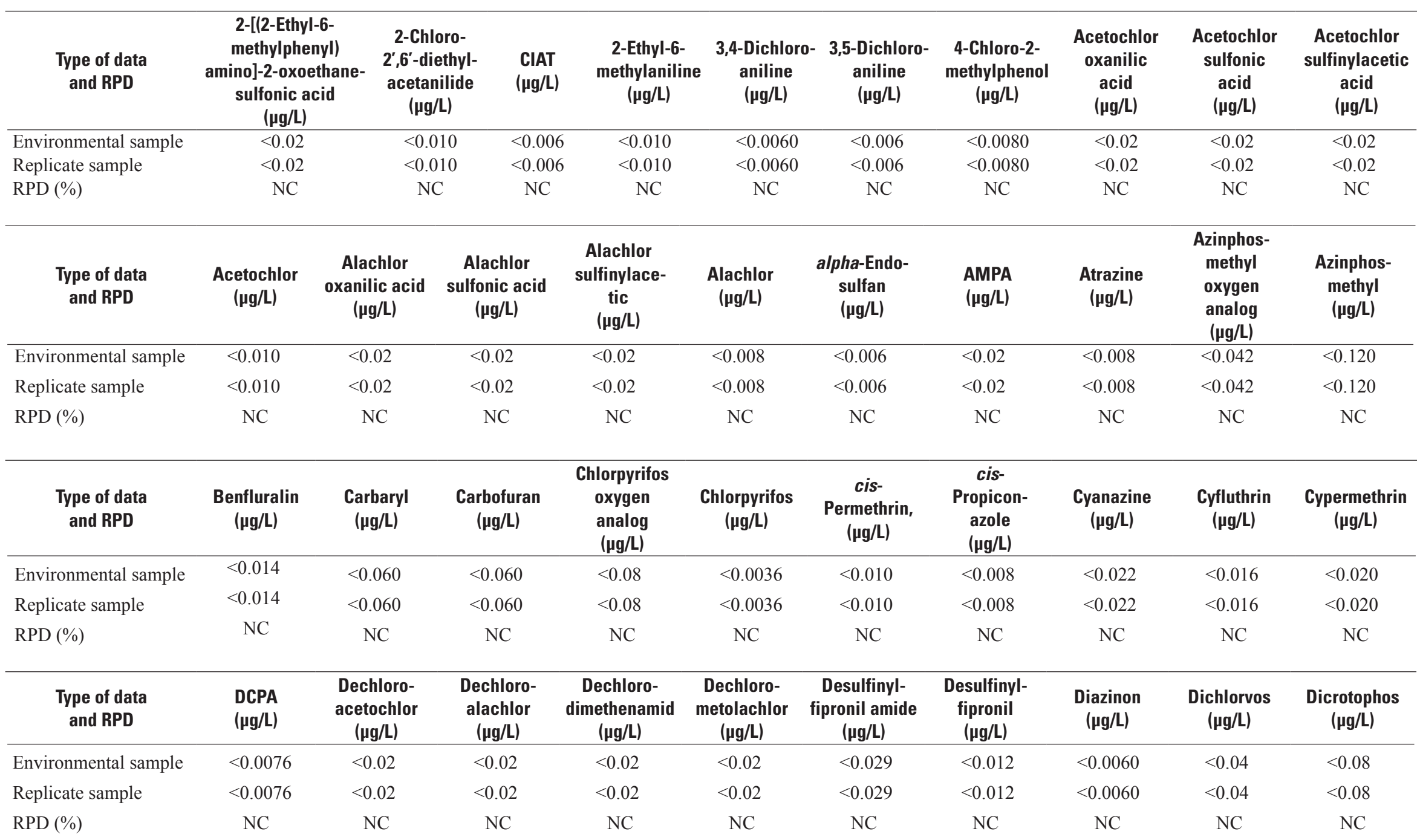


Appendix 2. Analyses of replicates and relative percent differences determined from filtered water samples collected from three monitor wells in the North Plains Groundwater Conservation District, Texas Panhandle, 2012-13.-Continued

[USGS, U.S. Geological Survey; NPGCD, North Plains Groundwater Conservation District; RPD, relative percent difference; mg/L, milligrams per liter; \%, percent; SiO, silicon dioxide; N, nitrogen; P, phosohorus; <, less than; NC, not computed; +, plus; $\mu \mathrm{g} / \mathrm{L}$, micrograms per liter; CIAT, 2-Chloro-4-isopropylamino-6-amino-s-triazine; AMPA, Aminomethyl-phosphonic Acid; DCPA, Dacthal; EPTC, S-Ethyl dipropylthiocarbamate]

\begin{tabular}{|c|c|c|c|c|c|c|c|c|c|c|}
\hline \multicolumn{11}{|c|}{$\begin{array}{l}\text { USGS station number } 355357101431901 \text {-Continued } \\
\text { NPGCD county well identifier and map identifier Mo-2351 (figs. 1, 3, 5, 6, and 8) } \\
\text { Date 2/28/2012 }\end{array}$} \\
\hline $\begin{array}{c}\text { Type of data } \\
\text { and RPD }\end{array}$ & $\begin{array}{c}\text { Dieldrin } \\
\text { ( } \mu \mathrm{g} / \mathrm{L})\end{array}$ & $\begin{array}{l}\text { Dimethena- } \\
\text { mid } \\
\text { oxanilic acid } \\
(\mu \mathrm{g} / \mathrm{L})\end{array}$ & $\begin{array}{l}\text { Dimethena- } \\
\text { mid } \\
\text { sulfonic acid } \\
(\mu \mathrm{g} / \mathrm{L})\end{array}$ & $\begin{array}{l}\text { Dimethe- } \\
\text { namid } \\
\text { ( } \mu \mathrm{g} / \mathrm{L})\end{array}$ & $\begin{array}{c}\text { Dimethoate } \\
\text { ( } \mu \mathrm{g} / \mathrm{L})\end{array}$ & $\begin{array}{l}\text { Disulfoton } \\
\text { sulfone } \\
(\mu \mathrm{g} / \mathrm{L})\end{array}$ & $\begin{array}{c}\text { Disulfoton } \\
(\mu \mathrm{g} / \mathrm{L})\end{array}$ & $\begin{array}{l}\text { Endosulfan } \\
\text { sulfate } \\
(\mu \mathrm{g} / \mathrm{L})\end{array}$ & $\begin{array}{l}\text { EPTC } \\
(\mu g / L)\end{array}$ & $\begin{array}{l}\text { Ethion } \\
\text { monoxon } \\
(\mu \mathrm{g} / \mathrm{L})\end{array}$ \\
\hline Environmental sample & $<0.008$ & $<0.02$ & $<0.02$ & $<0.02$ & $<0.0100$ & $<0.014$ & $<0.040$ & $<0.016$ & $<0.0056$ & $<0.021$ \\
\hline Replicate sample & $<0.008$ & $<0.02$ & $<0.02$ & $<0.02$ & $<0.0100$ & $<0.014$ & $<0.040$ & $<0.016$ & $<0.0056$ & $<0.021$ \\
\hline RPD (\%) & $\mathrm{NC}$ & $\mathrm{NC}$ & $\mathrm{NC}$ & $\mathrm{NC}$ & $\mathrm{NC}$ & $\mathrm{NC}$ & $\mathrm{NC}$ & $\mathrm{NC}$ & $\mathrm{NC}$ & $\mathrm{NC}$ \\
\hline $\begin{array}{c}\text { Type of data } \\
\text { and RPD }\end{array}$ & $\begin{array}{l}\text { Ethion } \\
(\mu \mathrm{g} / \mathrm{L})\end{array}$ & $\begin{array}{c}\text { Ethoprophos } \\
(\mu \mathrm{g} / \mathrm{L})\end{array}$ & $\begin{array}{l}\text { Fenamiphos } \\
\text { sulfone } \\
(\mu \mathrm{g} / \mathrm{L})\end{array}$ & $\begin{array}{l}\text { Fenamiphos } \\
\text { sulfoxide } \\
\text { ( } \mu \mathrm{g} / \mathrm{L})\end{array}$ & $\begin{array}{c}\text { Fenamiphos } \\
(\mu \mathrm{g} / \mathrm{L})\end{array}$ & $\begin{array}{l}\text { Fipronil } \\
\text { sulfide } \\
\text { ( } \mu \mathrm{g} / \mathrm{L})\end{array}$ & $\begin{array}{c}\text { Fipronil } \\
\text { sulfone } \\
\text { ( } \mu \mathrm{g} / \mathrm{L})\end{array}$ & $\begin{array}{c}\text { Fipronil } \\
\text { ( } \mu \mathrm{g} / \mathrm{L})\end{array}$ & $\begin{array}{c}\text { Flufenacet } \\
\text { oxanilic acid } \\
(\mu \mathrm{g} / \mathrm{L})\end{array}$ & $\begin{array}{c}\text { Flufenacet } \\
\text { sulfonic acid } \\
(\mu \mathrm{g} / \mathrm{L})\end{array}$ \\
\hline Environmental sample & $<0.010$ & $<0.016$ & $<0.054$ & $<0.08$ & $<0.030$ & $<0.012$ & $<0.024$ & $<0.018$ & $<0.02$ & $<0.02$ \\
\hline Replicate sample & $<0.010$ & $<0.016$ & $<0.054$ & $<0.08$ & $<0.030$ & $<0.012$ & $<0.024$ & $<0.018$ & $<0.02$ & $<0.02$ \\
\hline RPD (\%) & $\mathrm{NC}$ & $\mathrm{NC}$ & $\mathrm{NC}$ & $\mathrm{NC}$ & $\mathrm{NC}$ & $\mathrm{NC}$ & $\mathrm{NC}$ & $\mathrm{NC}$ & $\mathrm{NC}$ & $\mathrm{NC}$ \\
\hline $\begin{array}{c}\text { Type of data } \\
\text { and RPD }\end{array}$ & $\begin{array}{l}\text { Flufenacet } \\
(\mu \mathrm{g} / \mathrm{L})\end{array}$ & $\begin{array}{c}\text { Fonofos } \\
\text { ( } \mu \mathrm{g} / \mathrm{L})\end{array}$ & $\begin{array}{c}\text { Glyphosate } \\
\text { ( } \mu \mathrm{g} / \mathrm{L})\end{array}$ & $\begin{array}{c}\text { Glufosinate } \\
\text { ( } \mu \mathrm{g} / \mathrm{L})\end{array}$ & $\begin{array}{c}\text { Hexazinone } \\
(\mu \mathrm{g} / \mathrm{L})\end{array}$ & $\begin{array}{c}\text { Hydroxy- } \\
\text { acetochlor } \\
(\mu \mathrm{g} / \mathrm{L})\end{array}$ & $\begin{array}{c}\text { Hydroxy- } \\
\text { alachlor } \\
(\mu \mathrm{g} / \mathrm{L})\end{array}$ & $\begin{array}{c}\text { Hydroxy- } \\
\text { dimethenamid } \\
(\mu \mathrm{g} / \mathrm{L})\end{array}$ & $\begin{array}{c}\text { Hydroxy- } \\
\text { metolachlor } \\
(\mu \mathrm{g} / \mathrm{L})\end{array}$ & $\begin{array}{l}\text { Iprodione } \\
(\mu \mathrm{g} / \mathrm{L})\end{array}$ \\
\hline Environmental sample & $<0.02$ & $<0.0048$ & $<0.02$ & $<0.02$ & $<0.012$ & $<0.02$ & $<0.02$ & $<0.02$ & $<0.02$ & $<0.014$ \\
\hline Replicate sample & $<0.02$ & $<0.0048$ & $<0.02$ & $<0.02$ & $<0.012$ & $<0.02$ & $<0.02$ & $<0.02$ & $<0.02$ & $<0.014$ \\
\hline RPD (\%) & $\mathrm{NC}$ & $\mathrm{NC}$ & $\mathrm{NC}$ & $\mathrm{NC}$ & $\mathrm{NC}$ & $\mathrm{NC}$ & $\mathrm{NC}$ & $\mathrm{NC}$ & $\mathrm{NC}$ & $\mathrm{NC}$ \\
\hline $\begin{array}{c}\text { Type of data } \\
\text { and RPD }\end{array}$ & $\begin{array}{l}\text { Isofenphos } \\
(\mu \mathrm{g} / \mathrm{L})\end{array}$ & $\begin{array}{c}\text { lambda- } \\
\text { Cyhalothrin } \\
\text { ( } \mu \mathrm{g} / \mathrm{L})\end{array}$ & $\begin{array}{c}\text { Malaoxon } \\
(\mu \mathrm{g} / \mathrm{L})\end{array}$ & $\begin{array}{c}\text { Malathion } \\
(\mu \mathrm{g} / \mathrm{L})\end{array}$ & $\begin{array}{c}\text { Metalaxyl } \\
(\mu \mathrm{g} / \mathrm{L})\end{array}$ & $\begin{array}{l}\text { Methidathion } \\
(\mu \mathrm{g} / \mathrm{L})\end{array}$ & $\begin{array}{c}\text { Methyl } \\
\text { paraoxon } \\
(\mu \mathrm{g} / \mathrm{L})\end{array}$ & 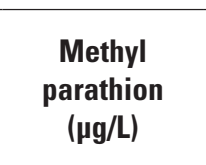 & $\begin{array}{c}\text { Metolachlor } \\
\text { oxanilic } \\
\text { acid } \\
(\mu \mathrm{g} / \mathrm{L})\end{array}$ & $\begin{array}{l}\text { Metolachlor } \\
\text { sulfonic } \\
\text { acid } \\
(\mu \mathrm{g} / \mathrm{L})\end{array}$ \\
\hline Environmental sample & $<0.008$ & $<0.010$ & $<0.022$ & $<0.016$ & $<0.014$ & $<0.012$ & $<0.014$ & $<0.008$ & $<0.02$ & $<0.02$ \\
\hline Replicate sample & $<0.008$ & $<0.010$ & $<0.022$ & $<0.016$ & $<0.014$ & $<0.012$ & $<0.014$ & $<0.008$ & $<0.02$ & $<0.02$ \\
\hline RPD (\%) & $\mathrm{NC}$ & $\mathrm{NC}$ & $\mathrm{NC}$ & $\mathrm{NC}$ & $\mathrm{NC}$ & $\mathrm{NC}$ & $\mathrm{NC}$ & $\mathrm{NC}$ & $\mathrm{NC}$ & $\mathrm{NC}$ \\
\hline
\end{tabular}


Appendix 2. Analyses of replicates and relative percent differences determined from filtered water samples collected from three monitor wells in the North Plains Groundwater Conservation District, Texas Panhandle, 2012-13.-Continued

[USGS, U.S. Geological Survey; NPGCD, North Plains Groundwater Conservation District; RPD, relative percent difference; mg/L, milligrams per liter; \%, percent; SiO P, phosohorus; <, less than; NC, not computed; +, plus; $\mu \mathrm{g} / \mathrm{L}$, micrograms per liter; CIAT, 2-Chloro-4-isopropylamino-6-amino-s-triazine; AMPA, Aminomethyl-phosphonic Acid; DCPA, Dacthal; EPTC, S-Ethyl dipropylthiocarbamate]

\section{USGS station number 355357101431901 - Continued}

NPGCD county well identifier and map identifier Mo-2351 (figs. 1, 3, 5, 6, and 8) Date 2/28/2012

\begin{tabular}{|c|c|c|c|c|c|c|c|c|c|c|c|c|}
\hline $\begin{array}{c}\text { Type of data } \\
\text { and RPD }\end{array}$ & $\begin{array}{c}\text { Metolachlor } \\
(\mu \mathrm{g} / \mathrm{L})\end{array}$ & $\begin{array}{c}\text { Metribuzin } \\
(\mu \mathrm{g} / \mathrm{L})\end{array}$ & $\begin{array}{l}\text { Molinate } \\
\text { ( } \mu \mathrm{g} / \mathrm{L})\end{array}$ & $\begin{array}{c}\text { Myclobutanil } \\
(\mu \mathrm{g} / \mathrm{L})\end{array}$ & \multicolumn{2}{|c|}{$\begin{array}{l}\text { Oxyfluorfen } \\
\text { ( } \mu \mathrm{g} / \mathrm{L})\end{array}$} & \multicolumn{2}{|c|}{$\begin{array}{c}\text { Pendi- } \\
\text { methalin } \\
(\mu \mathrm{g} / \mathrm{L})\end{array}$} & $\begin{array}{c}\text { Phorate } \\
\text { oxygen } \\
\text { analog } \\
(\mu \mathrm{g} / \mathrm{L})\end{array}$ & $\begin{array}{l}\text { Phorate } \\
\text { ( } \mu \mathrm{g} / \mathrm{L})\end{array}$ & $\begin{array}{c}\text { Phosmet } \\
\text { oxygen } \\
\text { analog } \\
(\mu \mathrm{g} / \mathrm{L})\end{array}$ & $\begin{array}{c}\text { Phosmet } \\
\text { ( } \mu \mathrm{g} / \mathrm{L})\end{array}$ \\
\hline Environmental sample & $<0.020$ & $<0.012$ & $<0.0040$ & $<0.010$ & \multicolumn{2}{|c|}{$<0.010$} & \multicolumn{2}{|c|}{$<0.012$} & $<0.027$ & $<0.020$ & $<0.0511$ & $<0.080$ \\
\hline Replicate sample & $<0.020$ & $<0.012$ & $<0.0040$ & $<0.010$ & \multicolumn{2}{|c|}{$<0.010$} & \multicolumn{2}{|c|}{$<0.012$} & $<0.027$ & $<0.020$ & $<0.0511$ & $<0.080$ \\
\hline RPD (\%) & $\mathrm{NC}$ & $\mathrm{NC}$ & $\mathrm{NC}$ & $\mathrm{NC}$ & \multicolumn{2}{|l|}{$\mathrm{NC}$} & \multicolumn{2}{|c|}{$\mathrm{NC}$} & $\mathrm{NC}$ & $\mathrm{NC}$ & $\mathrm{NC}$ & $\mathrm{NC}$ \\
\hline $\begin{array}{l}\text { Type of data } \\
\text { and RPD }\end{array}$ & $\begin{array}{l}\text { Prometon } \\
\text { ( } \mu \mathrm{g} / \mathrm{L})\end{array}$ & $\begin{array}{c}\text { Prometryn } \\
(\mu \mathrm{g} / \mathrm{L})\end{array}$ & $\begin{array}{c}\text { Propachlor } \\
\text { oxanilic } \\
\text { acid } \\
(\mu \mathrm{g} / \mathrm{L})\end{array}$ & $\begin{array}{l}\text { Propachlor } \\
\text { sulfonic } \\
\text { acid } \\
(\mu \mathrm{g} / \mathrm{L})\end{array}$ & \multicolumn{2}{|c|}{$\begin{array}{l}\text { Propachlor } \\
(\mu \mathrm{g} / \mathrm{L})\end{array}$} & \multicolumn{2}{|c|}{$\begin{array}{c}\text { Propanil } \\
\text { ( } \mu \mathrm{g} / \mathrm{L})\end{array}$} & $\begin{array}{l}\text { Propargite } \\
\text { ( } \mu \mathrm{g} / \mathrm{L})\end{array}$ & $\begin{array}{c}\text { Propyzamide } \\
\text { ( } \mu \mathrm{g} / \mathrm{L})\end{array}$ & $\begin{array}{c}\text { sec- } \\
\text { Alachlor } \\
\text { sulfonic } \\
\text { acid } \\
\text { ( } \mu \mathrm{g} / \mathrm{L})\end{array}$ & $\begin{array}{c}\text { Simazine } \\
(\mu \mathrm{g} / \mathrm{L})\end{array}$ \\
\hline Environmental sample & $<0.012$ & $<0.010$ & $<0.02$ & $<0.05$ & \multicolumn{2}{|c|}{$<0.02$} & \multicolumn{2}{|c|}{$<0.010$} & $<0.020$ & $<0.0036$ & $<0.02$ & $<0.006$ \\
\hline Replicate sample & $<0.012$ & $<0.010$ & $<0.02$ & $<0.05$ & \multicolumn{2}{|c|}{$<0.02$} & \multicolumn{2}{|c|}{$<0.010$} & $<0.020$ & $<0.0036$ & $<0.02$ & $<0.006$ \\
\hline RPD (\%) & $\mathrm{NC}$ & $\mathrm{NC}$ & $\mathrm{NC}$ & $\mathrm{NC}$ & $\mathrm{NC}$ & & \multicolumn{2}{|c|}{$\mathrm{NC}$} & $\mathrm{NC}$ & $\mathrm{NC}$ & $\mathrm{NC}$ & $\mathrm{NC}$ \\
\hline $\begin{array}{l}\text { Type of data } \\
\text { and RPD }\end{array}$ & $\begin{array}{l}\text { Tebuthiuron } \\
\text { ( } \mu \mathrm{g} / \mathrm{L})\end{array}$ & $\begin{array}{l}\text { Tefluthrin } \\
\text { ( } \mu \mathrm{g} / \mathrm{L})\end{array}$ & $\begin{array}{l}\text { Terbufos } \\
\text { oxygen } \\
\text { analog } \\
\text { sulfone } \\
\text { ( } \mu \mathrm{g} / \mathrm{L} \text { ) }\end{array}$ & $\begin{array}{c}\text { Terbufos } \\
\text { ( } \mu \mathrm{g} / \mathrm{L})\end{array}$ & $\begin{array}{l}\text { Terbuthyla- } \\
\text { zine } \\
(\mu \mathrm{g} / \mathrm{L})\end{array}$ & $\begin{array}{r}\text { Thiob } \\
\quad(\mu \mathrm{g}\end{array}$ & $\begin{array}{l}\text { icarb } \\
\text { L) }\end{array}$ & $\begin{array}{l}\text { trans- } \\
\text { Propicon- } \\
\text { azole } \\
\text { ( } \mu \mathrm{g} / \mathrm{L})\end{array}$ & $\begin{array}{c}\text { Tribuphos } \\
\text { ( } \mu \mathrm{g} / \mathrm{L})\end{array}$ & $\begin{array}{l}\text { Trifluralin } \\
\text { ( } \mu \mathrm{g} / \mathrm{L})\end{array}$ & $\begin{array}{c}\text { 2-Chloro- } \\
\text { 2',6'- } \\
\text { diethylacet- } \\
\text { anilide, } \\
\text { ( } \mu \mathrm{g} / \mathrm{L})\end{array}$ & $\begin{array}{l}\text { 2-Chloro-N- } \\
\text { (2-ethyl- } \\
\text { methylphe- } \\
\text { nyl) } \\
\text { acetamide } \\
(\mu \mathrm{g} / \mathrm{L})\end{array}$ \\
\hline Environmental sample & $<0.028$ & $<0.014$ & $<0.045$ & $<0.018$ & $<0.008$ & $<0$ & & $<0.018$ & $<0.018$ & $<0.018$ & $<0.02$ & $<0.02$ \\
\hline Replicate sample & $<0.028$ & $<0.014$ & $<0.045$ & $<0.018$ & $<0.008$ & $<0$. & & $<0.018$ & $<0.018$ & $<0.018$ & $<0.02$ & $<0.02$ \\
\hline RPD (\%) & $\mathrm{NC}$ & $\mathrm{NC}$ & $\mathrm{NC}$ & $\mathrm{NC}$ & $\mathrm{NC}$ & $\mathrm{N}$ & & $\mathrm{NC}$ & $\mathrm{NC}$ & $\mathrm{NC}$ & $\mathrm{NC}$ & $\mathrm{NC}$ \\
\hline
\end{tabular}


Appendix 2. Analyses of replicates and relative percent differences determined from filtered water samples collected from three monitor wells in the North Plains Groundwater Conservation District, Texas Panhandle, 2012-13.-Continued

[USGS, U.S. Geological Survey; NPGCD, North Plains Groundwater Conservation District; RPD, relative percent difference; mg/L, milligrams per liter; \%, percent; $\mathrm{SiO}_{2}$, silicon dioxide; N, nitrogen; P, phosohorus; <, less than; NC, not computed; +, plus; $\mu \mathrm{g} / \mathrm{L}$, micrograms per liter; CIAT, 2-Chloro-4-isopropylamino-6-amino-s-triazine; AMPA, Aminomethyl-phosphonic Acid; DCPA, Dacthal; EPTC, S-Ethyl dipropylthiocarbamate]

USGS station number 360332100101401
NPGCD county well identifier and map identifier Li-0582 (figs. 1, 3, 5, 6, and 8)
Date 3/5/2012

\begin{tabular}{|c|c|c|c|c|c|c|c|c|c|c|}
\hline $\begin{array}{c}\text { Type of data } \\
\text { and RPD }\end{array}$ & $\begin{array}{c}\text { Dissolved } \\
\text { solids dried at } \\
180 \text { degrees } \\
\text { Celsius } \\
\text { (mg/L) }\end{array}$ & $\begin{array}{c}\text { Calcium } \\
\text { (mg/L) }\end{array}$ & $\begin{array}{l}\text { Magnesium } \\
\text { (mg/L) }\end{array}$ & $\begin{array}{l}\text { Potassium } \\
\text { (mg/L) }\end{array}$ & $\begin{array}{l}\text { Sodium } \\
\text { (mg/L) }\end{array}$ & $\begin{array}{c}\text { Bromide } \\
\text { (mg/L) }\end{array}$ & $\begin{array}{c}\text { Chloride } \\
\text { (mg/L) }\end{array}$ & $\begin{array}{c}\text { Fluoride } \\
\text { (mg/L) }\end{array}$ & $\begin{array}{c}\text { Silica } \\
\left(\mathrm{mg} / \mathrm{L} \text { as } \mathrm{SiO}_{2}\right)\end{array}$ & $\begin{array}{l}\text { Sulfate } \\
(\mathrm{mg} / \mathrm{L})\end{array}$ \\
\hline Environmental sample & 258 & 52.1 & 14.6 & 2.85 & 16.2 & 0.070 & 4.28 & 0.32 & 33.7 & 6.10 \\
\hline Replicate sample & 259 & 51.2 & 14.4 & 2.95 & 16.5 & 0.070 & 4.27 & 0.30 & 33.7 & 6.14 \\
\hline RPD (\%) & 0.4 & 1.7 & 1.4 & 3.4 & 1.8 & 0.0 & 0.2 & 6.5 & 0.0 & 0.7 \\
\hline
\end{tabular}

\begin{tabular}{|c|c|c|c|c|c|c|c|c|c|c|}
\hline $\begin{array}{c}\text { Type of data } \\
\text { and RPD }\end{array}$ & $\begin{array}{c}\text { Ammonia } \\
\text { (mg/L as } N \text { ) }\end{array}$ & $\begin{array}{l}\text { Nitrite plus } \\
\text { nitrate } \\
\text { (mg/L as } \mathrm{N} \text { ) }\end{array}$ & $\begin{array}{c}\text { Nitrite } \\
\text { (mg/L as N) }\end{array}$ & $\begin{array}{c}\text { Ortho- } \\
\text { phosphate } \\
\text { (mg/L as } \mathrm{P} \text { ) }\end{array}$ & $\begin{array}{c}\text { Total nitrogen, } \\
\text { (nitrite + nitrate } \\
+ \text { ammonia + } \\
\text { organic-N) water, } \\
\text { filtered, analyti- } \\
\text { cally determined } \\
\text { (mg/L) }\end{array}$ & $\begin{array}{c}\text { Aluminum } \\
(\mu \mathrm{g} / \mathrm{L})\end{array}$ & $\begin{array}{l}\text { Barium } \\
\text { ( } \mu \mathrm{g} / \mathrm{L})\end{array}$ & $\begin{array}{c}\text { Beryllium } \\
\text { ( } \mu \mathrm{g} / \mathrm{L})\end{array}$ & $\begin{array}{c}\text { Cadmium } \\
(\mu \mathrm{g} / \mathrm{L})\end{array}$ & $\begin{array}{c}\text { Chromium } \\
\text { ( } \mu \mathrm{g} / \mathrm{L})\end{array}$ \\
\hline Environmental sample & $<0.010$ & 3.54 & $<0.001$ & 0.013 & 3.73 & $<2.2$ & 282 & $<0.006$ & $<0.016$ & 1.2 \\
\hline Replicate sample & $<0.010$ & 3.54 & $<0.001$ & 0.012 & 3.73 & $<2.2$ & 280 & $<0.006$ & $<0.016$ & 1.2 \\
\hline RPD (\%) & $\mathrm{NC}$ & 0.0 & $\mathrm{NC}$ & 8.0 & 0.0 & $\mathrm{NC}$ & 0.7 & $\mathrm{NC}$ & $\mathrm{NC}$ & 0.0 \\
\hline $\begin{array}{c}\text { Type of data } \\
\text { and RPD }\end{array}$ & $\begin{array}{l}\text { Cobalt } \\
(\mu \mathrm{g} / \mathrm{L})\end{array}$ & $\begin{array}{c}\text { Copper } \\
(\mu \mathrm{g} / \mathrm{L})\end{array}$ & $\begin{array}{c}\text { Iron } \\
(\mu \mathrm{g} / \mathrm{L})\end{array}$ & $\begin{array}{l}\text { Lead } \\
(\mu \mathrm{g} / \mathrm{L})\end{array}$ & $\begin{array}{c}\text { Lithium } \\
\text { ( } \mu \mathrm{g} / \mathrm{L} \text { ) }\end{array}$ & $\begin{array}{c}\text { Manganese } \\
(\mu \mathrm{g} / \mathrm{L})\end{array}$ & $\begin{array}{c}\text { Molybdenum } \\
\text { ( } \mu \mathrm{g} / \mathrm{L})\end{array}$ & $\begin{array}{c}\text { Nickel } \\
(\mu \mathrm{g} / \mathrm{L})\end{array}$ & $\begin{array}{l}\text { Silver } \\
(\mu \mathrm{g} / \mathrm{L})\end{array}$ & $\begin{array}{c}\text { Strontium } \\
(\mu \mathrm{g} / \mathrm{L})\end{array}$ \\
\hline Environmental sample & $<0.021$ & $<0.80$ & $<3.2$ & 0.476 & 20.8 & 0.46 & 0.286 & 0.30 & $<0.005$ & 652 \\
\hline Replicate sample & $<0.021$ & 1.2 & $<3.2$ & 0.855 & 21.2 & 0.46 & 0.281 & 0.30 & $<0.005$ & 653 \\
\hline RPD (\%) & $\mathrm{NC}$ & $\mathrm{NC}$ & $\mathrm{NC}$ & 56.9 & 1.9 & 0.0 & 1.8 & 0.0 & $\mathrm{NC}$ & 0.2 \\
\hline $\begin{array}{c}\text { Type of data } \\
\text { and RPD }\end{array}$ & $\begin{array}{c}\text { Thallium } \\
\text { ( } \mu \mathrm{g} / \mathrm{L})\end{array}$ & $\begin{array}{r}\text { Vana } \\
\text { ( } \mu \mathrm{g} \\
\end{array}$ & & $\begin{array}{c}\text { Zinc } \\
(\mu \mathrm{g} / \mathrm{L})\end{array}$ & $\begin{array}{c}\text { Antimony } \\
(\mu \mathrm{g} / \mathrm{L})\end{array}$ & $\begin{array}{c}\text { Arsenic } \\
(\mu \mathrm{g} / \mathrm{L})\end{array}$ & $\begin{array}{l}\text { Boron } \\
(\mu \mathrm{g} / \mathrm{L})\end{array}$ & \multicolumn{2}{|c|}{$\begin{array}{c}\text { Selenium } \\
(\mu \mathrm{g} / \mathrm{L})\end{array}$} & $\begin{array}{c}\text { Uranium } \\
(\mu \mathrm{g} / \mathrm{L})\end{array}$ \\
\hline Environmental sample & $<0.10$ & 8. & & 12.7 & 0.041 & 1.4 & 44 & \multicolumn{2}{|c|}{0.61} & 1.94 \\
\hline Replicate sample & $<0.10$ & 8. & & 13.3 & 0.046 & 1.3 & 44 & \multicolumn{2}{|c|}{0.60} & 1.95 \\
\hline RPD (\%) & $\mathrm{NC}$ & 1. & & 4.6 & 11.5 & 7.4 & 0.0 & \multicolumn{2}{|c|}{1.7} & 0.5 \\
\hline
\end{tabular}


Appendix 2. Analyses of replicates and relative percent differences determined from filtered water samples collected from three monitor wells in the North Plains Groundwater Conservation District, Texas Panhandle, 2012-13.-Continued

[USGS, U.S. Geological Survey; NPGCD, North Plains Groundwater Conservation District; RPD, relative percent difference; mg/L, milligrams per liter; \%, percent; SiO, silicon dioxide; N, nitrogen; P, phosohorus; <, less than; NC, not computed; +, plus; $\mu \mathrm{g} / \mathrm{L}$, micrograms per liter; CIAT, 2-Chloro-4-isopropylamino-6-amino-s-triazine; AMPA, Aminomethyl-phosphonic Acid; DCPA, Dacthal; EPTC, S-Ethyl dipropylthiocarbamate]

\section{USGS station number 355810101574501}

NPGCD county well identifier and map identifier Mo-2319 (figs. 1, 3, 5, 6, and 8) Date 3/20/2013

\begin{tabular}{|c|c|c|c|c|c|c|c|c|c|c|}
\hline $\begin{array}{c}\text { Type of data } \\
\text { and RPD }\end{array}$ & $\begin{array}{c}\text { Dissolved } \\
\text { solids dried } \\
\text { at } 180 \text { Celcius } \\
\text { (mg/L) }\end{array}$ & $\begin{array}{c}\text { Calcium } \\
\text { water, filtered } \\
\text { (mg/L) }\end{array}$ & $\begin{array}{l}\text { Magnesium } \\
\text { (mg/L) }\end{array}$ & $\begin{array}{l}\text { Potassium } \\
\text { (mg/L) }\end{array}$ & $\begin{array}{l}\text { Sodium } \\
\text { (mg/L) }\end{array}$ & $\begin{array}{l}\text { Bromide } \\
\text { (mg/L) }\end{array}$ & $\begin{array}{l}\text { Chloride } \\
\text { (mg/L) }\end{array}$ & $\begin{array}{c}\text { Fluoride } \\
\text { (mg/L) }\end{array}$ & $\begin{array}{c}\text { Silica } \\
\left(\mathrm{mg} / \mathrm{L} \text { as } \mathrm{SiO}_{2}\right)\end{array}$ & $\begin{array}{l}\text { Sulfate } \\
(\mathrm{mg} / \mathrm{L})\end{array}$ \\
\hline Environmental sample & 318 & 40.2 & 28.2 & 5.92 & 20.8 & 0.159 & 13.5 & 1.10 & 27.9 & 37.2 \\
\hline Replicate sample & 307 & 40.2 & 28.8 & 6.11 & 22.0 & 0.157 & 13.5 & 1.10 & 28.0 & 37.2 \\
\hline RPD (\%) & 3.5 & 0.0 & 2.1 & 3.2 & 5.6 & 1.3 & 0.0 & 0.0 & 0.4 & 0.0 \\
\hline $\begin{array}{c}\text { Type of data } \\
\text { and RPD }\end{array}$ & $\begin{array}{l}\text { Ammonia } \\
\text { (mg/L as N) }\end{array}$ & $\begin{array}{c}\text { Nitrite } \\
\text { plus } \\
\text { nitrate } \\
\text { (mg/L as N) }\end{array}$ & $\begin{array}{c}\text { Nitrite } \\
\text { (mg/L as N) }\end{array}$ & $\begin{array}{c}\text { Ortho- } \\
\text { phosphate } \\
\text { (mg/L as P) }\end{array}$ & $\begin{array}{c}\text { Total nitrogen, } \\
\text { (nitrite + nitrate } \\
\text { + ammonia + } \\
\text { organic-N) water, } \\
\text { filtered, analyti- } \\
\text { cally determined } \\
\text { (mg/L) }\end{array}$ & $\begin{array}{l}\text { Aluminum } \\
(\mu \mathrm{g} / \mathrm{L})\end{array}$ & $\begin{array}{c}\text { Barium } \\
\text { ( } \mu \mathrm{g} / \mathrm{L})\end{array}$ & $\begin{array}{l}\text { Beryllium } \\
\text { ( } \mu \mathrm{g} / \mathrm{L})\end{array}$ & $\begin{array}{c}\text { Cadmium } \\
(\mu \mathrm{g} / \mathrm{L})\end{array}$ & $\begin{array}{c}\text { Chromium } \\
\text { ( } \mu \mathrm{g} / \mathrm{L})\end{array}$ \\
\hline Environmental sample & $<0.010$ & 2.95 & $<0.001$ & 0.014 & 2.91 & $<2.2$ & 84.5 & $<0.006$ & 0.017 & 2.2 \\
\hline Replicate sample & $<0.010$ & 2.88 & $<0.001$ & 0.014 & 2.88 & $<2.2$ & 84.4 & $<0.006$ & $<0.016$ & 2.0 \\
\hline RPD (\%) & $\mathrm{NC}$ & 2.4 & $\mathrm{NC}$ & 0.0 & 1.0 & $\mathrm{NC}$ & 0.1 & $\mathrm{NC}$ & $\mathrm{NC}$ & 9.5 \\
\hline & $\begin{array}{l}\text { Cobalt } \\
(\mu \mathrm{g} / \mathrm{L})\end{array}$ & $\begin{array}{c}\text { Copper } \\
(\mu \mathrm{g} / \mathrm{L})\end{array}$ & $\begin{array}{l}\text { Iron } \\
(\mu \mathrm{g} / \mathrm{L})\end{array}$ & $\begin{array}{l}\text { Lead } \\
(\mu \mathrm{g} / \mathrm{L})\end{array}$ & $\begin{array}{c}\text { Lithium } \\
\text { ( } \mu \mathrm{g} / \mathrm{L})\end{array}$ & $\begin{array}{c}\text { Manganese } \\
(\mu \mathrm{g} / \mathrm{L})\end{array}$ & $\begin{array}{c}\text { Molybdenum } \\
\text { ( } \mu \mathrm{g} / \mathrm{L})\end{array}$ & $\begin{array}{c}\text { Nickel } \\
(\mu \mathrm{g} / \mathrm{L})\end{array}$ & $\begin{array}{l}\text { Silver } \\
(\mu \mathrm{g} / \mathrm{L})\end{array}$ & $\begin{array}{c}\text { Strontium } \\
(\mu \mathrm{g} / \mathrm{L})\end{array}$ \\
\hline Environmental sample & 0.059 & $<0.80$ & $<4.0$ & 0.208 & 39.3 & 0.35 & 5.88 & 0.33 & $<0.005$ & 1,070 \\
\hline Replicate sample & 0.025 & 0.92 & $<4.0$ & 0.190 & 46.0 & 0.21 & 5.53 & 0.22 & 0.006 & 1,100 \\
\hline RPD (\%) & 81.0 & $\mathrm{NC}$ & $\mathrm{NC}$ & 9.0 & 15.7 & 50.0 & 6.1 & 40.0 & $\mathrm{NC}$ & 2.8 \\
\hline $\begin{array}{c}\text { Type of data } \\
\text { and RPD }\end{array}$ & $\begin{array}{l}\text { Thallium } \\
\text { ( } \mu \mathrm{g} / \mathrm{L})\end{array}$ & \multicolumn{2}{|c|}{$\begin{array}{c}\text { Vanadium } \\
(\mu \mathrm{g} / \mathrm{L})\end{array}$} & $\begin{array}{c}\text { Zinc } \\
(\mu \mathrm{g} / \mathrm{L})\end{array}$ & $\begin{array}{c}\text { Antimony } \\
(\mu \mathrm{g} / \mathrm{L})\end{array}$ & $\begin{array}{c}\text { Arsenic } \\
\text { ( } \mu \mathrm{g} / \mathrm{L})\end{array}$ & $\begin{array}{l}\text { Boron } \\
(\mu \mathrm{g} / \mathrm{L})\end{array}$ & \multicolumn{2}{|c|}{$\begin{array}{c}\text { Selenium } \\
\text { ( } \mu \mathrm{g} / \mathrm{L})\end{array}$} & $\begin{array}{c}\text { Uranium } \\
\text { ( } \mu \mathrm{g} / \mathrm{L})\end{array}$ \\
\hline Environmental sample & $<0.010$ & \multicolumn{2}{|c|}{13.0} & 3.7 & 0.036 & 1.4 & 118 & \multicolumn{2}{|r|}{3.9} & 6.82 \\
\hline Replicate sample & $<0.010$ & \multicolumn{2}{|c|}{12.3} & 4.0 & $<0.027$ & 1.4 & 127 & \multicolumn{2}{|r|}{3.8} & 6.93 \\
\hline RPD (\%) & $\mathrm{NC}$ & \multicolumn{2}{|c|}{5.5} & 7.8 & $\mathrm{NC}$ & 0.0 & 7.4 & \multicolumn{2}{|r|}{2.6} & 1.6 \\
\hline
\end{tabular}


Publishing support provided by

Lafayette and Rolla Publishing Service Centers 
